
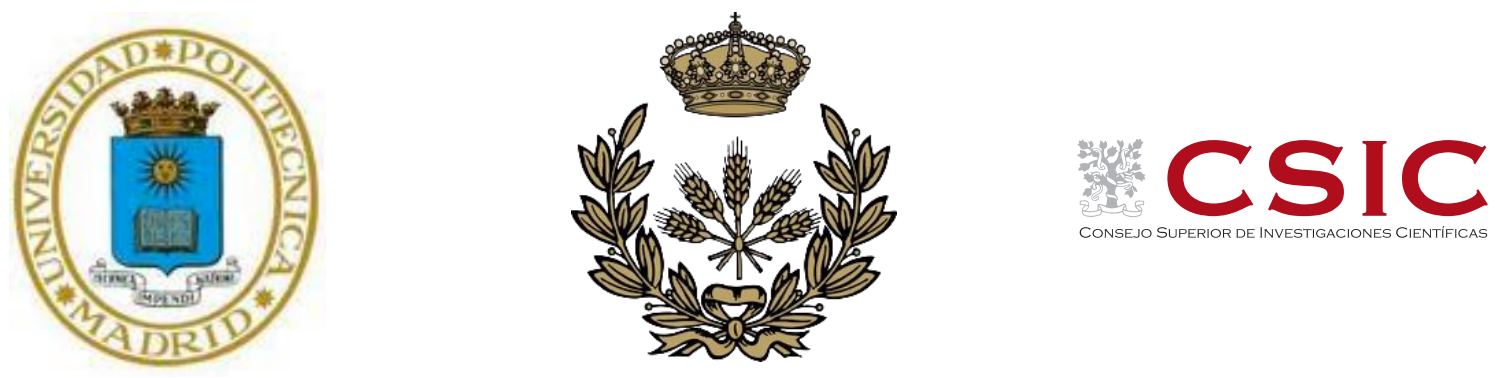

UNIVERSIDAD POLITÉCNICA DE MADRID

Escuela Técnica Superior de Ingeniería Agronómica, Alimentaria y de Biosistemas

\title{
IDENTIFICACIÓN Y REGULACIÓN DEL REPRESOR INMUNE BIR1 EN INTERACCIONES PLANTA-VIRUS
}

TESIS DOCTORAL

IRENE GUZMÁN BENITO

Licenciada en Biología 

DEPARTAMENTO DE BIOTECNOLOGÍA-BIOLOGÍA VEGETAL ESCUELA TÉCNICA SUPERIOR DE INGENIERÍA AGRONÓMICA, ALIMENTARIA Y DE BIOSISTEMAS

UNIVERSIDAD POLITÉCNICA DE MADRID

\section{IDENTIFICACIÓN Y REGULACIÓN DEL REPRESOR INMUNE BIR1 EN INTERACCIONES PLANTA-VIRUS \\ TESIS DOCTORAL}

IRENE GUZMÁN BENITO

Licenciada en Biología

Director de tesis:

CÉSAR LLAVE CORREAS

Doctor en Ciencias Biológicas 



\section{RECONOCIMIENTOS}

Esta tesis doctoral se ha realizado en el Departamento Biotecnología Microbiana y de Plantas del Centro de Investigaciones Biológicas del Consejo Superior de Investigaciones Científicas bajo la supervisión y dirección del Dr. César Llave Correas. A la realización del trabajo presentado han contribuido las siguientes personas:

El Dr. César Llave Correas (CIB, CSIC, Madrid) con su dirección, asesoramiento, formación teórica y práctica durante el desarrollo de la tesis.

La Dra. Livia Donaire (CIB, CSIC, Madrid) con la realización y análisis del "procesoma" y del degradoma.

La Dra. Livia Donaire y la Dra. Virginia Ruíz-Ferrer (CIB, CSIC, Madrid) con su asesoramiento y formación en las primeras etapas de la tesis.

El Dr. Andrzej T. Wierzbicki (MCDB, University of Michigan, USA) con la colaboración en la parte de metilación y la cesión de los datos del WGBS así como con su asesoramiento durante toda mi estancia en la Universidad de Michigan.

La Dra. Sonia Osorio y el Dr. José G. Vallarino (IHSM-UMA-CSIC, Málaga) con la realización del GC-TOF-MS para analizar la acumulación de ácido salicílico y ácido jasmónico en plantas infectadas.

El Dr. Vitor Amorim-Silva (IHSM-UMA-CSIC, Málaga) con la realización de la triple recombinación de las construcciones sobreexpresoras de BIR1 inducibles por dexametasona.

La Dra. Alicia Esteban (IHSM-UMA-CSIC, Málaga) con la toma de imágenes de microscopía confocal de las líneas transgénicas sobreexpresoras de BIR1.

El Dr. Yuelin Zhang (University of British Columbia, Canadá), el Dr. James C. Carrington (The Donald Danforth Plant Center, MO, USA), el Dr. Steve Jacobsen (UCLA-HHMI, USA), el Dr. Craig Pikaard (Indiana University, USA), el Dr. Eric Richards (Boyce Thompson Institute, Cornell University, USA) y el Dr. Xinniang Dong (Duke University, NC, USA) con la cesión de las semillas.

Montserrat Llorente (CIB, CSIC, Madrid) con su apoyo técnico en el laboratorio. 
Pablo Jalón del servicio de fotografía del CIB con la toma y tratamiento de imágenes.

Los servicios de esterilización y limpieza así como administración del CIB con su aportación práctica y resolutiva.

Al Ministerio de Economía y Competitividad, con la financiación para el desarrollo de esta tesis con una beca de Formación de Personal Investigador FPI (BES2013-063138), una ayuda a la movilidad predoctoral para la realización de Estancias Breves en centros de I+D (EEBB-I-16-10815) y los proyectos BIO2012-39973 y BIO2015-70752-R del Plan Nacional de Investigación del Ministerio de Economía y Competitividad (MINECO/FEDER). 


\section{ÍNDICE}

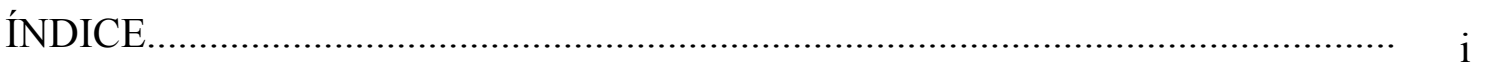

ÍNDICE DE FIGURAS.................................................................................. vii

ÍNDICE DE TABLAS...............................................................................

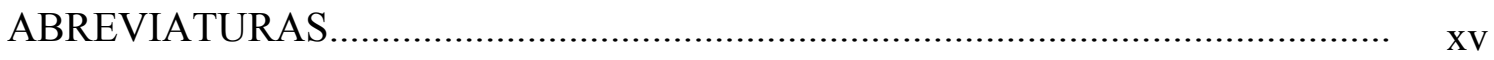

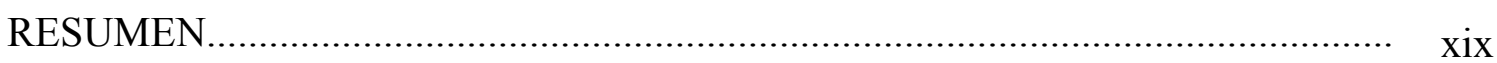

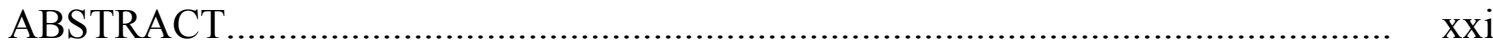

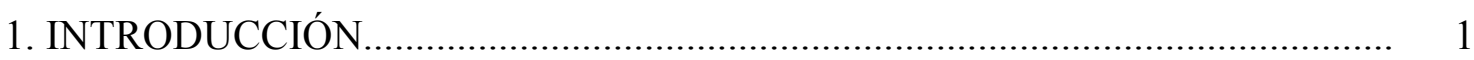

1.1. Inmunidad basal en plantas.............................................................................

1.1.1. La inmunidad basal en plantas: Mecanismos generales de acción............. 4

1.1.2. Vías de señalización en la respuesta inmune............................................... 5

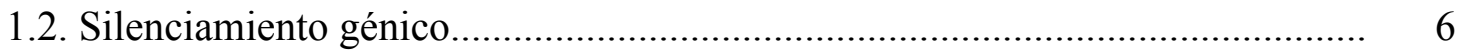

1.2.1. Mecanismos generales de acción e importancia biológica........................... 6

1.2.2. Bases moleculares del silenciamiento génico............................................. 6

1.2.3. Caracterización de los sRNAs endógenos................................................... 6

1.2.3.1. miRNAs....................................................................................

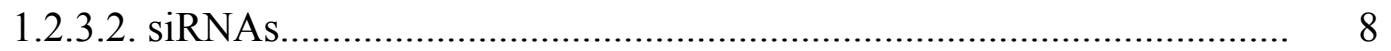

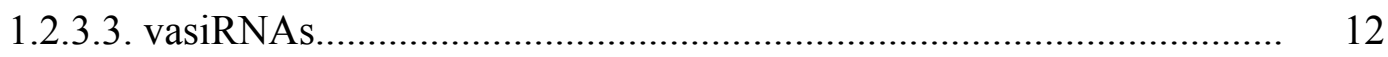

1.2.4. Proteínas implicadas en la biogénesis de sRNAs....................................... 13

1.2.4.1. Proteínas DCL..................................................................................... 13

1.2.4.2. Proteínas RDR........................................................................... 14

1.2.5. Proteínas implicadas en la actividad de los sRNAs.................................. 15

1.2.5.1. Proteínas AGO_................................................................................. 15

1.3. Mecanismos efectores de silenciamiento génico............................................... 16

1.3.1. Silenciamiento post-transcripcional........................................................... 16 
1.3.2. Silenciamiento transcripcional.............................................................. 17

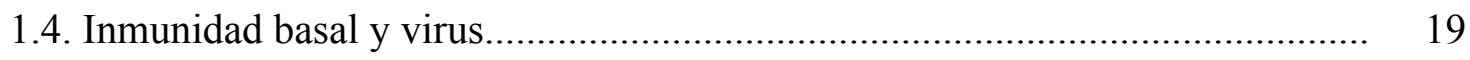

1.5. Mecanismos de silenciamiento génico y respuesta inmune............................... 20

1.5.1. Silenciamiento transcripcional y respuesta inmune.................................. 20

1.5.2. Silenciamiento post-transcripcional y respuesta inmune............................ 21

1.5.3. Silenciamiento génico inducido por virus.................................................. 23

1.5.4. Silenciamiento génico como mecanismo antiviral en plantas..................... 23

1.5.5. Supresión del silenciamiento génico antiviral........................................... 26

1.6. Regulación de la respuesta inmune en las infecciones virales............................ 26

1.7. Posibles mecanismos de activación de la inmunidad basal durante la 27

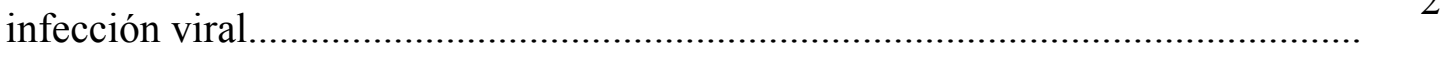

1.8. Infecciones virales y senescencia en plantas................................................... 28

1.9. Antecedentes y resultados previos................................................................ $\quad 30$

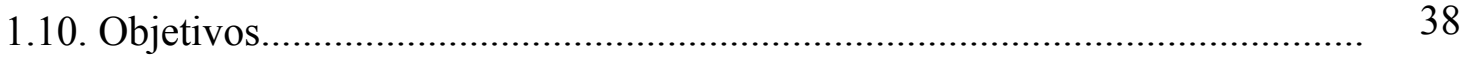

2. MATERIALES Y MÉTODOS ...................................................................... 41

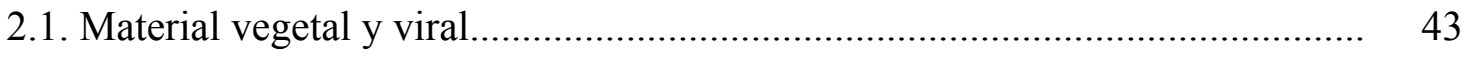

2.1.1. Material vegetal y condiciones de crecimiento........................................... 43

2.1.2. Construcción de plantas transgénicas......................................................... 44

2.1.3. Aislados virales................................................................................... 45

2.2. Expresión transitoria, inoculación viral y tratamientos vegetales........................ 46

2.2.1. Expresión transitoria en $N$. benthamiana ................................................ 46

2.2.2. Inoculación de virus............................................................................ 46

2.2.3. Aplicación de DEX en plantas de Arabidopsis......................................... 47

2.2.4. Aplicación de SA y determinación de los niveles de SA........................... 47 
2.2.5. Preparación de protoplastos y transfección............................................ 48

2.3. Purificación y análisis de DNA........................................................................ 48

2.3.1. Purificación de DNA genómico................................................................ 48

2.3.2. Purificación de DNA plasmídico.......................................................... 48

2.3.3. Transcripción Inversa...................................................................... 48

2.3.4. Amplificación de DNA mediante PCR ..................................................... 48

2.3.5. Electroforesis en gel de agarosa.......................................................... 49

2.3.6. Purificación de fragmentos de PCR....................................................... 49

2.3.7. Marcaje radioactivo de sondas.......................................................... 49

2.3.8. Análisis de metilación............................................................................. 49

2.3.9. Identificación de puntos de unión de TF................................................. 50

2.4. Purificación y análisis de RNA................................................................ $\quad 50$

2.4.1. Purificación de RNA total.......................................................................... 50

2.4.2. Northern blot..................................................................................... 51

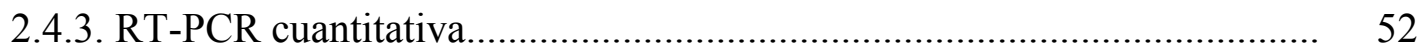

2.4.4. 5' RACE (rapid amplification of cDNA ends)..................................... 52

2.4.5. Genotecas de sRNAs y de degradoma.................................................. 53

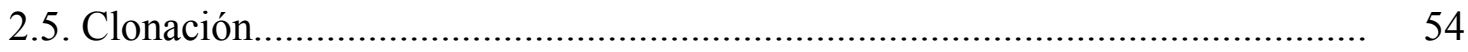

2.5.1. Plásmidos base ................................................................................... 54

2.5.2. Otras construcciones......................................................................... $\quad 55$

2.5.3. Clonación con enzimas de restricción................................................... 56

2.5.4. Clonación con sistema GATEWAY ........................................................ 56

2.5.5. Mutagénesis dirigida por PCR ............................................................. 57

2.5.6. Mantenimiento de clones.................................................................... 5

2.6. Análisis de proteínas................................................................................ 58 
2.6.1. Purificación de proteínas................................................................. 58

2.6.2. Western blot.................................................................................... 58

2.6.3. Estudio de localización subcelular mediante microscopía laser confocal.. $\quad 59$

2.6.4. Tinción histoquímica de GUS........................................................... 59

2.6.5. Tinción con azul de tripano........................................................... 59

2.7. Bases de datos y análisis estadístico....................................................... 59

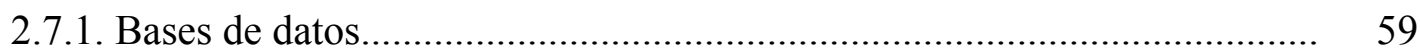

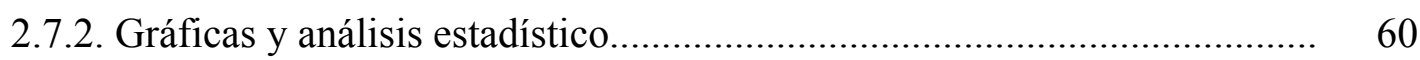

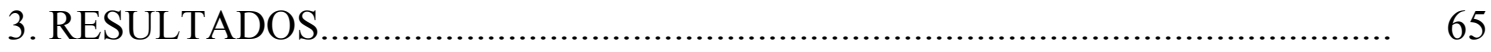

3.1. Análisis de la expresión de $B I R l$ en plantas infectadas con virus.................... 65

3.2. Efecto de la muerte celular y de la defensa mediada por SA en la resistencia antiviral de los mutantes birl-1.

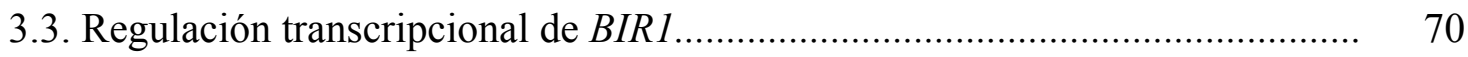

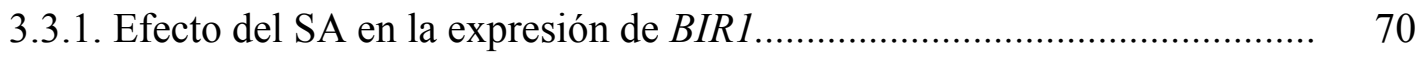

3.3.2. Efecto de la metilación de DNA mediada por RNA (RdDM) en la regulación transcripcional de $B I R I$.

3.3.3. Efecto de la infección en la regulación transcripcional de $B I R 1$............. 79

3.3.4. Efecto de SA sobre el patrón de metilación en el promotor de BIR1 ....... 83

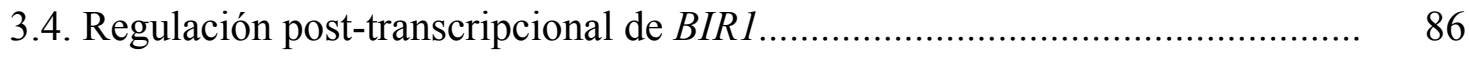

3.4.1. Análisis del patrón de degradación del RNA mensajero de BIRl durante la infección por TRV.

3.4.2. Análisis mutagénico de las secuencias de corte y de su efecto sobre la expresión de $B I R I$ en un sistema heterólogo

3.4.3. Caracterización del locus de MIR5658 en Arabidopsis........................... 90

3.4.4. Efecto del locus MIR5658 en la regulación post-transcripcional de BIRl. 93 
3.4.5. Efecto del silenciamiento génico en la regulación post-transcripcional de BIR1......

3.5. Relevancia biológica de la regulación de BIR1.

3.5.1. Análisis de la función estabilizadora de BIRl en un sistema heterólogo de expresión transitoria

3.5.2. Relevancia biológica de la regulación de $B I R 1$ : abordaje experimental...

100

3.5.2.1. Expresión de BIR1 mediada por el vector viral TRV-BIR1

3.5.2.1.1. Ensayo de infectividad de vectores virales TRV-BIR1 en $N$. benthamiana.

101

3.5.2.1.2. Efecto de las mutaciones en los puntos de corte sobre la expresión de $B I R l$ en plantas infectadas de $N$.

benthamiana.

3.5.2.1.3. Ensayo de infectividad de vectores virales TRV-BIR1 en Arabidopsis

3.5.2.2. Expresión inducible de $B I R l$ en plantas transgénicas de Arabidopsis.. 111

3.5.2.2.1. Construcción de plantas transgénicas para $B I R 1$ usando un sistema de expresión inducible

3.5.2.2.2. Caracterización de líneas sobreexpresoras de $B I R 1$ en Arabidopsis

3.5.2.2.3. Activación de la señalización inmune en plantas sobreexpresoras de $B I R 1$.

3.5.2.2.4. Estudio fenotípico de plantas transgénicas sobreexpresoras de BIR1.

3.5.2.2.5. Efecto de las dianas de degradación sobre la aparición de fenotipos morfológicos en plantas transgénicas sobreexpresoras de BIRl...

3.6. Estudio de otros factores de susceptibilidad en Arabidopsis

3.6.1. Efecto de la infección de TRV sobre la expresión de genes inducibles por la oscuridad (DIN) en Arabidopsis. 
4.1. Activación de la respuesta inmune dependiente de BIR1 durante las infecciones virales

4.2. BIR1, SA y resistencia antiviral frente a TRV.

4.3. SA y su función como activador de la expresión de $B I R l$ en infecciones virales.

4.4. El silenciamiento génico como elemento clave en la regulación de BIRl.

4.5. Silenciamiento génico y regulación de $B I R 1$ durante la infección viral.

4.6. Procesamiento endonucleolítico de transcritos de BIR1.....

4.7. Caracterización del locus MIR5658 y su efecto sobre la regulación posttranscripcional de BIR 1

4.8. Relevancia biológica de la regulación de $B I R 1$

4.9. Modelo de regulación de BIR1.

4.10. Inducción de genes $D I N$ y su efecto en la infección viral 


\section{ÍNDICE DE FIGURAS}

\section{Figuras}

Figura 1.1 Representación esquemática de la ruta de biogénesis de los miRNA. Página 8.

Figura 1.2 Representación esquemática de la ruta de biogénesis de casiRNAs. Página 9.

Figura 1.3 Representación esquemática de la ruta de biogénesis de tasiRNAs. Página 11.

Figura 1.4 Representación esquemática de la ruta de biogénesis de natsiRNAs. Página 12.

Figura 1.5 Representación esquemática de la ruta de biogénesis de vasiRNAs. Página 13.

Figura 1.6 Representación esquemática del proceso de silenciamiento transcripcional en Arabidopsis. Página 19.

Figura 1.7 Identificación a escala global de las dianas de silenciamiento por RNA. Página 32.

Figura 1.8 Perfil de degradoma de los genes procesados diferencialmente entre plantas control e infectadas. Página 33.

Figura 3.1 Acumulación de transcritos de BIRl en plantas infectadas. Página 65.

Figura 3.2 Acumulación de TRV y determinación de los niveles de proteína BIR1HA en mutantes birl-1 y líneas de complementación bir1-1/BIR1 HA. Página 66.

Figura 3.3 Acumulación de transcritos de PR1, PR4, PAD3 y WRKY7 en mutantes birl-1 infectados. Página 67.

Figura 3.4 Acumulación de transcritos de $B A K 1$ en plantas infectadas. Página 68.

Figura 3.5 Acumulación de TRV en mutantes bak1-5, sobir1-12 y birl sobirl-1. Página 68.

Figura 3.6 Acumulación de transcritos de $P R l$ y de TRV en plantas tratadas con SA. Página 69.

Figura 3.7 Acumulación de TRV en mutantes bir2-1. Página 69.

Figura 3.8 Acumulación de transcritos de BIRI en plantas tratadas con SA. Determinación de los niveles de transcrito GFP:GUS en plantas $\mathrm{P}_{\mathrm{BIR} 1}:$ GUS-GFP tratadas con SA. Página 68.

Figura 3.9 Acumulación de la hormona SA en Arabidopsis silvestres sanas, control e infectadas. Página 69. 
Figura 3.10 Acumulación de transcritos de BIRl y TRV en mutantes sid2-2 y nprl. Página 72.

Figura 3.11 Distribución de siRNAs derivados de BIRl en Arabidopsis silvestres inoculadas con extracto de planta sana. Página 73.

Figura 3.12 Acumulación de transcritos de BIRl y TRV en mutantes RdDM. Página 74.

Figura 3.13 Acumulación de transcritos de BIRl dependientes de PolV en Arabidopsis silvestres y el mutante nrpel. Página 74.

Figura 3.14 Diagrama esquemático de las técnicas de Chop-PCR y Chop-qPCR. Página 75.

Figura 3.15 Grado de metilación de las citosinas del promotor de BIRl determinado por Chop-PCR y Chop-qPCR en Arabidopsis silvestres y mutantes RdDM. Página 77.

Figura 3.16 Estado de metilación del promotor de BIRl empleando datos de WGBS. Página 78.

Figura 3.17 Ensayo de expresión de $G U S$ en transgénicas $\mathrm{P}_{\mathrm{BIR} 1}$ ::GFP:GUS infectadas y control. Determinación de los niveles de transcrito GFP:GUS. Página 79.

Figura 3.18 Distribución de siRNA derivados de $B I R 1$ en Arabidopsis silvestres infectadas. Página 80.

Figura 3.19 Grado de metilación de las citosinas del promotor de BIRl determinado por Chop-qPCR, en Arabidopsis silvestres infectadas. Página 81.

Figura 3.20 Acumulación de transcritos de BIRI en Arabidopsis silvestres y mutantes RdDM infectados. Página 81.

Figura 3.21 Estado de metilación del promotor de BIRl usando secuenciación por bisulfito específica de gen. Página 83.

Figura 3.22 Acumulación de transcritos de BIRl en hoja de roseta de Arabidopsis silvestres y mutantes RdDM Página 84 .

Figura 3.23 Grado de metilación de las citosinas del promotor de BIRl determinado por Chop-PCR y Chop-qPCR en Arabidopsis silvestres y mutantes RdDM tras un tratamiento con SA. Página 85.

Figura 3.24 Acumulación de transcritos de BIRl dependientes de PolV en Arabidopsis silvestres y el mutante nrpel tras un tratamiento con SA. Página 86.

Figura 3.25 Identificación de puntos de corte preferentes en el transcrito de BIRI mediante análisis PARE en Arabidopsis infectadas. Página 87.

Figura 3.26 Diagrama esquemático de la posición de los puntos de corte predichos en el transcrito de $B I R l$ denominados A, B, C y D. Página 87. 
Figura 3.27 Caracterización de las construcciones empleadas para la expresión de las formas silvestre (WT) y mutantes (m) del gen BIRl bajo el promotor 35S. Página 89.

Figure 3.28 Esquema del apareamiento del miR5658 con la región que contiene la diana A en el transcrito de BIR1. Página 91.

Figura 3.29 Representación esquemática del par antisentido formado por el locus At4g39838 que contiene el miR5658 y el locus At4g39840. Página 92.

Figura 3.30 Distribución de las lecturas de sRNAs secuenciadas en Arabidopsis infectadas. Página 92.

Figura 3.31 Caracterización de líneas de inserción T-DNA del locus At4g39838. Página 93.

Figura 3.32 Acumulación de transcritos de BIRl y TRV en Arabidopsis silvestres y líneas de inserción T-DNA del locus At4g39838. Página 94.

Figura 3.33 Representación esquemática de las construcciones con las secuencias precursoras del miR5658 en el locus At4g39838. Página 95.

Figura 3.34 Determinación de los niveles de proteína BIR1-HA y GFP-HA en presencia de precursores de miR5658 y de miRNA heterólogos (miR399, miR158, miR171). Página 95.

Figura 3.35 Comparación de la acumulación de siRNAs derivados de BIRl determinada por ultrasecuenciación entre plantas infectadas y control. Página 96.

Figura 3.36 Acumulación de transcritos de BIRl en mutantes del silenciamiento infectadas. Página 98.

Figura 3.37 Análisis de expresión de la proteína GFP en hojas de N. benthamiana infiltradas con BIR1, con HC-Pro o con vector vacío. Página 100.

Figura 3.38 Diagrama representativo del clon infeccioso de TRV empleado para la expresión de BIR1-HA y sus variantes de secuencia. Página 101.

Figura 3.39 Esquema representativo de la construcción que expresa BIRl conjugado con el reportero mCherry bajo un promotor inducible por DEX. Página 101.

Figura 3.40 Caracterización de la expresión en $N$. Benthamiana de las construcciones TRV BIR1. Página 102.

Figura 3.41 Diagrama esquemático de las construcciones derivadas de TRV2 empleadas para la expresión de las distintas versiones de secuencia de BIR1. Página 103.

Figura 3.42 Determinación de los niveles de acumulación de la proteína GFP-HA y BIR1-HA en N. Benthamiana coexpresados junto a TRV. Página 104. 
Figura 3.43 Determinación de los niveles de acumulación de la proteína BIR1 silvestre (WT) y mutante (mA1, mA2, mA3 y mBmCmD). Página 105.

Figura 3.44 Determinación de los niveles de acumulación de la proteína GFP-HA en muestras de hojas de $N$. benthamiana agroinfiltradas con TRV1 y el TRV2-5'UTR-HAGFP en su versión silvestre o mutada (TRV25'UTRmA-HAGFP). Página 106.

Figura 3.45 Fenotipos morfológicos en plantas de Arabidopsis inoculadas con los vectores recombinantes TRV-GFP ó TRV-BIR1 WT. Página 107.

Figura 3.46 Acumulación de los transcritos de BIRl, PRl, PR4 y TRV en plantas de Arabidopsis infectadas con los vectores recombinantes TRV-GFP o TRV-BIR1 WT. Página 109.

Figura 3.47 Fenotipos morfológicos y acumulación de transcritos de BIRI en plantas de Arabidopsis inoculadas con los vectores recombinantes TRV-GFP, TRV-BIR1 mA y TRV-BIR1 mBmCmD. Página 110.

Figura 3.48 Expresión de proteína de fusión BIR1-mCherry bajo el promotor inducible con DEX en células epidérmicas de $N$. benthamiana. Página 112.

Figura 3.49 Caracterización y estudio de crecimiento en plantas transgénicas BIR1 WT cultivadas en presencia y ausencia de DEX. Página 114.

Figura 3.50 Acumulación de transcritos de PR1, PR4, WRKY29 y PAD3 en líneas transgénicas BIR1 WT. Página 115.

Figura 3.51 Expresión de proteína de fusión BIR1-mCherry bajo el promotor inducible con DEX en células epidérmicas de cotiledón de Arabidopsis para las líneas transgénicas BIR1 (WT, mA, mBmCmD). Página 116.

Figura 3.52 Determinación de los niveles de proteínas MAP kinasas fosforiladas y acumulación de transcritos de FRK1 en las líneas transgénicas BIR1 WT. Página 117.

Figura 3.53 Fenotipos morfológicos en plantas silvestres de Arabidopsis (Col-0) y en las líneas transgénicas BIR1 WT. Página 119.

Figura 3.54 Determinación de los niveles de proteína BIR1-mCherry y acumulación de transcritos de PR1, PR4, PAD3 y WRKY29 en Arabidopsis silvestres y líneas transgénicas BIR1 WT cultivadas en tierra y tratadas con y sin DEX. Página 121.

Figura 3.55 Distribución porcentual de fenotipos en plantas de genotipo silvestre (Col-0) y transgénicas BIR1 $\mathrm{mBmCmD}$ tras el tratamiento con DEX. Página 123.

Figura 3.56 Acumulación de transcritos de los genes DIN1, DIN6 y DIN11 Arabidopsis infectadas. Página 124. 
Figura 3.57 Acumulación de transcritos de DIN1, DIN6, DIN11 y TRV en mutantes din1, din6 y en líneas RNAi-DIN11. Acumulación viral en protoplastos de líneas RNAi-DIN11. Página 126.

Figura 4.1 Acumulación de la hormona JA en hojas de roseta de Arabidopsis silvestres sanas, control e inoculadas con TRV. Página 131.

Figura 4.2 Identificación de siRNAs con que potencial para interaccionar con BIRI en Arabidopsis. Página 136.

Figura 4.3 Modelo de regulación de BIRl. Página 139. 



\section{ÍNDICE DE TABLAS}

\section{Tablas}

Tabla 1.1 Potenciales dianas de silenciamiento mediado por RNA detectadas en Arabidopsis infectadas con TRV. Página 32.

Tabla 2.1 Cebadores empleados en ensayos de qRT-PCR. Página 61.

Tabla 2.2 Cebadores empleados en experimentos de regulación transcripcional. Página 62.

Tabla 3.1. Descripción de los seis fenotipos morfológicos observados en plantas de Arabidopsis infectadas con TRV-BIR1 WT. Página 107.

Tabla 3.2. Cambios en la expresión de genes inducibles por oscuridad DIN en hojas, inflorescencias y raíces de Arabidopsis infectadas con TRV respecto a los controles sin infectar. Página 124. 



\section{ABREVIATURAS}

A

AGO

ANOVA

AP2

Avr

BAK1

BIK1

BIR1

BrEt

$\mathrm{C}$

CaMV

casiRNA

$\mathrm{CC}$

cDNA

$\mathrm{Cl}_{2} \mathrm{Mg}$

$\mathrm{ClK}$

CILi

$\mathrm{ClNa}$

CMT3

CMV

CNL

Col-0

cpm

DAMP

DCL

DCP

DEX

DIN

DO

dpa

dpi

dpt

DRB4

DRM2

Adenina

ARGONAUTA

Análisis de varianza

APETALA 2

Proteínas de Avirulencia (Avirulence)

BRI1-ASSOCIATED RECEPTOR KINASE 1

BOTRYTIS-INDUCED KINASE 1

BAK1-INTERACTING RECEPTOR-LIKE KINASE 1

Bromuro de etidio

Citosina

Virus del mosaico de la coliflor (Cauliflower mosaic virus)

Pequeños RNA de interferencia que actúan en cis (Cis-acting small interfering RNA)

Dominio de Hélice superenrrollada (Coiled-Coil)

ADN complementario

Cloruro de magnesio

Cloruro potásico

Cloruro de litio

Cloruro de sodio

CHROMOMETHYLASE 3

Virus del mosaico del pepino (Cucumber mosaic virus)

Genes CC-NB-LRRs

Columbia-0

Cuentas por minuto

Patrones Moleculares Asociados al Daño (Damage-Associated Molecular Pattern)

DICER-LIKE

Decapping

Dexametasona

DARK INDUCIBLE GENES

Densidad óptica

Días post agroinfiltración

Días post inoculación

Días post tratamiento

DOUBLE-STRANDED RNA BINDING PROTEIN

DOMAINS REARRANGED METHYLTRANSFERASE 2 


\begin{tabular}{|c|c|}
\hline dsDNA & DNA bicatenario (double-strand DNA) \\
\hline dsRBD & Dominio de unión al dsRNA (dsRNA Binding Domain) \\
\hline dsRNA & RNA bicatenario (double-strand RNA) \\
\hline ea-siRNAs & siRNAs epigenéticamente activados (epigenetically-activated siRNAs) \\
\hline EDS1 & ENHANCED DISEASE SUSCEPTIBILITY 1 \\
\hline EDTA & Ácido etilen-diamino-tetracético \\
\hline ET & Etileno \\
\hline ETI & Inmunidad desencadenada por efectores (Effector Triggered Immunity) \\
\hline $\mathrm{EtOH}$ & Etanol \\
\hline Fg122 & Flagelina \\
\hline FLS2 & FLAGELLIN SENSITIVE 2 \\
\hline FT & Factores de transcripción \\
\hline G & Guanina \\
\hline \multirow[t]{2}{*}{ GC-TOF-MS } & Espectrometría de masas acoplada a cromatografía de gases (Gas \\
\hline & Chromatography-Time-of-Flight Mass Spectrometry) \\
\hline GDH & Glutamate dehydrogenase \\
\hline GFP & Proteína verde fluorescente (Green Fluorescent Protein) \\
\hline GUS & $\beta$-glucuronidasa \\
\hline $\mathrm{HCl}$ & Ácido clorhídrico \\
\hline HR & Respuesta hipersensible (Hypersensitive Response) \\
\hline ICS1 & ISOCHORISMATE SYNTHASE 1 \\
\hline IGN22 & Región intergénica 22 (Intergenic Region 22) \\
\hline JA & Ácido Jasmónico (Jasmonic Acid) \\
\hline $\mathrm{Kb}$ & Kilobases \\
\hline $\mathrm{kDa}$ & Kilodalton \\
\hline LB & Medio Luria-Bertani \\
\hline LMW-RNA & RNA de bajo peso molecular (Low Molecular Weight RNA) \\
\hline LRR & Repeticiones ricas en leucinas (Leucine Rich Repeat) \\
\hline \multirow[t]{2}{*}{ MAMP } & Patrones Moleculares Asociados al Microbio (Microbe Associated \\
\hline & Molecular Pattern) \\
\hline MAPK & Quinasas activadas por mitógeno (Mitogen Activated Protein Kinase) \\
\hline MCS & Sitio de clonación múltiple (Multiple Cloning Site) \\
\hline MeJA & Metil Jasmonato \\
\hline MES & Ácido 2-N-morfolino-etanosulfónico \\
\hline MET1 & DNA METHYLTRANSFERASE 1 \\
\hline miRNA & microRNA \\
\hline MOPS & 3-morfolino-propano-sulfónico \\
\hline MS & Murashige y Skoog \\
\hline
\end{tabular}




\begin{tabular}{|c|c|}
\hline NAT & $\begin{array}{l}\text { Transcrito potencial con configuración antisentido (Natural Antisense } \\
\text { Transcript) }\end{array}$ \\
\hline natsiRNA & $\begin{array}{l}\text { Pequeño RNA de interferencia derivado de transcrito potencial con } \\
\text { configuración antisentido (Natural antisense transcripts small interfering } \\
\text { RNA) }\end{array}$ \\
\hline NB & Dominio de unión a nucleótidos (Nucleotide Binding) \\
\hline $\mathrm{Nm}$ & Nanómetro \\
\hline NRPD1 & NUCLEAR RNA POLYMERASE D1 \\
\hline NRPE1 & NUCLEAR RNA POLYMERASE D1B \\
\hline $\mathrm{Nt} / \mathrm{nts}$ & Nucleótido/s \\
\hline OXNPR1 & Líneas complementadas de NPR1 \\
\hline PAD4 & PHYTOALEXIN DEFICIENT 4 \\
\hline PAMP & Patrones Moleculares Asociados al Patógeno (Pathogen Associated \\
\hline & Molecular Pattern) \\
\hline $\mathrm{Pb}$ & Pares de bases \\
\hline PCR & Reacción en cadena de la polimerasa (Polymerase Chain Reaction) \\
\hline PEBV & Virus de bronceado temprano del guisante (Pea early browning virus) \\
\hline Pol & RNA Polimerasa dependiente de DNA \\
\hline Pol II & RNA Polimesasa II \\
\hline Pol IV & RNA Polimerasa IV \\
\hline pre-miRNA & Precursor micro RNA \\
\hline pri-miRNA & Transcrito primario de micro RNA \\
\hline PRR & Receptores de reconocimiento de patrones (Pattern Recognition Receptor) \\
\hline PTGS & Silenciamiento génico post-transcripcional (Post-Transcriptional Gene \\
\hline & Silencing) \\
\hline PTI & Inmunidad desencadenada por PAMP (PAMP Triggered Immunity) \\
\hline $\mathrm{R}$ & Genes o proteínas de resistencia \\
\hline $\mathrm{RdDM}$ & Metilación de DNA mediada por RNA (RNA-directed DNA methylation) \\
\hline RDR & RNA POLIMERASA DEPENDIENTE DE RNA \\
\hline RIP-seq & Inmuniprecipitación de RNA seguida de secuenciación \\
\hline RISC & Complejo inductor de silenciamiento (RNA Induced Silencing Complex) \\
\hline RIST & Inductor de silenciamiento transcripcional (RNA Induced Transcriptional \\
\hline & Silencing) \\
\hline RLK & Quinasa receptora (Receptor Like Kinase) \\
\hline RLP & Proteína receptora sin actividad quinasa (Receptor Like Protein) \\
\hline ROS & Especies reactivas del oxígeno (Reactive Oxygen Species) \\
\hline $\mathrm{rpm}$ & Revoluciones por minuto \\
\hline P5 & RECOGNITION OF PERONOSPORA PARASITICA 5 \\
\hline
\end{tabular}




\begin{tabular}{|c|c|}
\hline rRNA & RNA ribosómico \\
\hline $\mathrm{RT}$ & Transcripción inversa (Retro-Transcriptase) \\
\hline SA & Ácido salicílico (Salycilic Acid) \\
\hline SAR & Resistencia sistémica adquirida (Systemic Acquired Resistance) \\
\hline SD & Desviación estándar (Standard Deviation) \\
\hline SDS & dodecil sulfato sódico \\
\hline sidRNAs & siRNAs independientes de DCL (siRNAs independent of DCLs) \\
\hline siRNA & Pequeño RNA de interferencia (small interfering RNAs) \\
\hline SNC1 & SUPPRESSOR OF NPR1-1 CONSTITUTIVE 1 \\
\hline SOBIR1 & SUPPRESSOR OF BIR1 1 \\
\hline sRNA & Pequeño RNA (small RNA) \\
\hline ssDNA & DNA de cadena sencilla (single strand DNA) \\
\hline ssRNA & RNA de cadena sencilla (single strand RNA) \\
\hline TAIR & $\begin{array}{l}\text { La fuente de información de Arabidopsis (The Arabidopsis Information } \\
\text { Resource) }\end{array}$ \\
\hline tasiRNA & $\begin{array}{l}\text { Pequeños RNAs de interferencia que actúan en trans (Trans-acting small } \\
\text { interfering RNA) }\end{array}$ \\
\hline TCV & Virus del arrugado del nabo (Turnip crinkle virus) \\
\hline TEV & Virus del grabado del tabaco (Tobacco etch virus) \\
\hline TGS & Silenciamiento génico transcripcional (Transcriptional Gene Silencing) \\
\hline TIR & Receptores Toll e Interleukina-1 (Toll and Interleukin-1 receptors) \\
\hline TRV & Virus del cascabeleo del tabaco (Tobacco rattle virus) \\
\hline TuMV & Virus del mosaico del nabo (Turnip mosaic virus) \\
\hline TYLCV & $\begin{array}{l}\text { Virus del enrollado amarillo de la hoja del tomate (Tomato yellow leaf curl } \\
\text { virus) }\end{array}$ \\
\hline UTR & Región no traducible \\
\hline UV & Luz ultravioleta \\
\hline $\mathrm{V}$ & Voltio \\
\hline vasiRNA & siRNA asociados a virus (viral-associated siRNAs) \\
\hline VIGS & Silenciamiento génico inducido por virus (virus-induced gene silencing) \\
\hline VSR & $\begin{array}{l}\text { Proteínas virales supresoras del silenciamiento génico (Viral Supperssor of } \\
\text { RNA silencing) }\end{array}$ \\
\hline vsRNA & Pequeño RNA derivado de virus (virus-derived small RNA) \\
\hline WT & Silvestre \\
\hline X-gluc & 5-bromo-4-chloro-3-indolyl- $\beta$-D-glucuronide \\
\hline XRN & Exoribonucleasa \\
\hline
\end{tabular}




\section{RESUMEN}

Los patógenos de plantas representan un problema global para la producción de alimentos, la economía y la biodiversidad. Para defenderse de esta amenaza las plantas han desarrollado una compleja red inmune con respuestas que van desde barreras físicas preformadas a todo un sistema de defensas inducibles. La movilización de esta respuesta inmune comienza cuando la célula vegetal detecta ciertas estructuras del patógeno e inicia una cascada de señalización que activa las defensas de la planta. Este mecanismo ha demostrado ser efectivo frente a infecciones microbianas, de hongos y oomicetos, sin embargo, su contribución en la respuesta defensiva frente a infecciones virales no se ha estudiado suficientemente. La adecuada regulación de esta inmunidad es imprescindible para garantizar su eficacia y evitar respuestas inadecuadas. Así el inicio de la ruta de señalización que activa las defensas está controlado por proteínas maestras reguladoras de la membrana plasmática. Entre ellas, BIR1 se ha descrito como un represor de la respuesta inmune y la muerte celular que actúa bloqueando la función de los reguladores positivos necesarios para la activación de la señal inmune. En este trabajo hemos utilizado la planta modelo Arabidopsis thaliana para estudiar el papel que desempeña BIR1 y otros componentes de la ruta de señalización asociados a BIR1 en la infección viral. Nuestros resultados demuestran que los virus de plantas inician una respuesta inmune basal que activa transcripcionalmente BIR1 a través de la hormona vegetal ácido salicílico (SA). La pérdida de función de BIR1 se asocia con un fenotipo de resistencia antiviral que es independiente de la defensa mediada por SA y de la muerte celular, lo que sugiere que BIR1 actúa como regulador negativo de la resistencia antiviral. Hemos demostrado que la sobreexpresión de BIR1 se asocia con la aparición de fenotipos autoinmunes que coinciden con un incremento en la expresión de genes de defensa y con muerte celular. Este fenotipo es similar al observado en plantas deficientes en BIR1. Por ello, nuestros resultados sugieren que BIR1 necesita regularse estrictamente dentro de unos límites funcionales óptimos de expresión que garanticen un control adecuado de la respuesta inmune. En esta tesis hemos demostrado que el silenciamiento génico es fundamental para mantener la homeostasis de BIR1. El silenciamiento transcripcional regula la expresión de BIR1 de forma constitutiva a través de la metilación de su promotor. Mientras, el silenciamiento génico actúa sobre BIR1 post-transcripcionalmente a través de un procesamiento específico de secuencia de sus RNAs mensajeros que opera preferentemente cuando los niveles de acumulación de BIR1 superan los umbrales deseables, por ejemplo tras la inducción transcripcional que sufre BIR1 tras la infección viral. La infección viral en las plantas implica una considerable reprogramación de la expresión génica. En esta tesis hemos estudiado el efecto de varios genes asociados a la senescencia, conocidos como genes DIN, durante las infecciones virales. Nuestros datos sugieren que DIN11 desempeña un papel 
esencial como factor de susceptibilidad controlando la proliferación viral en las etapas tempranas de la infección. En conjunto esta tesis ha caracterizado la función durante la infección de dos genes que se activan en respuesta al virus: BIR1 y DIN11 y ha desvelado un doble mecanismo de regulación en el control de la homeostasis del gen de defensa BIR1 que puede ser común a otros componentes de la inmunidad. 


\section{ABSTRACT}

Plant pathogens represent a global threat for food production, economy and biodiversity. To defend themselves, plants have developed a complex defense network that goes from preformed physical barriers to inducible defense strategies. The innate immune response begins when plant cells detect pathogen-associated molecular patterns to initiate a signaling cascade that activates a multi-layered plant defense. This mechanism is widely effective against microbes such as bacteria, fungi or oomycetes. However, its contribution to antiviral defense remains elusive. Plant immune has to be tightly regulated to avoid undesirable effects associated to the constitutive activation of plant defenses. As a result, master regulators located at the plasma membrane are essential to control the immune signaling pathway. Among them, BIR1 negatively regulates the immune response and cell death by blocking positive regulators that initiate the immune signal cascade. In this work, we have employed the model plant Arabidopsis thaliana to study the role of BIR1 and other components of the BIR1associated signaling pathway during viral infections. Our results demonstrate that plant viruses trigger a basal immune response in which BIR1 is transcriptionally activated through the plant hormone salicylic acid (SA). Loss-of-function of BIR1 leads to antiviral resistance, which is independent of the SA-mediated defense responses and cell death, suggesting that BIR1 acts as a negative regulator of antiviral defenses. We demonstrate that overexpression of BIR1 causes autoimmune phenotypes, which correlates with an increase in the expression of defense-related genes and cell death. This phenotype, which also includes a range of morphological abnormalities, is similar to that observed in BIR1-deficient plants. Thus, our results suggest that BIR1 needs to be tightly controlled within optimal functional expression threshold that guarantees a proper control of the immune response. In this thesis, we demonstrate that gene silencing is essential to maintain BIR1 homeostasis. Transcriptional silencing regulates BIR1 expression in a constitutive manner by controlling methylation levels in its promoter, whereas post-transcriptional gene silencing regulates BIR1 by mRNAs sequence-specific cleavage. Post-transcriptional regulation seems to be conditional and gains relevance when BIR1 accumulation exceeds the optimal threshold, for instance, upon viral infection. Plant viral infection implies profound changes in gene expression. In this thesis, we study the effect of several senescence-associated genes, known as DIN genes, during viral infections. Our data suggest that DIN11 performs an essential role as a susceptibility factor controlling viral proliferation in the early stages of infection. Summarizing, this thesis studies the contribution to viral infection of two virusresponsive genes (BIR1 and DIN11) and reveals a double regulation mechanism of BIR1 that could be common to other immunity components. 

1. INTRODUCCIÓN 



\section{INTRODUCCIÓN}

Los virus de plantas son parásitos obligados que utilizan factores y recursos celulares para replicarse y moverse en el huésped infectado (Heinlein, 2015). En este proceso, las plantas responden a la infección mediante diversos mecanismos defensivos que los virus deben ser capaces de evadir o suprimir (Garcia-Ruiz, 2018). Estos mecanismos incluyen la inmunidad innata, la autofagia de proteínas virales y el silenciamiento de genes. Por lo tanto, el desenlace de la infección está determinado genéticamente por la disponibilidad de factores del huésped necesarios para la replicación y el movimiento del virus (factores provirales) y por el equilibrio entre la defensa de la planta (factores antivirales) y la supresión viral de las respuestas de defensa (Garcia-Ruiz, 2018). Los factores provirales o de susceptibilidad determinan por tanto las relaciones de compatibilidad planta-virus ya que permiten el establecimiento de la infección al participar en procesos esenciales para el virus. Estos procesos afectan a la traducción de RNA viral, formación del complejo de replicación, acumulación o actividad de proteínas de replicación del virus, movimiento local y sistémico del virus, ensamblaje del virión y transmisión (Garcia and Pallas, 2015). Por el contrario, las interacciones incompatibles se caracterizan por la ausencia de factores celulares provirales esenciales para que el virus se replique o se mueva, por la presencia de un mecanismo de defensa que bloquee la infección en cualquiera de sus etapas, o por una combinación de ambos (Soosaar et al., 2005). En este escenario incompatible, la capacidad infectiva del virus se reduce y el resultado final es un fenotipo resistente caracterizado bien por una reducción drástica en la acumulación de virus y/o síntomas leves con respecto a las plantas susceptibles, o bien por la ausencia total de infección.

\subsection{Inmunidad basal en plantas}

Si bien la observación superficial podría insinuar que el mundo vegetal posee un nivel de complejidad relativamente bajo, las plantas son organismos sensibles capaces de resolver problemas complejos mediante estrategias mucho más refinadas de las que se observan a primera vista. Un ejemplo de esta sofisticación es la red de estrategias defensivas que han desarrollado para protegerse de los agentes fitopatógenos, los cuales representan un problema global que afecta a la biodiversidad, a la producción y a la seguridad alimentaria. Barreras físicas preformadas como la pared celular, la cera de la cutícula, la presencia de pelos o la corteza desempeñan una importante función protectora a la vez que proporcionan rigidez y soporte a la planta. Además, las plantas han desarrollado a lo largo de la evolución una batería de defensas inducibles que 
conforman su sistema inmune y con las que las células vegetales pueden detectar y responder a un patógeno invasor (Dangl and Jones, 2001).

\subsubsection{La inmunidad basal en plantas: Mecanismos generales de acción}

La movilización de la respuesta inmune comienza cuando la célula vegetal detecta ciertas estructuras y/o compuestos microbianos, generalmente conservados, y que se conocen como patrones moleculares asociados al patógeno/microbio (PAMPs/MAMPs, del inglés pathogen/microbial-associated molecular patterns) (Boller and Felix, 2009; Zipfel, 2009). De forma similar las células pueden reconocer restos extracelulares generados por enzimas líticas del patógeno e inducir una respuesta inmune. Son los denominados patrones moleculares asociados al daño (DAMPs, del inglés damageassociated molecular pattern). El reconocimiento de estos ligandos se lleva a cabo a través de complejos proteicos de la membrana celular conocidos como receptores de reconocimiento de patrones (PRR, del inglés pathogen recognition receptors) (Boller and Felix, 2009). La unión de los PAMPs/MAMPs/DAMPs al receptor PRR dispara una cascada de señalización controlada por quinasas activadas por calcio y quinasas activadas por mitógeno (factor que promueve la proliferación celular en eucariotas) (MAPK, del inglés mitogen-activated protein kinases) (Tena et al., 2011; Macho and Zipfel, 2014).

Esta red de señalización controla la actividad de respuestas defensivas tales como la síntesis de proteínas y compuestos de defensa, la aclimatación metabólica, la alcalinización del citoplasma (que favorece el control de la acumulación de especies reactivas del oxígeno), la producción de hormonas de defensa, el cierre de estomas, etc. (Boller and Felix, 2009). Sobre esta serie de acontecimientos se organiza la inmunidad basal de las plantas, también conocida como inmunidad desencadenada por PAMP (PTI, del inglés PAMP-triggered immunity) (Jones and Dangl, 2006).

Dado que el potencial infeccioso de un patógeno depende en gran medida de su capacidad para evadir o contrarrestar las barreras defensivas de la planta, éstos han evolucionado desarrollando una serie de proteínas efectoras que contribuyen a su virulencia. Estos efectores interfieren con distintas etapas de la inmunidad basal y activan la transcripción de genes de la planta obstaculizando la actividad de factores de transcripción del huésped o alterando la estructura de la cromatina (Asai and Shirasu, 2015). Como respuesta, las plantas producen un repertorio adicional de receptores inmunológicos codificados por genes de resistencia (gen R) que reconocen al efector patogénico y disparan una segunda línea de inmunidad innata conocida como inmunidad desencadenada por efectores (ETI, del inglés effector-triggered immunity) (Gururani et al., 2012). 
El grupo más amplio de proteínas $\mathrm{R}$ lo forman receptores intracelulares con dominios de unión a nucleótidos (NB, del inglés nucleotide-binding) y repeticiones ricas en leucinas (LRR, del inglés leucine-rich repeat) (Hammond-Kosack and Jones, 1997; Gururani et al., 2012; Macho and Zipfel, 2014). Algunos genes R codifican proteínas NB-LRR con un dominio en posición amino terminal similar a los receptores "Toll and Interleukin-1" (TIR1, del inglés Toll and Interleukin-1 receptors) que median respuestas inmunes en animales (TIR-NB-LRR). Otros codifican proteínas con un dominio de hélice superenrollada (CC, del inglés coiled-coil) en su extremo amino (CCNB-LRR) (Meyers et al., 2003; Li et al., 2015). Cuando las proteínas R reconocen al efector patogénico, directa o indirectamente a través de una proteína intermediaria, se dispara una batería de respuestas inmunes que en ocasiones se superponen con mecanismos asociados a la inmunidad basal y que generalmente llevan a una muerte celular programada conocida como respuesta hipersensible (HR, del inglés hypersensitive response) (Coll et al., 2011).

\subsubsection{Vías de señalización en la respuesta inmune}

La percepción específica de las estructuras PAMP microbianas induce la heterodimerización de los receptores de membrana PRR (Tena et al., 2011), los cuales incluyen quinasas receptoras (RLK, del inglés receptor-like kinase) y proteínas receptoras sin actividad quinasa (RLP, del inglés receptor-like protein) (Zipfel, 2009). Las proteínas de membrana RLK están compuestas de un dominio extracelular con el que unen el ligando microbiano, un dominio transmembrana y un dominio intracelular cuya actividad quinasa les permite fosforilar otras proteínas operando así como transductor de señales (Park et al., 2012). Esta unión receptor-ligando induce la asociación del receptor con las proteínas RLK de membrana BRI1-ASSOCIATED RECEPTOR KINASE 1 (BAK1) y BOTRYTIS-INDUCED KINASE 1 (BIK1) seguida de una transfosforilación de sus dominios quinasa (Korner et al., 2013). Este proceso implica un cambio conformacional que dispara una cascada de señalización mediada por MAPKs (Chinchilla et al., 2007; Park et al., 2012). Esta vía permite regular la actividad y síntesis de factores de transcripción que controlan la expresión de genes de defensa (Jones and Dangl, 2006), por lo que BAK1 actúa como regulador esencial en la inmunidad basal de las plantas. BAK1 es capaz de interaccionar con distintos receptores RLK y RLP e integrar la percepción de múltiples patrones microbianos en eventos de señalización de defensa (Chinchilla et al., 2009). Es además un componente crítico en la respuesta ETI ya que ejerce como regulador negativo de la muerte celular programada en respuesta a patógenos necrotrofos (Kemmerling et al., 2007). 


\subsection{Silenciamiento génico}

\subsubsection{Mecanismos generales de acción e importancia biológica}

El silenciamiento génico, también conocido como silenciamiento por RNA, es un mecanismo clave en la regulación génica de las plantas y cuyos componentes están conservados en eucariotas (Ruiz-Ferrer and Voinnet, 2009). Desempeña un papel esencial en el mantenimiento de la integridad del genoma y en el control de procesos de crecimiento y desarrollo, estabilidad genómica y respuesta a estrés biótico y abiótico (Chapman and Carrington, 2007). El silenciamiento génico opera a través de dos grandes mecanismos que implican tanto la regulación transcripcional de los genes a través de procedimientos de metilación del DNA genómico (Zilberman et al., 2003; Zheng et al., 2007; Matzke et al., 2015) como su control post-transcripcional promoviendo la degradación de los RNAs mensajeros o bloqueando su traducción (Llave et al., 2002; Brodersen et al., 2008; Eamens et al., 2008).

\subsubsection{Bases moleculares del silenciamiento génico}

El silenciamiento génico es un mecanismo que se induce en presencia de RNA bicatenario (dsRNA, del inglés double-strand RNA) y que emplea pequeñas moléculas de RNA de 20 a 24 nucleótidos (sRNAs, del inglés small RNAs) para conferir especificidad a la regulación. Los sRNAs guían los complejos proteicos efectores de silenciamiento hacia sus secuencias diana complementarias (Brodersen and Voinnet, 2006). Estos complejos se denominan RIST (del inglés RNA induced transcriptional silencing) o RISC (del inglés RNA induced silencing complex) según regulen el DNA a nivel transcripcional o el RNA a nivel post-transcripcional, respectivamente (Guo et al., 2016).

\subsubsection{Caracterización de los sRNAs endógenos}

Los sRNAs se han clasificado en dos grandes grupos conocidos como microRNAs (miRNAs) y pequeños RNAs interferentes (siRNAs, del inglés small interfering RNAs) de los que a su vez se han identificado al menos tres subclases principales: siRNAs que actúan en trans (tasiRNAs, del ingés trans-acting siRNAs), siRNAs derivados de transcritos naturales antisentido (natsiRNAs, del inglés natural antisense transcript siRNAs) y siRNAs que actúan en cis (casiRNAs, del inglés cis-acting siRNAs) (Borges and Martienssen, 2015). 


\subsubsection{1. miRNAs}

Los miRNAs y los siRNAs presentan la misma estructura y modo de acción pero tienen diferentes orígenes. En plantas, los miRNAs son producto de la acción de la RNA polimerasa II (Pol II) que transcribe los genes nucleares MIR a transcritos primarios (pri-miRNAs). Estos pri-miRNAs son transcritos largos (aproximadamente 1 $\mathrm{Kb})$ que no codifican ninguna proteína, pero tienen el potencial de adoptar estructuras muy plegadas por autocomplementariedad de secuencia (Park et al., 2005; Xie et al., 2005). La proteína Dicer-like 1 (DCL1) (Ver apartado 2.4.1) cataliza el procesamiento inicial de estos transcritos primarios liberando una región conocida como precursor de miRNA (pre-miRNA). Suele tener entre 70 y 100 nts de longitud y estructura secundaria estable en forma de horquilla (Park et al., 2005; Xie et al., 2005). Este dúplex de RNA constituye el sustrato de dsRNA sobre el que actúa DCL1 para generar dúplex maduros del miRNA (Figura 1.1). Ocasionalmente, y de forma independiente a DCL1, DCL3 u otras DCL pueden procesar algunos pre-miRNAs y producir miRNAs no canónicos de 22 a 25 nts (Wu et al., 2010; Yamasaki and Cerutti, 2017). El miRNA maduro se incorpora selectivamente a los complejos efectores del silenciamiento mediante su unión a proteínas de la familia génica Argonaute (AGO) (Ver apartado 2.5) (Baumberger and Baulcombe, 2005). 


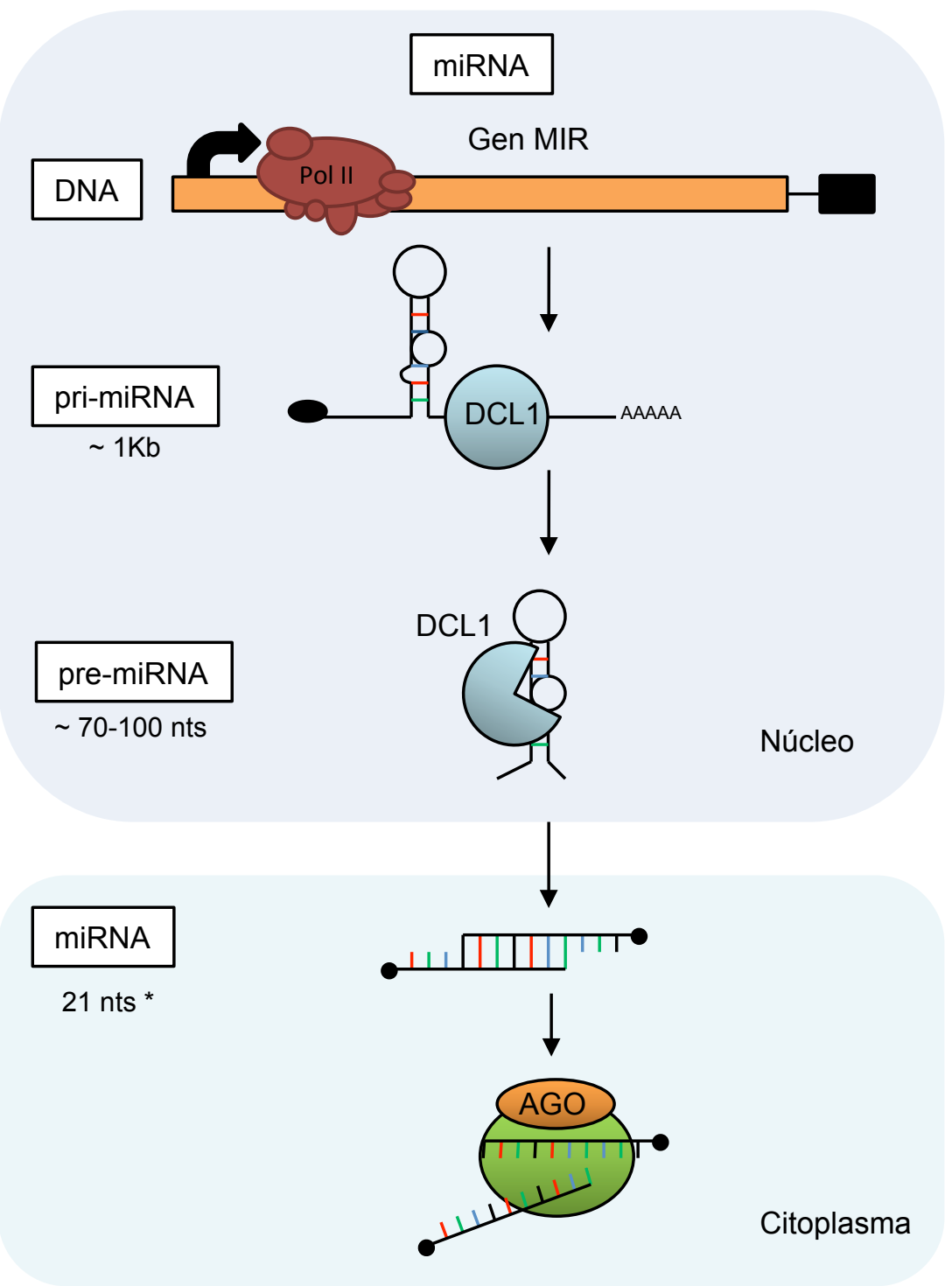

Figura 1.1. Representación esquemática de la ruta de biogénesis de los miRNA en Arabidopsis.

\subsubsection{SiRNAs}

Los siRNAs se originan a partir de RNAs bicatenarios, relativamente largos, resultantes del apareamiento de cadenas complementarias y antiparalelas. Estos RNAs de cadena doble son el sustrato de varias enzimas DCL que de forma jerárquica los digieren para generar poblaciones de siRNAs (Borges and Martienssen, 2015).

Los casiRNAs engloban la mayoría de los siRNAs endógenos de la célula vegetal y proceden mayoritariamente de la heterocromatina, donde se asocian con secuencias repetidas del DNA y elementos transponibles (Kasschau et al., 2007; Moazed, 2009). No obstante, son también frecuentes en regiones intergénicas, promotores o secuencias codificadoras de proteínas. Estos siRNAs tienen un tamaño mayoritario de $24 \mathrm{nts}$ y participan fundamentalmente en procesos de metilación del DNA dependiente de RNA (ver apartado 3.2) (Xie and Yu, 2015) (Figura 1.2). 


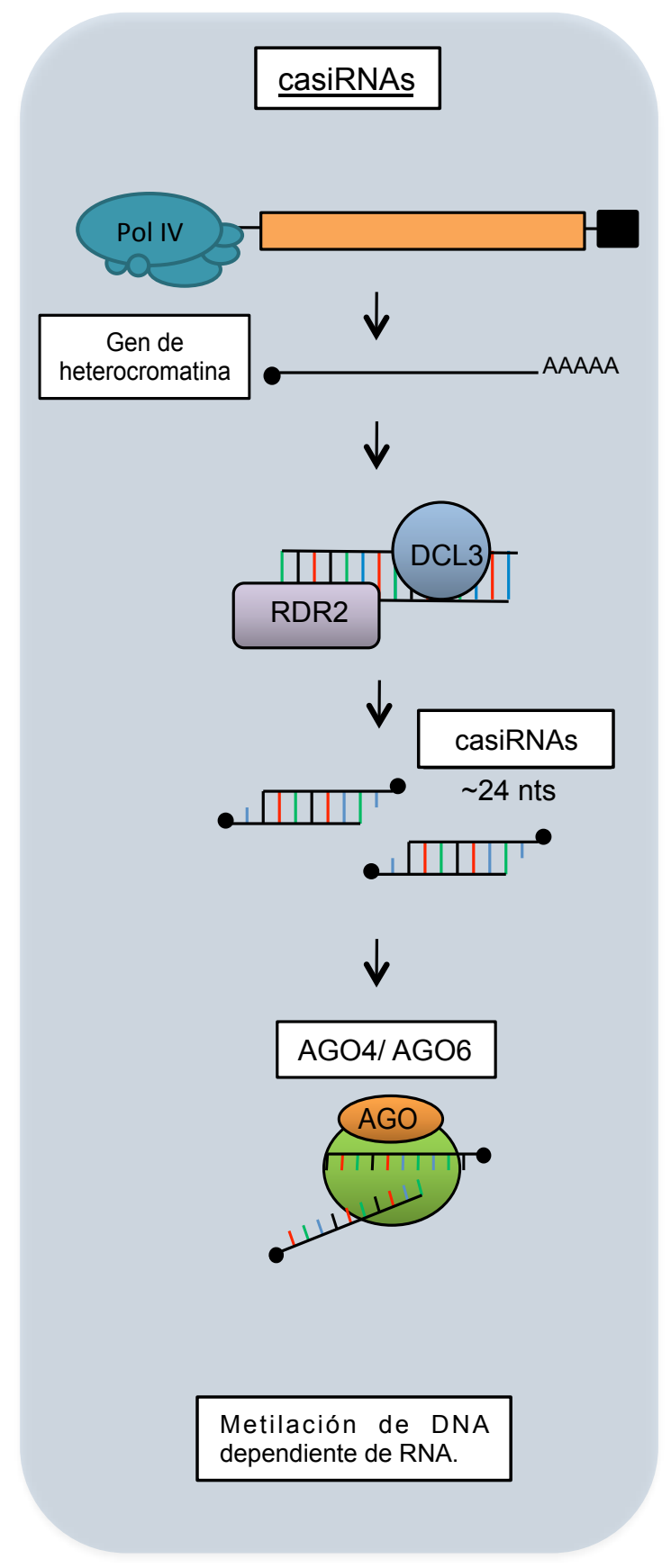

Figura 1.2. Representación esquemática de la ruta de biogénesis de casiRNAs.

Los trans-acting siRNAs (tasiRNAs) son una fracción minoritaria en el conjunto de siRNAs de la planta pero ejercen funciones esenciales en el control de genes de desarrollo y respuesta a estrés (Yoshikawa et al., 2005). Se originan a partir de RNAs (mensajeros no codificadores de genes nucleares denominados TAS (Allen et al., 2005; Yoshikawa, 2013). Los transcritos de los genes TAS tienen la particularidad de poseer uno o dos sitios de reconocimiento de miRNAs. Por ejemplo, el transcrito del gen TAS3 
posee dos sitios de unión complementarios al complejo miR390-AGO7 (Adenot et al., 2006). Estos complejos guían el corte endonucleolítico del transcrito diana en la zona de complementariedad. Tras el corte, el RNA resultante, que carece de extremos poliadenilados en 3' o caperuza en 5', sirve de molde para la síntesis de RNAs bicatenarios a través de enzimas RNA polimerasa dependiente de RNA (RDR) (Vazquez et al., 2004). Los RNAs de doble cadena producidos son digeridos a intervalos de 21 nts por enzimas DCL en asociación con la proteína DOUBLESTRANDED RNA BINDING PROTEIN 4 (DRB4) (Adenot et al., 2006). El procesamiento ocurre desde el extremo terminal de acuerdo con un registro de fase que viene definido por el sito inicial de corte del miRNA (Axtell et al., 2006). Curiosamente son los miRNAs de 22 nts, pero no los de 21 nts, los que poseen la capacidad para estimular la síntesis de estos siRNAs secundarios (Chen et al., 2010).

Una vez generados, los tasiRNAs median la degradación de sus RNAs mensajeros diana y/o la inhibición de su traducción, asociándose a complejos inductores del silenciamiento a través de las proteínas AGO1 o AGO7 (Figura 1.3) (Baumberger and Baulcombe, 2005; Montgomery et al., 2008a; Qu et al., 2008). Algunos miRNAs son también capaces de estimular la biogénesis de siRNAs secundarios a partir de elementos transponibles reactivados transcripcionalmente. Estos siRNAs se denominan siRNA activados epigenéticamente (ea-siRNAs, del inglés epigenetically-activated siRNAs) y su síntesis sigue una ruta genética similar a la de los tasiRNAs (Creasey et al., 2014). 


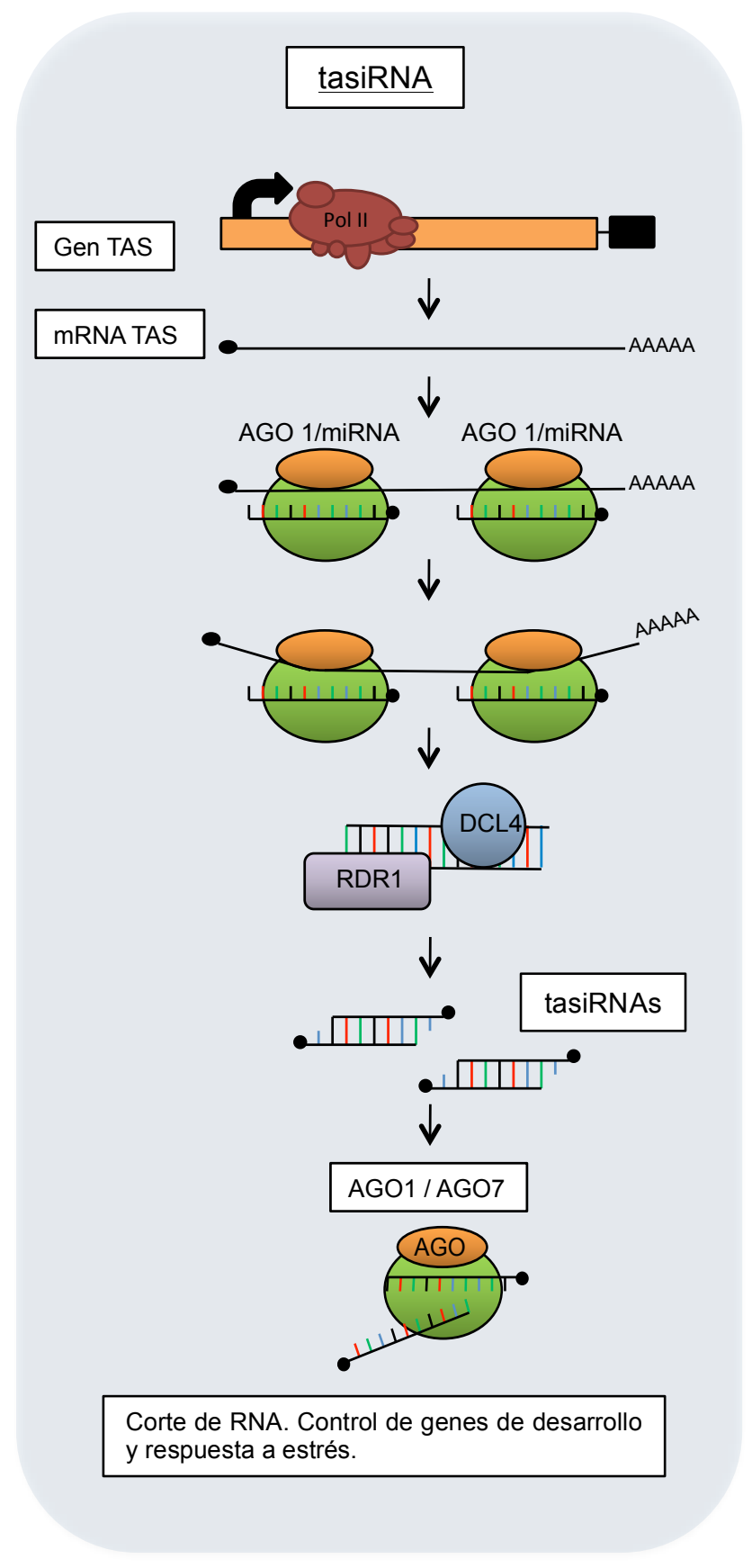

Figura 1.3. Representación esquemática de la ruta de biogénesis de tasiRNAs.

Los natsiRNAs se producen a partir de pares de genes convergentes conocidos como NAT (del inglés natural antisense transcripts) que al co-expresarse generan transcritos parcialmente complementarios sentido/antisentido en sus extremos (Borsani et al., 2005; Borges and Martienssen, 2015). El apareamiento intermolecular de ambos transcritos puede dar lugar a dsRNAs que actúan como iniciadores en la biogénesis de estos siRNAs. Los natsiRNAs se unen proteínas AGO para dirigir el corte endonucleolítico de transcritos con homología de secuencia (Borsani et al., 2005; Katiyar-Agarwal et al., 2006) (Figura 1.4). 


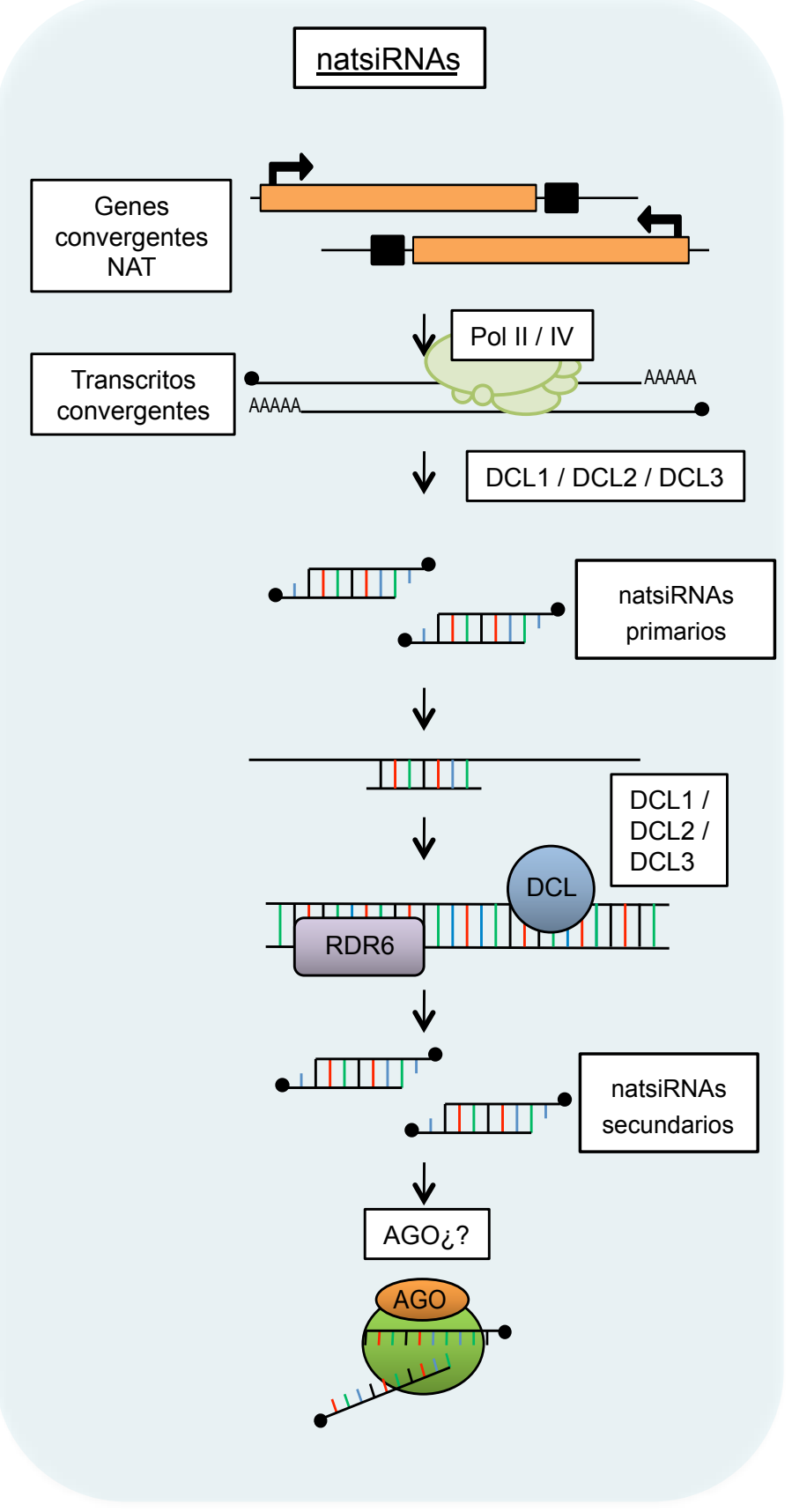

Figura 1.4. Representación esquemática de la ruta de biogénesis de natsiRNA en Arabidopsis.

\subsubsection{3. vasiRNAs}

En Arabidopsis la infección viral se asocia con la producción masiva de siRNAs endógenos derivados de regiones exónicas de más de 1000 genes de la planta y de RNA ribosómico (rRNA) (Cao et al., 2014). Estos siRNAs se conocen como siRNAs asociados a virus (vasiRNAs, del inglés viral-associated siRNAs) y tienen mayoritariamente una longitud de $21 \mathrm{nts}$ y la misma proporción de hebras sentido y antisentido (Cao et al., 2014). Los requerimientos genéticos para su biogénesis los hace 
diferentes del resto de siRNAs endógenos de plantas pero similares a los sRNAs de origen viral (vsRNAs, del inglés virus-derived small RNA) (Wang et al., 2010). Los vasiRNAs se detectan en las plantas de Arabidopsis inmediatamente tras la infección con virus aunque su producción puede verse afectada por proteínas virales supresoras del silenciamiento (Cao et al., 2014). Los vasiRNAs parece que tienen potencial de unirse a los complejos RISC y promover el autosilenciamiento de los RNAs mensajeros de los que proceden (Cao et al., 2014) (Figura 1.5).

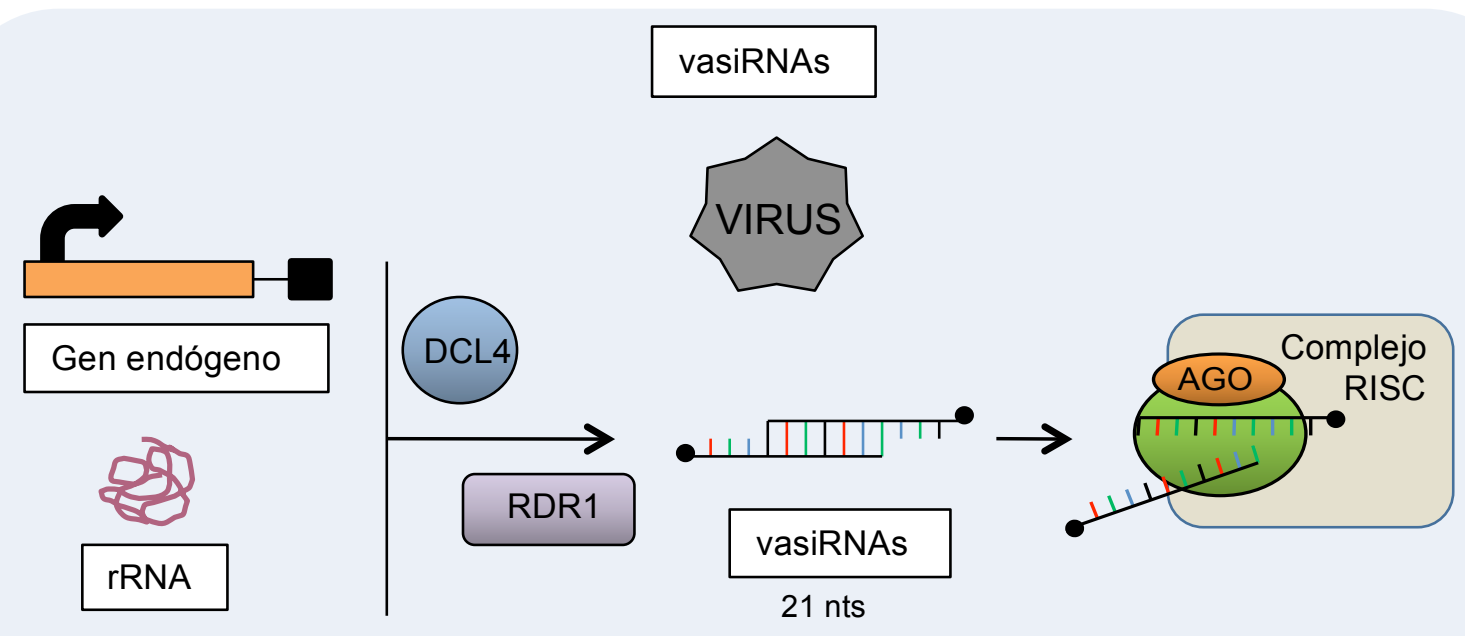

Figura 1.5. Representación esquemática de la ruta de biogénesis de vasiRNAs en Arabidopsis.

\subsubsection{Proteínas implicadas en la biogénesis de sRNAs}

\subsubsection{Proteínas DCL}

Las enzimas DCL son una clase de RNasa tipo III que emplea como sustrato moléculas de dsRNA. Las proteínas DCL actúan reconociendo los extremos de dsRNAs procesándolos secuencialmente para producir sRNAs maduros de 20 a $24 \mathrm{nts}$ (Margis et al., 2006; MacRae et al., 2007). Las proteínas DCL poseen un dominio N-terminal DExD helicasa/ATPasa, un dominio DUF283, un dominio PAZ, dos dominios catalíticos RNasa III (RNasa IIIa y RNasa IIIb) y un dominio C-terminal de unión al dsRNA (dsRBD, del inglés dsRNA-binding domain). El dominio dsRBD no aparece en todas las proteínas DCL por lo que podría mediar la especificidad de sustrato y su unión (Margis et al., 2006).

La estructura molecular de las proteínas DCL está altamente conservada por lo que en plantas podría aplicarse el modelo descrito a partir de la proteína Dicer de Giardia intestinalis. Este modelo demuestra que la longitud de los sRNAs producidos desde el extremo del dsRNA se corresponde con la distancia entre el sitio activo del dominio 
RNasa IIIa y el dominio PAZ, a su vez determinada por la longitud de la $\alpha$-hélice que los conecta (Macrae et al., 2006).

Arabidopsis cuenta con cuatro genes que codifican enzimas DCL. DCL1 produce miRNAs de 21 a 22 nts a partir de RNAs de cadena con estructura secundaria estable. DCL2, DCL3 y DCL4 sintetizan distintas subclases de siRNAs de 21 a 24 nts, llegando incluso a competir entre ellos por los mismos sustratos de RNA bicatenario (Kasschau et al., 2007). DCL3 es la principal enzima responsable de la síntesis de casiRNAs, aunque es capaz de interaccionar con ciertos precursores de miRNAs para generar miRNAs no canónicos de 24 nts (Moazed, 2009; Fukudome and Fukuhara, 2017). La actividad RNasa III de DCL4 libera siRNAs de 21 nts. Esta enzima participa en la biosíntesis de tasiRNAs y ea-siRNAs, de vasiRNAs y de siRNAs de origen viral (Brodersen and Voinnet, 2006; Xie and Qi, 2008). DCL4 está también implicada en la formación de miRNAs cuya aparición en la escala evolutiva ha sido relativamente reciente. Estos miRNAs proceden de estructuras precursoras largas y con alto grado de apareamiento que recuerdan a los RNAs bicatenarios resultantes de la transcripción de duplicaciones invertidas en el genoma (Allen et al., 2004). Excepcionalmente, en respuesta a la infección viral, se ha descrito que DCL4 puede cortar secuencialmente estructuras precursoras conservadas de miRNAs para generar miRNAs con registro de fase (Liu et al., 2009; Fukudome and Fukuhara, 2017). DCL2 produce siRNAs de 22 nts y se ha considerado tradicionalmente como una proteína subordinada a DCL4 en la biosíntesis de siRNAs virales y tasiRNAs (Xie et al., 2004). Aunque la función de ambas es a menudo redundante, DCL2 es esencial en la producción de natsiRNAs a partir de transcritos convergentes y de siRNAs secundarios derivados de transgenes (Borsani et al., 2005).

Los siRNAs resultantes de la actividad de las enzimas DCL poseen 2 nts desapareados en el extremo 3', con un grupo 5'monofosfato y un grupo hidroxilo en 3' (Zamore et al., 2000; Elbashir et al., 2001). En Arabidopsis las proteínas DCL se expresan de forma ubicua y constitutivamente en toda la planta, sin embargo, cada gen tiene un patrón de expresión diferencial en los distintos tejidos lo que podría explicar su diversidad funcional (Liu et al., 2009; Fukudome and Fukuhara, 2017).

\subsubsection{Proteínas RDR}

Las moléculas de RNA de doble cadena que inducen el silenciamiento por RNA pueden tener varios orígenes, pero generalmente son el resultado de la actividad de enzimas RDR con actividad RNA polimerasa dependiente de RNA (Baulcombe, 2004; Wassenegger and Krczal, 2006; Willmann et al., 2011). Estas enzimas convierten el RNA de cadena sencilla en dsRNA sintetizando una copia del RNA molde (Schiebel et 
al., 1998; Curaba and Chen, 2008). En Arabidopsis se han identificado seis genes que potencialmente codifican proteínas RDR. Tres de ellas: RDR1, RDR2 y RDR6 poseen en el extremo C-terminal un motivo catalítico canónico DLDGD que se encuentra en otras RNA polimerasas dependientes de RNA (Makeyev and Bamford, 2002; Wassenegger and Krczal, 2006). Las proteínas RDR1, RDR2 y RDR6 participan en distintas rutas de silenciamiento por RNA generando las estructuras de dsRNA que actúan como sustrato de las proteínas DCL (Willmann et al., 2011). Estas enzimas son críticas en la biosíntesis de siRNAs implicados en procesos de metilación del DNA dependiente de RNA (RDR2), en la síntesis de tasiRNAs y otros siRNA endógenos (RDR6) y en la formación de siRNAs a partir de RNAs virales (RDR1, RDR2 y RDR6) (Howell et al., 2007; Donaire et al., 2008; Montgomery et al., 2008b; Matzke et al., 2009; Matzke and Mosher, 2014; Leibman et al., 2018). RDR6 parece tener afinidad por moldes de RNA con características aberrantes, como por ejemplo la ausencia de caperuza en el extremo 5', mientras que la actividad de RDR2 parece asociarse con transcritos sintetizados por la RNA polimerasa IV (Pol IV). Las proteínas RDR3, RDR4, y RDR5 de Arabidopsis poseen en su centro catalítico un motivo atípico DFDGD (Willmann et al., 2011). Estas tres proteínas apenas están caracterizadas pero la existencia de homólogos en el genoma de otras plantas y hongos sugiere que pueden tener una función importante (Wassenegger and Krczal, 2006; Willmann et al., 2011).

\subsubsection{Proteínas implicadas en la actividad de los SRNAs}

\subsubsection{Proteínas AGO}

Las proteínas de la familia génica AGO son las principales proteínas efectoras en las rutas de silenciamiento guiadas por sRNAs (Meister, 2013). Su origen es ancestral y se encuentran presentes en bacterias, arqueas y eucariotas (Cerutti and Casas-Mollano, 2006). Las proteínas AGO son proteínas de 90-100 kDa que contienen los dominios funcionales PAZ, MID y PIWI (Tolia and Joshua-Tor, 2007; Hutvagner and Simard, 2008; Vaucheret, 2008). Los dominios MID y PAZ unen el nucleótido monofosforilado en 5' y el nucleótido en 3'del sRNA, respectivamente, formando así un bolsillo con el dominio PIWI que ancla el sRNA (Jinek and Doudna, 2009). El dominio PIWI posee actividad RNasa $\mathrm{H}$ y es el responsable del corte endonucleolítico sobre el mRNA diana en el centro de la región de complementariedad con el correspondiente sRNA (Liu and Paroo, 2010; Mallory and Vaucheret, 2010).

En plantas el número de homólogos en cada especie es muy variable (Fang and Qi, 2016). En Arabidopsis se han identificado diez genes aunque no se conoce aún la función de todas las proteínas que codifican. Entre ellas, AGO1, AGO2, AGO4, AGO7 y AGO10 median el corte endonucleolítico de moléculas de RNA diana a través del 
dominio catalítico PIWI resultando claves en el desarrollo vegetal y la defensa antiviral (Baumberger and Baulcombe, 2005; Qi et al., 2005; Qi et al., 2006; Montgomery et al., 2008a; Zhu et al., 2011; Carbonell et al., 2012). AGO4 y AGO10 actúan preferentemente como guías para el reclutamiento de metiltransferasas en las regiones complementarias del DNA diana (Qi et al., 2006; Zhu et al., 2011). AGO6 se asocia también con el silenciamiento transcripcional y aunque estudios iniciales la relacionaban con una función redundante con AGO4, más recientemente se ha propuesto que AGO4 y AGO6 ejercen funciones coordinadas en el proceso de metilación (Havecker et al., 2010; Duan et al., 2015). Además AGO6 presenta algunas funciones específicas como la asociación con un grupo específico de sRNAs heterocromáticos o su expresión mayoritaria en meristemos apicales y radiculares (Vaucheret, 2008; Havecker et al., 2010; Mallory and Vaucheret, 2010).

Experimentos de inmunoprecipitación de las distintas proteínas AGO en Arabidopsis han revelado que tanto el nucleótido en posición 5' como la longitud del sRNA determinan la unión selectiva de los RNAs con las distintas proteínas AGO. AGO4, AGO6 y AGO2 unen preferentemente sRNAs de 24 nts con adeninas en el extremo 5'terminal (Kim, 2008). AGO1 se une a miRNA procesados por DCL1 y a varias clases de siRNAs incluidos los siRNAs procedentes de transgenes, vsRNAs y tasiRNAs y tiene preferencia por los sRNAs de 21 a 22 nts con uridinas en el extremo 5 'terminal (Baumberger and Baulcombe, 2005). AGO10 presenta funciones redundantes con AGO1 y también se une preferentemente a sRNAs con uridinas en 5' (Mallory and Vaucheret, 2010; Ji et al., 2011; Garcia-Ruiz et al., 2015).

\subsection{Mecanismos efectores de silenciamiento génico}

\subsubsection{Silenciamiento post-transcripcional}

El silenciamiento génico post-transcripcional ocurre como consecuencia del corte endonucleolítico del RNA mensajero diana y la posterior degradación de los fragmentos resultantes por enzimas exonucleasas (Llave et al., 2002; Ruiz-Ferrer and Voinnet, 2009). El corte mediado por proteínas AGO con actividad ribonucleasa suele producirse entre las bases 10 y 11 (contando desde el extremo 5' del sRNA) en la región de complementariedad entre la secuencia diana y el sRNA correspondiente (Qi et al., 2005). La interacción funcional entre ambos requiere de un alto grado de apareamiento entre bases, especialmente en la denominada región "semilla" (en inglés, seed region) que comprende las posiciones nucleotídicas 2 y 13 en la zona apareada. Los productos 5' y 3' resultantes del corte endonucleolítico del transcrito diana contienen extremos 5' monofosfato y $3^{\prime}$ hidroxilo respectivamente, lo cual los diferencia de los productos de degradación por exonucleasas que poseen un grupo hidroxilo $5^{\prime}$ terminal y un fosfato en 
su extremo 3' (Ramachandran and Chen, 2008). El fragmento 3' del transcrito resultante es degradado en sentido 5'-3' por la enzima EXORIBONUCLEASE 4 (XRN4s), mientras que el fragmento $5^{\prime}$ es degradado por el complejo multiproteico del exosoma (Ramachandran and Chen, 2008).

La interacción funcional entre miRNAs y sus transcritos diana resulta con frecuencia en la inhibición de la traducción (Brodersen and Voinnet, 2006; Brodersen et al., 2008). El mecanismo inhibidor no se conoce con precisión pero parece que AGO1 puede dirigir tanto el corte del RNA mensajero como bloquear su traducción. Ambos mecanismos parecen no ser excluyentes y probablemente coexisten en la misma célula, aunque pudieran existir factores que determinen la prevalencia de uno sobre otro (Brodersen and Voinnet, 2006). Tradicionalmente se ha propuesto que el grado de complementariedad definido por el número $\mathrm{y}$ posición de apareamientos $\mathrm{y}$ desapareamientos en el par miRNA:diana pudiera determinar el sentido de la interacción (Llave et al., 2002). De este modo una alta complementariedad favorecería el corte específico de secuencia mientras que un elevado número de desapareamientos conduciría a la inhibición de la traducción (Brodersen et al., 2008). No obstante, esta teoría carece de evidencias sólidas que la fundamenten. Por ejemplo, el miR172 posee complementariedad casi perfecta con transcritos de APETALA 2 (AP2) pero en su modo de acción prevalece la inhibición traduccional frente a la degradación de los RNA mensajeros (Wu et al., 2009). El efecto inhibidor de la traducción parece asociarse con reorganizaciones dinámicas de la red de microtúbulos de la célula, y con la presencia de miRNAs y AGO1 en polisomas (Brodersen et al., 2008).

\subsubsection{Silenciamiento transcripcional}

El silenciamiento génico transcripcional implica alteraciones en la cromatina por metilación del DNA y/o sus histonas. En plantas la metilación del DNA se produce principalmente en elementos transponibles y en secuencias repetidas de ahí su relevancia como estabilizador del genoma de la planta (Dowen et al., 2012; Yu et al., 2013). El proceso conocido como metilación de DNA dependiente de RNA (RdDM, del inglés RNA-directed DNA methylation) es clave en la iniciación de la metilación (Matzke and Mosher, 2014) e implica la transcripción inicial a cargo de la Pol II de un locus del DNA sin marcas epigenéticas, la copia a dsRNA por la proteína RDR6 y la síntesis de siRNAs a cargo de las proteínas DCL2, DCL3 o DCL4 (Matzke et al., 2007; Matzke and Mosher, 2014). Estos siRNAs se asocian con AGO4 actuando como determinantes de especificidad para los complejos de silenciamiento y metilación. De forma independiente, los transcritos de Pol II pueden asociarse directamente con AGO4 y ser procesados por una exonucleasa específica que los corta en sentido $3^{\prime}-5^{\prime}$ 
generando siRNAs de 20 a $60 \mathrm{nts}$ de longitud denominados siRNAs independientes de DCL (sidRNAs, del inglés siRNAs independent of DCLs) (Matzke and Mosher, 2014; Ye et al., 2016). Los complejos cargados en AGO4 aparean con el transcrito naciente de la Pol II y guían a la metiltransferasa DOMAINS REARRANGED METHYLTRANSFERASE 2 (DRM2) a regiones del DNA complementarias (Ye et al., 2016). La metilación inicial del DNA promueve la transcripción dependiente de Pol IV y la activación de la ruta canónica de RdDM. En ella, los transcritos de la Pol IV son copiados a dsRNA por RDR2 y procesados por DCL3 a siRNAs de $24 \mathrm{nts}$ (Wierzbicki et al., 2012). Los transcritos de Pol IV también pueden interaccionar directamente con la proteína AGO4 y ser cortados en sidRNAs (Qi et al., 2006; Mosher et al., 2008). Los transcritos nacientes de Pol V actúan como un andamio de RNA que interacciona con AGO4 y AGO6 y guían a la metiltransferasa DRM2 a reforzar la metilación del DNA en ambas hebras (Wierzbicki et al., 2009; Liu et al., 2018). AGO4 co-localiza con la Pol II mientras que AGO6 se asocia con Pol IV, lo que ha llevado a proponer que ambas proteínas AGO actúan de forma secuencial durante el silenciamiento transcripcional de sus genes diana (Zilberman et al., 2003; Zheng et al., 2007).

En plantas, la metilación de citosinas puede darse en tres contextos de secuencia diferentes: $\mathrm{CG}$ y/o CHG (contexto simétrico) y $\mathrm{CHH}$ (contexto asimétrico), donde $\mathrm{H}$ representa cualquier nucleótido excepto la guanina (Matzke et al., 2007; Law and Jacobsen, 2010). Se han descrito tres metiltransferasas diferentes que median la transferencia de grupos metilo: DRM2, DNA METHYLTRANSFERASE 1 (MET1) y CHROMOMETHYLASE 3 (CMT3) (Finnegan and Kovac, 2000; Cao and Jacobsen, 2002). Las enzimas DRM se requieren para el establecimiento inicial de la metilación en todos los contextos de secuencia mientras que MET1 y CMT3 catalizan el mantenimiento de la metilación establecida previamente en el DNA en los contextos CG y CHG respectivamente (Finnegan and Dennis, 1993; Finnegan and Kovac, 2000; Lindroth et al., 2001; Zhong et al., 2014). El mantenimiento de la metilación en el contexto asimétrico $\mathrm{CHH}$ implica eventos de metilación de novo dependientes de siRNAs y la participación de DRM2 (Law and Jacobsen, 2010) y CMT2 (Zemach et al., 2013; Stroud et al., 2014) (Figura 1.6). 

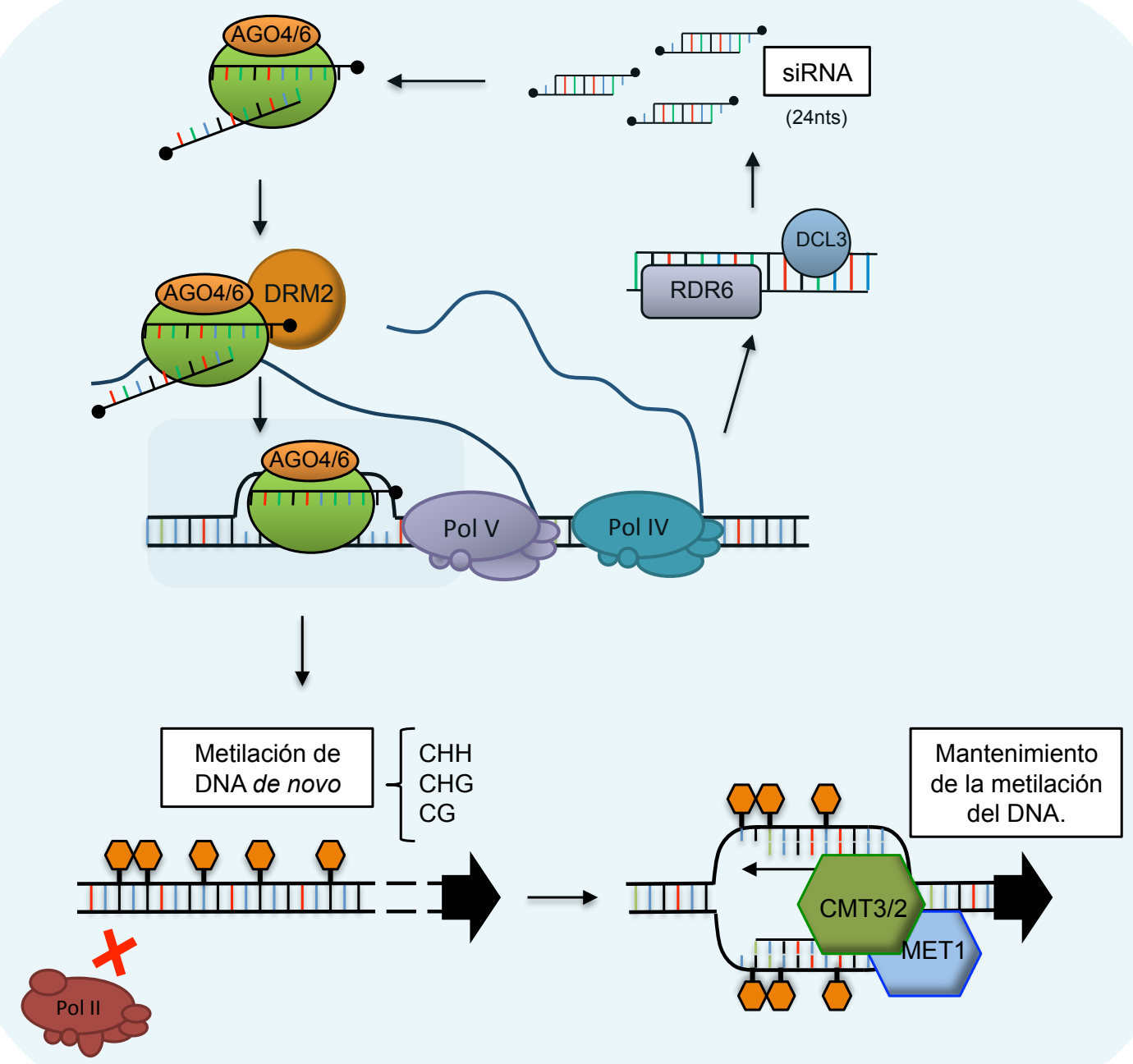

Figura 1.6. Representación esquemática del proceso de silenciamiento transcripcional en Arabidopsis.

\subsection{Inmunidad basal y virus}

Tradicionalmente se ha considerado la inmunidad innata como la principal barrera defensiva frente a hongos, bacterias y oomicetos patógenos. En las infecciones por virus, el rol de la inmunidad innata en la defensa antiviral parece limitarse a las respuestas tipo ETI (Mandadi and Scholthof, 2013). Esta respuesta ETI se activa cuando las proteínas NB-LRR de resistencia del huésped reconocen específicamente proteínas de avirulencia (Avr) de origen viral. Se inicia entonces una respuesta HR de muerte celular que sirve para confinar al virus en el foco de infección (Caplan et al., 2008). Al igual que ocurre con los efectores microbianos, las proteínas Avr virales son reconocidas por factores de resistencia en los huéspedes resistentes pero no en los susceptibles. En las plantas susceptibles estas proteínas son capaces de suprimir la respuesta inmune de la planta y facilitar la infección (de Ronde et al., 2014). 
Actualmente se conocen múltiples evidencias experimentales que sugieren que la respuesta PTI podría también contribuir de forma activa a la defensa antiviral (Korner et al., 2013; Gouveia et al., 2016; Nicaise and Candresse, 2017). Un ejemplo de ello es que las infecciones compatibles en plantas conllevan un incremento en la expresión de genes relacionados con la respuesta PTI y otras vías de defensa mediadas por ácido salicílico (SA) (Whitham and Wang, 2004). Se ha descrito que la inactivación genética de $B A K 1$ se asocia con un aumento en la susceptibilidad de esas plantas a patógenos no sólo microbianos sino también virales (Korner et al., 2013). Además, las infecciones virales en las plantas inducen respuestas relacionadas con la inmunidad PTI dependiente de BAK1 tales como la activación de MAPKs, el incremento en la producción de etileno o la inhibición del crecimiento de la raíz (Korner et al., 2013; Gouveia et al., 2016; Nicaise and Candresse, 2017). Esto nos sugiere que alguna molécula asociada a la infección (de origen viral o inducida por el virus) tendría la capacidad de interaccionar con receptores de membrana PRR regulados por BAK1 e iniciar así una respuesta PTI.

Conceptualmente el silenciamiento génico puede enmarcarse en el contexto de la inmunidad innata si consideramos que el RNA viral puede activar una respuesta efectiva que restringe la proliferación del virus (Ding, 2010). En este modelo, los intermediarios virales de RNA bicatenario serían reconocidos como un PAMP por las enzimas DCL que actuarían como receptores PRR (Ding, 2010). De esta forma se dispararía una cascada de eventos que incluye la producción de siRNAs primarios y secundarios (por mediación de enzimas RDR), su incorporación a los complejos efectores de silenciamiento y la consiguiente degradación de los RNAs virales complementarios (Llave, 2010). A esta estrategia los virus han respondido desarrollando proteínas virales con actividad supresora para contrarrestar la barrera represora del silenciamiento de forma similar a como los efectores microbianos suprimen la inmunidad en su entrada al interior celular (Nakahara and Masuta, 2014). Algunos de estos supresores virales actúan como proteínas Avr e interaccionan con proteínas de resistencia NB-LRR del huésped para activar una respuesta ETI que finalmente provoca una reacción HR.

\subsection{Mecanismos de silenciamiento génico y respuesta inmune}

\subsubsection{Silenciamiento transcripcional y respuesta inmune}

Existen evidencias que atribuyen funciones de inmunidad a los cambios del estado de metilación del genoma y al silenciamiento transcripcional (Lopez et al., 2011; Matzke and Mosher, 2014). Por ejemplo durante la infección con la bacteria patógena Agrobacterium tumefaciens, que transfiere genes inductores de tumores al DNA de la célula infectada, se produce una hipermetilación global del genoma de la planta (Gohlke 
et al., 2013). Curiosamente las plantas que presentan mutaciones en genes implicados en el proceso de metilación del DNA muestran un mayor índice de tumores cuando son infectadas con Agrobacterium, lo que sugiere que la metilación actuaría en este caso como un mecanismo de defensa (Gohlke et al., 2013). Por otro lado la infección con baterías fitopatógenas, o simplemente el tratamiento con compuestos microbianos, desencadenan cascadas de señalización tipo PTI e inducen la hipo o hipermetilación en regiones concretas del genoma (Dowen et al., 2012; Yu et al., 2013). Estos cambios en el patrón de metilación del DNA del huésped también se han observado durante las infecciones virales y producen la reactivación de elementos transponibles de la planta (Ruiz-Ferrer, comunicación personal). La activación de los transposones incrementa la diversidad fenotípica ya que reactivan genes adyacentes donde estaba insertado el transposón a la vez que se altera el patrón de expresión de los genes cercanos al nuevo punto de transposición (Dowen et al., 2012; Yu et al., 2013). También existen evidencias que demuestran que la infección con algunos viroides provoca cambios en el patrón de metilación de la región promotora de genes ribosómicos acarreando una activación transcripcional (Martinez et al., 2014). Sin embargo no está claro cómo los cambios en los patrones de metilación del genoma del huésped afectan al desarrollo de la infección, o si constituyen en sí mismos un mecanismo de patogénesis. Sea como fuere, una mayor diversidad fenotípica aumenta el potencial de las plantas para adaptarse a situaciones de estrés.

\subsubsection{Silenciamiento post-transcripcional y respuesta inmune}

La regulación post-transcripcional dependiente de silenciamiento génico ha demostrado desempeñar un papel en la respuesta defensiva de tipo PTI y ETI frente a patógenos. Por ejemplo, se ha observado que la percepción de flagelina, un péptido microbiano que induce respuestas PTI, intensifica de manera específica la acumulación de miR393 en Arabidopsis (Navarro et al., 2006). Este miRNA tiene un efecto específico sobre la represión de los receptores de auxinas de tal manera que incrementa la resistencia del huésped a la bacteria. Otro ejemplo lo constituye la enzima AGO1 que en Arabidopsis regula la formación de depósitos de calosa y la expresión de genes de defensa que favorecen la resistencia frente a bacterias (Li et al., 2010).

El silenciamiento post-transcripcional previene la sobreacumulación de transcritos de genes de resistencia evitando que superen un umbral a partir del cual la eficacia biológica de la planta pueda verse comprometida. Tal es el caso del locus RECOGNITION OF PERONOSPORA PARASITICA 5 (RPP5) (Yi and Richards, 2007), que comprende un conjunto de genes parálogos de resistencia con funciones en inmunidad innata frente a hongos y bacterias fitopatógenas, entre ellos RPP4 y 
SUPPRESSOR OF NPR1-1 CONSTITUTIVE 1 (SNC1). Estos genes, que se regulan positivamente a nivel transcripcional, son sin embargo diana de silenciamiento posttranscripcional cuando se acumulan por encima de un umbral que compromete la viabilidad de la planta (Zhai et al., 2011; Boccara et al., 2014). De hecho, su expresión se acentúa en mutantes de silenciamiento o en presencia de proteínas virales con actividad supresora de silenciamiento. Por ello, se ha propuesto que el silenciamiento desempeña un papel crítico eliminando el excedente de transcritos de SCN1 y minimizando así los costes asociados con la sobreexpresión de genes $\mathrm{R}$ en el locus RPP5 que ocurre en respuesta a patógenos (Yi and Richards, 2007).

La implicación del silenciamiento como regulador negativo de la respuesta inmune queda también evidenciada por el hecho de que plantas de Arabidopsis deficientes en esta ruta muestran fenotipos de resistencia basal frente a bacterias patógenas que son el resultado de una respuesta PTI constitutiva en estos mutantes (Boccara et al., 2014). La base de esta resistencia radica en la regulación post-transcripcional dependiente de RDR6 de docenas de genes CC-NB-LRRs (CNLs), tanto de forma constitutiva como durante la activación de la respuesta PTI. Curiosamente, estos transcritos CNL son también diana de regulación del miR472, y de hecho su inactivación provoca el mismo fenotipo de resistencia basal que el observado en los mutantes rdr6-15. Por el contrario, la sobreexpresión transgénica de miR472 se asocia con una mayor susceptibilidad a la infección (Boccara et al., 2014). En plantas de tomate se han descrito dos miRNAs (miR482 y miR2118) que reconocen el motivo conservado "P-loop" en genes de resistencia NB-LRR (Shivaprasad et al., 2012). La interacción funcional entre ambos promueve la degradación de los transcritos diana y la formación mediada por RDR6 de siRNAs secundarios. Curiosamente, uno de estos siRNAs es capaz de interaccionar y regular RNA mensajeros de otros genes de defensa. Esta cascada de silenciamiento dirigida por miR482 está inhibida en plantas infectadas con virus o bacterias por lo que se ha sugerido que dicha vía permite la expresión de proteínas NB-LRR en presencia de patógenos (Shivaprasad et al., 2012). Estos trabajos ilustran la manera en que dos vías de silenciamiento post-transcripcional bien diferenciadas (miRNAs y amplificación dependiente de RDR) actúan de forma coordinada para modular las respuestas PTI y ETI. En Medicago truncatula, especie modelo en estudios con leguminosas, se han identificado tres familias de miRNAs de 22 nts que interaccionan específicamente con dominios conservados en multitud de genes NB-LRR de resistencia estimulando la producción de tasiRNAs (Fei et al., 2015). Se ha sugerido que estos siRNAs secundarios podrían facilitar interacciones simbióticas a través de la regulación de estos genes de defensa. Este mecanismo de control no es exclusivo de esta especie ya que en patata, especie modelo en interacciones con la micorriza, también se generan cantidades abundantes de tasiRNAs a partir de genes NB-LRR (Zhai et al., 2011). En otro estudio, 
se ha observado en cultivares de tomate resistentes a Fusarium oxysporum la represión de ciertos miRNAs (slmiR482f y slmiR5300) que regulan negativamente proteínas con dominios NB implicadas en resistencia frente a hongos. Estos miRNAs sin embargo se expresan a niveles normales en los cultivares susceptibles (Moneymaker) en los que reprimen activamente los genes $R$ (Ouyang et al., 2014).

\subsubsection{Silenciamiento génico inducido por virus}

Los virus de plantas activan la vía del silenciamiento génico mediante la formación de dsRNA y de vsRNAs (Ding and Voinnet, 2007). De este modo, los vsRNAs sintetizados a partir de RNA virales entran a formar parte de una matriz reguladora que actúa sobre los genomas de la planta y del virus (Dunoyer and Voinnet, 2005). Esto significa que los vsRNAs tienen el potencial de guiar el autosilenciamiento de los RNAs virales de los que proceden y limitar por tanto la infección viral (Ruiz-Ferrer and Voinnet, 2009), y por otro de modular la expresión del genoma del huésped a través de interacciones con secuencias complementarias de RNA y DNA de la planta (Dunoyer and Voinnet, 2005; Llave, 2010).

Brevemente, el silenciamiento génico inducido por virus se puede dividir en tres fases diferentes: iniciación, amplificación y dispersión sistémica (Ruiz-Ferrer and Voinnet, 2009; Ding, 2010; Llave, 2010). La iniciación comienza con la formación de dsRNAs a partir del genoma viral. Estas moléculas sirven de sustrato para las proteínas DCL que las procesan para producir vsRNAs primarios de 21 a 24 nts. En la fase de amplificación se producen vsRNAs secundarios procedentes de dsRNAs cuya síntesis depende de la acción de proteínas RDR del huésped. Estos vsRNAs secundarios se transportan célula a célula hasta llegar al floema a través del cual alcanzan tejidos distantes de la planta así amplificando la señal de silenciamiento (Dunoyer et al., 2010b; Dunoyer et al., 2010a; Molnar et al., 2010).

\subsubsection{Silenciamiento génico como mecanismo antiviral en plantas}

El genoma más frecuente entre los virus de plantas es de RNA de cadena simple (ssRNA) y polaridad positiva aunque también los hay con genoma de ssRNA de polaridad negativa, de dsRNA, de ssDNA o de dsDNA. La replicación del material genético de los virus de RNA se asocia a estructuras membranosas en el citoplasma de la célula huésped y requiere la acción de una RNA polimerasa vírica; por el contrario, los virus de ssDNA se replican en el núcleo de la célula infectada haciendo uso de la maquinaria celular. Los virus con genomas de dsDNA presentan una fase nuclear donde se lleva a cabo la transcripción y otra citoplásmica donde se multiplican las moléculas 
de dsDNA mediante una transcripción inversa por una DNA polimerasa dependiente de RNA viral (Hull et al., 1987).

Durante la replicación del genoma viral y la transcripción de sus RNA mensajeros se forman en la célula huésped intermediarios replicativos con estructura de RNA bicatenario que puede ser reconocidos por enzimas DCL (Llave, 2010). Con la consiguiente síntesis de vsRNAs se inicia una vía de silenciamiento que se ha interpretado tradicionalmente como un eficaz mecanismo de defensa antiviral en las plantas (Ding, 2010). Las plantas de Arabidopsis mutantes de pérdida de función de la proteína DCL4 son muy susceptibles a las infecciones por virus de RNA y DNA (Blevins et al., 2006; Donaire et al., 2008), lo que sugiere que DCL4 es la proteína DCL con mayor actividad antiviral. Además, el incremento en la acumulación viral en los mutantes $d c l 4-2$ se asocia normalmente con un aumento en la gravedad de los síntomas de la infección. La función antiviral de las proteínas DCL2 y DCL3 parece accesoria o subordinada a la actividad de DCL4 (Bouche et al., 2006; Wang et al., 2010). DCL1 regula negativamente la expresión de DCL3 y DCL4 por lo que en mutantes $d c l 1-1$ se observa una respuesta antiviral exacerbada (Blevins et al., 2006).

DCL1 actúa en el procesamiento de los transcritos primarios de virus de dsDNA como el virus del mosaico de la coliflor (Cauliflower mosaic virus, CaMV) cortando la región 35S y permitiendo su procesamiento por DCL4 y DCL3 (Blevins et al., 2006). Esta actividad facilitadora de DCL1 aparece de forma similar en el procesamiento de los transcritos de repeticiones invertidas durante su silenciamiento génico posttranscripcional pero no afecta a los virus de RNA, para los cuales la actividad antiviral de DCL1 parece ser meramente residual (Deleris et al., 2006; Moissiard and Voinnet, 2006).

Dado que las proteínas RDR de la planta refuerzan la respuesta primaria del silenciamiento a través de la amplificación de la síntesis de vsRNAs, los mutantes disfuncionales para una o varias RDR muestran una susceptibilidad alterada en algunas infecciones virales (Donaire et al., 2008; Garcia-Ruiz et al., 2010; Wang et al., 2010). El silenciamiento antiviral frente a algunos virus es dependiente de la actividad conjunta de al menos RDR1 y RDR6 (Garcia-Ruiz et al., 2010). Además los mutantes rdr1-1 o rdr6-15 presentan mayor susceptibilidad a la infección de ciertos virus de RNA mientras que dobles y triples mutantes que impliquen a las proteínas RDR1, RDR2 y RDR6 se asocian con una mayor susceptibilidad a la infección por TRV, el virus del mosaico del pepino (CMV, Cucumber mosaic virus) y TuMV (Donaire et al., 2008; Garcia-Ruiz et al., 2010; Wang et al., 2010).

Sin embargo, la correlación entre la acumulación de vsRNAs secundarios dependientes de RDR y silenciamiento antiviral no aparece siempre. Por ejemplo, 
RDR1, RDR2 y RDR6 coordinan el silenciamiento antiviral en hojas inoculadas con TuMV. Para restringir la acumulación de TuMV a las hojas inoculadas y que no invada hojas caulinares se necesita la actividad conjunta de RDR1 y RDR6 aunque RDR1 o RDR6 son suficientes para mantener la infección fuera de las inflorescencias (GarciaRuiz et al., 2010). Sin embargo, durante la infección únicamente RDR1 es crítica en la biogénesis de los vsRNAs derivados de TuMV. De esta forma la amplificación del silenciamiento antiviral podría depender también de variaciones en los niveles de vsRNAs primarios o en el patrón de expresión de las RDR en distintos tejidos (GarciaRuiz et al., 2010).

De las diez proteínas AGO descritas en Arabidopsis, AGO1 y AGO2 son las principales enzimas efectoras de silenciamiento con función antiviral frente a virus de RNA (Ruiz-Ferrer and Voinnet, 2009; Carbonell and Carrington, 2015). Las primeras evidencias demostraron que las plantas mutantes agol de pérdida de función eran más susceptibles a la infección por ciertos virus que los genotipos silvestres (Morel et al., 2002). Estos estudios sugerían que AGO2 cooperaba de forma no redundante con AGO1 en la defensa antiviral, actuando como segunda línea de defensa frente a virus como CMV o el virus del arrugado del nabo (TCV, del inglés Turnip crinkle virus) que suprimen la función de AGO1. Sin embargo, trabajos recientes confirman que AGO2, pero no AGO1, ejerce una función antiviral frente a TRV o TuMV (Harvey et al., 2011). Estudios genéticos han demostrado funciones antivirales para AGO5, AGO7 y AGO10 aunque su contribución es minoritaria (Carbonell and Carrington, 2015). Evidencias genéticas y bioquímicas también atribuyen a AGO4 un papel relevante en la defensa frente a virus de RNA (Brosseau et al., 2016). En Arabidopsis se ha demostrado que los vsRNA formados durante la infección pueden incorporarse a los complejos efectores de silenciamiento a través de su unión con al menos AGO1, AGO2, AGO5 y AGO10 (Carbonell et al., 2015). Estos complejos tienen por tanto el potencial de dirigir la degradación de secuencias virales complementarias fomentando su corte endonucleolítico o inhibiendo su traducción. No obstante, las evidencias experimentales de un procesamiento in vivo de RNAs virales por complejos AGO se limitan al efecto de AGO1 y AGO7 en la degradación de secuencias sensoras de RNA viral con alta y baja estructura secundaria, respectivamente (Qu et al., 2008). Para AGO2 también se ha demostrado que su función antiviral radica en la actividad ribonucleasa (Carbonell et al., 2012).

AGO4 y AGO6 desempeñan un papel en la defensa antiviral frente a virus con genoma de DNA (Raja et al., 2008; Ruiz-Ferrer and Voinnet, 2009; Brosseau et al., 2016). Por ejemplo, mutantes ago4-2 de Arabidopsis muestran un fenotipo hipersusceptible a la infección con geminivirus que se relaciona con una reducción en la metilación del DNA viral (Raja et al., 2008). Los virus de DNA forman episomas en el 
núcleo de la célula infectada y sus genomas están expuestos a la misma regulación epigenética que el genoma del huésped (Voinnet, 2005). Los virus con genoma circular ssDNA (por ejemplo la familia Geminiviridae) se replican formando minicromosomas de dsRNA cuyos productos transcripcionales están sometidos a silenciamiento transcripcional mediante la metilación de episomas y minicromosomas (Raja et al., 2008).

\subsubsection{Supresión del silenciamiento génico antiviral}

Para contrarrestar el efecto antiviral del silenciamiento por RNA los virus han desarrollado diferentes estrategias siendo la más extendida la producción de proteínas supresoras del silenciamiento génico (VSR, del inglés viral suppressor of RNA silencing) (Voinnet et al., 1999; Ruiz-Ferrer and Voinnet, 2007; Giner et al., 2010; Burgyan and Havelda, 2011). La mayoría de las VSR son proteínas multifuncionales que comparten su actividad supresora con otras funciones críticas para el virus como la replicación, el movimiento o la encapsidación (Burgyan and Havelda, 2011). Los VSR emplean diferentes estrategias para evadir o bloquear el silenciamiento génico. Pueden inactivar las proteínas efectoras AGO1 y AGO2 (como las proteínas P38 de TCV ó P25 de PVX) (Burgyan, 2008), interferir en la producción de siRNAs (como la proteína TAV de CaMV) (Li et al., 1999), bloquear la señal de amplificación del silenciamiento [como la proteína V2 del virus del enrollado amarillo de la hoja del tomate (TYLCV, del inglés Tomato yellow leaf curl virus)] (Wang et al., 2018), desestabilizar los sRNAs [como la proteína P126 del virus del mosaico del tabaco (TMV, del inglés Tobacco mosaic virus)] (Wang et al., 2012) o inhibir el mecanismo de RdDM (como las proteínas homólogas AC2/AL2/C2/L2 codificadas por begomovirus y curtovirus de la familia Geminiviridae) (Wang et al., 2005).

\subsection{Regulación de la respuesta inmune en las infecciones virales}

El silenciamiento génico parece también desempeñar un papel relevante en la regulación de la respuesta inmune en las plantas infectadas con virus (Mlotshwa et al., 2008; Ruiz-Ferrer and Voinnet, 2009). Una evidencia de ello es la existencia de dos miRNAs (miR6019 y miR6020) en $N$. tabacum que interaccionan con los transcritos TIR1-NB-LRR del gen $N$, receptor que confiere resistencia al TMV, reprimiendo su acumulación (Li et al., 2012). El miR6019 tiene un tamaño de 22 nts y su actividad sobre los transcritos diana estimula la producción dependiente de RDR6 y DCL4 de siRNAs secundarios. Cuando estos miRNAs se sobreexpresan en las plantas de tomate, disminuye la resistencia a TMV mediada por el gen $N$ lo que pone de manifiesto la importancia de la regulación de genes NB-LRR por miRNAs en la resistencia a la 
enfermedad en esta especie ( $\mathrm{Li}$ et al., 2012). Como se ha descrito en el apartado anterior, el miR482 de tomate, en condiciones normales de crecimiento y desarrollo, dirige la degradación de transcritos de genes $C C-N B-L R R$ y la posterior formación de siRNAs secundarios (Shivaprasad et al., 2012). Curiosamente las infecciones virales y bacterianas reprimen esta cascada de silenciamiento mediada por el miRNA lo que induce la expresión de los genes de resistencia. Esto sugiere que mientras el virus bloquea el silenciamiento génico a través de sus proteínas VSR se activa la síntesis de un conjunto de receptores inmunes que contribuyen a la defensa antiviral (Shivaprasad et al., 2012). Esto contrasta con el hecho de que la infecciones virales se asocien con la producción masiva de siRNAs a partir numerosos genes del huésped, lo que sugiere que la presencia del virus pone en marcha un programa de regulación que afecta a buena parte del transcriptoma de la planta (Cao et al., 2014). Por lo tanto, durante las infecciones con virus y bacterias, el silenciamiento génico adquiere un importante compromiso como modulador de la expresión génica, aunque su efecto sobre el desarrollo de la infección es todavía un misterio (Mlotshwa et al., 2008; Ruiz-Ferrer and Voinnet, 2009).

\subsection{Posibles mecanismos de activación de la inmunidad basal durante la infección viral}

A pesar de que las respuestas PTI parecen activarse durante la infección por virus, el origen de la cascada de señalización así como los receptores celulares implicados continúa siendo un misterio (Nicaise and Candresse, 2017). Dado que los virus son parásitos intracelulares es posible que el desencadenante de la respuesta inmune sea una señal conservada originada por la planta. Sin embargo no está claro cómo las plantas perciben el daño asociado a una infección viral.

Las infecciones virales llevan asociada una considerable reprogramación del contenido de metabolitos primarios y secundarios (Llave, 2016). El hecho de que los azúcares funcionen como moléculas señalizadoras para las vías de PTI y ETI en infecciones por patógenos invita a pensar que la percepción del virus pudiera relacionarse con la biosíntesis de ciertos metabolitos (Bolouri Moghaddam and Van den Ende, 2012). Precisamente la proporción de sacarosa y hexosas en la célula podría actuar como señal para disparar la síntesis de genes de defensa, entre ellos genes de síntesis de metabolitos con propiedades antimicrobianas. Las poliaminas también podrían actuar como señalizadores en la transducción de señales en la activación de la inmunidad promoviendo la expresión de genes asociados al estrés (Walters, 2003). Por ejemplo, las plantas de Arabidopsis que son defectivas en los genes de biosíntesis de la poliamina putrescina presentan una mayor susceptibilidad a la infección viral 
(Fernandez-Calvino et al., 2014). Por otro lado, el metabolismo de los lípidos y ácidos grasos, los cuales proporcionan energía y conforman las membranas intracelulares donde replican los virus de RNA, experimenta también importantes cambios durante una infección (Heaton and Randall, 2011). De hecho, durante la infección los virus interfieren con la biosíntesis y metabolismo de lípidos y ácidos grasos con el fin de provocar los cambios en la fluidez y plasticidad de la membrana necesarios para la correcta formación de los complejos de replicación (Llave, 2016). Además, se ha descrito que las plantas que contienen niveles reducidos de ácidos grasos insaturados presentan mayor resistencia a la infección viral, lo que sugiere un papel para estos compuestos en las cascadas de señalización de rutas de defensa (Fernandez-Calvino et al., 2014).

Que las infecciones virales producen alteraciones en el metabolismo es un hecho reconocido, sin embargo sigue siendo un misterio cómo estas alteraciones pueden disparar una cascada de señalización inmune. La sobreproducción de especies reactivas de oxígeno (ROS, del inglés reactive oxygen species) es una consecuencia de la inmunidad PTI y ETI, pero también es una respuesta común asociada al estrés ambiental y a las infecciones virales (Stael et al., 2015). Es posible que la biosíntesis de metabolitos protectores durante la infección sea una respuesta para aliviar el estrés ocasionado por la generación de ROS. Esto implicaría que la acumulación de azúcares, ácidos grasos insaturados o poliaminas con propiedades detoxificadoras sería posiblemente una consecuencia, y no la causa, de la activación de la respuesta inmune. Según esta idea, la infección confiere a la planta un estado de aclimatación metabólica que le permite sortear el estrés celular asociado a la infección, y por extensión, a otros estreses ambientales. Aunque el mecanismo de iniciación que producen estos compuestos sigue aún por determinar.

\subsection{Infecciones virales y senescencia en plantas}

Las plantas responden a la infección por patógenos reprogramando la expresión de sus genes. Este proceso incluye la inducción de genes relacionados con la defensa y la patogénesis (Dangl and Jones, 2001; van Loon et al., 2006; Wise et al., 2007). De forma similar, la activación de genes de defensa es una respuesta inherente al proceso de senescencia en plantas, lo que sugiere que ambos procesos están controlados genéticamente por eventos o vías de señalización comunes (Quirino et al., 1999; Lin and $\mathrm{Wu}, 2004)$. La senescencia es una forma de muerte celular programada activada por señales de desarrollo, físicas, fisiológicas y/o hormonales y que se ha considerado como un programa de reciclaje para la movilización de nutrientes (Quirino et al., 1999; Quirino et al., 2000; Buchanan-Wollaston et al., 2003; Gepstein et al., 2003; Lim and 
Nam, 2005). Aunque durante la senescencia declina el contenido total de proteínas y los niveles de RNA mensajeros disminuyen, se han identificado cientos de genes cuya expresión se regula positivamente durante el proceso (Quirino et al., 2000). Muchos de estos genes asociados a distintas formas de senescencia codifican proteínas de defensa, incluidas proteínas asociadas a la patogénesis (PR) típicamente relacionadas con la respuesta hipersensible o la resistencia sistémica adquirida (SAR, del inglés systemic acquired resistance) (Obregon et al., 2001). Este hecho ha llevado a sugerir que la senescencia se acompaña de infecciones oportunistas que activan un programa de defensa. Sin embargo, los genes de defensa también se activan en plantas senescentes cultivadas en condiciones estériles, lo que demuestra que su inducción es una parte integral del programa de senescencia y no la consecuencia de infecciones colaterales. Curiosamente, otros genes asociados a la senescencia también se activan durante el ataque por organismos patógenos, (Quirino et al., 1999; Obregon et al., 2001; Lin and $\mathrm{Wu}, 2004)$. Por ejemplo, algunos genes asociados a la senescencia se detectan durante la respuesta hipersensible contra bacterias y hongos incompatibles y contra patógenos virulentos o avirulentos que causan necrosis (Butt et al., 1998; Pontier et al., 1999; Schenk et al., 2005). Esta observación podría llevar a la suposición engañosa de que la muerte celular es el punto necesario de convergencia entre la defensa y la senescencia. Sin embargo, los genes relacionados con la senescencia también se expresan a niveles elevados durante las interacciones compatibles entre las plantas y los virus (Whitham et al., 2003 901; Espinoza et al., 2007 1808). Por lo tanto, la ejecución del programa de muerte celular parece estar desacoplada de la regulación inicial de la senescencia.

El estrés celular es el factor más probable que explica por qué los genes relacionados con la senescencia se activan durante el proceso de infección. De hecho, muchos genes inducibles por estrés se regulan positivamente durante la senescencia, lo que implica que las células sometidas a senescencia están sujetas a condiciones de estrés (Weaver et al., 1998; Gepstein et al., 2003). Además, el estrés causado por la sequía, la oscuridad, déficit de nutrientes, heridas o la caída de las hojas inician el programa de senescencia (Weaver et al., 1998; Lin and Wu, 2004). En este escenario, la pérdida de actividad fotosintética y la destrucción del cloroplasto que es común en plantas senescentes y en infecciones por virus y microbios se ha descrito como un posible inductor de senescencia.

La producción de ROS es una respuesta común a múltiples estreses $\mathrm{y}$, en consecuencia, se ha propuesto como una posible señal que controla la expresión de genes en plantas estresadas (Quirino et al., 2000; Love et al., 2005; Torres and Dangl, 2005). La senescencia y la infección por patógenos están acompañadas de cierto grado de daño celular causado por el estrés oxidativo y, por lo tanto, los genes de desintoxicación de ROS se estimulan en ambos tipos de procesos (Buchanan-Wollaston 
et al., 2003; Whitham et al., 2003; Espinoza et al., 2007; Schippers et al., 2008). Por ejemplo, la glutamato deshidrogenasa (GDH), que se activa tanto en la senescencia como en las infecciones virales o bacterianas, se expresa a altos niveles bajo estrés oxidativo (Pageau et al., 2006). Algunas hormonas implicadas en la transducción de señales en procesos de defensa frente a patógenos como el SA o el metil jasmonato (MeJA) también regulan la expresión de ciertos genes que promueven senescencia (Schenk et al., 2005). Además, los cambios en el balance fuente/sumidero normalmente asociados a las invasiones de patógenos también son fundamentales para regular la senescencia de las hojas (Herbers et al., 2000; Masclaux et al., 2000; Shalitin and Wolf, 2000; Quirino et al., 2001).

\subsection{Antecedentes y resultados previos}

Con el fin de estudiar el papel que el silenciamiento génico desempeña como mecanismo regulador en las interacciones planta-virus nos propusimos identificar a escala genómica los genes de la planta que pudieran ser dianas de regulación posttranscripcional dependiente de pequeños RNAs durante la infección. Para ello empleamos una tecnología conocida como "Procesoma" que nos permite reconocer aquellos genes cuyos RNAs mensajeros se degradan de forma selectiva bajo determinadas condiciones experimentales (Franco-Zorrilla et al., 2009). Esta metodología se basa en el aislamiento y amplificación de los productos de RNA resultantes de la actividad de enzimas RNasa que dejan extremos 5' monofosfato, y que incluyen RNAs sin caperuza 5' y RNAs degradados (Christie et al., 2011). Las genotecas de cDNA así generadas se hibridaron con micromatrices de Affymetrix para identificar aquellos genes enriquecidos en fragmentos de degradación. En nuestro ensayo encontramos 47 genes en plantas no infectadas de Arabidopsis y 98 genes en plantas infectadas sistémicamente con TRV que producían cantidades significativas de transcritos degradados. Estos genes se consideraron como potenciales dianas de silenciamiento. Entre los genes identificados en plantas control no infectadas, 8 correspondían con genes que se habían descrito previamente como dianas de microRNAs, mientras que 12 lo fueron en la lista de genes candidatos en plantas infectadas (Tabla 1.1). En ambos casos estos datos representaban un enriquecimiento en dianas validadas de 30 a 35 veces mayor que el esperado para el conjunto de genes representado en la micromatriz de Affymetrix (Figura 1.7). Comparando los resultados de plantas control sin infectar con los obtenidos en plantas infectadas con TRV fue posible confeccionar una lista de 22 genes candidatos cuyos transcritos se degradaban significativamente en presencia del virus pero no en plantas sin infectar (Tabla 1.1). Para reforzar nuestra predicción, llevamos a cabo un experimento de secuenciación de 
genotecas de degradoma (German et al., 2009). Esta metodología, complementaria al procesoma, permite el mapeo preciso de cada uno de los sitios de corte en un RNA mensajero determinado (Addo-Quaye et al., 2008; German et al., 2008). Estos sitios de corte están representados por el nucleótido 5' terminal de cada uno de los subproductos de RNAs resultantes de la degradación de dicho transcrito. De esta manera podemos representar en un gráfico la frecuencia de los sitios de corte (eje Y) y su distribución a lo largo del transcrito (eje X). El análisis de degradoma de los 22 genes seleccionados en nuestro estudio mostraba que 9 de ellos presentaban una o varias lecturas de corte muy abundantes en plantas infectadas, pero no en plantas control (Figura 1.8). La frecuencia de aparición de estas lecturas indicaba que se trataba de secuencias de corte preferencial a lo largo del transcrito en contraste con el fondo de lecturas de baja frecuencia observado en plantas control. Este fondo de lecturas representaba sitios de corte aleatorio a lo largo de la cadena de RNA mensajero. Estos resultados confirmaban que los transcritos identificados en nuestro análisis están sujetos a degradación posttranscripcional. 


\begin{tabular}{|c|c|c|c|c|c|c|c|c|}
\hline \multicolumn{2}{|c|}{$\begin{array}{l}\text { TRV-infected } \\
\text { inflorescences }\end{array}$} & \multicolumn{2}{|c|}{$\begin{array}{l}\text { Mock-inoculated } \\
\text { inflorescences }\end{array}$} & \multirow[b]{2}{*}{ ProbeID } & \multirow[b]{2}{*}{ TranscriptID } & \multirow[b]{2}{*}{ Gene Symbol | Gene Title } & \multirow[b]{2}{*}{ p-value } & \multirow[b]{2}{*}{$\log$ ratios } \\
\hline $\begin{array}{l}\text { Fold } \\
\text { Change }\end{array}$ & $\begin{array}{l}\text { FDR } \\
\text { (LiMMA) }\end{array}$ & $\begin{array}{l}\text { Fold } \\
\text { Change }\end{array}$ & $\begin{array}{l}\text { FDR } \\
\text { (LiMMA) }\end{array}$ & & & & & \\
\hline 3,86 & 0,00003696 & 2,65 & 0,01307831 & 266012_s_at & At2g07741 & pseudogene, similar to ATPase subunit 6 & 0,037924192 & 0,54 \\
\hline 3,61 & 0,0001409 & 2,4 & 0,00001861 & 250277_at & At5g 12940 & leucine-rich repeat family protein & 0,005070476 & 0,583333333 \\
\hline 2,83 & 0,00032397 & 2,1 & 0,00031342 & 246755_at & At5g27920 & F-box family protein & 0,046012535 & 0,43 \\
\hline 2,75 & 0,00013904 & 1,88 & 0,0008416 & 254852_at & At4g12020 & protein kinase family protein & 0,024162968 & 0,55 \\
\hline 2,48 & 0,00082427 & 1,37 & 0,15987759 & $248385 \_$at & At5g51910 & TCP family transcription factor & 0,046596341 & 0,856666667 \\
\hline 2,45 & 0,00103328 & 1,62 & 0,02047198 & 258368_at & At3g 14240 & subtilase family protein & 0,01801632 & 0,6 \\
\hline 2,42 & 0,00215504 & 1,64 & 0,0227108 & 249860_at & At5g22860 & $\begin{array}{l}\text { serine carboxypeptidase } \\
\text { protein }\end{array}$ & 0,003781195 & 0,563333333 \\
\hline 2,4 & 0,00138562 & 1,48 & 0,03150414 & 248698_at & At5g48380 & leucine-rich repeat family protein & 0,000534923 & 0,703333333 \\
\hline 2,38 & 0,00251755 & 1,11 & 0,65614239 & 251701_at & At3g56650 & thylakoid lumenal $20 \mathrm{kDa}$ protein & 0,026853584 & 1,09 \\
\hline 2,34 & 0,00063816 & 1,79 & 0,00417438 & 247319_at & At5g64050 & glutamate-tRNA ligase family protein & 0,033971041 & 0,386666667 \\
\hline 2,32 & 0,00239944 & 1,45 & 0,04254022 & 246079_at & At5g20450 & $\begin{array}{l}\text { expressed protein } \\
\text { stomatal cytokinesis defective / SCD1 }\end{array}$ & 0,014535515 & 0,68 \\
\hline 2,31 & 0,00037924 & 1,42 & 0,03634628 & 260751_at & At1g 49040 & protein & 0,001069835 & 0,706666667 \\
\hline 2,3 & 0,00070414 & 1,57 & 0,00942556 & 262060_at & At1g80170 & polygalacturonase/ pectinase & 0,02147944 & 0,546666667 \\
\hline 2,3 & 0,00037906 & 1,39 & 0,04194361 & 258185_at & At3g21580 & $\begin{array}{l}\text { cobalt ion transmembrane transporter } \\
\text { CAAX amino terminal protease family }\end{array}$ & 0,003751694 & 0,72 \\
\hline 2,22 & 0,00172017 & 1,48 & 0,02057841 & 261483_at & At1g14270 & protein & 0,036486281 & 0,586666667 \\
\hline 2,15 & 0,00086104 & 1,54 & 0,01379221 & 252941_at & At4g39280 & phenylalanyl-tRNA synthetase & 0,008645314 & 0,486666667 \\
\hline 2,11 & 0,00594562 & 1,29 & 0,14709984 & 264247_at & At1g60160 & potassium transporter family protein & 0,01320966 & 0,706666667 \\
\hline 2,05 & 0,01065134 & 1,15 & 0,43520101 & 257506_at & At1g29440 & auxin-responsive family protein & 0,027134122 & 0,84 \\
\hline 2,05 & 0,00745099 & 1,14 & 0,47707474 & 264141_at & At1g79090 & expressed protein & 0,040556493 & 0,843333333 \\
\hline 2,02 & 0,00821977 & 1,23 & 0,33526959 & 260143_at & Atlg71880 & $\begin{array}{l}\text { SUC1 | sucrose transporter } \\
\text { heat shock transcription factor family }\end{array}$ & 0,025263382 & 0,71 \\
\hline 2,02 & 0,00784467 & 1,01 & 0,96993336 & 260701_at & At1g32330 & protein & 0,002388233 & 0,996666667 \\
\hline 2,22 & 0,00166935 & 1,45 & 0,02921421 & 261800_at & At1g30490 & $\begin{array}{l}\text { Athb-9 } \mid \text { homeobox-leucine zipper } \\
\text { transcription factor (HB-9) }\end{array}$ & 0,034534688 & 0,62 \\
\hline
\end{tabular}

Tabla 1.1 Potenciales dianas de silenciamiento mediado por RNA detectadas en inflorescencias infectadas con TRV y controles inoculados con tampón. Los genes candidatos fueron identificados a través de la tecnología del "procesoma" seguida de la hibridación con micromatriz ATH1 de Affymetrix. La tabla contiene los genes diferencialmente expresados en las poblaciones ligadas al adaptador T7-RNA frente a los controles negativos (fold change $\geq 2$ y FDR $\leq 0,05$ ) para cualquiera de las muestras control o infectadas con TRV. Las columnas adicionales representan las dianas candidatas procesadas diferencialmente entre plantas control e infectadas con TRV ( $\log _{2}$ ratio[TRV/Mock]), y su correspondiente p-valor (F-test, con 1 y 4 grados de libertad).

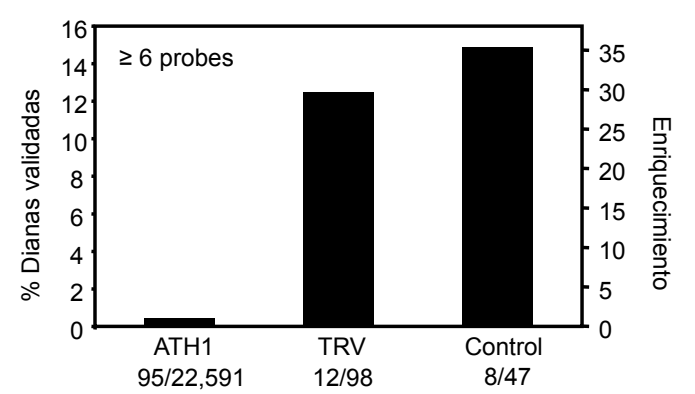

Figura 1.7. Identificación a escala global de las dianas de silenciamiento por RNA empleando la tecnología del "procesoma". Porcentaje de dianas de miRNA validadas y representadas en el microarrays ATH1 y en nuestras listas de genes con procesamiento diferencial entre plantas inoculadas con tampón e infectadas con TRV. 

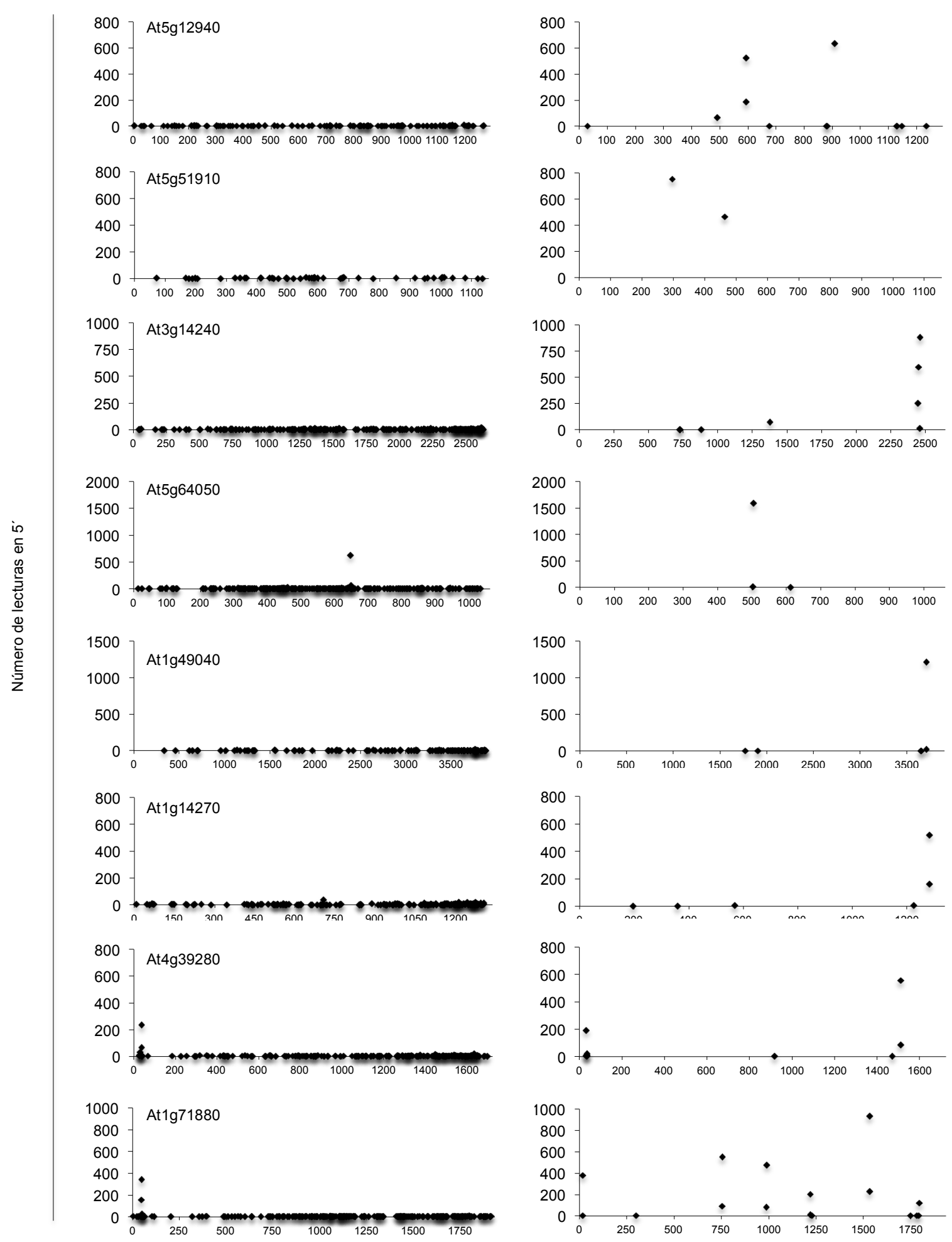

Figura 1.8. Perfil de degradoma de los genes procesados diferencialmente entre plantas control inoculadas con tampón e infectadas con TRV. Los gráficos de las dianas representan la abundancia de cada punto de corte en 5 'en función de su posición en el transcrito. Los picos de abundancia indican puntos de corte preferente y se encontraron en las muestras infectadas con TRV pero no en las muestras control. 
Entre los genes degradados de forma diferencial entre planta sana e infectada identificamos el locus At5g48380, que codifica la proteína BAK1-INTERACTING RECEPTOR-LIKE KINASE 1 (BIR1). BIR1 ha sido descrito como un regulador negativo de la respuesta inmune mediada por proteínas LRR-RLK y NB-LRR (Gao et al., 2009). La desactivación genética de BIRl en plantas mutantes birl-1 se asocia con defectos en el desarrollo y muerte celular, fenotipo que recuerda al observado en plantas con expresión constitutiva de genes de resistencia. De hecho, el fenotipo de muerte celular en el mutante bir1-1 depende parcialmente de PHYTOALEXIN DEFICIENT 4 (PAD4) y ENHANCED DISEASE SUSCEPTIBILITY 1 (EDS1), ambas necesarias para la función de proteínas R del tipo TIR-NB-LRR (Falk et al., 1999; Jirage et al., 1999; Gao et al., 2009). La activación permanente de las defensas en ausencia de patógenos compromete la eficacia biológica y la integridad de la planta por lo que es esencial que las vías de señalización de la respuesta inmune estén reguladas estrictamente (Yi and Richards, 2007; Zhai et al., 2011; Boccara et al., 2014). Puesto que la pérdida de función de $B I R 1$ moviliza constitutivamente rutas de defensa que también se activan durante la respuesta PTI y la resistencia mediada por proteínas $\mathrm{R}$, parece que la función de BIR1 es crítica para entender cómo las plantas evitan la activación de respuestas PTI y ETI en ausencia de ligandos microbianos.

SUPPRESSOR OF BIR1 1 (SOBIR1) se ha descrito como un regulador positivo de la muerte celular en Arabidopsis (Liu et al., 2016). SOBIR1 es también una RLK que interacciona con LRR-RLPs (que carecen de domino quinasa) contribuyendo a su función en procesos de inmunidad y desarrollo (Zhang et al., 2013; Sun et al., 2014; Liu et al., 2016). SOBIR1 se descubrió en un cribado genético de supresores del fenotipo de bir1-1, de ahí su denominación (Gao et al., 2009; Liebrand et al., 2014). La mutación sobirl-1 restaura el fenotipo silvestre de crecimiento y defensa en el mutante birl-1 ya que resulta en la supresión completa de la muerte celular, de la producción de peróxido de hidrógeno y de la expresión de genes PR (Gao et al., 2009) (Liu et al., 2016). De estos resultados se infiere que en las plantas sin función BIR1 se movilizan dos vías de señalización de defensa que promueven la muerte celular y la resistencia, una dependiente de SOBIR1 y otra dependiente de EDS1 y PAD4 (Gao et al., 2009; Liebrand et al., 2014).

BIR1 se localiza en la membrana plasmática donde interacciona físicamente con el regulador inmune BAK1 (Gao et al., 2009). Esta interacción es crítica para la regulación eficaz de la muerte celular y las defensas de la planta (Wierzba and Tax, 2016). BAK1 se identificó originalmente por interactuar con el receptor de brasinosteroides BRI1 y por su papel en el desarrollo de la planta en respuesta a esta hormona (Li et al., 2002; Nam and Li, 2002). Sin embargo, BAK1 desempeña funciones esenciales en la 
señalización inmune activada por diversos PAMPs (flagelina, EF-Tu, HrpZ, PGN y LPS) a través de su asociación con múltiples receptores PRRs (Chinchilla et al., 2007; Heese et al., 2007; Shan et al., 2008). BAK1 también es crítica en la regulación negativa de la muerte celular programada (He et al., 2007; Kemmerling et al., 2007). BAK1 no está directamente implicada en la percepción de estas señales pero su asociación con los receptores RLK es fundamental en la regulación de las consiguiente respuesta inmune (Kemmerling and Nurnberger, 2008). En ausencia de patógenos, se ha propuesto que la asociación de BIR1 con BAK1 impide la activación de vías de resistencia dependientes de PAD4 y de SOBIR1 (Gao et al., 2009; Ma et al., 2017). Solo en presencia de un ligando y de su unión con el receptor PRR correspondiente se produce el cambio conformacional que libera BAK1 permitiendo así la formación de los complejos BAK1receptor PRR y la consiguiente transducción de la señal inmune (Chinchilla et al., 2007; Heese et al., 2007; Kemmerling et al., 2007).

BAK1 interacciona constitutivamente en ausencia de ligandos con al menos otros dos miembros de la familia génica BIR en Arabidopsis (BIR2 y BIR3) (Halter et al., 2014a; Imkampe et al., 2017). Al igual que ocurre con BIR1, BAK1 rompe su unión con BIR2 o BIR3 en presencia de PAMPs para asociarse con el correspondiente receptor PRR. BIR2 es también crítico como regulador negativo de la respuesta PTI y de la muerte celular (Halter et al., 2014b). Por el contrario, BIR3 es esencial en el control de las repuestas PTI, pero su influencia sobre el control de la muerte celular es irrelevante (Imkampe et al., 2017). Al contrario que BIR1, BIR2 carece de actividad quinasa, lo que sugiere que ambas RLKs actúan de acuerdo a mecanismos diferentes (Halter et al., 2014b). Estos datos sugieren que la regulación negativa que ejercen los genes $B I R$ ocurre a varios niveles y a través de diversos mecanismos que garantizan un control fino y equilibrado en la activación y desactivación de la respuesta inmune mediada por RLKs.

No parece que BIR1 esté implicado en la percepción de señales extracelulares, si bien no se descarta que pudiera sentir señales endógenas ya que la muerte celular en mutantes birl-1 ocurre incluso en condiciones de esterilidad (Gao et al., 2009). Esta observación es relevante ya que los virus no producen compuestos que pudieran catalogarse como PAMPs en sentido estricto. Aunque tradicionalmente se ha asumido que la respuesta inmune frente a los virus implica esencialmente el reconocimiento de efectores virales por factores de resistencia intracelulares (Zvereva and Pooggin, 2012), diversos trabajos sugieren que la inmunidad basal o PTI desempeña un papel importante en la defensa antiviral (Korner et al., 2013; Gouveia et al., 2016; Nicaise and Candresse, 2017). Estudios recientes demuestran que la infección compatible de varios virus induce la expresión de genes de defensa lo cual indica que las plantas también reconocen a los 
virus a través de la respuesta PTI (Korner et al., 2013; Nicaise and Candresse, 2017). En uno de estos trabajos el mutante deficiente en $B A K 1$ presenta mayor susceptibilidad a las infecciones virales que el fondo silvestre (Korner et al., 2013). También se ha descrito que algunos virus de plantas han adquirido la habilidad de suprimir etapas iniciales de la respuesta PTI como contrapartida a esta línea de defensa (Nicaise and Candresse, 2017). A pesar del papel crítico que desempeñan estos elementos en el control del inicio de la cascada de señalización que culmina en la respuesta inmune, nuestro conocimiento de sus mecanismos de regulación es muy limitado hasta el momento.

La senescencia es un proceso que se induce en respuesta a estreses bióticos y abióticos (Quirino et al., 2000). Trabajos previos han demostrado la activación de genes asociados a procesos de senescencia en plantas infectadas por virus (Whitham et al., 2003; Fernandez-Calvino et al., 2014). Incluso procesos asociados con la senescencia como la desorganización de los cloroplastos, o la disminución de las actividades metabólicas celulares recuerdan a lo observado en plantas infectadas con virus (Llave, 2016). Independientemente de su función, la activación de genes comunes en dos situaciones claramente distintas como son la respuesta a la infección por virus y la senescencia se puede interpretar como una indicación de que ambos procesos, aparentemente no relacionados, están en realidad interconectados.

Para determinar si la infección por TRV en plantas de Arabidopsis provocaba cambios en la expresión génica similares a los observados en plantas senescentes llevamos a cabo un estudio comparativo entre el transcriptoma de plantas infectadas y el de plantas que mostraban senescencia asociada al desarrollo o senescencia inducida por oscuridad (Lin and Wu, 2004; Buchanan-Wollaston et al., 2005; Fernandez-Calvino et al., 2014). En este análisis se identificaron 68 genes que respondieron de manera similar a la infección por virus y a los dos procesos de senescencia (Fernandez-Calvino et al., 2016). Curiosamente, el $61 \%$ de los genes sensibles a TRV se alteraron en la misma dirección (inducción o represión) que lo observado en situaciones de senescencia natural o inducida artificialmente. En ambos casos, el número de genes comunes a estos tres procesos fue significativamente mayor que el esperado en una distribución aleatoria ( $\mathrm{P}<0,0001$ ), lo que sugiere importantes concomitancias en sus respuestas transcripcionales. La iniciación y progresión de la senescencia de la planta parece por tanto implicar vías de señalización interconectadas que regulan respuestas asociadas a la infección. Determinar cuales son sus elementos comunes y su relevancia funcional es clave para entender la contribución de los genes de senescencia al proceso infectivo.

En este estudio, identificamos un conjunto de genes denominados colectivamente como Dark-inducible (DIN) que respondieron activamente a la infección por TRV. Los genes DIN se inducen no solo en hojas senescentes (Quirino et al., 2000; Fujiki et al., 
2001; Lin and Wu, 2004; Fujiki et al., 2005) sino también en respuesta a otros estímulos. Este hallazgo sugiere que los genes DIN podrían participar en eventos celulares que son comunes a la senescencia y la invasión por patógenos (Zimmermann et al., 2004). Sin embargo, aunque algunos genes DIN, como DIN1, DIN6 o DIN11, se han utilizado tradicionalmente como marcadores para caracterizar las respuestas asociadas a la senescencia, su regulación y función durante las interacciones compatibles entre virus y plantas hospedadoras es en gran parte desconocida (Lam et al., 1994; Schenk et al., 2005). 


\subsection{Objetivos}

Los virus de plantas son uno de los grupos de organismos parásitos que provocan los daños más graves en las plantas cultivadas (Strange and Scott, 2005). Las interacciones entre las plantas y los virus son complejas y diversas y van desde la reacción incompatible en la que el virus es incapaz de replicarse en la planta inoculada hasta la susceptibilidad total o tolerancia en la que la infección transcurre en ausencia de enfermedad (Maule et al., 2002). Entre medias, se han descrito distintos tipos de resistencia verdadera más o menos efectiva que incluyen la resistencia no huésped y la resistencia específica de cultivar (Ritzenthaler, 2005). La dificultad para controlar las virosis en los cultivos hace que gran parte de los esfuerzos vayan destinados a la búsqueda de cultivares resistentes (Moffett, 2009). Sin embargo, las interacciones entre la planta y el virus son tan dinámicas que la presión selectiva de la resistencia, ya sea dominante o recesiva, favorece con frecuencia la emergencia de poblaciones virales adaptadas (Truniger and Aranda, 2009; Elena et al., 2014). Por ello, la protección sostenible de los cultivos frente a un amplio rango de potenciales patógenos virales solo puede conseguirse a través de un conocimiento completo de los mecanismos moleculares que determinan las relaciones de compatibilidad y resistencia planta-virus y las causas de la enfermedad.

Con esta premisa hemos estructurado la presente tesis en torno a dos grandes objetivos. 1) Explorar las relaciones entre el silenciamiento génico y la respuesta inmune en el curso de una infección a través del estudio de la regulación de $B I R l$ y de su función en la defensa antiviral. 2) Analizar la interacción entre senescencia e infección a través del estudio de la expresión de los genes $D I N$ y de su papel como elementos moduladores de susceptibilidad y/o resistencia. Para lograr este propósito nos planteamos abordar los siguientes objetivos específicos:

1) Estudiar el efecto de la infección sobre la expresión de componentes de la vía de señalización dependiente de BIR1 y su relevancia biológica.

2) Determinar las bases moleculares de la inducción de BIR1 por virus.

3) Determinar el mecanismo de regulación transcripcional de BIRl.

4) Determinar el mecanismo de regulación post-transcripcional de $B I R 1$.

5) Estudiar la relevancia biológica de la regulación de BIRl durante la infección.

6) Analizar el patrón de expresión de genes DIN en plantas infectadas con virus. 
7) Determinar el papel que desempeña DIN11 en la modulación de la susceptibilidad a la infección por virus. 

2. MATERIALES Y MÉTODOS 



\section{MATERIALES Y MÉTODOS}

\subsection{Material vegetal y viral}

\subsubsection{Material vegetal y condiciones de crecimiento}

Las plantas de Arabidopsis se cultivaron en cámaras de cultivo a $19-22^{\circ} \mathrm{C}$ con fotoperiodo de 16:8 horas de luz:oscuridad y humedad relativa de 60-75\%. Las plantas de $N$. benthamiana se cultivaron en cámaras a $22-24^{\circ} \mathrm{C}$ con fotoperiodo de $16: 8$ horas de luz:oscuridad y humedad relativa de $60-75 \%$. Para el cultivo en tierra, sembramos las semillas en macetas o alveolos de plástico que contenían una mezcla de sustrato orgánico (turba negra) y vermiculita en una proporción 3:1. Tras la siembra las macetas/alveolos se colocaron en bandejas cubiertas con plástico transparente para mantener la humedad adecuada durante la germinación de las semillas. Las semillas se mantuvieron estratificando a $4^{\circ} \mathrm{C}$ en oscuridad durante al menos 24 horas antes de su traslado a la cámara de cultivo.

Para el cultivo in vitro las semillas de Arabidopsis se esterilizaron con vapores de cloro gas con 5\% de $\mathrm{ClH}$ en hipoclorito de sodio durante $3 \mathrm{~h}$. Las semillas se sembraron en placas Petri con medio Murashige y Skoog 0,5X (MS a 2,35 g/L, MES a 0,5 g/L pH 5,7 ) suplementado con $1 \%$ de sacarosa y solidificado con $0,9 \%$ de Plantagar. Las placas se sellaron con cinta $3 \mathrm{M}$ Micropore. En todos los casos las semillas estratificaron durante 48 horas a $4^{\circ} \mathrm{C}$ en oscuridad.

Los mutantes ago1-27, y los mutantes simples o múltiples $r d r 1-1, r d r 2-1, r d r 6-15$, $d c l 2-1$, dcl3-1 y dcl4-2 fueron donados por James C. Carrington (The Donald Danforth Plant Center, MO, USA). Las líneas mutantes cmt3-11t y $d d c$ fueron suministradas por Steve Jacobsen (UCLA-HHMI, USA). Las Arabidopsis mutantes nrpe1 (nrpd1b-11) fueron donadas por Craig Pikaard (Indiana Unversity, USA). Las semillas del mutante drm2-2 nos las proporcionó Eric Richards (Boyce Thompson Institute, Cornell University, NY, USA). Los mutantes nprl-1 fueron suministrados por Xinnian Dong (Duke University, NC, USA). Las líneas mutantes bir1-1, sobir1-12, sobirl-1 birl-1 y bir1-1/BIR1-HA fueron donadas por Yuelin Zhang (University of British Columbia, Canada). Las semillas del mutante sid2-2 nos las suministró Francisco Tenllado (Centro de Investigaciones Biológicas, CSIC, España)

Los mutantes de inserción de T-DNA para el locus At4g39838 que contiene el hipotético miR5658 (líneas SALK_093172C y SALK_091507C) y para la líneas homocigotas din1 (código NASC N665464, SALK_020571C) y din6 (código NASC N479505, GK-829B05) se obtuvieron a través del Salk Institute Genomic Analysis Laboratory. $\operatorname{din} 1$ contiene una inserción de T-DNA en el primer intrón del locus 
At4g35770 (coordenada 16.945.146). din6 contiene una inserción de T-DNA en el primer exón del gen At3g47340 (coordenada 17,441,009), 35 nucleótidos en sentido descendente desde el sitio de inicio de la traducción.

Todos los mutantes de inserción empleados se han generado sobre el fondo genético Col-0 y se genotiparon en nuestro laboratorio antes de realizar cualquier experimento. Los cebadores utilizados para en el genotipado por PCR de mutantes homocigotos se enumeran en el Apéndice.

\subsubsection{Construcción de plantas transgénicas}

Para la construcción de las Arabidopsis transgénicas que expresan la proteína de fusión GFP:GUS bajo el control del promotor de BIRl se amplificó por PCR un fragmento de $3.297 \mathrm{pb}$ que contenía el promotor de BIR1 a partir de una preparación de DNA genómico de plantas Col-0 y se clonó en el vector Gateway pDONR207. A continuación se introdujo aguas arriba de la proteína de fusión GFP:GUS en el vector pBGWFS7 empleando la tecnología Gateway

Para la construcción de las Arabidopsis transgénicas sobreexpresoras de BIR1 y sus derivados se empleó un sistema de expresión génica inducible por dexametasona (DEX) (Marques-Bueno et al., 2016). La construcción GVG:: ter::6xUAS/pDONR221 que contiene el casete GVG (compuesto por un dominio de unión GAL4 DNA, una secuencia activadora VP16 del virus del herpes y un receptor de glucocorticoide GR de rata) fue clonado en el vector pDONR221. A continuación se añadió un marcador mCherry para generar la construcción GVG::ter::6xUAS::mCherry/ pDONR221. De forma paralela se generó el vector pDONR221-BIR1 que contenía la región 5'UTR de BIR1 y su región codificadora en la versión silvestre y mutantes. Los vectores finales se obtuvieron empleando un sistema de recombinación de tres fragmentos y el vector destino $\mathrm{pH} 7 \mathrm{~m} 34 \mathrm{GW}$.

El vector RNAi Gateway ${ }^{\circledR}$ pH7GWIWG2 (II) (Invitrogen) se usó para generar una construcción RNAi dirigida contra AtDIN11 bajo el promotor constitutivo 35S. La región diana seleccionada comprendía un fragmento de $431 \mathrm{pb}$ del extremo 5' terminal del RNA mensajero del gen de Arabidopsis AtDIN11.

Las construcciones finales se emplearon para transformar Agrobacterium tumefaciens GV3101 electrocompetentes por electroporación aplicando un voltaje de $2,2 \mathrm{Kv}$ a una resistencia de $200 \Omega$ y a una capacitancia de $25 \mu \mathrm{f}$. Las plantas de Arabidopsis del ecotipo Col-0 se transformaron sumergiendo las partes aéreas y flores ("floral dip method") (Clough and Bent, 1998) en condiciones de vacío en una solución de Agrobacterium con la construcción de interés con un 5\% de sacarosa y $500 \mu 1 / \mathrm{L}$ de 
Silwet L-77. La presencia del transgen se confirmó mediante PCR en plantas de la T1. Finalmente mediante un estudio de segregación en presencia del agente de selección se seleccionaron varias líneas homocigotas independientes con una única inserción del transgen. Para todos los experimentos se empleó la generación T4.

\subsubsection{Aislados virales}

Los clones infecciosos derivados del virus del cascabeleo del tabaco (TRV, del inglés Tobacco rattle virus) se realizaron a partir de un clon de TRV ya descrito (Liu et al., 2002). Este clon está compuesto por dos vectores virales que portan las secuencias genómicas de los RNAs 1 y 2 de TRV. El plásmido que porta el RNA1 (pTRV1) contiene una copia completa de su cDNA. El plásmido recombinante TRV-GFP contiene la proteína verde fluorescente soluble modificada (GFP) integrada en el RNA2. LA GFP está fusionada a tres epítopos HA en su extremo carboxilo terminal y su expresión está controlada por el promotor de la replicasa del virus del bronceado temprano del guisante (PEBV, del inglés Pea early browning virus) (Fernandez-Calvino et al., 2016a).

En el sistema TRV-BIR1 el RNA2 de TRV contiene un fragmento de cDNA con la secuencia 5'UTR y la región codificadora de BIR1 de Arabidopsis. El cDNA se amplificó por RT-PCR a partir de RNA total de plantas Col-0 y se clonó en el vector Gateway pDONR207. A continuación se introdujo en el vector pGWB14 empleando la tecnología Gateway. Mediante PCR se amplificó la secuencia de BIR1 fusionada a tres epítopos HA desde el clon intermediario pDONR207-BIR1 y se clonó en el sitio de clonaje múltiple del pTRV2 adyacente al promotor de PEBV, en los sitios de restricción $S t u I-K p n I$. Los clones recombinantes se validaron mediante digestión con enzimas de restricción y secuenciación.

Los vectores TRV1 y pTRV2:00 fueron cedidos al laboratorio por el Dr. S.P. Dinesh-Kumar (University of California, CA, USA). Salvo otras indicaciones, emplearemos el nombre TRV para referirnos al sistema combinado de TRV1 y TRV2: GFP-HA.

El clon infeccioso de TuMV deriva de la cepa UK1 y está compuesto por un vector viral que porta una copia de cDNA de la secuencia genómica del RNA del virus unida a la secuencia de la proteína GFP (Lellis et al., 2002). Este plásmido pTuMV-GFP fue cedido por James C. Carrington (Donald Danforth Plant Science Center, MI, USA). El vector binario pGR107 contiene una copia cDNA del genoma del virus X de la patata (PVX, del inglés Potato virus $X$ ) y fue cedido por David Baulcombe (University of Cambridge, Reino Unido). 
Para generar los derivados pTRV2 y pGR107 utilizados en ensayos de silenciamiento inducido por virus (VIGS, del inglés virus-induced gene silencing), fragmentos de cDNA de aproximadamente 300 bp de los genes NbNRIP1 (EU332891.1), AtDIN6/ASN1 (At3g47340) y NbDIN11 se amplificaron por RT-PCR a partir de preparaciones de RNA y se clonaron en vectores pCR2.1 (Invitrogen) para su secuenciación. El fragmento de NbNRIP1 corresponde a los nucleótidos 58-360. El fragmento de AtDIN6/ASN1 en las posiciones nucleotídicas 25-330 comparte una similitud de secuencia del $77 \%$ a nivel de nucleótidos con su homólogo NbASN (GQ354808 / C9DFA8). El fragmento correspondiente a los nucleótidos 462-784 es homólogo en Arabidopsis del gen DIN11 de S. tuberosum (clon 069B08).

\subsection{Expresión transitoria, inoculación viral y tratamientos vegetales}

\subsubsection{Expresión transitoria en $N$. benthamiana}

Para los ensayos de expresión transitoria en $N$. benthamiana se emplearon las cepas de Agrobacterium tumefaciens GV2260 y GV3101. Las bacterias se incubaron en 50 $\mathrm{mL}$ de medio Luria-Bertani (LB) (bacto-triptona a $10 \mathrm{~g} / \mathrm{L}$, extracto de levadura a $5 \mathrm{~g} / \mathrm{L}$ y $\mathrm{ClNa}$ a $10 \mathrm{~g} / \mathrm{L}$ ) durante 48 horas a $28^{\circ} \mathrm{C}$ en oscuridad y con una agitación de $200 \mathrm{rpm}$ empleando rifampicina $(50 \mu \mathrm{g} / \mathrm{mL})$, kanamicina $(50 \mu \mathrm{g} / \mathrm{mL})$, tetraciclina $(12,5 \mu \mathrm{g} / \mathrm{mL})$, streptomicina $(50 \mu \mathrm{g} / \mathrm{mL})$ o gentamicina $(25 \mu \mathrm{g} / \mathrm{mL})$ como antibióticos de selección. Los cultivos se centrifugaron a $4.800 \mathrm{rpm}$ durante 15 minutos y se resuspendieron en solución de infiltración (MES a $10 \mathrm{mM} \mathrm{pH} \mathrm{5,6,} \mathrm{MgCl}_{2}$ a $10 \mathrm{mM}$ y acetosiringona a 0,15 $\mathrm{mM}$ ). Los cultivos se incubaron de 4 a 5 horas a temperatura ambiente en oscuridad y se infiltraron sobre el envés de las hojas a una densidad óptica (DO) a $600 \mathrm{~nm}$ final de 0,8.

\subsubsection{Inoculación de virus}

Para la inoculación de los clones virales infecciosos en $N$. benthamiana se empleó el sistema de agroinfiltración descrito en el apartado 3.2.1. La infiltración se hizo en el envés de las hojas de plantas de aproximadamente 21 días empleando una jeringa sin aguja. Los cultivos que contienen los plásmidos pTRV1 y pTRV2 se inocularon en una proporción 1:1 a una $\mathrm{DO}_{600}$ de 0,8 .

Las hojas de la roseta de Arabidopsis se inocularon a las tres semanas de su germinación empleando extracto vegetal de plantas de $N$. benthamiana infectadas sistémicamente. El extracto se preparó a partir de hojas superiores no agroinfiltradas a los 4 días de la inoculación con TRV o TuMV. Para ello se homogeneizó en mortero $1 \mathrm{~g}$ de tejido vegetal en $1 \mathrm{~mL}$ de tampón fosfato sódico a $0,1 \mathrm{M} \mathrm{pH} \mathrm{7,2} \mathrm{y} \mathrm{carborundo} \mathrm{como}$ agente abrasivo. La inoculación se realizó manualmente, extendiendo el extracto con 
una ligera presión sobre las hojas de la roseta de Arabidopsis. El extracto sobrante de las hojas inoculadas se aclaró con agua destilada.

La inoculación viral de Arabidopsis cultivadas en placa se realizó una semana después de su germinación. Los cultivos bacterianos se ajustaron a una $\mathrm{DO}_{600}$ final de 1,5 y se aplicaron en condiciones de esterilidad sobre las hojas de la planta mediante una leve punción con un palillo de madera impregnado en la solución de Agrobacterium.

\subsubsection{Aplicación de DEX en plantas de Arabidopsis}

Para los tratamientos con DEX se empleó una solución de DEX (Cayman Chemical Company) a $30 \mathrm{mM}$ en etanol del 100\%. Las plantas de Arabidopsis de tres semanas se pulverizaron con $1 \mathrm{~mL}$ de la solución de DEX desde $15 \mathrm{~cm}$ de distancia a intervalos de 24 horas durante 6 días consecutivos.

\subsubsection{Aplicación de SA y determinación de los niveles de SA}

Para el tratamiento con SA se empleó un solución concentrada de SA (SIGMA) a 1 $\mathrm{M}$ en etanol del 100\%. Las plantas de Arabidopsis de tres semanas se pulverizaron con $1 \mathrm{~mL}$ de una solución de SA a $1 \mathrm{mM}$ desde $15 \mathrm{~cm}$ de distancia. Las muestras de hoja de roseta se recogieron a 6,12 y 24 horas tras el tratamiento y se congelaron en nitrógeno líquido para su posterior análisis molecular.

Para comprobar el efecto del SA sobre la acumulación de TRV las plantas fueron inoculadas con TRV o con extracto de plantas sanas como control 24 horas después de la primera aplicación de SA. Después las plantas se pulverizaron con la solución de SA o control durante 8 días consecutivos a intervalos de 24 horas (Exp\#1) o 48 horas $(\operatorname{Exp} \# 2)$.

La medición de los niveles de SA se realizó en muestras de cinco réplicas biológicas independientes recogidas a 8,10 y 14 días post-inoculación. Cada muestra consistía en 4 hojas de roseta de cinco plantas diferentes. Las hojas muestreadas ocupaban una posición equivalente en la roseta con el fin de minimizar las posibles variaciones en el contenido hormonal dentro de cada planta. Se muestrearon plantas no inoculadas (sanas), inoculadas con extracto de planta sana o infectadas con TRV. Las muestras se analizaron mediante espectrometría de masas acoplada a cromatografía de gases (GC-TOF-MS, del inglés Gas Chromatography-Time-of-Flight Mass Spectrometry) (Pegasus III, Leco), y se cuantificó respecto a un estándar interno $\left(\left[{ }^{2} \mathrm{H}_{4}\right]\right.$ SA; OlChemIm Ltd, Olomouc, Czech Republic) como se describe en (Vallarino and Osorio, 2016). 


\subsubsection{Preparación de protoplastos y transfección}

Los protoplastos de Arabidopsis se aislaron de hojas de roseta de plantas de tres semanas de edad y se transformaron mediante el método del polietilenglicol (Yoo et al., 2007) utilizando $30 \mu \mathrm{g}$ de plásmido pTRV1 purificado. Los protoplastos transfectados se incubaron durante $24 \mathrm{~h}$ en una cámara de crecimiento a $16 \mathrm{~h}$ de luz a $20^{\circ} \mathrm{C} \mathrm{y} 8 \mathrm{~h}$ de oscuridad a $22^{\circ} \mathrm{C}$. Los protoplastos se recogieron mediante centrifugación, se suspendieron en $500 \mu \mathrm{l}$ de reactivo Trizol para extracción de RNA total y se almacenaron a $-80^{\circ} \mathrm{C}$ hasta su uso.

\subsection{Purificación y análisis de DNA}

\subsubsection{Purificación de DNA genómico}

La extracción de DNA genómico se llevó a cabo en tampón de extracción (2\% de CTAB, Tris-Cl a $100 \mathrm{mM}$ pH 8,0, EDTA a $20 \mathrm{mM}$ pH 8,0, $\mathrm{NaCl}$ a 1,4 M, 1\% de PVP 40.000 ) a partir de tejido vegetal fresco homogenizado en nitrógeno líquido. El extracto se clarificó con cloroformo:isoamilalcohol 24:1, se centrifugó a 10.000 rpm y se precipitó con isopropanol.

\subsubsection{Purificación de DNA plasmídico}

El DNA plasmídico se extrajo con el kit comercial Qiagen Plasmid Midi Kit (Qiagen) siguiendo las instrucciones del fabricante. La cuantifiación del DNA se realizó utilizando un espectrofotómetro NanoDrop 200 (Thermo Scientific) a una longitud de onda de $260 \mathrm{~nm}$.

\subsubsection{Transcripción Inversa}

Para la síntesis de cadenas complementarias de DNA (cDNA) se utilizó la reacción de transcripción inversa (RT) empleando la enzima Superscript III Reverse Transcriptase $200 \mathrm{U} / \mu 1$ (Invitrogen) siguiendo las instrucciones del fabricante.

\subsubsection{Amplificación de DNA mediante PCR}

La reacción en cadena de la polimerasa (PCR, del inglés polymerase chain reaction) se llevó a cabo empleando el kit comercial NZYTaqII DNA Polymerase (NZY technologies) siguiendo las indicaciones del fabricante y en presencia de cebadores específicos a concentración final de $0,3 \mu \mathrm{M}$. Las condiciones del programa de 
amplificación variaron según la pareja de cebadores empleada y el tamaño del fragmento que se deseaba amplificar. Las reacciones se llevaron a cabo en termicocladores PTC-100TM (MJ Research, INC).

\subsubsection{Electroforesis en gel de agarosa.}

La electroforesis en gel de agarosa (Pronadisa, Conda) se utilizó para la separación de fragmentos de ácido nucleicos. Se emplearon geles al 1 o 2\% según el tamaño de los fragmentos de interés. Como electrolito se empleó Tris-Borato EDTA (TBE) 0,5X pH 8,0. Se usó el marcador de peso molecular GeneRuler $1 \mathrm{~Kb}$ DNA ladder plus (Fermentas). La electroforesis se llevó a cabo entre 80 y 120V. El gel se tiñó con bromuro de etidio (BrEt) y se visualizó en luz ultravioleta (UV) mediante un transiluminador.

\subsubsection{Purificación de fragmentos de PCR}

La elución de productos de DNA tras su separación en geles de agarosa se llevó a cabo mediante el kit comercial "GENECLEAN Turbo" (MP Biomedicals) siguiendo las instrucciones del fabricante.

\subsubsection{Marcaje radioactivo de sondas}

Para la detección de las secuencias nucleotídicas en los ensayos de Northern blot se emplearon sondas de cDNA marcadas radiactivamente. Las sondas se prepararon a partir de productos de PCR purificados con el kit "GENECLEAN Turbo" (MP Biomedicals). La técnica de marcaje fue el "randon priming" en presencia de $[\alpha-32 \mathrm{P}]-$ dCTP (6.000 Ci/mmol; $10 \mathrm{mCi} / \mathrm{mL})$ usando el fragmento "Klenow" de la DNA polimerasa I (NEBL) según las instrucciones del fabricante. Los nucleótidos no incorporados a la reacción se eliminaron usando el sistema "P30 Micro Bio-Spin Chromatography columns" (BioRad). La sonda radiactiva se desnaturalizó a $90^{\circ} \mathrm{C}$ durante 5 minutos, se enfrió en hielo durante más de 2 minutos y se añadió a la solución de hibridación. La radioactividad final incorporada a la reacción se midió usando un contador de centelleo "1.450 MicroBeta triluk" (Perkin Elmer) y varió entre 1 a 2 millones de cuentas por minuto (cpm) por $\mathrm{mL}$ de tampón de hibridación.

\subsubsection{Análisis de metilación.}

Los análisis de Chop-PCR se llevaron a cabo como se describen en (Bohmdorfer et al., 2014). Para ello, el DNA genómico (100 ng) de hojas de roseta de Arabidopsis de 
tres semanas de edad se digirió con las enzimas de restricción sensibles a la metilación DdeI y NlaIII. A continuación el DNA digerido y sin digerir (control) se usó como molde para una amplificación específica de gen mediante PCR convencional y posterior separación de los fragmentos de amplificación en gel de agarosa. La Chop-qPCR se realizó con la polimerasa Maxima Hot Start Taq DNA Polymerase (Thermo Scientific) y 25x SYBR Green (Invitrogen) diluído a 1:400.

La secuenciación por bisulfito específica de gen se realizó como en (He et al., 2009). El DNA de hojas de roseta de Arabidopsis de tres semanas se extrajo con el kit comercial DNeasy Plant Mini Kit (QIAGEN). La reacción de conversión por bisulfito se realizó con el kit comercial EZ DNA Methylation Startup kit (Zymo Research). La PCR se realizó con la polimerasa Maxima Hot Start Taq DNA Polymerase (Thermo Scientific) y los productos de amplificación se clonaron en el plásmido TOPO TA (Invitrogen). Con ese plásmido se transformaron bacterias E. coli electrocompetentes por electroporación y se secuenciaron un mínimo de 30 clones transformantes. Una región no metilada entre las posiciones 19.573 .407 y 19.573 .671 del cromosoma 4 se usó como control de la conversión por bisulfito. Los cebadores empleados se diseñaron con el programa Primer 3 siguiendo las directrices de (Patterson et al., 2011).

\subsubsection{Identificación de puntos de unión de TF.}

Para escanear la secuencia promotora de BIR1 (1.500 pb aguas arriba del punto de inicio de la transcripción) se emplearon matrices de posición de peso (PWMs) obtenidas de (Franco-Zorrilla et al., 2014) y Cis-BP (http://cisbp.ccbr.utoronto.ca/; (Weirauch et al., 2014)). El escaneado se llevó a cabo con la herramienta 'matrix-scan' en Regulatory Sequence Analysis Tools (RSAT) (Medina-Rivera et al., 2015), con un p-valor umbral $<1,0 \mathrm{E}-4$ y un fondo estimado de un modelo de Markov de orden 2.

\subsection{Purificación y análisis de RNA}

\subsubsection{Purificación de RNA total}

El RNA total se extrajo del tejido vegetal mediante el reactivo TRIzol (Life technologies), siguiendo las instrucciones del fabricante y utilizando tejido vegetal fresco homogeneizado en nitrógeno líquido. La cuantificación del RNA se realizó utilizando un espectrofotómetro NanoDrop 200 (Thermo Scientific) a una longitud de onda de $260 \mathrm{~nm}$. 


\subsubsection{Northern blot}

Las muestras de RNA (aproximadamente $5 \mu \mathrm{g}$ ) se desnaturalizaron a $65^{\circ} \mathrm{C}$ durante 4 minutos en presencia de tampón de carga $5 \times(0,03 \%$ de azul de bromofenol, EDTA a $5 \mathrm{mM}, 7,4 \%$ de formaldehido, $20 \%$ de glicerol, 30\% de formamida, tampón 3morfolino-propano-sulfónico (MOPS) a $80 \mathrm{mM}$, acetato sódico a $20 \mathrm{mM}$ y bromuro de etidio a $0,2 \mu \mathrm{g} / \mu \mathrm{l})$. Las muestras se separaron en geles desnaturalizantes de agarosa al 1,5\% que contenían HEPES a $20 \mathrm{mM}$ pH 7,8, EDTA a $1 \mathrm{mM}$ pH 8,0 y 5\% de formaldehido. Los geles se corrieron en tampón HEPES a $20 \mathrm{mM}$ pH 7,8 y EDTA a 1 $\mathrm{mM}$ pH 8,0 a 70-80 V durante el tiempo necesario para la correcta separación de los fragmentos. Al finalizar la electroforesis confirmamos la normalización de la carga de RNA visualizando los RNAs ribosomales en el gel teñido con bromuro de etidio bajo luz UV. Los geles se sometieron a un proceso de hidrólisis incubando en una solución $0,01 \mathrm{M}$ de $\mathrm{NaOH}$ y $3 \mathrm{M}$ de $\mathrm{NaCl}$ durante 20 minutos. El RNA se transfirió a membranas de nylon cargadas positivamente (GE Healthcare) por capilaridad en tampón SSC 10x durante $15 \mathrm{~h}$.

Para la detección de los pequeños RNAS en ensayos Northern Blot se emplearon muestras enriquecidas en RNA de bajo peso molecular (aproximadamente $30 \mu \mathrm{g}$ ). Las muestras se desnaturalizaron a $65^{\circ} \mathrm{C}$ en un volumen de formamida durante 5 minutos y se separaron en geles desnaturalizantes de poliacrilamida al $15 \%$ (acrilamida/bisacrilamida, 37,5:1) y urea al 7\%. La electroforesis se realizó en tampón TBE $0,5 \mathrm{X}$ a $90 \mathrm{~V}$. Los geles se tiñieron con bromuro de etidio y se visualizaron bajo luz UV para confirmar la normalización de la carga de RNA. El RNA se transfirió a una membrana de nylon cargada positivamente (GE-Healthcare) mediante electrotransferencia semiseca a $190 \mathrm{~mA}$ durante 40 minutos empleando tampón TBE $0,5 \mathrm{X}$ y el aparato Trans-blot semi dry transfer cell (BioRad).

Tras la transferencia, en todos los casos, las membranas se expusieron a radiación UV de 1200 julios para fijar el RNA con un Stratalinker modelo 1.800 (Stratagene). Las membranas se incubaron a $42^{\circ} \mathrm{C}$ en tampón comercial "Perfect-Hyb" (Sigma) durante al menos $1 \mathrm{~h}$. A continuación, se añadió la sonda correspondiente ya desnaturalizada sobre la solución de hibridación y las membranas se incubaron durante 16 horas a $42^{\circ} \mathrm{C}$. Tras la hibridación la membrana se lavó sucesivamente en soluciones de SSC y SDS de concentración decreciente según el siguiente esquema: 2 lavados con SSC 2X y SDS al 0,2\%, 1 lavado con SSC $1 \mathrm{X}$ y SDS al 0,1\% y 1 último lavado con SSC 0,1X y SDS al $0,1 \%$ a $50-65^{\circ} \mathrm{C}$ dependiendo del tipo de sonda empleado. 
Por último, se expusieron películas sensibles a rayos X BioMax XAR film (Kodak) sobre las membranas hibridadas con la sonda marcada durante el tiempo necesario y se revelaron con un revelador "RX AGFA Curix60".

\subsubsection{RT-PCR cuantitativa}

Las preparaciones purificadas de RNA se trataron con DNasa I (Invitrogen) durante 30 minutos a $37^{\circ} \mathrm{C}$ para eliminar restos de DNA genómico. Las muestras se ajustaron a una concentración final de $10 \mathrm{ng} / \mu \mathrm{l}$. Tanto la reacción $\mathrm{RT}$ como la amplificación con PCR se llevaron a cabo en un mismo paso empleando Brilliant III Ultra-Fast SYBR Green QRT-PCR Master Mix (Agilent Technologies) en el aparato Rotor-Gene 6.000/Rotor-Gene Q real-time PCR machine (Corbett/Qiagen). Las mezcla de reacción se llevó a un volumen final de $15 \mu 1$ con $3 \mu 1$ de RNA $(10 \mathrm{ng} / \mu \mathrm{l}), 0,5 \mu \mathrm{M}$ de cada cebador específico y $12 \mu \mathrm{l}$ de la mezcla de reacción Brilliant III Ultra-Fast SYBR ${ }^{\circledR}$ Green (Agilent Technologies) siguiendo las instrucciones del fabricante. Por cada muestra se analizaron 3 réplicas técnicas dentro de cada carrera y dos carreras de PCR distintas. Los fragmentos amplificados tenían un tamaño aproximado de $150 \mathrm{nts}$ y los cebadores se diseñaron de acuerdo al programa Primer 3. Las condiciones de amplificación fueron: $50^{\circ} \mathrm{C}$ durante 10 minutos (transcripción inversa), incubación a $95^{\circ} \mathrm{C}$ durante 3 minutos (activación) y 40 ciclos de $95^{\circ} \mathrm{C}$ durante 10 segundos (desnaturalización), $60^{\circ} \mathrm{C}$ durante 20 segundos (anillamiento de los cebadores) y $72^{\circ} \mathrm{C}$ durante 20 segundos (elongación). El último paso consiste en una rampa de 60 a $95^{\circ} \mathrm{C}$ aumentando la temperatura $1^{\circ} \mathrm{C}$ cada 5 segundos (curva de fusión).

La cuantificación relativa de transcritos de genes de Arabidopsis se realizó usando el método "Delta-delta cycle threshold" (Livak and Schmittgen, 2001) con el programa Rotor-Gene 6.000 Series software Los genes endógenos Actina2 y CBP20 se emplearon como normalizadores ya que su expresión no se ve alterada en ninguno de los fondos genéticos analizados ó en los distintos tratamientos aplicados. La concentración absoluta de transcritos virales se realizó a partir de una curva estándar de transcritos in vitro de concentración conocida y se expresó como el número de copias virales por nanogramo (ng) de RNA total. Las barras de error en los gráficos de expresión representan la desviación estándar de tres medidas técnicas.

\subsubsection{5' RACE (rapid amplification of cDNA ends)}

Los ensayos de 5' RACE se realizaron según (Donaire et al., 2011). Para ello se emplearon preparaciones purificadas de mRNA poli (A) (250 ng) obtenidas con el kit comercial "Oligotex mRNA Mini Kit" (Qiagen) a partir de RNA total de Arabidopsis. El RNA poliadenilado se ligó con un adaptador de RNA (A1; $50 \mathrm{ng}$ ) añadiendo $20 \mathrm{U}$ de T4 RNA ligase (NEBL) a $4^{\circ} \mathrm{C}$ durante $16 \mathrm{~h}$. Este adaptador posee un extremo 3'-OH de 
modo que forma enlace fosfodiéster con el extremo 5'-P de los mRNAs procesados por sRNAs (Llave et al., 2002b). El RNA híbrido formado se purificó con fenol:cloroformo y se precipitó con etanol. El producto purificado se empleó como molde para una transcripción inversa con "Superscript II" (Invitrogen). Como cebador en la RT se usó un oligod(T) comercial, "Gene Race oligodT" (Roche), cuya secuencia es complementaria a la secuencia de la cola poli (A). Sobre este cDNA monocatenario se realizó una PCR base con la enzima “AmpliTaq DNA polimerase” (Roche), utilizando como cebador directo un oligonucleótido cuya secuencia corresponde parcialmente con el adaptador A1. Como cebador reverso se empleó un oligonucleótido complementario de la secuencia fusionada en posición 5' con el oligo empleado en la RT. El producto de amplificación de la PCR base se empleó como molde para la amplificación de productos específicos con ayuda de la "Hot Start Ampli-Taq GOLD polymerase” (Roche).

\subsubsection{Genotecas de sRNAs y de degradoma.}

Las genotecas para el análisis de degradoma se prepararon a partir de muestras de hoja o de muestras de inflorescencia de Arabidopsis y se analizaron mediante hibridación con micromatrices o por ultrasecuenciación. Las muestras de hoja contenían hojas de roseta (superiores no inoculadas) de 10-12 plantas recolectadas a los 8 dpi (TRV) o 14 dpi (TuMV), mientras que las muestras de inflorescencia contenían inflorescencias obtenidas de 10-15 plantas a los 16 dpi. Previamente, se comprobó que todas las muestras estaban infectadas con el virus correspondiente y que los controles negativos inoculados con tampón estaban libres de infección. El tejido muestreado se congeló inmediatamente en nitrógeno líquido y se guardó a $-80^{\circ} \mathrm{C}$ hasta su análisis.

El RNA total de las muestras se extrajo con TRIzol reagent (Invitrogen) o el kit comercial Plant RNeasy Kit (QIAGEN) y su calidad fue corroborada mediante el sistema Agilent 2.100 bioanalyzer. La construcción de las librerías del degradoma se abordó mediante dos aproximaciones experimentales complementarias empleando preparaciones purificadas de mRNA poli (A) obtenidas con el kit comercial "Oligotex mRNA Mini Kit" (Qiagen) a partir de RNA total de Arabidopsis. 1) Se prepararon genotecas de "procesoma" para la identificación de genes procesados diferencialmente mediante ligación de transcritos cortados en 5' a adaptadores terminales, amplificación mediada por la RNA polimerasa T7 e hibridación con micromatrices tal y como se describe en (Franco-Zorrilla et al., 2009). Tres réplicas biológicas independientes con sus correspondientes controles negativos se hibridaron independientemente con microarrays ATH1 (Affymetrix) que contenían sondas para 24.000 variantes de transcritos de 22.500 genes de Arabidopsis. Para reducir los falsos positivos en las hibridaciones se comparó el cDNA enriquecido con los controles negativos. Estos 
consistían en poblaciones de cDNA en las cuales se incluía el adaptador de RNA sin ligar a transcritos cortados en $5^{\prime}$. Aquellos transcritos que mostraron un incremento $\geq 2$ $\mathrm{y}$ una tasa de falsa aparición $\leq 0,05$ se consideraron significativamente sobrerrepresentados en la población en relación con los controles negativos. 2) Se prepararon librerías de degradoma (PARE, del ingles Parallel Analysis of RNA End) como se describe en (German et al., 2009) para su análisis por secuenciación [Fasteris (www.fasterix.com), IGA Technology (www.igatechnology.com)] empleando un secuenciador Illumina (HiSeq2.000, 1x50 pb, single-end run). Los resultados de la secuenciación se analizaron mediante la herramienta CleaveLand4 (Addo-Quaye et al., 2009). En resumen, todas las secuencias del degradoma con coincidencias exactas en RNA estructural se retiraron y los datos filtrados se mapearon frente a la secuencia del transcriptoma de cDNA de Arabidopsis (TAIR10) usando Bowtie. Para cada coincidencia se extrajo la secuencia incluyendo $13 \mathrm{nts}$ aguas arriba y aguas abajo del punto de corte detectado en el degradoma para crear una secuencia de mRNA de búsqueda de 26 nts de longitud. Se realizó un alineamiento entre cada secuencia de búsqueda y cada sRNA en nuestra base de datos o en la base de datos de miRNAs de la miRBase mediante la herramienta GSTAr. Todas las coincidencias se ordenaron en categorías según la abundancia de cada punto de corte relativa al perfil total de las marcas del degradoma que combinaban con las dianas (Addo-Quaye et al., 2009).

Las genotecas para el análisis de sRNAs se prepararon empleando el mismo esquema de muestreo y se analizaron por ultrasecuenciación en un secuenciador Illumina Genome Analyzer (HiSeq2.000, 1x50 pb, single-end run) por Ascidea Computational Biology Solutions (www.ascidea.com). La calidad de las lecturas se analizó con el programa FastQC y se filtraron las lecturas de 18 a 26 nts de longitud con Pearl Scripts. Se descartó el sRNA coincidente con las secuencias de RNA ribosomal y de transferencia en la base de datos Rfam. Los sRNAs que mapeaban en el genoma del virus o en los cDNAs de Arabidopsis (TAIR10) se obtuvieron con Bowtie. No se permitió ninguna disparidad.

\subsection{Clonación}

\subsubsection{Plásmidos base}

pCambia 2300 (www.cambia.org): Plásmido de alto número de copias utilizado para la expresión transitoria de genes en $N$. benthamiana mediada por Agrobacterium. Este plásmido contiene el gen nptII que aporta a las bacterias resistencia a la kanamicina. Posee el operón Lac $\mathrm{Z}$ en el sitio de clonación múltiple y el promotor constitutivo 35 del virus del mosaico de la coliflor (CaMV, Cauliflower mosaic virus). 
pSLJ75155 (Jones et al., 1992): Plásmido binario empleado para la expresión transitoria de genes en $N$. benthamiana mediada por Agrobacterium. Posee orígenes de replicación de E. coli y Agrobacterium, el gen de resistencia al antibiótico tetraciclina y el T-DNA del plásmido Ti con un sitio de clonación múltiple (MCS, del inglés multiple cloning site) para el clonaje de la secuencia de interés.

pBGWFS7 (Karimi et al., 2002): Plásmido binario de destino que emplea tecnología Gateway para el análisis de promotores. El cassette de expresión contiene la proteína de fusión reportera $\beta$-glucuronidasa (GUS) y GFP. Contiene el marcador de selección en planta BASTA y los genes de resistencia a los antibióticos streptomicinaspectinomicina.

pDONR207: Vector donante del sistema de clonaje Gateway con las secuencias sttP1 y attP2. Posee los genes de resistencia a la gentamicina y cloramfenicol. Se empleó como vector donante para el pGWB14.

pGWB14: Plásmido binario Gateway empleado para la expresión transitoria de genes en $N$. benthamiana mediada por Agrobacterium. Posee un promotor de expresión constitutivo 35 de CaMV, el epítopo HA y los genes de resistencia a kanamicina e higromicina.

pDONR221: Vector donante del sistema de clonaje Gateway con las secuencias sttP1 y attP2. Posee los genes de resistencia a la kanamicina y cloramfenicol. Se empleó como vector donante para el $\mathrm{pH} 7 \mathrm{~m} 34 \mathrm{GW}$.

pH7m34GW: Vector Gateway binario empleado en clonación por recombinación de tres fragmentos para generación de plantas transgénicas. Expresa los genes de resistencia a spectinomicina e higromicina.

\subsubsection{Otras construcciones}

pSLJ-HAGFP: Plásmido derivado del pSLJ75155 al que se le ha introducido en el sitio de clonación múltiple el cassette de expresión de un plásmido pRTL2 que contenía el ORF completo del gen que codifica la proteína soluble modificada GFP con el codón de terminación y el epítopo HA.

pSLJ-dsGFP (Chisholm et al., 2000): Plásmido derivado del pSLJ75155 al que se le ha introducido en el sitio de clonación múltiple el cassette de expresión de un plásmido pRTL2 que contenía dos copias en orientación sentido y antisentido del ORF completo del gen que codifica la proteína soluble modificada GFP. Ambas hebras están separadas por 1 intrón de 120 nts del gen RTM1 de Arabidopsis (Johansen and Carrington, 2001). Se trata de un sistema de expresión diseñado para producir dsRNAs en plantas. 
pCambia-HAGFP: Plásmido derivado del pCambia 2300 al que se le ha introducido en el sitio de clonación múltiple el ORF completo de la proteína soluble modificada GFP con su codón de terminación precedido del epítopo HA.

pCambia-GUS: Plásmido derivado del pCambia2.300 al que se le ha introducido en el sitio de clonación múltiple el ORF completo de la GUS.

pCambia-HC-Pro (Goytia et al., 2006): Plásmido derivado del pCambia2.300 que incorpora un fragmento de 2.924 nucleótidos del genoma del virus del grabado del tabaco (TEV) que incluye la región P1, HC-pro y parte de la región P3 del virus.

\subsubsection{Clonación con enzimas de restricción}

Para generar los distintos clones empleados en esta tesis partimos de productos de PCR que purificamos mediante el kit comercial "GENECLEAN Turbo" (MP Biomedicals). A continuación digerimos el producto de PCR purificado y el plásmido de clonaje con las enzimas de restricción elegidas según el mapa de restricción de cada secuencia para cada caso. Los productos de digestión se ligaron al vector en una proporción de DNA inserto y vector de 3:1 durante toda la noche a $4^{\circ} \mathrm{C}$ empleando la DNA ligasa del fago T4 (Promega).

A continuación se transformaron células electrocompetentes de E. coli DH5 $\alpha$ por electroporación aplicando un voltaje de $2,5 \mathrm{Kv}$ a una resistencia de $600 \Omega$ y a una capacitancia de $10 \mu \mathrm{f}$ empleando un microlitro de la mezcla de ligación. Las bacterias transformadas se cultivaron en placas de LB-Agar (bacto-triptona a $10 \mathrm{~g} / \mathrm{L}$, extracto de levadura a $5 \mathrm{~g} / \mathrm{L}, \mathrm{NaCl}$ a $10 \mathrm{~g} / \mathrm{L}$ y agar a $20 \mathrm{~g} / \mathrm{L}$ ) con el antibiótico de selección durante 24 horas a $37^{\circ} \mathrm{C}$. Las colonias resistentes al antibiótico de selección se seleccionaron para su análisis por PCR usando cebadores específicos del inserto y del vector. Por último se purificó el DNA plasmídico de las colonias seleccionadas y se secuenció para asegurar la integridad del inserto clonado. Con el plásmido purificado se transformaron bacterias electrocompetentes de Agrobacterium por electroporación aplicando un voltaje de $2,2 \mathrm{Kv}$ a una resistencia de $200 \Omega$ y a una capacitancia de $25 \mu \mathrm{f}$. Las células transformadas se cultivaron en placas de LB-Agar con los antibióticos de selección durante 48 horas a $28^{\circ} \mathrm{C}$ para aislar unidades formadoras de colonias.

\subsubsection{Clonación con sistema GATEWAY}

En los clonajes que requirieron la tecnología de clonaje Gateway se realizó una PCR a partir del producto de cDNA de interés para obtener el fragmento a clonar. Para ello se emplearon cebadores específicos de la secuencia de interés que incorporaban los extremos attB1 y attB2. El producto de PCR se clonó en un plásmido pDONR207 a 
través de un proceso de recombinación bajo la acción de la clonasa II BP (Gateway Technology, Invitrogen). La secuencia a clonar se transfirió después hasta el vector binario de destino pGWB14, a través de una reacción de recombinación asistida por la clonasa II LR (Invitrogen). El vector resultante se empleó para transformar células de Agrobacterium como se describe en el apartado 3.3.3. La fidelidad de todos los clones definitivos se confirmó mediante la elaboración de mapas de restricción, secuenciación y expresión transitoria en $N$. benthamiana.

\subsubsection{Mutagénesis dirigida por PCR}

Las mutaciones en la secuencia de BIRl (A, B, C y D) se generaron por mutagénesis dirigida por PCR tal y como se describe en (Ho et al., 1989). Se empleó la construcción pENTRY-BIR1 como molde y cebadores mutagénicos que incorporaban los cambios en los nucleótidos descritos en cada una de las supuestas dianas de corte. La estrategia comprende tres PCRs, la primera contiene un cebador directo de secuencia homóloga al inicio de la secuencia de BIR1 unida a la secuencia adaptadora attB1 para su clonaje posterior al pDONR207 y un cebador reverso de la secuencia complementaria a BIR1 en el punto a mutar con las mutaciones incorporadas. La segunda PCR contiene un cebador directo con la secuencia homóloga al punto que se desea mutar con las mutaciones puntuales incorporadas y un cebador reverso complementario al final de la secuencia de BIR1 unido al adaptador attB2. La tercera PCR emplea como molde las PCRs anteriores y como cebadores attB1 y attB2. El producto de la PCR3 se purificó y clonó en pDNOR207 usando tecnología Gateway. En el caso de los mutantes que incorporaban mutaciones simultáneas en varios puntos se realizó una mutagénesis secuencial empleando el producto de la PCR3 como molde para la siguiente mutagénesis dirigida por PCR.

\subsubsection{Mantenimiento de clones}

Todos los clones seleccionados se cultivaron en medio LB líquido con los antibióticos de selección durante 48 horas a $28^{\circ} \mathrm{C}$ en el caso de Agrobacterium y 24 horas a $37^{\circ} \mathrm{C}$ en el caso de E. coli. Una alícuota de estos cultivos en su fase exponencial se guardó a $-80^{\circ} \mathrm{C}$ en glicerol al $10 \%$. 


\subsection{Análisis de proteínas}

\subsubsection{Purificación de proteínas}

Las proteínas totales se extrajeron del tejido vegetal mediante su homogenización en nitrógeno líquido, con ayuda de un mortero y adición del tampón de extracción de proteínas $(10 \%$ de glicerol, $3 \%$ de SDS, Tris- $\mathrm{HCl}$ a $62 \mathrm{mM} \mathrm{pH} 8,0$ y $1 \%$ de $\beta$ mercaptoetanol) en una proporción de $400 \mu \mathrm{l}$ de tampón por cada $100 \mathrm{mg}$ de tejido fresco. El extracto se clarificó a $12.000 \mathrm{rpm}$ y el sobrenadante se añadió a una solución

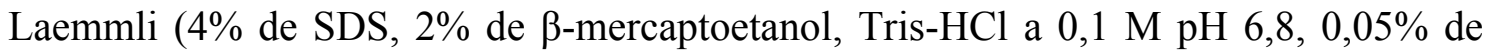
$\mathrm{BPB}, 20 \%$ de glicerol). Las muestras se incubaron a $95^{\circ} \mathrm{C}$ durante 5 minutos y se centrifugaron a máxima velocidad durante 2 minutos.

\subsubsection{Western blot}

Las muestras de proteína total purificada se analizaron por SDS-PAGE en geles desnaturalizantes de poliacrilamida al 10-12\% empleando el soporte "Mini-Protean II" (BioRad). Las proteínas se transfirieron a membranas de PVDF Hybond-P (GE Healthcare Life Sciences) mediante el soporte "Mini Trans-Blot Cell" (BioRad) y se tiñieron con Rojo Ponceau ( $0,1 \%$ de Ponceau-S en ácido acético al $5 \%)$ para visualizar la subunidad grande de la proteína Rubisco (55 KDa) que se empleó como normalizador de carga. Las membranas se bloquearon en una solución de tampón fosfato salino (PBS) con leche desnatada al 10\% durante $3 \mathrm{~h}$. La incubación con el anticuerpo primario se realizó a la dilución recomendada por el fabricante durante toda la noche a $4^{\circ} \mathrm{C}$. Para los anticuerpos anti-HA y anti-GFP se emplearon diluciones 1:10.000 mientras que para los anti-mCherry y anti-MAPK fosforiladas se emplearon diluciones 1:500 y 1:2.000 respectivamente. Como anticuerpo secundario se emplearon anti-rata o anti-conejo conjugado con peroxidasa durante un mínimo 4 horas a temperatura ambiente. El revelado de la actividad peroxidasa se llevó a cabo mediante el sistema de ECL (Amersham Biosciences) de detección de quimiluminiscencia exponiendo las películas "CP-BU medical x-ray film blue" (AGFA) a las membranas. Entre los distintos pasos las membranas se lavaron tres veces con solución de lavado PBS-T (10\% de PBS y $0,5 \%$ de Tween-20) durante 10 minutos.

En aquellos casos en los que se requirió cuantificar la señal revelada del western blot se analizaron las bandas de hibridación obtenidas en las películas mediante densitometría empleando un escáner "GS800 Calibrated Densitometer" (BioRad) y el programa Quantity One version 4.2.3 (BioRad). 


\subsubsection{Estudio de localización subcelular mediante microscopía laser confocal}

La localización subcelular de las proteínas de fusión BIR1:mCherry se llevó a cabo empleando un microscopio confocal Leica TCS SP5. La línea del láser de excitación para la formación de imágenes de las proteínas quiméricas con mCherry fue $561 \mathrm{~nm}$.

\subsubsection{Tinción histoquímica de GUS}

La detección histoquímica de GUS se realizó como en (Jefferson et al., 1987). Las hojas de roseta de Arabidopsis se fijaron en acetona al 90\% durante 20 minutos a temperatura ambiente, se lavaron 5 veces con tampón fosfato $100 \mathrm{mM} \mathrm{pH} 8,0$ y se incubaron 16 horas a $37^{\circ} \mathrm{C}$ en una solución con tampón fosfato sódico a $50 \mathrm{mM} \mathrm{pH} \mathrm{7,2,}$ 5-bromo-4-chloro-3-indolyl- $\beta$-D-glucuronide (X-gluc) a $2 \mathrm{mM}, 0,2 \%$ de triton $\mathrm{x}-100$, Ferrocianida a $5 \mathrm{mM}$ y Ferricianida a $5 \mathrm{mM}$. Se realizaron lavados de 20 minutos a temperatura ambiente y una ligera agitación con diluciones de etanol a concentraciones crecientes $(25 \%, 50 \%, 70 \%$ y $95 \%)$.

\subsubsection{Tinción con azul de tripano}

Para la observación directa de muerte celular en hojas de Arabidopsis se empleó la tinción con azul de tripano según se describe en (Hamberg et al., 2003). Se utilizó una solución de lactofenol con ácido láctico (Panreac), fenol (Amresco) y glicerol al 87\% (Merk) en agua y se añadió azul de tripano (Fluka) a $0,25 \mathrm{mg} / \mathrm{mL}$. Para obtener la solución de tinción se diluyó la solución resultante en etanol absoluto (1:2). Las hojas de Arabidopsis se cubrieron con la solución de tinción y se hirvieron en un baño a $95^{\circ} \mathrm{C}$ durante 1 minuto tras lo cual se incubaron a temperatura ambiente durante 45 minutos. Para eliminar la solución de tinción se lavaron las hojas en una dilución saturada de cloral hidrato (Sigma-Aldrich) a 2,5 g/mL renovada cada 30 minutos hasta que dejó de desteñir y se incubó durante toda la noche. Posteriormente las muestras se transfirieron a una solución de glicerol al $60 \%$.

\subsection{Bases de datos y análisis estadístico}

\subsubsection{Bases de datos}

Se empleó el genoma anotado de Arabidopsis (TAIR10) de la base de datos TAIR (www.arabidopsis.org). Los datos de metilación del DNA (GSE39901) son de (Stroud et al., 2013). La secuenciación del degradoma de inflorescencias de Col-0 sanas (GSM280226) aparece citada en (German et al., 2008). Los datos de este estudio se entregaron al NCBI Gene Expression Omnibus (GEO; 
http://www.ncbi.nlm.nih.gov/geo/) bajo los números de accesión: GSE15557/155562/15558 (micromatrices de transcriptoma), GSE106322 (micromatrices de degradoma); GSM3019138, GSM3019139, GSM3019140 (secuenciación de degradoma); GSM2808011, GSM2808012， GSM3019141, GSM3019142 (secuenciación de sRNAs).

\subsubsection{Gráficas y análisis estadístico}

Salvo excepciones puntuales, para cada uno de los experimentos de esta tesis se realizaron al menos tres repeticiones/réplicas biológicas independientes. Las gráficas muestran los valores medios y la desviación estándar (SD, del inglés standard deviation) (barras de error) de las réplicas técnicas analizadas en cada réplica independiente. En la composición de cada figura se muestra una réplica biológica representativa de las demás. Salvo que se especifique lo contrario, cada muestra analizada en cada réplica en los diferentes ensayos consiste en un grupo de hojas recolectadas a partir de al menos cinco plantas diferentes.

El análisis estadístico de los datos obtenidos mediante PCR cuantitativa se realizó con el programa Statgraphics Plus versión 5.1. Previamente a la realización de los diversos test se comprobó la normalidad y la homocedasticidad de las distribuciones de datos de cada parámetro. En caso de no cumplirse alguno de estos requisitos, se aplicaron una serie de transformaciones matemáticas sobre los datos iniciales. Las diferencias entre la acumulación de transcritos en los análisis de qRT-PCR se realizaron mediante análisis de varianza de un factor (One-Way ANOVA) y posterior test de Duncan. Para la comparación de grupos dos a dos se aplicó el test $\mathrm{t}$ de Student. Para la comparación de más de dos grupos en los que al menos uno no cumplía la normalidad aplicamos el test de Kruskal-Wallis seguido de comparaciones dos a dos con U de Mann Whitney con el nivel de significación modificado con la corrección de Bonferroni. 


\begin{tabular}{|c|c|c|}
\hline Nombre & Secuencia $\left(5^{\prime}-3^{\prime}\right)$ & Uso \\
\hline $\mathrm{CaF}$ & GTGCACGCAACAGTTCTAATCG & \multirow{2}{*}{ RNA1 TRV } \\
\hline $\mathrm{CaR}$ & GCTGTGCTTTGATTTCTCCACC & \\
\hline TuMV-F & TGTTCGGCTTGGATGGAA & \multirow{2}{*}{ TuMV } \\
\hline TuMV-R & TTAACGTCCTCGGTCGTATGC & \\
\hline qRTACCU380Fw & ATCTCGGATTTCGGTCTAGC & \multirow{2}{*}{ mRNA BIR1 } \\
\hline qRTACCU380Rw & TCTTGAATACTCGGGAGCAAC & \\
\hline qFRK1F & AGCGGTCAGATTTCAACAGT & \multirow{2}{*}{ mRNA FRK1 } \\
\hline qFRK1R & AAGACTATAAACATCACTCT & \\
\hline qWRKY29F & ATCCAACGGATCAAGAGCTG & \multirow{2}{*}{ mRNA WRKY29 } \\
\hline qWRKY29R & GCGTCCGACAACAGATTCTC & \\
\hline qFWPR4720 & AGCTTCTTGCGGCAAGTGTTT & \multirow{2}{*}{ mRNA PR4 } \\
\hline qRWPR4720 & TGCTACATCCAAATCCAAGCC & \\
\hline BAK1 qRTPCR F & GACCTTGGGAATGCAAATCTATC & \multirow{2}{*}{ mRNA BAK1 } \\
\hline BAK1 qRTPCR R & AAAACTGATTGGAGTGAAAAGTGAAA & \\
\hline qFWPR1610 & CGTCTTTGTAGCTCTTGTAGG & \multirow{2}{*}{ mRNA PR1 } \\
\hline qRWPR1610 & TGCCTGGTTGTGAACCCTTAG & \\
\hline CBP20 qRTPCR F & GTGGCTTTTGTTTCGTCCTGTT & \multirow{2}{*}{ mRNA CBP20 } \\
\hline CBP20 qRTPCR R & GCCCCATTGTCTTCCTTCTTG & \\
\hline qPCR TUB F & GCTTACTAATCAAAGATGCG & \multirow{2}{*}{ mRNA Tubulina } \\
\hline qPCR TUB R & CTTGGTATCTTCCCGTCGAA & \\
\hline BIR2Fpair1 & TTGGCTACAGGGCTAAAAGC & \multirow{2}{*}{ mRNA BIR2 } \\
\hline BIR2Rpair1 & AGCTGTTTCACCCAATCCAC & \\
\hline qSOBIRF & TACCAGGAAGCAATGGGAAG & \multirow{2}{*}{ mRNA SOBIR } \\
\hline qSOBIRR & TCCССТTTTCCATGTACTCG & \\
\hline qDIN1-F & TGGTCATCGGCTATTTCTCC & \multirow{2}{*}{ mRNA DIN1 } \\
\hline qDIN1-R & GCTTGTTGTCGTTGCTTTCC & \\
\hline qDIN6-F & TTCCCTTGTTGCCTCCATC & \multirow{2}{*}{ mRNA DIN6 } \\
\hline qDIN6-R & TATTCCGCCACCTCTTTCC & \\
\hline qDIN11-F & CATGGGGACATCGGAAAG & \multirow{2}{*}{ mRNA DIN11 } \\
\hline qDIN11-R & TGATCCACCAAGGGCTAATG & \\
\hline
\end{tabular}

Tabla 2.1. Oligonucleótidos cebadores empleados en análisis de expresión génica por ensayos de qRTPCR. 


\begin{tabular}{|c|c|c|}
\hline \multicolumn{3}{|c|}{ CHOP-PCR } \\
\hline ChopBIR1F1 & CAGATGTACCCGCCAACCACGGTT & $\begin{array}{l}\text { mRNA BIR1 } \\
\text { CHOP_PCR v }\end{array}$ \\
\hline ChopBIR1R1 & GGTCACGAATGGCGGATTTGGCTT & CHOP-qPCR \\
\hline DdeI + digest cntrl F & CCTCGGATCTTTGGAGCATT & \\
\hline DdeI + digest cntrl $\mathrm{R}$ & TTTCTTGGAGCTTTCACATCTGTT & Contr \\
\hline DdeI - digest cntrl F & TCCAAGATTGAGGCCAAATTA & Control DAl \\
\hline DdeI - digest cntrl $\mathrm{R}$ & AAAAGGAGTGGCCAAGTTGGAA & Co \\
\hline $\mathrm{NlaIII}+$ digest cntrl F & GATTTTGATATTGTTACAGCATTGTT & \\
\hline NlaIII + digest cntrl R & TCCATATTCAGTACTTTTTAACCTACC & Fiame \\
\hline NlaIII - digest cntrl F & ACCGTTTGTTTATGTAGGGCGAAA & Control - NlaIII \\
\hline NlaIII - digest cntrl R & AAGATAACAGAAAAGACGATGATGACG & Controi - Niam \\
\hline \multicolumn{3}{|c|}{ CHOP-qPCR } \\
\hline DdeI + digest cntrl F & CCTCGGATCTTTGGAGCATT & \multirow{2}{*}{ Control + DdeI } \\
\hline DdeI + digest cntrl $\mathrm{R}$ & TTTCTTGGAGCTTTCACATCTGTT & \\
\hline DdeI - digest cntrl F & GAGAGATTCAGATGCCCAGAAGTC & \multirow{2}{*}{ Control - DdeI } \\
\hline DdeI - digest cntrl R & TGGATTCCAGCAGCTTCCA & \\
\hline $\mathrm{NlaIII}+$ digest $\operatorname{cntrl} \mathrm{F}$ & GATTTTGATATTGTTACAGCATTGTT & \multirow{2}{*}{ Control + NlaIII } \\
\hline NlaIII + digest cntrl R & TCCATATTCAGTACTTTTTAACCTACC & \\
\hline NlaIII - digest cntrl F & ACCGTTTGTTTATGTAGGGCGAAA & \multirow{2}{*}{ Control - NlaIII } \\
\hline NlaIII - digest cntrl R & AAGATAACAGAAAAGACGATGATGACG & \\
\hline \multicolumn{3}{|c|}{ Bisulfito } \\
\hline Bisulfito - cntrl F & TTTTGAGTTTTGATTTTTTTATGATAATT & Control - \\
\hline Bisulfito - cntrl R & ATTACAAATCTCCATAAAATAATACTT & Bisulfito \\
\hline Bisulfito BIR1 F1 & $\begin{array}{l}\text { TATAAAAATTGAATATTATGTTATATATTT } \\
\text { AAATAT }\end{array}$ & \multirow{2}{*}{$\begin{array}{l}\text { Bisulfito } \\
\text { Promotor BIR1 } \\
\text { frag.1 }\end{array}$} \\
\hline Bisulfito BIR1 R1 & $\begin{array}{l}\text { ATCTTTATATATAAACACTCTATAATCATC } \\
\text { TTA }\end{array}$ & \\
\hline Bisulfito BIR1 F2 & $\begin{array}{l}\text { TAGAGATTTTAATATTATGTAGATTAAGA } \\
\text { GTATATT }\end{array}$ & \multirow{2}{*}{$\begin{array}{l}\text { Bisulfito } \\
\text { Promotor BIR1 } \\
\text { frag. } 2\end{array}$} \\
\hline Bisulfito BIR1 R2 & $\begin{array}{l}\text { AAATTCTACAATTATATTATATATAATAA } \\
\text { ATAATTTAA }\end{array}$ & \\
\hline \multicolumn{3}{|c|}{ Transcritos de PolV } \\
\hline PolV + cntrl F & TGGTCCATAGGTTCGGAATTT & \multirow{2}{*}{$\begin{array}{l}\text { Control }+ \\
\text { transcritos PolV }\end{array}$} \\
\hline PolV + cntrl R & GGCATGGTTTGATATCAGGAG & \\
\hline PolVBIR1qPCR F1 & CGTGATTGACGATATTGATTCTCT & Transcritos PolV \\
\hline PolVBIR1qPCR R1 & ACTAGAGGTTGTGATTCGTGGTTT & promotor BIR1 \\
\hline
\end{tabular}

Tabla2.2. Oligonucleótidos cebadores empleados los experimentos de regulación transcripcional. 
3. RESULTADOS 



\section{RESULTADOS}

\subsection{Análisis de la expresión de $B I R 1$ en plantas infectadas con virus}

Como paso previo en el estudio del papel que desempeña BIRl durante las infecciones virales monitorizamos su expresión en el transcurso de la infección. Mediante qRT-PCR detectamos un aumento significativo en la acumulación de transcritos de BIRl a los 5 y 8 días post-inoculación (dpi) en hojas de roseta infectadas con TRV en comparación con plantas control inoculadas con extracto de planta sana (Figura 3.1A). El mensajero de BIRl también se acumulaba más durante la infección con TuMV que en las plantas control, lo que sugiere que su inducción es una respuesta general a la infección por virus (Figura 3.1B).

A

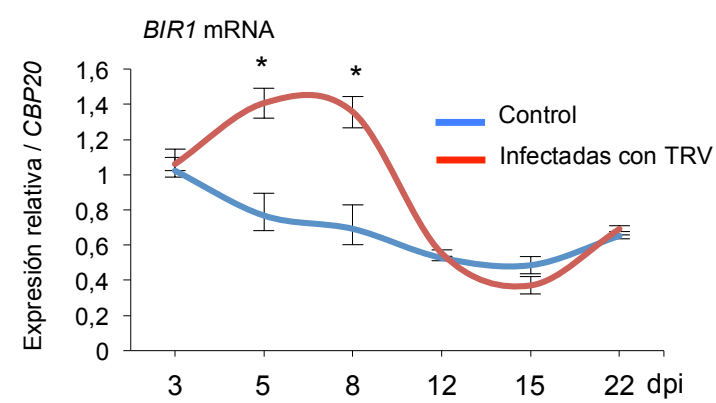

B

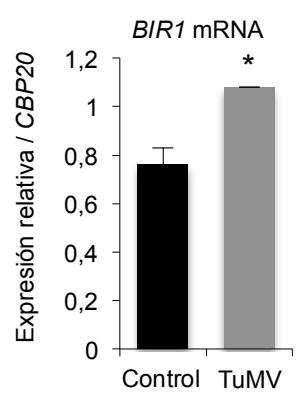

Figura 3.1. A) Acumulación relativa, mediante qRT-PCR, de transcritos de BIRl a distintos tiempos post-inoculación (dpi) en hojas de roseta de Arabidopsis silvestres infectadas con TRV e inoculadas con extracto de hoja sana. Los valores se relativizaron respecto a la muestra control a los 3 dpi (valor 1.0). B) Acumulación relativa, mediante qRT-PCR, de transcritos de BIRl en hojas de roseta de Arabidopsis silvestres infectadas con TuMV o inoculadas con extracto de planta sana (control) a los 14 dpi. Las diferencias entre las plantas control e infectadas se consideraron significativas con $P<0,001\left(^{*}\right)$.

Cuando se infectaron con TRV plantas de Arabidopsis mutantes birl-1 con pérdida de función para el gen BIRl observamos niveles mínimos de acumulación viral en comparación con los observados en hojas de roseta de Arabidopsis silvestres infectadas (Figura 3.2A). Estos resultados indicaban que la pérdida de BIRl acarreaba un fenotipo de resistencia antiviral frente a TRV (Figura 3.2A) (Gao et al., 2009). Los niveles de acumulación de TRV volvieron a los niveles de plantas silvestres, o incluso mayores, en las líneas birl-1 complementadas (bir1-1/BIR1-HA) que expresaban la región codificadora del BIR1 silvestre con un marcador HA (Figura 3.2A). Este resultado confirmaba que el fenotipo de resistencia observado en el mutante birl-1 era causado por la mutación en BIRl. Ensayos de Western blot con el anticuerpo anti-HA revelaron una inducción significativa de proteína BIR1 en las líneas bir1-1/BIRl-HA después de 
la infección de TRV (a 8dpi), lo que indica que los niveles elevados de transcritos se reflejan en niveles elevados de proteína en las hojas infectadas sistémicamente (Figura 3.2B). Dado que el mutante birl-1 presenta activadas de forma constitutiva las respuestas de defensa y muerte celular (Gao et al., 2009), cabría esperar una mayor acumulación de transcritos de genes relacionados con la defensa. Para comprobarlo medimos usando qRT-PCR la acumulación de RNA mensajero de los genes PATHOGENESIS RELATED 1 (PRI), PATHOGENESIS RELATED 4 (PR4), PHYTOALEXIN DEFICIENT 3 (PAD3) y WRKY DNA-BINDING PROTEIN 29 (WRKY29) durante la infección con TRV. PRl y PR4 participan en la respuesta de defensa mediada por SA y etileno, respectivamente (Potter et al., 1993; Durrant and Dong, 2004; Guevara-Morato et al., 2010; Breen et al., 2017). PAD3 esta implicado en la biosíntesis de camalexina en respuesta a infecciones microbianas mientras que WRKY7 y otras proteínas WRKY de unión a DNA regulan la transcripción del receptor de SA NPR1 y de otros genes de defensa con actividad antimicrobiana (Yu et al., 2001). Nuestros resultados confirmaron que estos genes estaban sobreexpresados en plantas birl-1 infectadas respecto al genotipo silvestre, e indicaban que la infección por TRV no inhibía la activación constitutiva de las defensa cuando BIRl estaba desactivado genéticamente (Figura 3.3).

A

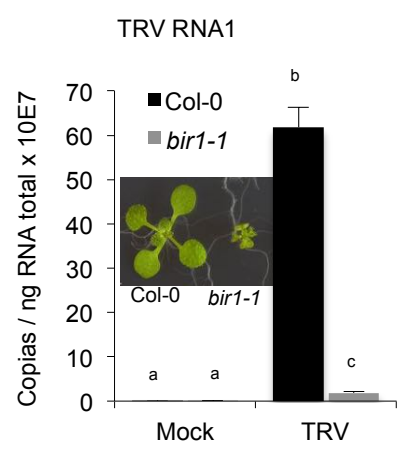

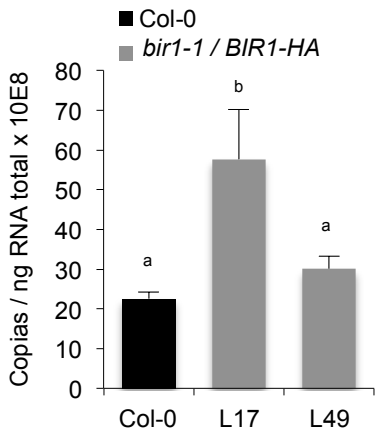

B

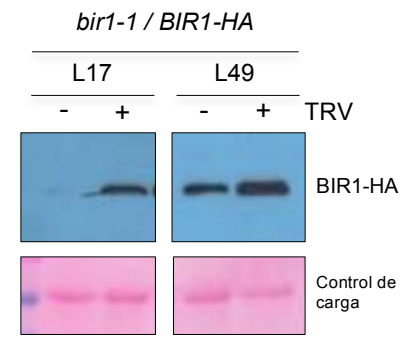

Figura 3.2. A) Acumulación, mediante qRT-PCR, de RNA1 genómico de TRV en hojas de roseta de Arabidopsis silvestres (Col-0), mutantes birl-1 y dos líneas de complementación bir1-1/BIR1-HA (L17 y L49) a 8 dpi. Los controles inoculados con extracto de planta sana se incluyeron en el panel de la izquierda para discriminar la amplificación de fondo. Se muestra el fenotipo del fondo silvestre y del mutante bir $1-1$ en plantas sembradas en medio MS-MES a $21^{\circ} \mathrm{C}$. Las distintas letras indican diferencias estadísticamente significativas $(P<0,001)$. B) Determinación, mediante Western blot, de los niveles de proteína BIR1-HA en hojas de roseta de Arabidopsis de las líneas de complementación L17 y L49 inoculadas con extracto de planta sana (-) o infectadas con TRV (+). Las membranas se incubaron con anticuerpo anti-HA. La membrana teñida con rojo Ponceau se muestra como control de carga. 

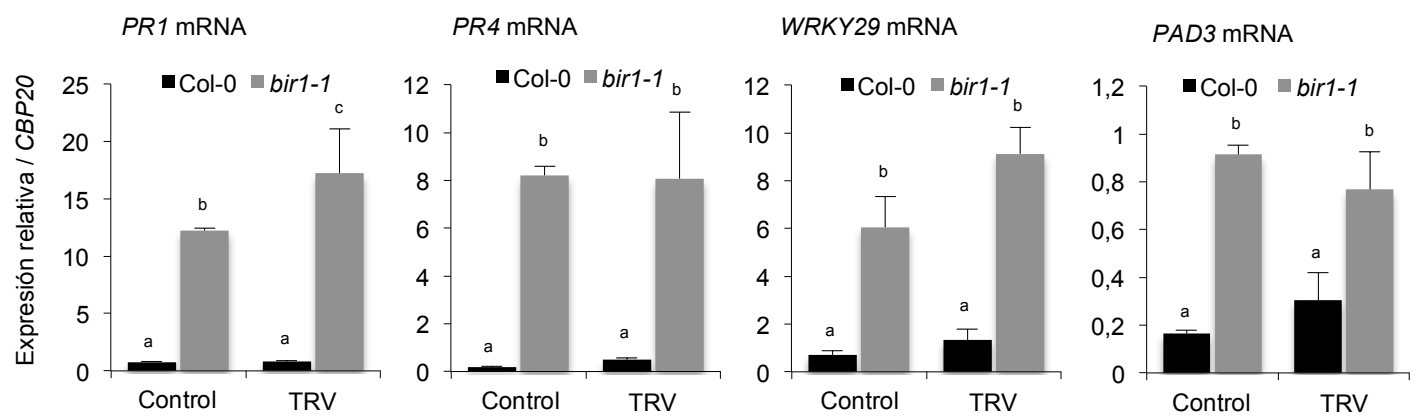

Figura 3.3. Acumulación relativa, mediante qRT-PCR, de transcritos de los genes de defensa $P R 1, P R 4$, $P A D 3$ y WRKY7 en hoja de roseta de Arabidopsis silvestres (Col-0) y de los mutantes birl-1 inoculados con TRV y con extracto de planta sana (control) a los 8 dpi. Las distintas letras indican diferencias estadísticamente significativas $(P<0,001)$.

El fenotipo autoinmune en los mutantes birl-1 dependen parcialmente de SOBIR1, el cual promueve la muerte celular y la defensa en conjunción con BAK1 (Chinchilla et al., 2007; Gao et al., 2009; Liu et al., 2016). Mediante qRT-PCR observamos que SOBIRl mostraba niveles de transcritos más altos en plantas infectadas y a varios tiempos después de la inoculación que en plantas control inoculadas con tampón (Figura 3.4A), mientras que $B A K 1$ disminuía a lo largo de la infección respecto a las plantas no infectadas (Figura 3.4B). La inducción de SOBIR1 y la represión de BAK1 también fue evidente en plantas infectadas con TuMV (Figura 3.4C) (Figura 3.4D). Cuando analizamos los niveles de acumulación de TRV en plantas mutantes bak1-5, en donde la señalización inmune (PTI) es deficiente, observamos una mayor susceptibilidad a la acumulación viral que en el genotipo silvestre (Figura 3.5A), mientras que los niveles de TRV estaban reducido ligeramente en los mutantes sobir1-12 (Figura 3.5B). 
A

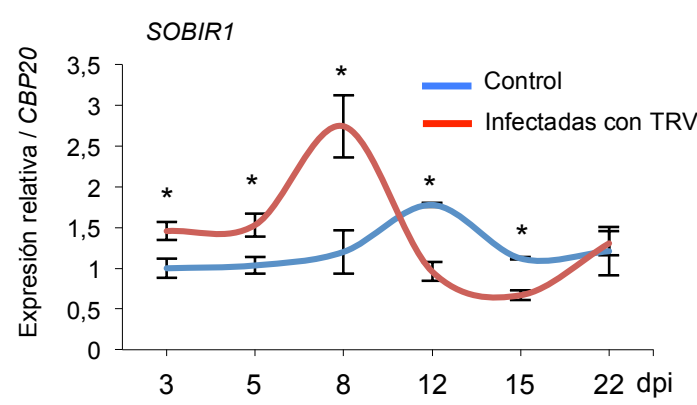

B

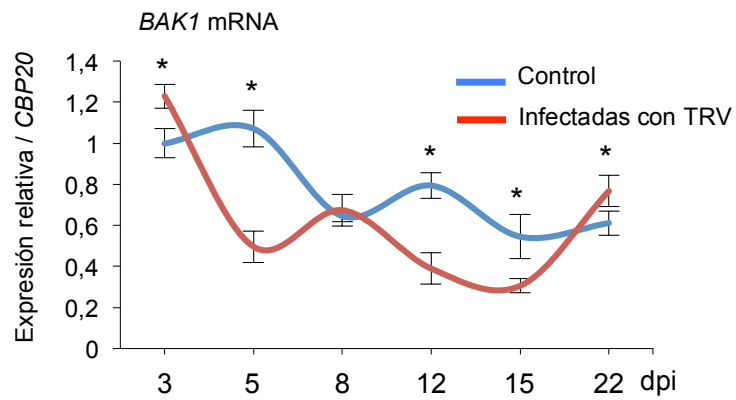

C
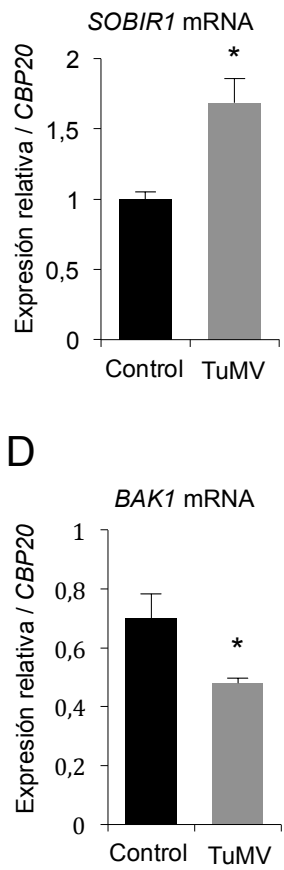

Figura 3.4. Acumulación relativa, mediante qRT-PCR, de transcritos de SOBIR1 (A) y BAK1 (B) a distintos tiempos post-inoculación (dpi) en hojas de roseta de Arabidopsis silvestres infectadas con TRV e inoculadas con extracto de planta sana (control). Los valores se relativizaron respecto a la muestra control a los 3 dpi (valor 1.0). Acumulación relativa, mediante qRT-PCR, de transcritos de SOBIRI (C) y $B A K 1$ (D) en hojas infectadas con TuMV o inoculadas con extracto de planta sana a los 14 dpi. Las diferencias entre las plantas control e infectadas se consideraron significativas con $P<0,001\left(^{*}\right)$.

A

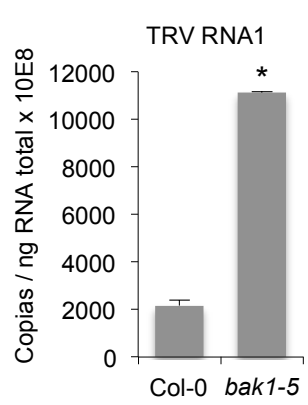

B

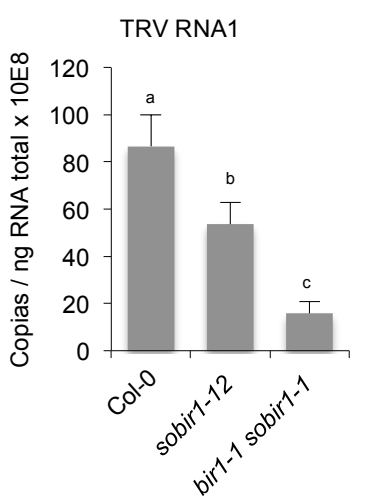

Figura 3.5. Acumulación, mediante qRTPCR, del RNA1 genómico de TRV en hojas de roseta de Arabidopsis silvestres (Col-0) y mutantes bakl-5 (A) ó en los mutantes sobir1-12 y birl-1 sobirl-1 (B) a 8 dpi. Las distintas letras indican diferencias estadísticamente significativas, $P<0,05)$.

\subsection{Efecto de la muerte celular y de la defensa mediada por SA en la resistencia antiviral de los mutantes bir1-1}

El fenotipo de resistencia antiviral asociado a la pérdida de función de $B I R 1$ podría ser consecuencia de la activación constitutiva de la muerte celular o de la defensa mediada por SA observada en los mutantes bir1-1 (Gao et al., 2009; Wierzba and Tax, 2016). La pérdida de función de SOBIR 1 suprime parcialmente la morfología de bir1-1, y contribuye a reducir de forma significativa la acumulación de genes de defensa y la 
muerte celular (Gao et al., 2009; Liu et al., 2016). Curiosamente los niveles de TRV se encontraban reducidos drásticamente en el doble mutante birl-1 sobirl-1 (Figura 3.5B). Este resultado sugiere que la resistencia a TRV en el mutante birl-1 no estaba relacionada con la muerte celular constitutiva o la defensa mediada por SA. En congruencia con este resultado, observamos que la aplicación exógena de SA dispara la acumulación de transcritos de $P R l$ en el tejido de la planta silvestre pero de forma insuficiente como para iniciar una respuesta antiviral efectiva frente a TRV (Figura 3.6). Estos resultados sugieren que TRV desencadena una respuesta inmune en la cual BIR1 parece actuar como regulador negativo de la defensa antiviral.
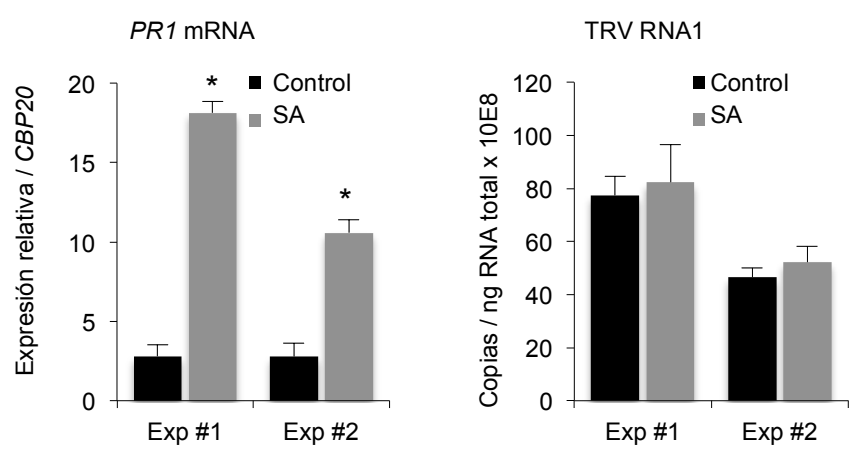

Figura 3.6. Acumulación, mediante
qRT-PCR, de transcritos de PRl
(izquierda) y de RNA1 genómico de
TRV (derecha) en hojas de roseta de
Arabidopsis silvestres tratadas con o sin
(control) SA. Exp\#1 y Exp\#2 se
describen en el apartado 3.2 .4 de
Materiales y métodos. Las diferencias
con el fondo silvestre se consideraron
significativas con $P<0,001(*)$.

Para determinar si esta función de defensa de BIRl pudiera extenderse a otros miembros de la familia génica, exploramos el fenotipo de susceptibilidad/resistencia en un mutante de pérdida de función para el gen homólogo BIR2. Los resultados obtenidos por qRT-PCR muestran una menor proliferación viral en plantas del mutantes bir2-1 que en plantas silvestres, lo que sugiere que distintos miembros de la familia génica BIR podrían regular elementos comunes en la vía de señalización (Figura 3.7).

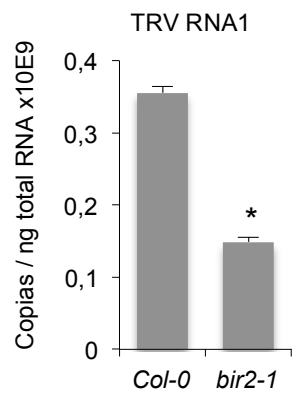

Figura 3.7. Acumulación, mediante qRT-PCR, de RNA1 genómico de TRV en hojas de roseta de Arabidopsis silvestres (Col-0) y del mutante bir2-1 a 8 dpi. Las diferencias con el fondo silvestre se consideraron significativas con $P<0,001$ $(*)$. 


\subsection{Regulación transcripcional de BIRI}

\subsubsection{Efecto del SA en la expresión de BIRI}

La expresión constitutiva de los genes $P R$ y la muerte celular en los mutantes birl1 se asocia con un aumento significativo en los niveles de SA (Gao et al., 2009). Con el fin determinar el efecto de esta molécula señalizadora en la expresión de BIRl analizamos la acumulación de transcritos en plantas silvestres de Arabidopsis tratadas con SA. Los resultados obtenidos por qRT-PCR mostraban niveles de RNA mensajero de $B I R 1$ mayores en plántulas tratadas respecto al control pulverizado con agua (Figura 3.8A). Para estudiar si el efecto del SA sobre la expresión de BIRl es el resultado de la activación transcripcional de su promotor, generamos plantas transgénicas de Arabidopsis que expresaban una proteína de fusión GUS:GFP bajo el control del

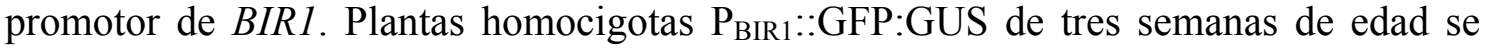
pulverizaron con SA y la expresión del transgén en hojas de roseta se analizó a las 6, 12 y $24 \mathrm{~h}$ después del tratamiento. Mediante un ensayo de hibridación Northern blot empleando una sonda específica frente a la GFP pudimos apreciar mayores niveles de acumulación de transcritos GFP:GUS a los tres tiempos analizados tras el tratamiento con SA respecto a las muestras control (Figura 3.8B). El pico de respuesta a SA lo detectamos a las $6 \mathrm{~h}$ post-tratamiento, mientras que a tiempo 0 la acumulación de BIR1 era idéntica en plantas tratadas y no tratadas (Figura 3.8B). Estos resultados demuestran que el SA es capaz de activar la transcripción de BIRl.

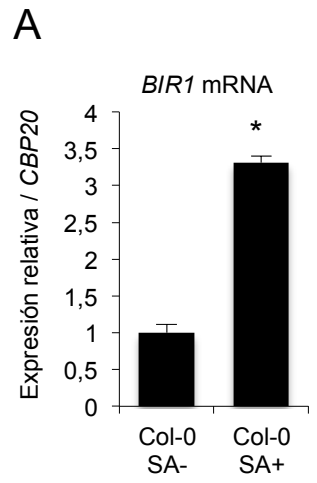

B

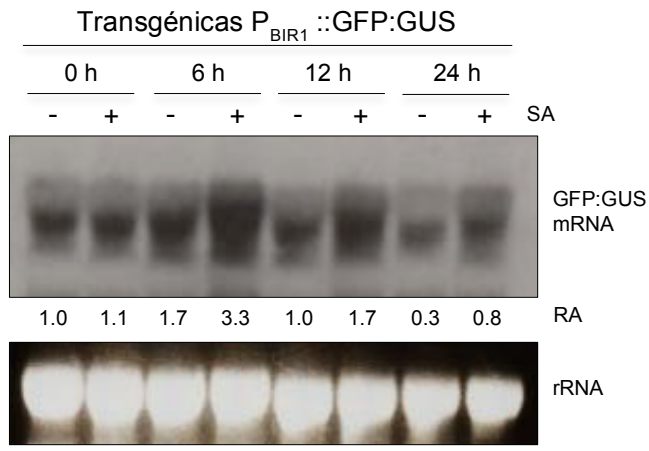

Figura 3.8 A) Acumulación relativa, mediante qRT-PCR, de transcritos de $B I R 1$ en hoja de roseta de Arabidopsis silvestres (Col-0) a las $8 \mathrm{~h}$ de ser pulverizadas con SA (+) o con agua como control (-). Los valores obtenidos se relativizaron con respecto a la muestra (-) (valor 1.0). Las diferencias se consideraron significativas con $P<0,001(*)$. B) Determinación, mediante Northern blot, de los niveles de transcrito GFP:GUS en plantas $\mathrm{P}_{\mathrm{BIR} 1}:$ GFP:GUS a las $0,6,12$ y $24 \mathrm{~h}$ de ser pulverizadas con SA (+) o con agua como control (-). Los valores de acumulación (RA), relativizados respecto a la muestra $0 \mathrm{~h} /-$ (valor 1.0), se obtuvieron mediante análisis densitométrico de las señales de hibridación. Para detectar el transcrito se empleó una sonda marcada radioactivamente específica de GFP. 
De nuestras observaciones se deduce que la inducción transcripcional de BIRl durante la infección viral pudiera deberse a un incremento en la acumulación de SA en los tejidos infectados. Esta idea es realista dado que la infección por TRV se asocia con la regulación positiva de los genes ISOCHORISMATE SYNTHASE 1 (ICS1) y PAD4 implicados directamente en la biosíntesis de SA (Figura 3.9A) (Chen et al., 2009; Fernandez-Calvino et al., 2014) (GSE15557). Para comprobar esta hipótesis determinamos los niveles de SA en plantas infectadas y en plantas control mediante GC-TOF-MS (Vallarino and Osorio, 2016). Para ello se analizaron 4 réplicas biológicas por tratamiento (plantas no inoculadas, inoculadas con extracto de planta sana e infectadas con TRV) siendo cada réplica un conjunto de hojas recolectadas de al menos 6 plantas. Las muestras se recogieron a los 5, 8 y 14 dpi. Los resultados del experimento muestran niveles de hormona comparables entre tratamientos a los 5 dpi (Figura 3.9B). Sin embargo, los niveles de SA se dispararon en plantas infectadas a los $8 \mathrm{y}$, especialmente, 14 días tras la inoculación con TRV respecto a las plantas no infectadas (Figura 3.9B) Estos resultados validan nuestra hipótesis de que la inducción de BIRI durante la infección se asocia con los altos niveles de SA acumulados en los tejidos infectados.

A

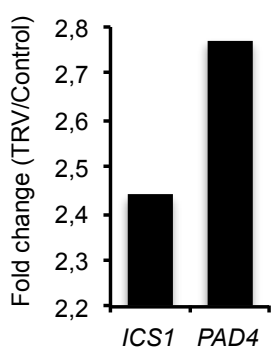

B

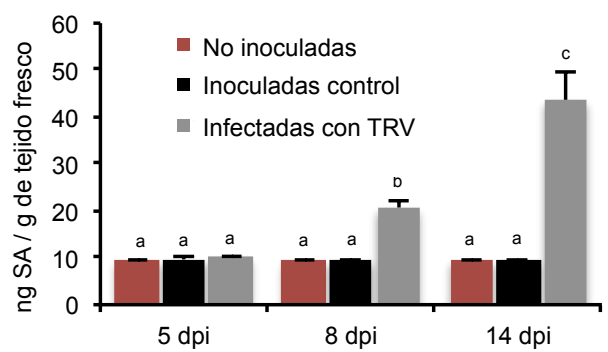

Figura 3.9. A) Expresión diferencial de los genes de biosíntesis de SA ICS1 y PAD4. Se muestra el Foldchange $\left(\log _{2}\right)$ detectado en plantas infectadas con TRV relativo a plantas inoculadas con extracto de planta sana empleando un microarray CATMA (GSE15557) (Fernández-Calvino et al., 2014) B) Acumulación de la hormona SA en hojas de roseta de Arabidopsis silvestres (Col-0) no inoculadas (sanas), inoculadas con extracto de planta sana (control) o con TRV a los 5, 8 y 14 dpi. Las distintas letras indican diferencias estadísticamente significativas $(P<0,001)$.

Si la expresión de BIRl durante la infección por TRV es dependiente del SA, sería de esperar que la acumulación de transcritos de BIRl estuviera alterada en mutantes de biosíntesis y/o de señalización de SA. De acuerdo a esta predicción, la activación de BIRl producida durante la infección con TRV se encontraba inhibida en el mutante sid2-2. Este mutante es deficiente en el gen ICS1 y presenta una disminución sustanciosa en la producción de SA (Wildermuth et al., 2001) (Figura 3.10A). NPR1 es 
un receptor de SA en Arabidopsis y por tanto un regulador clave en la transducción de señales de defensa mediada por esta hormona (Wu et al., 2012). Ensayos de qRT-PCR mostraban una inducción significativa de $B I R l$ en respuesta a la infección tanto en plantas silvestres como en las líneas complementadas de NPR1 (OXNPR1) (Kinkema et al., 2000) (Figura 3.10B). Por el contrario, esta respuesta se vio comprometida en mutantes nprl-1 en los que la inducción de BIRl en presencia del virus estaba atenuada respecto a las plantas control (Figura 3.10B). Estos resultados confirman que el SA actúa como molécula señalizadora en la activación transcripcional de BIRl y que TRV facilita la expresión de BIRl incrementando los niveles de SA en el tejido infectado.

Curiosamente, los niveles de acumulación viral en el mutante sid2-2 fueron menores que en plantas silvestres, mientras que el mutante nprl-1 presenta mayor susceptibilidad a las infección con TRV (Figura 3.10C). Los resultados obtenidos sugieren que el SA carece de una función antiviral directa frente a TRV, pero apoyan un posible papel de NPR1 independiente de SA en el control de la infección por TRV.

A

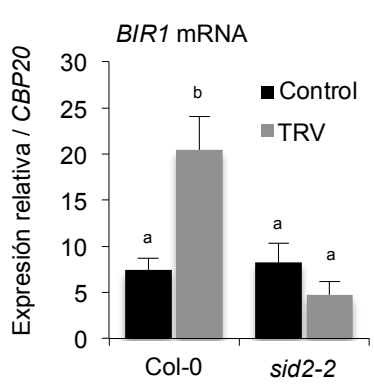

C
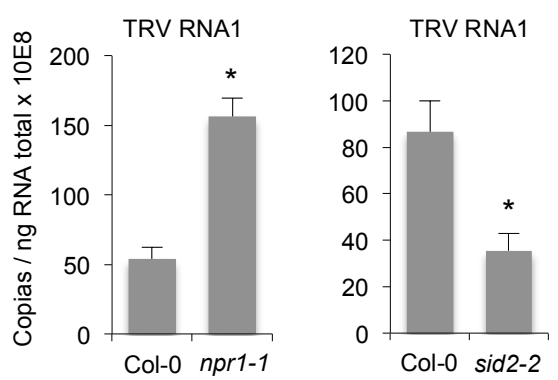

B

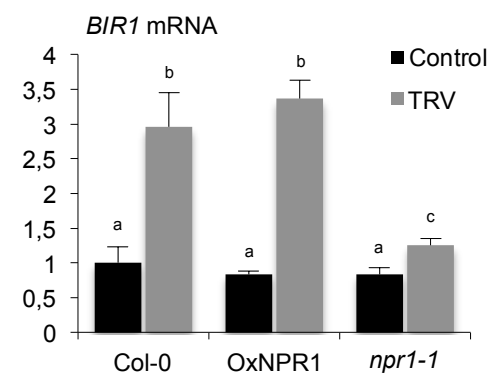

Figura 3.10 Acumulación relativa, mediante qRT-PCR, de transcritos de BIRl en hoja de roseta de Arabidopsis silvestres (Col-0) y en los mutantes sid2-2 (A) y nprl-1 (B) a 8 dpi. La línea de complementación OxNPRl se empleó como control. Las distintas letras indican diferencias estadísticamente significativas $(P<0,001) . \quad$ C) Acumulación, mediante qRT-PCR, del RNA1 genómico de TRV en hojas de roseta de Arabidopsis silvestres (Col-0) y en los mutantes sid2-2 y npr1-1 a 8 dpi. Las diferencias con el fondo silvestre se consideraron significativas con $P<0,001$ (*).

\subsubsection{Efecto de la metilación de DNA mediada por RNA (RdDM) en la regulación transcripcional de $B I R I$}

El análisis de los datos de secuenciación de pequeños RNAs de Arabidopsis generados en nuestro laboratorio reveló una copiosa acumulación de siRNAs aguas arriba del punto de inicio de la transcripción de BIRI (Figura 3.11). La mayoría de estos 
pequeños RNAs tenían un tamaño de 24 nts, lo que sugiere que la vía RdDM dependiente de siRNA podría desempeñar un papel relevante en el control transcripcional de BIRl (Figura 3.11). Para probar esta hipótesis cuantificamos mediante qRT-PCR la expresión relativa de $B I R l$ en una serie de mutantes defectivos en RdDM. Los resultados obtenidos mostraban que los transcritos de BIRI eran significativamente más abundantes en los mutantes drm2-2, drm1-2 drm2-2 cmt3-11t $(d d c)$, nrpel y ago4-1 en comparación con plantas silvestres (Figura 3.12). Por el contrario los niveles de expresión de BIR1 en el mutante cmt3-11t eran similares a los observados en plantas control (Figura 3.12). Estos resultados sugieren que, bajo condiciones normales de crecimiento y desarrollo, la vía $\mathrm{RdDM}$ ejerce un control transcripcional sobre $B I R 1$.

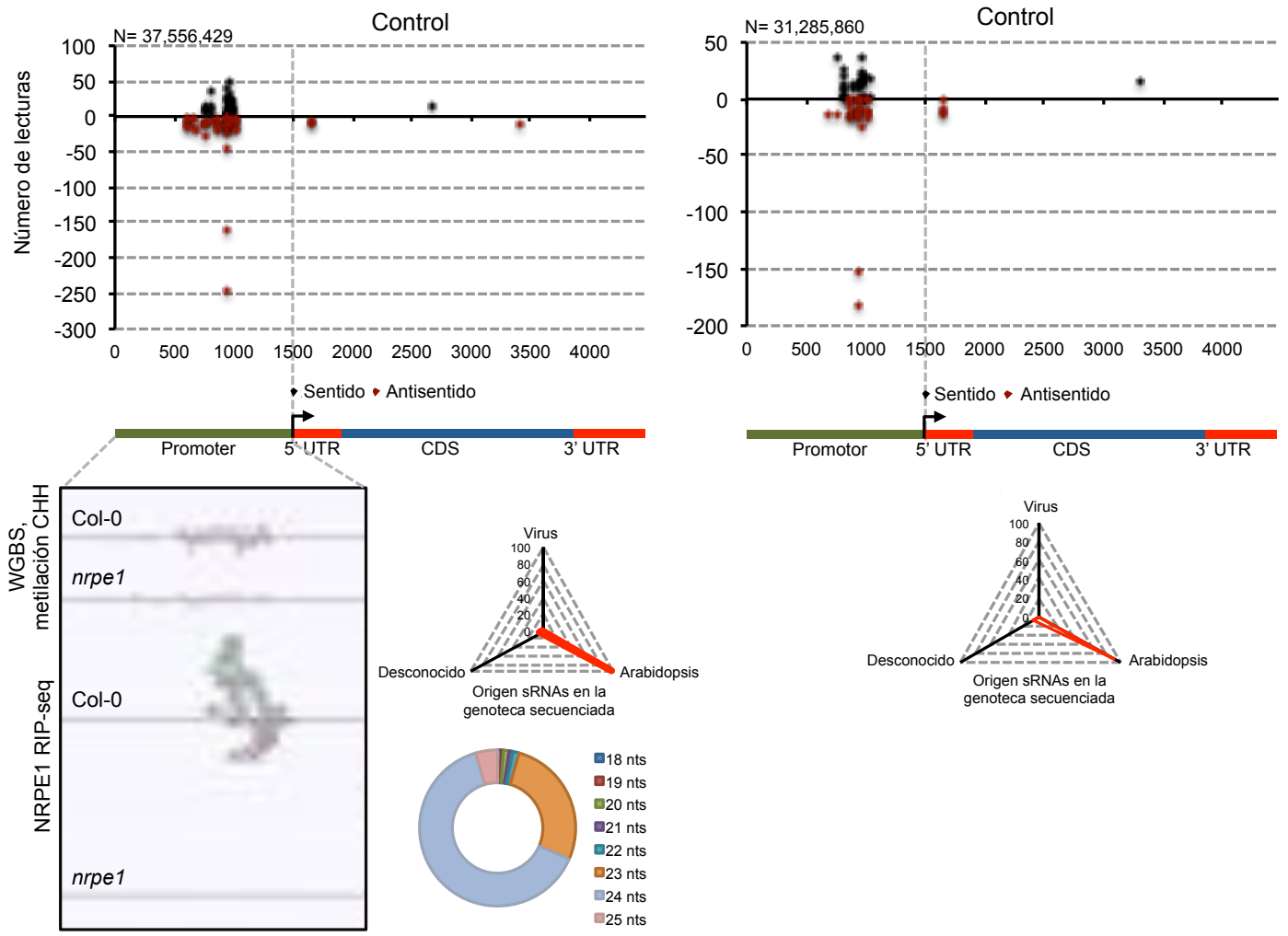

Figura 3.11. Distribución de siRNAs derivados de BIRl en hojas de roseta de Arabidopsis silvestres inoculadas con extracto de planta sana. Los siRNA sentido (puntos negros) y antisentido (puntos rojos) están representados como valores positivos y negativos respectivamente en el eje Y. El gráfico triangular representa la proporción de pequeños RNAs de diferentes orígenes en el total secuenciado. $\mathrm{N}$ es el número total de lecturas en la secuenciación. El gráfico circular representa la distribución por tamaños de los siRNAs derivados de BIRl. La porción rectangular representa el estado de metilación asimétrica $(\mathrm{CHH})$ en el promotor de BIRl empleando datos de WGBS en Arabidopsis silvestres (Col-0) y en el mutante nrpel (Bohmdorfer et al., 2016), así como la acumulación de transcritos dependientes de Pol V en la región promotora de BIRl mediante inmunoprecipitación de RNA con un anticuerpo anti-NRPE1 seguida de secuenciación (POL V RIP-Seq) en el mutante nrpel y en Arabidopsis silvestres (Col-0) (Bohmdorfer et al., 2016). Se muestran dos experimentos de secuenciación independientes (izquierda y derecha). 


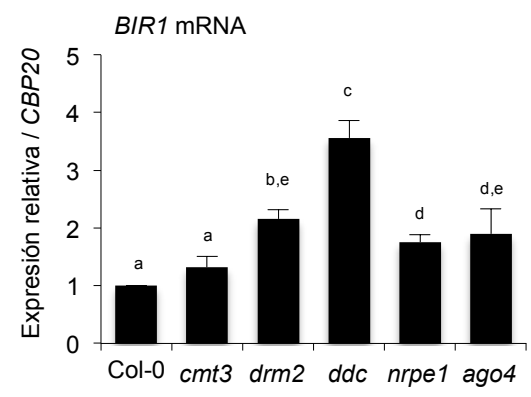

Figura 3.12. Acumulación relativa, mediante $q R T-P C R$, de transcritos de BIRl en hojas de roseta de Arabidopsis silvestres (Col-0) y mutantes RdDM (cmt3-11t, drm2-2, ddc, nrpe1 y ago4-1). Los valores se relativizaron respecto al fondo silvestre (valor 1.0) y las distintas letras indican diferencias estadísticamente significativas $(P<0,001)$.

La activación de esta ruta de silenciamiento transcripcional debería implicar la síntesis de transcritos dependiente de Pol V en la región promotora del gen diana (Matzke and Mosher, 2014). En consonancia con esta predicción, empleando una pareja de oligos aguas arriba del sitio de iniciación de la transcripción, pudimos detectar por qRT-PCR la acumulación de transcritos en la región intergénica que contiene el hipotético promotor de BIRl (Figura 3.13). Estos transcritos se acumulaban a niveles muy bajos en plantas mutantes nrpel deficientes en Pol V, lo que indica que Pol V es necesaria para su producción (Figura 3.13). La qRT-PCR también confirmó la acumulación de transcritos dependientes de Pol V en la región intergénica locus 22 (IGN22, del inglés Intergenic Region 22) que se usó como control positivo (Zhong et al., 2012) (Figura 3.13).

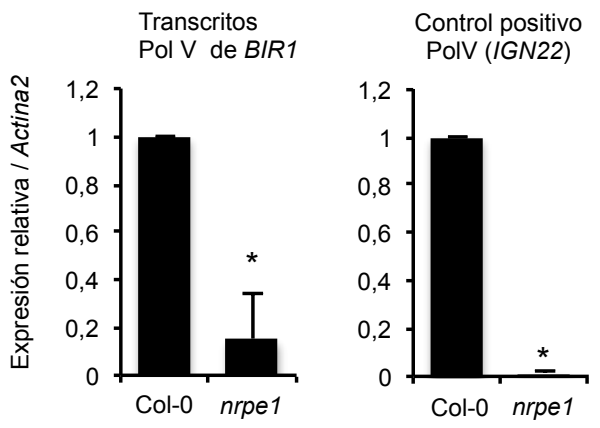

Figura 3.13. Acumulación relativa, mediante qRT-PCR, de transcritos del promotor de BIRl dependientes de Pol $\mathrm{V}$ en hojas de roseta de Arabidopsis silvestres (Col-0) y del mutante nrpe1. Los valores se relativizaron respecto al fondo silvestre (valor 1.0) y las diferencias se consideraron significativas con $P<0,001$ (*).

De acuerdo con el modelo predicho, los transcritos de la Pol V servirían como andamio para la unión de los siRNAs derivados del promotor de BIRl que guiarían los eventos de metilación de DNA de forma específica de secuencia. Si la vía RdDM metila el promotor de $B I R 1$, los niveles de metilación del DNA deberían disminuir en mutantes de RdDM. Para probarlo analizamos el estado de metilación de la región promotora de BIRl en el genotipo silvestre y en varios mutantes de metilación del DNA empleando la técnica Chop-PCR (Figura 3.14) (Bohmdorfer et al., 2014). 


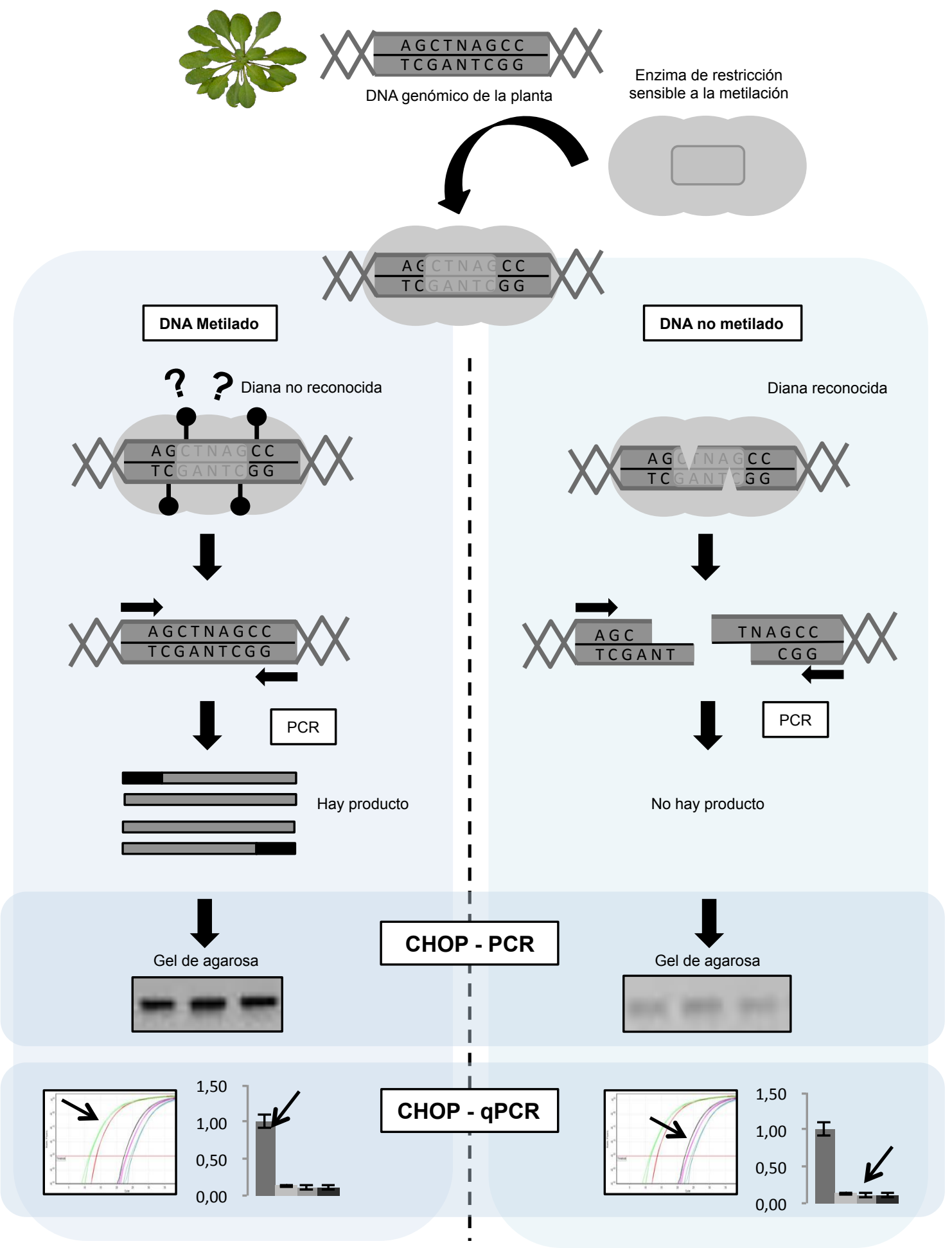

Figura 3.14. Diagrama esquemático de las técnicas de Chop-PCR y Chop-qPCR. El DNA genómico de la planta con enzimas sensibles a la metilación. Si el DNA se encuentra metilado la enzima no reconoce su secuencia de corte facilitándose la amplificación de la región analizada con cebadores flanqueantes. Por el contrario si el DNA no está metilado la enzima reconoce su diana específica y corta el DNA, impidiendo la amplificación por PCR de la región analizada. El grado de acumulación del producto amplificado refleja la frecuencia de metilación del DNA. El producto de amplificación puede visualizarse en un gel de agarosa teñido con bromuro de etidio o cuantificarse mediante Chop-qPCR con un gen endógeno normalizador. 
En nuestro ensayo digerimos el DNA genómico con las endonucleasas DdeI y NlaIII. Estas enzimas se han empleado con éxito en la evaluación de la metilación asimétrica $(\mathrm{CHH})$ en varios loci regulados vía RdDM (Bohmdorfer et al., 2014). Como control positivo para las digestiones con DdeI y NlaIII empleamos los genes At $1 g 49490$ e IGN36, respectivamente, ambos metilados vía RdDM (Bohmdorfer et al., 2014). Como control negativo se emplearon secuencias de DNA (At1g55535 and At2g36490) sin sitios de restricción para esta enzimas. Empleando cebadores específicos de la región promotora de BIRl pudimos obtener para el fondo silvestre productos de amplificación a partir de las muestras de DNA tratadas con DdeI ó NlaIII (Figura 3.15A). Este resultado indica que las citosinas en los sitios de restricción de estas enzimas estaban metiladas. Por el contrario, detectamos mucho menos producto de PCR en los mutantes nrpe1, drm2-2 y ago4-1, lo que sugiere que los transcritos de la polimerasa V, AGO4 y DRM2 son requeridos para metilar citosinas en esta región (Figura 3.15A). El mismo patrón se observó en los controles positivos (Figura 3.15A), mientras que los controles negativos produjeron bandas de amplificación en todos los fondos genéticos (Figura 3.15A). Para cuantificar las diferencias en la metilación del promotor de BIRl entre mutantes RdDM y plantas silvestres empleamos la PCR cuantitativa (qPCR) a partir de las muestras de DNA genómico digeridas con las enzimas DdeI y NlaIII (Chop-qPCR). Como control positivo cuantificamos la cantidad de producto amplificado en los genes Atlg49490 e IGN36 para las digestiones con DdeI y NlaIII respectivamente. Como control negativo empleamos los genes At3G18780 y At2G36490 que carecen de sitios de restricción para DdeI y NlaIII, respectivamente. Los resultados obtenidos confirmaron que los niveles del fragmento amplificado tanto en el promotor de BIRl como en los controles positivos empleados se redujeron de forma similar en todos los mutantes (Figura 3.15B). Por el contrario, no observamos diferencias en la acumulación de productos de PCR para las secuencias empleadas como control negativo (Figura 3.15B). Estos resultados confirman que la región promotora de BIRl se encuentra metilada por la vía RdDM. 

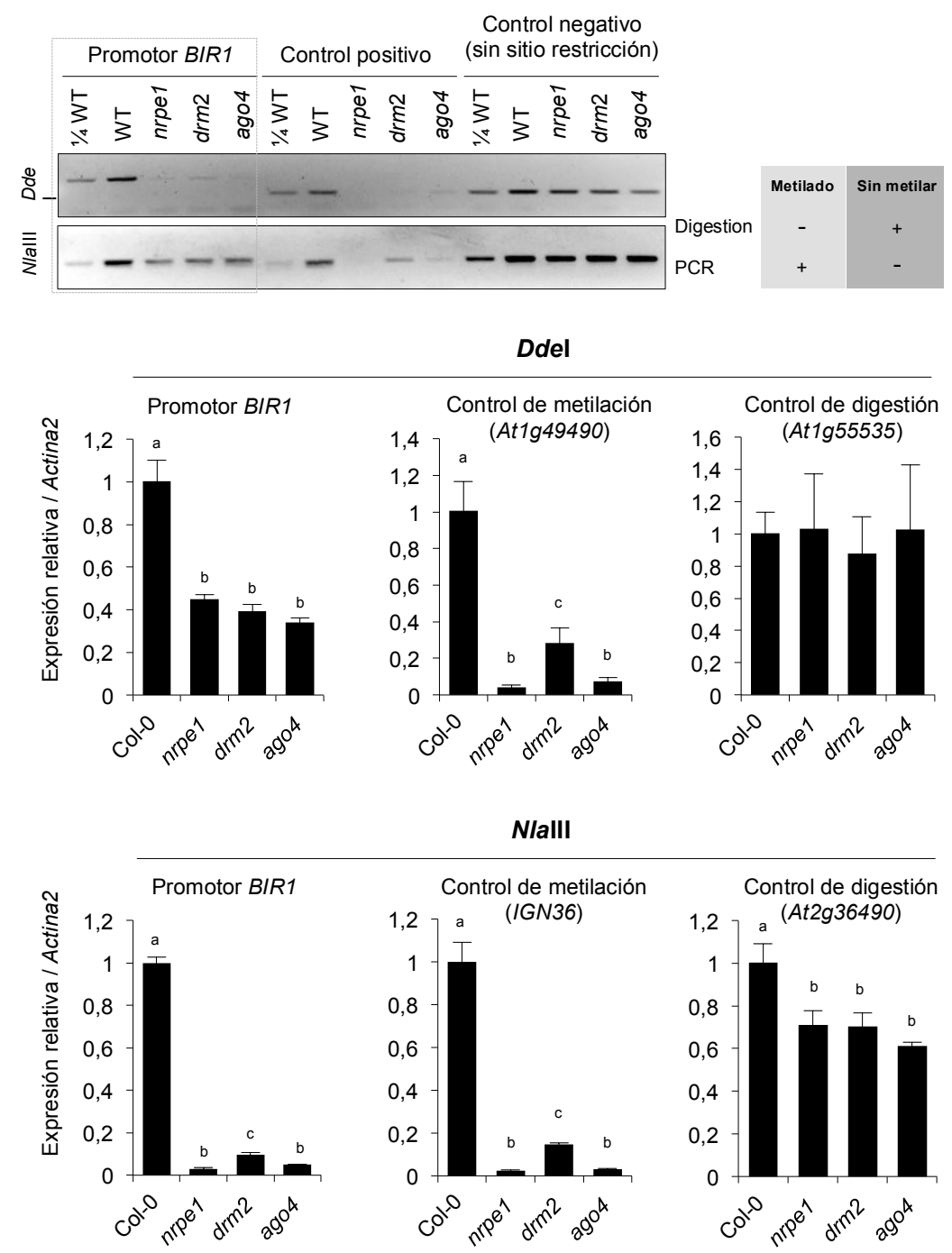

Figura 3.15. Grado de metilación de las citosinas del promotor de $B I R l$ en un contexto asimétrico $(\mathrm{CHH})$ determinado por Chop-PCR (A) y Chop-qPCR (B) en hojas de roseta de Arabidopsis silvestres (Col-0) y mutantes RdDM (nrpe1, drm2-2 y ago4-1). El DNA genómico se digirió con las enzimas sensibles a la metilación DdeI y NlaIII. La región del promotor de BIRl analizada contiene sitios de restricción para las enzimas empleadas. Como control de metilación se amplificó una secuencia metilada en $\mathrm{CHH}$ que contiene las dianas de DdeI y NlaIII. Como control negativo de digestión se amplificó una secuencia que carecía de las dianas de las enzimas usadas. El producto de amplificación de la Chop-PCR se separó en un gel de agarosa al $1 \%$ y se tiñó con bromuro de etidio. Los valores cuantificados por qPCR se relativizaron respecto al fondo silvestre Col-0 (valor 1.0). Las distintas letras indican diferencias estadísticamente significativas $(P<0,001)$.

Finalmente consultamos los patrones de metilación observados para la región promotora de BIRl en experimentos de secuenciación por bisulfito del genoma completo de Arabidopsis (WGBS, del inglés whole genome bisulfite sequencing) (datos cedidos por el Dr. Wierzbicki, University of Michigan, USA) (Wierzbicki et al., 2012). Los resultados observados muestran que la región promotora de BIRl se encontraba altamente metilada, tanto en un contexto de secuencia simétrico (CG y $\mathrm{CGH}$ ) como asimétrico (CHH) (Figura 3.16A). Así mismo, la metilación en esta región disminuía 
considerablemente en los mutantes que carecían de Pol V (nrpel) comparándola con las plantas de genotipo silvestre (Figura 3.16B). A continuación empleamos los datos de inmunoprecipitación de RNA con un anticuerpo anti-NRPE1 seguida de secuenciación (Pol V RIP-seq) descritos por G. Bohmdorfer (Bohmdorfer et al., 2016) para visualizar la presencia de RNA dependiente de Pol V en el promotor de BIRl (Figura 3.16C). En consonancia con nuestras observaciones previas (Figura 3.13), los transcritos de RNA en el promotor de BIRl desaparecían en el mutante nrpel (Figura 3.16B). En conjunto todos nuestros resultados demuestran que BIRl se encuentra regulado vía RdDM en condiciones normales de crecimiento y desarrollo.
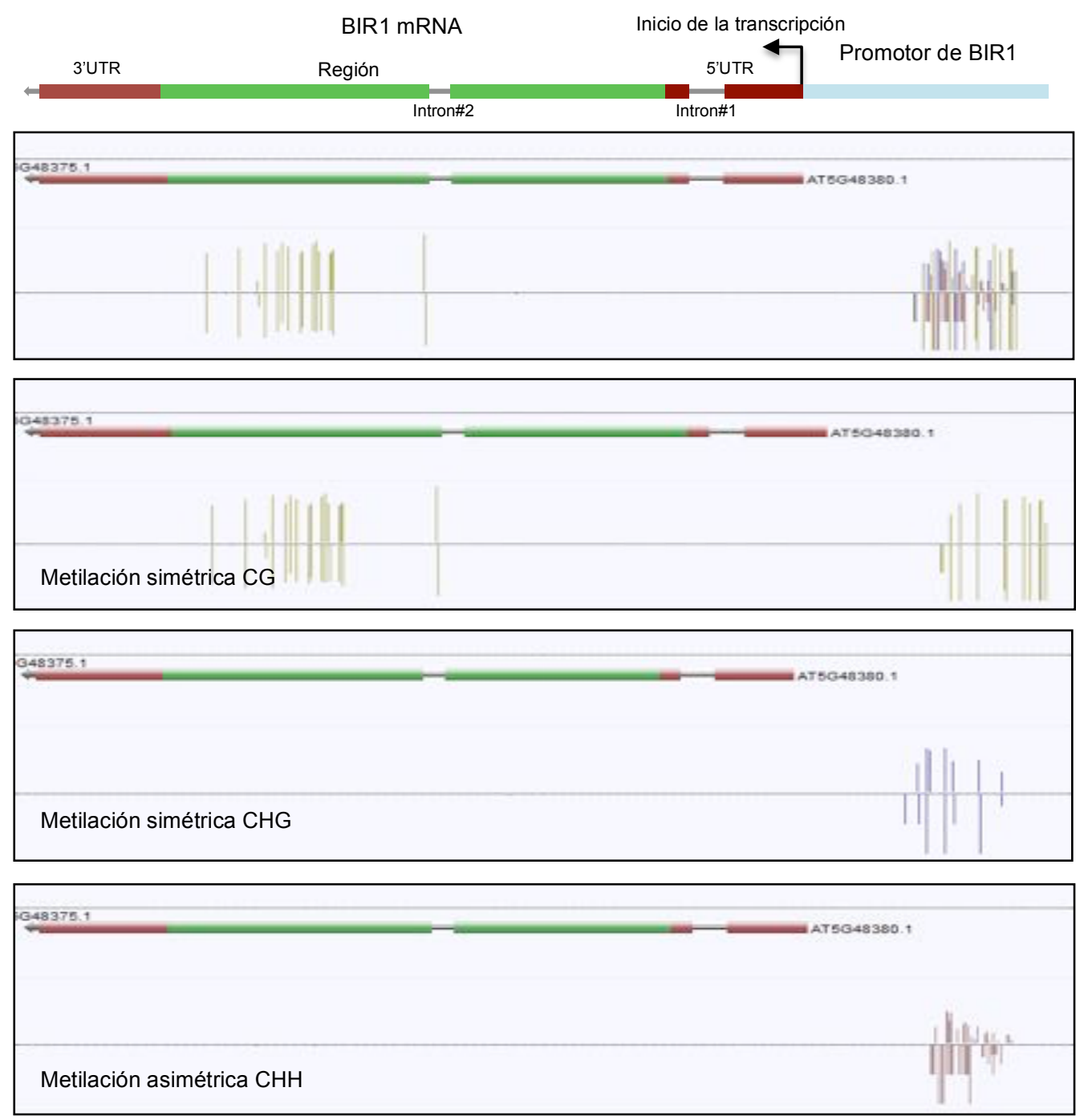

Figura 3.16. Estado de metilación del promotor de BIRl empleando datos de WGBS en Arabidopsis. Los datos de secuenciación muestran metilación simétrica (CG y $\mathrm{CHG}$ ) y asimétrica $(\mathrm{CHH})$ en el locus BIRI (Stroud et al., 2013). 


\subsubsection{Efecto de la infección en la regulación transcripcional de $B I R I$}

La alta acumulación de trascritos de $B I R 1$ en tejidos infectados podría ser consecuencia de la activación transcripcional de BIRl en respuesta al virus. Para comprobar esta posibilidad, plantas transgénicas de Arabidopsis que expresan la proteína de fusión GFP:GUS bajo el control del promotor de BIRl (ver apartado 3.3.1) se inocularon con TRV y se analizaron a los 8 dpi mediante un ensayo de tinción histoquímica X-gluc. Este ensayo detectó actividad GUS (ß-glucoronidasa) de forma reproducible en las hojas de la roseta y tejidos aéreos de las plantas transgénicas tras la infección con TRV (Figura 3.17A). El patrón ubicuo de distribución espacial contrastaba con lo observado en plantas control inoculadas con extractos de planta sana (Figura 3.17A). Empleando un ensayo Northern blot con una sonda radiactiva específica de la secuencia GFP detectamos niveles de acumulación del gen delator mucho más altos en plantas infectadas que en los correspondientes controles no infectados (Figura 3.17B) Estos resultados demuestran que el promotor de BIRl se activa transcripcionalmente en todos los tejidos de la planta durante la infección por TRV.

A

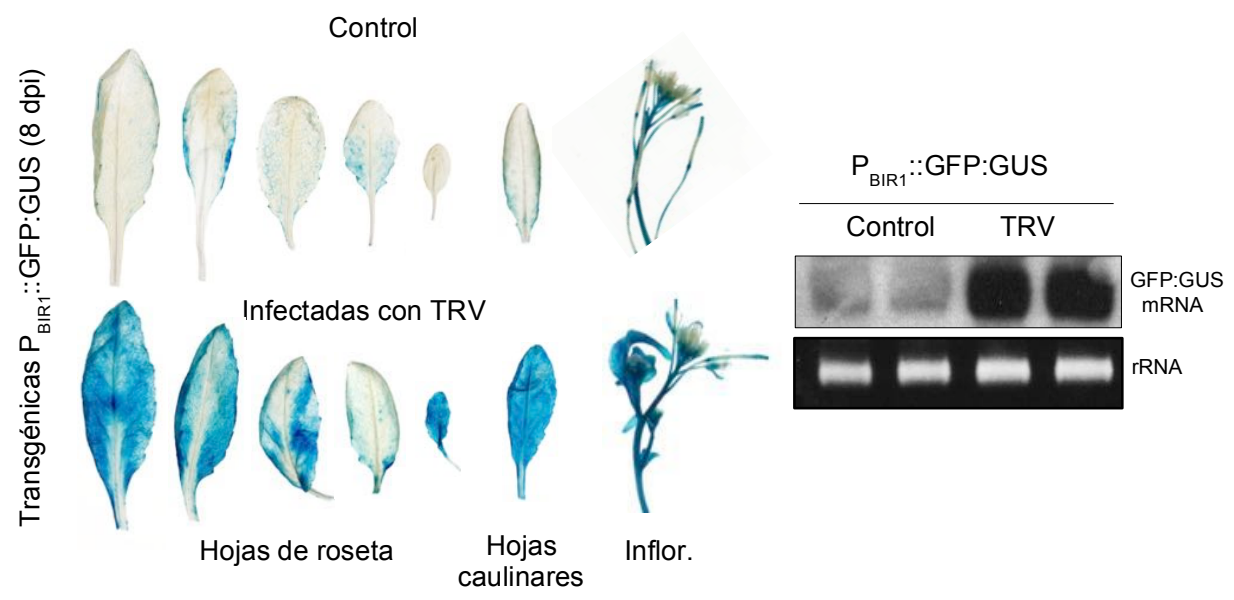

Figura 3.17. A) Localización histoquímica de la expresión de $G U S$ en plantas de Arabidopsis $\mathrm{P}_{\mathrm{BIR} 1}:$ GFP:GUS transgénicas inoculadas con TRV y con extracto de planta sana (control) a los 8 dpi. B) Determinación, mediante Northern blot, de los niveles de transcrito GFP:GUS. Para detectar el transcrito se empleó una sonda marcada radioactivamente específica de GFP.

A continuación nos preguntamos si la inducción transcripcional de BIRl durante la infección podría deberse a cambios en el estatus de metilación de su promotor. Cuando analizamos la acumulación de pequeños RNAs aguas arriba del sitio de inicio de la transcripción de BIRl en las plantas infectadas con TRV y con TuMV observamos cantidades equiparables a los obtenidos con los controles inoculados con extracto de planta sana (Figura 3.18). Esto sugería que la infección del virus no comprometía el 
silenciamiento transcripcional de BIRl. Para confirmarlo comparamos los niveles de metilación de la región promotora de BIRl en plantas infectadas con TRV y en plantas control no infectadas mediante Chop-qPCR. Nuestros resultados mostraron niveles similares de metilación asimétrica $(\mathrm{CHH})$ en el promotor de BIRl entre plantas infectadas con TRV y plantas control tras la digestión con la enzima NlaIII (Figura 3.19A). Por el contrario, los niveles relativos de DNA amplificado fueron ligeramente menores en las muestras infectadas que en las plantas sin infectar en las digestiones con DdeI, probablemente debido a la actividad estrella de la enzima (Figura 3.19A). Al comparar plantas infectadas con TRV y plantas control no detectamos cambios significativos en la metilación CHH de las dianas IGN36 y Atlg49490, utilizadas como controles de metilación (Figura 3.19A). Para corroborar que la digestión se había llevado a cabo eficazmente se incluyó un control positivo de Chop-PCR y se amplificó el gen AGO4 que contiene las dianas DdeI y NlaIII sin metilar (Figura 3.19B). Finalmente medimos la acumulación de transcritos de BIRl mediante qRT-PCR en mutantes deficientes en RdDM inoculados con TRV o con extracto de planta sana. Los resultados obtenidos demuestran que BIRl se inducía de forma similar en presencia de TRV tanto en el fondo silvestre como en cada uno de los fondos mutantes analizados (excepto drm2-2), lo que indica que TRV promueve la transcripción de BIRl independientemente de su estado de metilación (Figura 3.20).
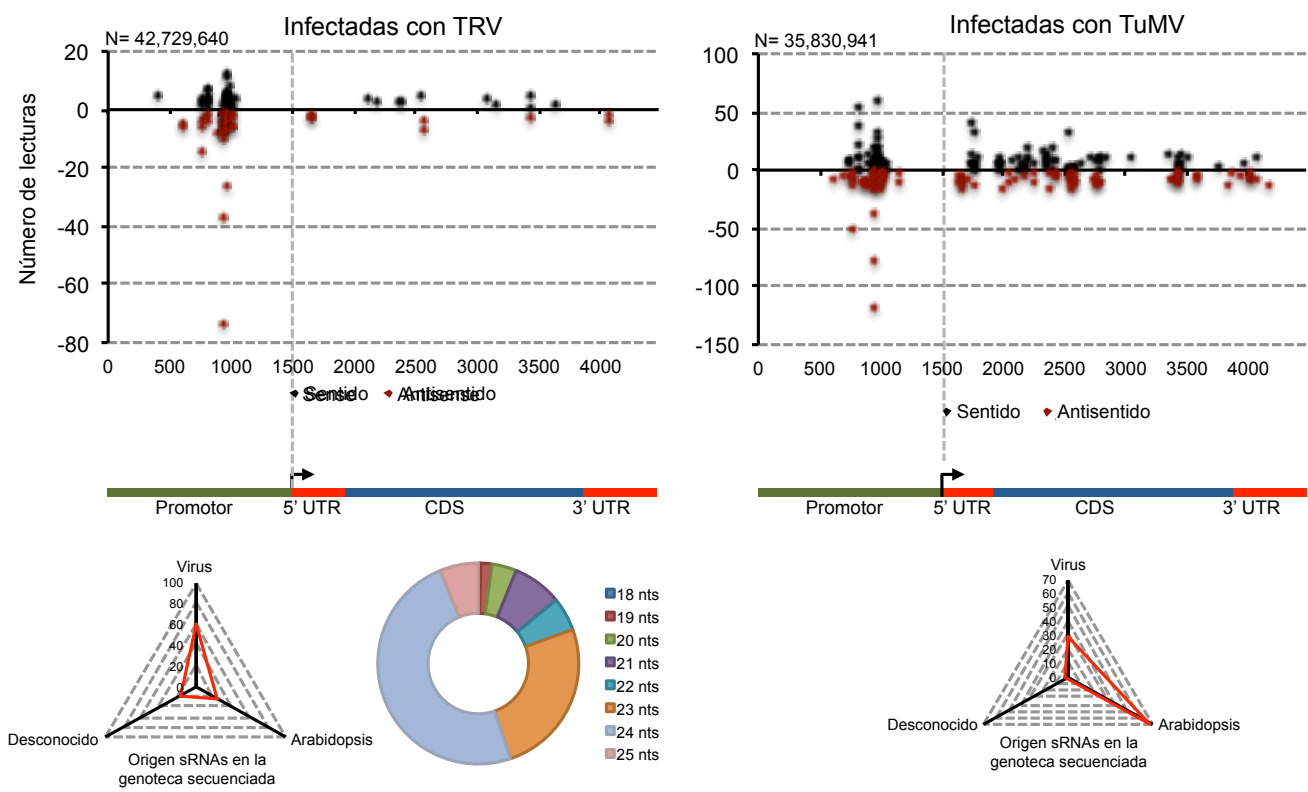

Figura 3.18. Distribución de siRNA derivados de BIRl en hojas de roseta de Arabidopsis silvestres infectadas con TRV (izquierda) y TuMV (derecha). Los siRNA sentido (puntos negros) y antisentido (puntos rojos) están representados como valores positivos y negativos, respectivamente, en el eje Y. El gráfico triangular representa la proporción de pequeños RNAs de diferentes orígenes en el total secuenciado. $\mathrm{N}$ es el número total de lecturas en la secuenciación. El gráfico circular representa la distribución por tamaños de los siRNAs derivados de BIRl. 

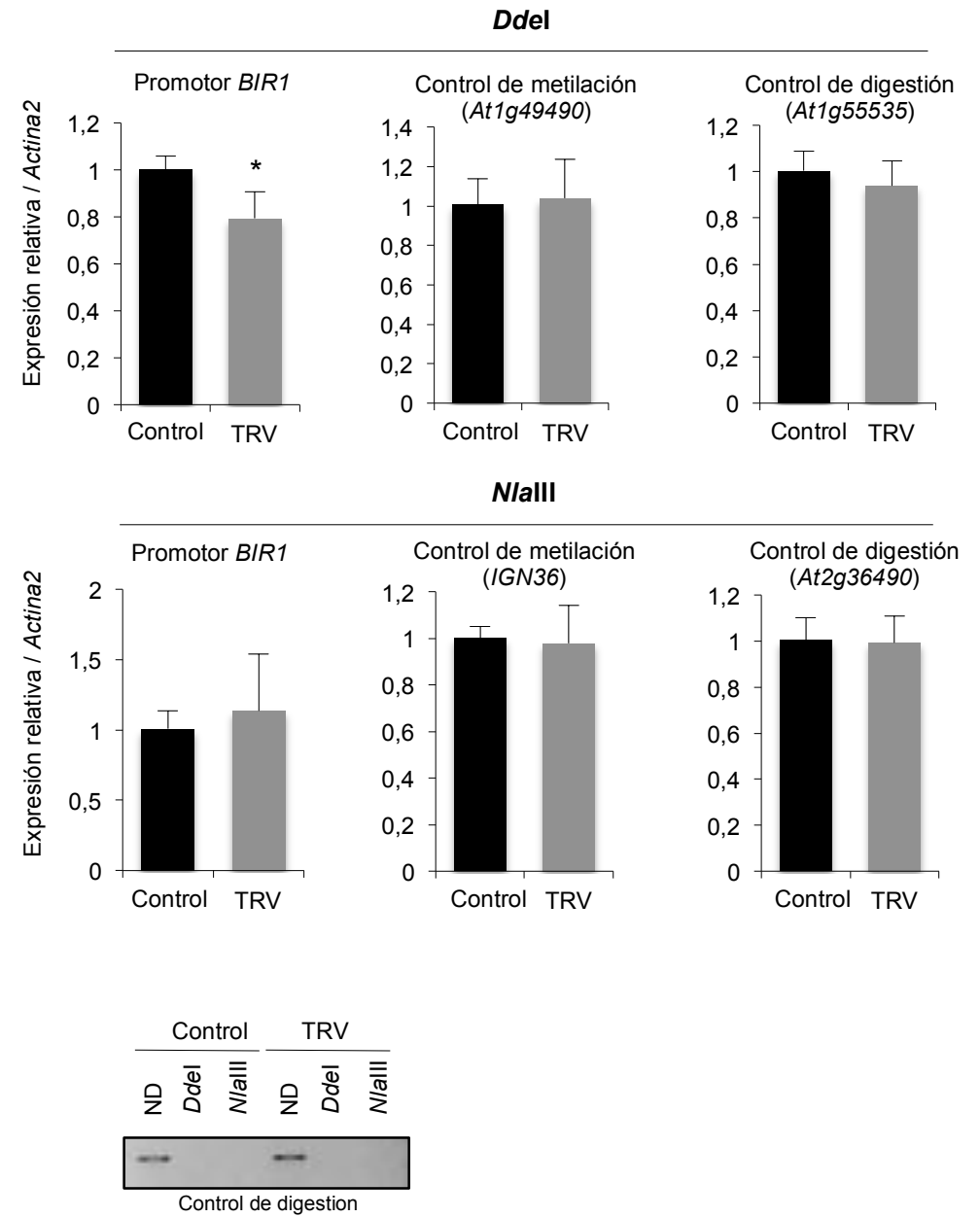

Figura 3.19. A) Grado de metilación de las citosinas del promotor de $B I R l$ en contexto asimétrico $(\mathrm{CHH})$, determinado por Chop-qPCR, en hojas de roseta de Arabidopsis silvestres inoculadas con TRV o con extracto de planta sana (control). El DNA genómico se digirió con las enzimas sensibles a la metilación DdeI y NlaIII. La región del promotor de BIRl amplificada por PCR contiene sitios de restricción para las enzimas empleadas. Como control de metilación se amplificó una secuencia metilada en CHH que contiene las dianas de DdeI y NlaIII. Como control negativo de digestión se amplificó una secuencia que carecía de las dianas de las enzimas usadas. Los valores cuantificados por qPCR se relativizaron respecto al tratamiento control. Las diferencias con los valores silvestres se consideraron significativas con $P<0,001(*)$. B) Amplificación del gen AGO4 que contiene las dianas DdeI y NlaIII sin metilar (control de digestión positivo). El producto de amplificación de la Chop-PCR se separó en un gel de agarosa al $1 \%$ y se tiñó con bromuro de etidio.

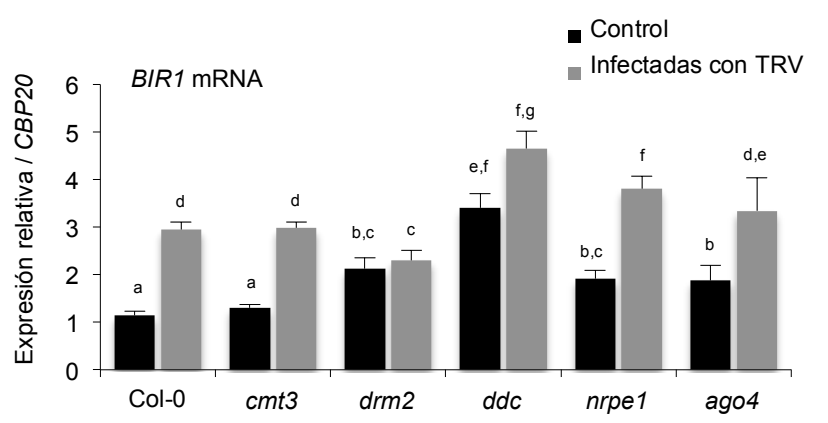

Figura 3.20. Acumulación relativa, mediante qRT-PCR, de transcritos de BIRl en hoja de roseta de Arabidopsis silvestres (Col-0) y mutantes RdDM (cmt3-11t, drm2-2, ddc, nrpe1 y ago4-1) inoculados con TRV o con extracto de planta sana (control). Los valores se relativizaron respecto al fondo silvestre Col-0 inoculado con extracto de planta sana (valor 1.0). Las distintas letras indican diferencias estadísticamente significativas, $P<0,05)$. 
Finalmente, llevamos a cabo un experimento de secuenciación por bisulfito específica de locus para analizar la frecuencia de metilación de cada citosina en el promotor de BIR1. Para ello realizamos una reacción de conversión C-T por tratamiento con bisulfito sódico (DNA methylation Gold-Kit, Zymoresearch) (He et al., 2009) empleando DNA genómico de Arabidopsis silvestre no inoculada (sanas), inoculada con extracto de planta sana o infectada con TRV. Para optimizar las condiciones del ensayo, el perfil de metilación de la región promotora se determinó a partir de dos reacciones de PCR que abarcaban la región metilada observada según los datos de WGBS descritos en el apartado anterior. Como control de la efectividad de la reacción de conversión C-T se amplificó una secuencia de Arabidopsis que carecía de metilación (entre las coordenadas 19,573,407 y 19,573,671 en el cromosoma 4). Los fragmentos amplificados se clonaron en un plásmido TOPO-TA (Invitrogen) y se secuenciaron al menos 30 clones por cada construcción. La comparación de las secuencias entre las muestras analizadas no evidenció cambios significativos en la frecuencia de metilación en ninguno de los tres posibles contextos dentro de la región promotora de BIRl (Figura 3.21) corroborando así las observaciones anteriores. La conversión C-T del fragmento no metilado empleado como control fue total en todos los clones secuenciados, indicando que la reacción de conversión C-T del bisulfito ocurrió eficazmente. En conjunto podemos concluir que la infección por TRV promueve eficientemente la transcripción de BIRl sin interferir con su silenciamiento epigenético en Arabidopsis. 

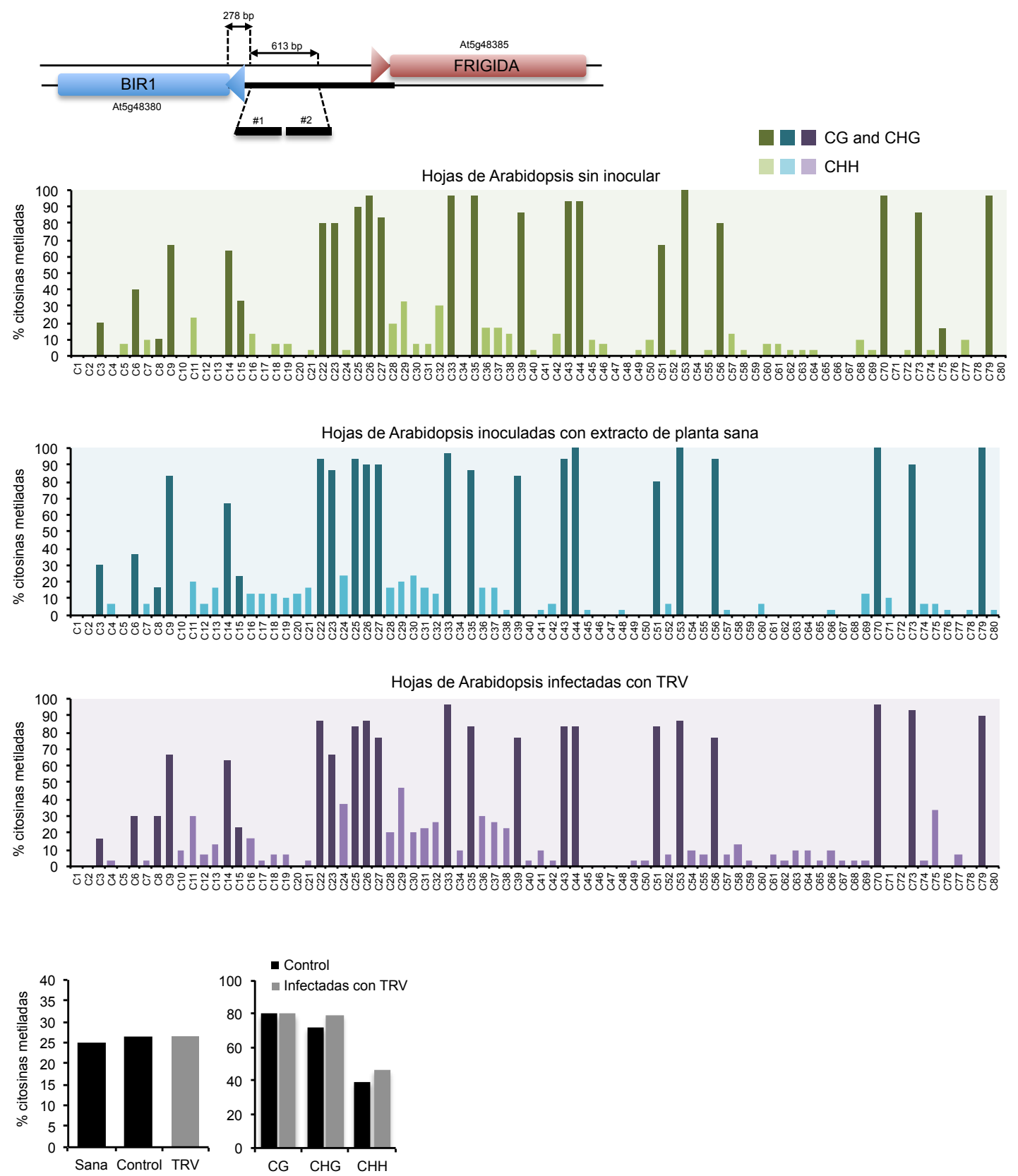

Figura 3.21 Estado de metilación del promotor de BIRl usando secuenciación por bisulfito específica de gen (arriba) y proporción del total de citosinas metiladas (abajo izquierda) y de la metilación en los contextos $\mathrm{CG}, \mathrm{CHG}$ y $\mathrm{CHH}$ (abajo derecha). Se analizaron muestras no inoculadas (sanas), inoculadas con extracto de planta sana (control) e inoculadas con TRV. H representa A, T o C.

\subsubsection{Efecto de SA sobre el patrón de metilación en el promotor de BIR1}

A continuación investigamos si la inducción transcripcional de $B I R 1$ mediada por SA podría asociarse con cambios en el estatus de metilación de su secuencia promotora. Para comprobarlo analizamos el efecto de SA sobre la acumulación de transcritos de $B I R 1$ en diversos mutantes defectivos para RdDM en los que el promotor de BIRI está hipometilado. Los resultados obtenidos por qRT-PCR demostraban que BIRl se induce 
gradualmente a 6 y $12 \mathrm{~h}$ tras la aplicación del $\mathrm{SA}$ en todos los fondos genéticos analizados (Figura 3.22).
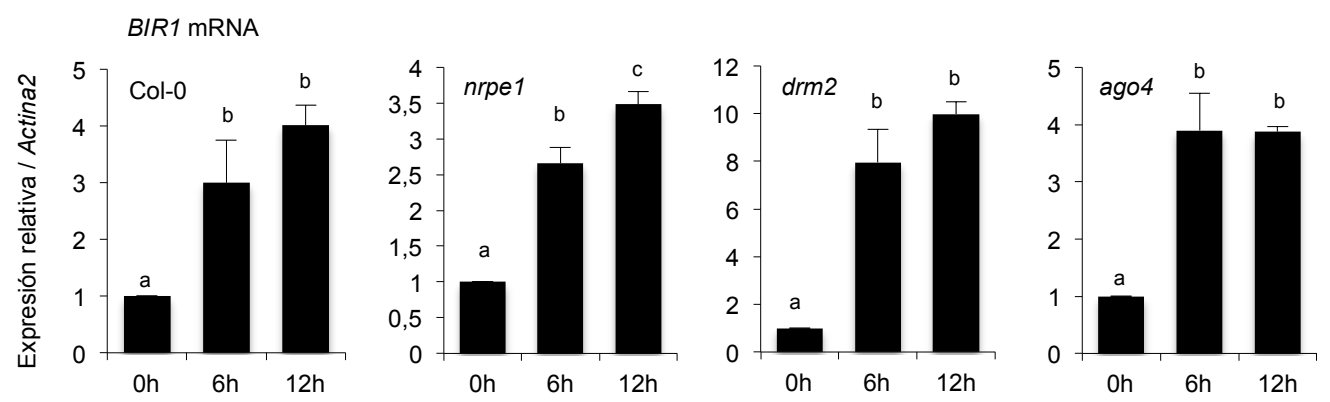

Figura 3.22. Acumulación relativa, mediante $\mathrm{qRT}-\mathrm{PCR}$, de transcritos de $B I R 1$ en hoja de roseta de Arabidopsis silvestres (Col-0) y mutantes RdDM (cmt3-11t, drm2-2, ddc, nrpel y ago4-1) a las 0, 6 y 12 $\mathrm{h}$ de ser pulverizados con SA. Los valores se relativizaron respecto al tratamiento en tiempo 0 (valor 1.0). Las distintas letras indican diferencias estadísticamente significativas $(P<0,001)$.

De estas observaciones se desprende que la activación de $B I R I$ en respuesta al SA es ajena al estado de metilación de su promotor. Para confirmarlo, realizamos experimentos de Chop-PCR como los descritos en el apartado 3.3.1 empleando las enzimas sensibles a la metilación asimétrica DdeI y NlaIII. Los resultados obtenidos muestran una menor amplificación de la región promotora en los mutantes nrpe1, drm22 y ago4-1 respecto a las plantas silvestres independientemente del tratamiento con SA, lo que sugiere que los niveles de metilación del promotor de BIRl no se alteran tras el tratamiento con la hormona (Figura 3.23A). Del mismo modo los niveles de metilación de los loci IGN36 y AtIg49490 empleados como controles para las enzimas NlaIII y DdeI, respectivamente, aparecían reducidos de forma similar en los fondos genéticos mutantes tanto en plantas control no tratadas como en plantas pulverizadas con SA (Figura 3.23A). Por el contrario los loci que carecían de sitios de restricción (Atlg55535 y At2g36490) amplificaban de forma similar en todos los tratamientos y fondos genéticos (Figura 3.23A). A continuación cuantificamos los niveles de metilación del promotor BIRl mediante el método de Chop-qPCR. Los resultados del ensayo confirman que la disminución en la metilación del promotor BIRl y de los loci empleados como controles de metilación en los mutantes RdDM analizados no difería entre plantas tratadas con SA y plantas no tratadas (Figura 3.23B). Finalmente analizamos por qRT-PCR la acumulación de transcritos dependientes de Pol V a partir de la región promotora de BIRl. Los resultados del experimento confirman que el tratamiento con SA no compromete la actividad Pol V para la formación de transcritos en esta región (Figura 3.24). En conjunto nuestros resultados indican que el mecanismo por el cual el SA induce la transcripción de BIRl no implica cambios en el control epigenético de su promotor. 
A

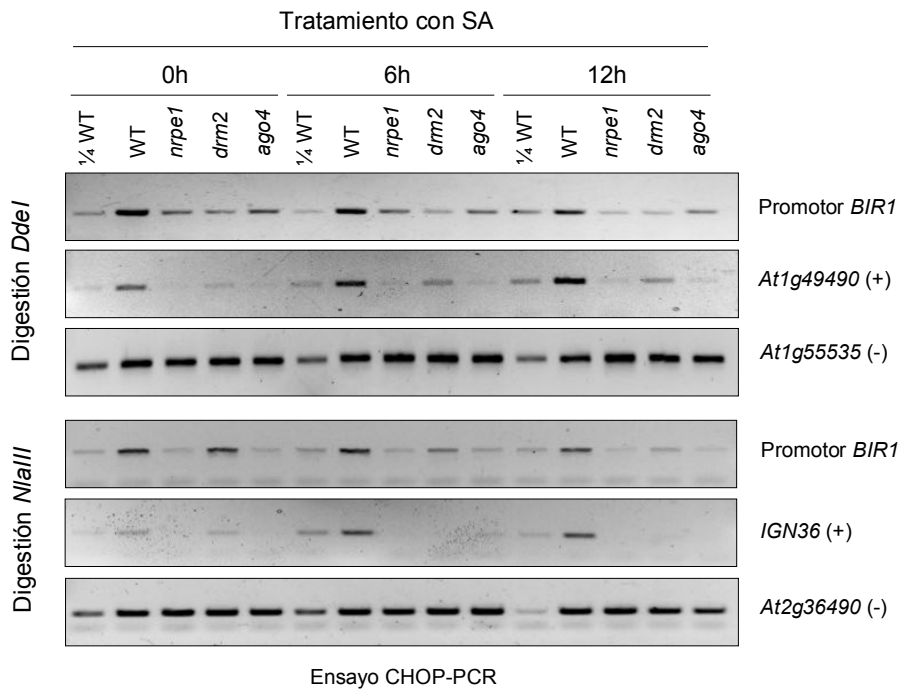

B
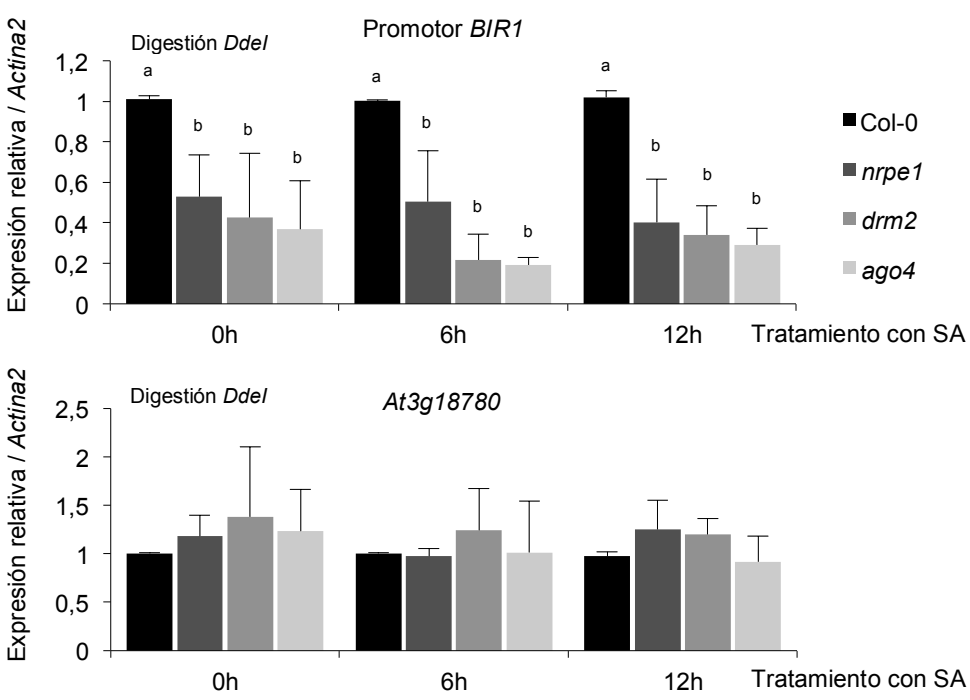

Figura 3.23. Grado de metilación de las citosinas del promotor de BIRl en contexto asimétrico $(\mathrm{CHH})$ determinado por Chop-PCR (A) y Chop-qPCR (B) en hojas de roseta de Arabidopsis silvestres (Col$0) \mathrm{y}$ mutantes $\mathrm{RdDM}$ (nrpel, drm2-2 y ago4-1) a 0,6 y $12 \mathrm{~h}$ tras el tratamiento con SA. El DNA genómico se digirió con las enzimas sensibles a la metilación DdeI y NlaIII. La región del promotor de BIRI amplificada por PCR contiene sitios de restricción para las enzimas empleadas. Como control negativo de digestión se amplificó una secuencia que carecía de las dianas de restricción analizadas. El producto de amplificación de la Chop-PCR se separó en un gel de agarosa al $1 \%$ y se tiñó con bromuro de etidio. Los valores cuantificados por qPCR se relativizaron respecto al fondo Col-0 (valor 1.0). Las distintas letras indican diferencias estadísticamente significativas $(P<0,001)$.

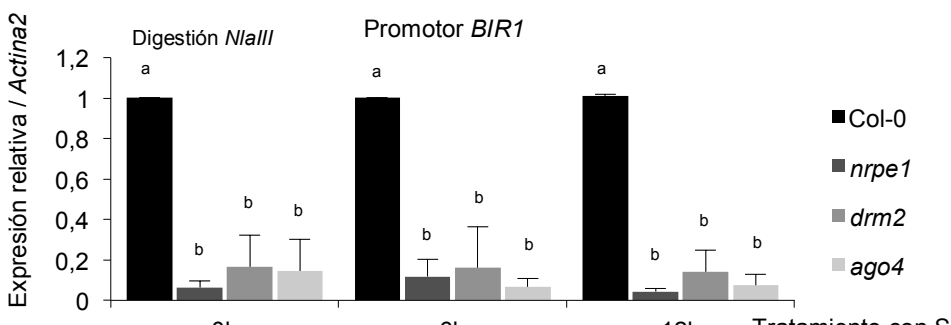

Oh

$6 h$

12h Tratamiento con SA

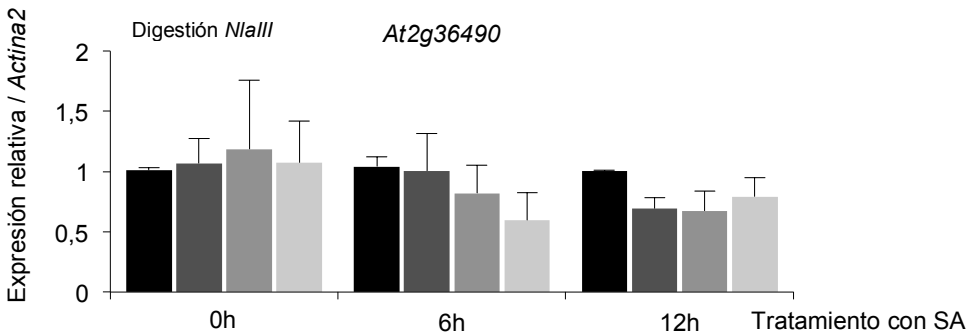




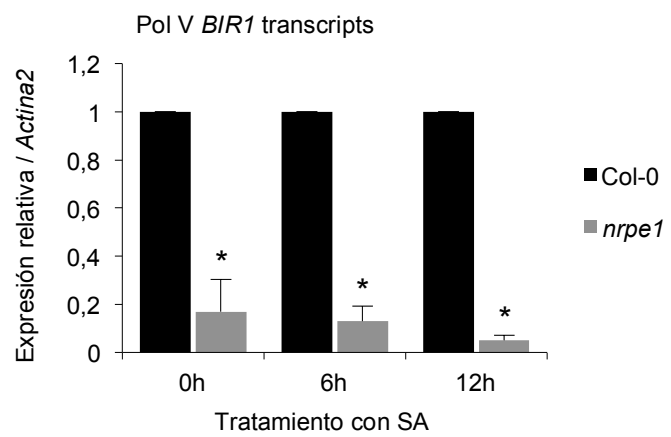

Figura 3.24. Acumulación relativa, mediante qRT-PCR, de los transcritos del promotor de BIRl dependientes de Pol $\mathrm{V}$ en hojas de roseta de Arabidopsis silvestres (Col-0) y mutantes nrpel a las 0,6 y $12 \mathrm{~h}$ tras el tratamiento con SA. Los valores se relativizaron respecto al fondo silvestre (valor 1.0) y las diferencias se consideraron significativas con $P<0,001$ (*).

\subsection{Regulación post-transcripcional de BIR1}

\subsubsection{Análisis del patrón de degradación del RNA mensajero de BIRI durante la infección por TRV}

La inducción de BIRl en respuesta a la infección viral contrasta con los resultados obtenidos en los experimentos de hibridación de micromatrices a partir de genotecas de "procesoma" que identificaban BIRl como una potencial diana de silenciamiento por RNA durante la infección. Para corroborar esta información, determinamos los sitios específicos de degradación del RNA mensajero de BIR1 mediante ultrasecuenciación del degradoma en Arabidopsis. Para nuestro experimento se prepararon genotecas de productos de degradación de RNA a partir de muestras de hojas y de inflorescencias infectadas con TRV o inoculadas con extracto de planta sana (German et al., 2009). Las lecturas obtenidas para $B I R I$ se representaron en un gráfico en el que el eje $\mathrm{Y}$ indica la abundancia de cada lectura y el eje X la longitud en nucleótidos del transcrito de BIRl, incluyendo sus regiones no codificadoras en 5' (5' UTR) y 3' (3' UTR). Cada lectura se ubica en el gráfico por la posición de su extremo 5' que es el que define el sitio de corte correspondiente al producto de degradación secuenciado. Los resultados obtenidos para BIR1 muestran la acumulación masiva de lecturas en las posiciones nucleotídicas 156, 2219 y 2247, a las que nos referiremos de ahora en adelante como A, B y C respectivamente (Figura 3.25). Por su abundancia, estas secuencias representan sitios prominentes de corte en los transcritos de BIRl que se diferencian claramente de un fondo de lecturas en otras posiciones, poco abundantes, que representan subproductos aleatorios de degradación de RNA (Figura 3.25). El hipotético punto de corte A se encontró en gran abundancia en las genotecas de degradoma preparadas a partir de plantas infectadas tanto en hojas como en inflorescencias. Aunque esta secuencia de corte no se halló en los controles inoculados con planta sana, sí se identificaron lecturas en nucleótidos cercanos, lo que sugiere que esta región resulta especialmente propensa a la degradación por RNA (Figura 3.25). Dichas lecturas se localizan en el contexto de un triplete TCA altamente repetitivo dentro de la región 5' UTR de BIRl (Figura 3.25). Por otra parte, un experimento de RLM-RACE específico de gen identificó un cuarto 
producto de corte en la posición 1817 al que nos hemos referido como D (Figura 3.25). En virtud de estas observaciones, confirmamos que los transcritos de BIRl estaban sujetos a degradación selectiva durante la infección por virus e identificamos los sitios A, B, C y D como puntos preferentes de degradación (Figura 3.26).

A
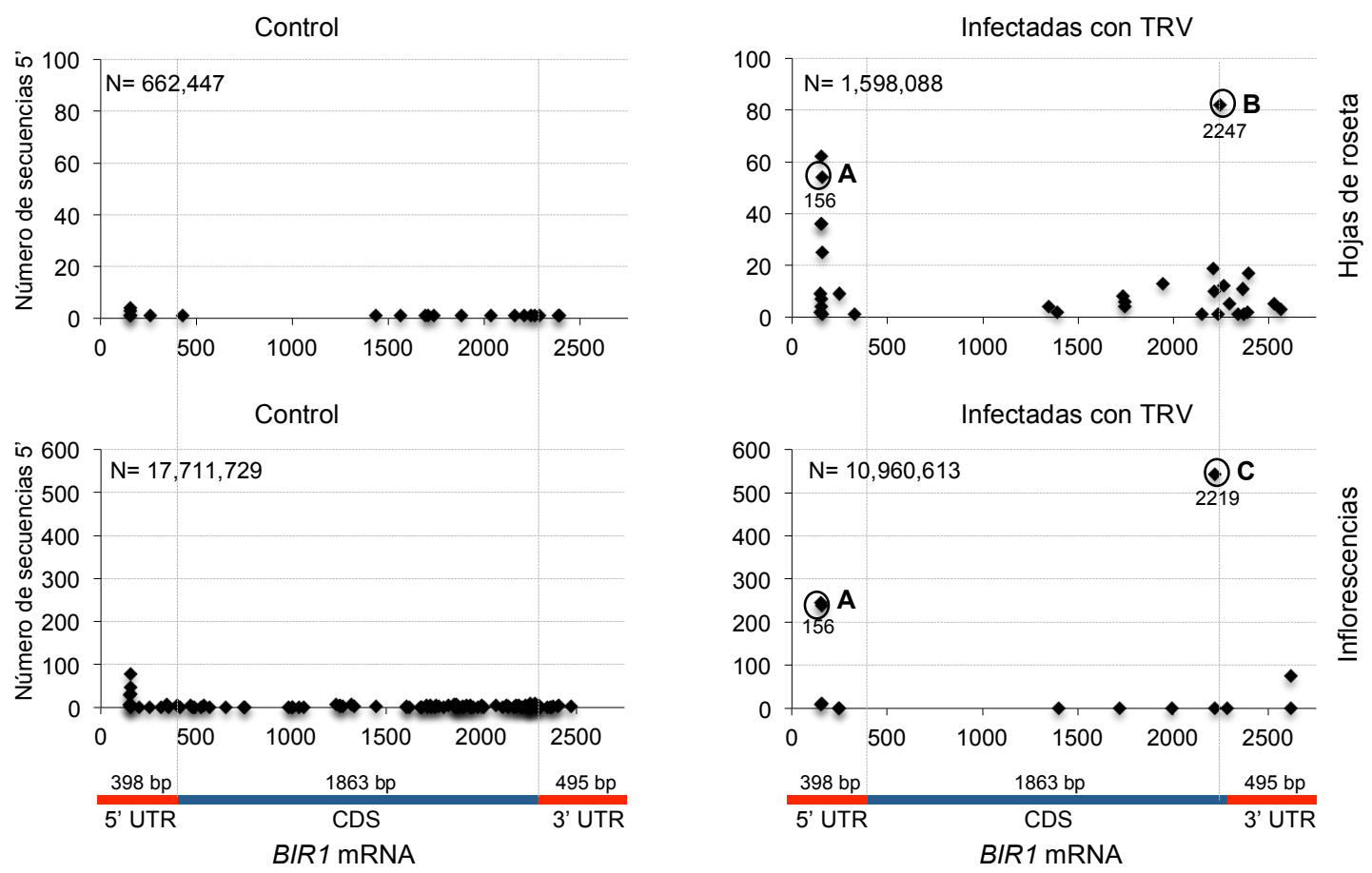

B

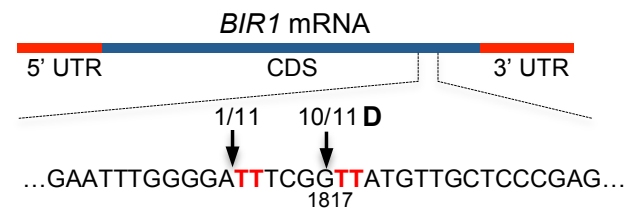

Figura 3.25. Identificación de puntos de corte preferentes en el transcrito de BIRI mediante análisis PARE en Arabidopsis inoculadas con TRV y extracto de planta sana (control). A) Puntos de corte identificados por secuenciación de degradoma. Los círculos representan las secuencias de corte más abundantes para BIRI (denominadas A, B y C) en plantas infectadas con TRV respecto al control. Se analizaron hojas de roseta e inflorescencia. $\mathrm{N}$ es el número total de lecturas secuenciadas del ensayo. B) Puntos de corte del transcrito de BIRl identificados mediante $5^{\prime}$ RACE en plantas infectadas con TRV. Se muestra la frecuencia de corte en cada posición respecto al total de clones analizados. El punto de corte más frecuente se ha denominado D. No se detectaron productos de amplificación en los controles no infectados.

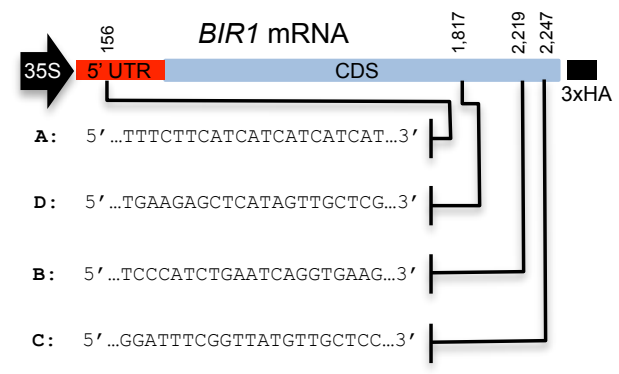

Figura 3.26. Diagrama esquemático de la posición de los puntos de corte predichos en el transcrito de BIRI denominados A, B, C y D. 


\subsubsection{Análisis mutagénico de las secuencias de corte y de su efecto sobre la expresión de BIR1 en un sistema heterólogo}

Para determinar si los puntos de corte predichos anteriormente son críticos para la regulación del RNA mensajero de $B I R l$, construimos una serie de versiones del gen $B I R 1$ en las que introdujimos sustituciones de nucleótidos que alteraban la secuencia original en cada uno de los sitios descritos pero no la secuencia aminoacídica de la proteína BIR1 (Figura 3.27A). Las construcciones generadas incluían mutaciones individuales para cada uno de los sitios identificados $(\mathrm{mA}, \mathrm{mB}, \mathrm{mC}$ o $\mathrm{mD}$ ) o combinaciones de ellas $(\mathrm{mCmD}$ o $\mathrm{mBmCmD})$. Las construcciones resultantes contenían, bajo el promotor $35 \mathrm{~S}$, la secuencia codificadora de $B I R 1$ con la región 5' UTR en su extremo 5' terminal y la secuencia del epítopo HA en su extremo 3' terminal (Figura 3.27A). Dichas construcciones se emplearon en ensayos de expresión transitoria en $N$. benthamiana mediada por Agrobacterium tumefaciens con el fin de comparar la acumulación de RNA mensajero y proteína entre la forma nativa del gen y cada uno de los mutantes. Mediante ensayos Northern blot empleando una sonda radiactiva específica de BIRl pudimos detectar cantidades equiparables de cada unos de los mutantes individuales y el gen silvestre en muestras analizadas a 1, 2 y 3 días postinfiltración (Figura 3.27B). Por el contrario, los transcritos $\mathrm{mCmD}$ y $\mathrm{mBmCmD}$ fueron significativamente más abundantes que la forma silvestre, particularmente a 2 y 3 dpi (Figura 3.27B). La acumulación de proteína BIR1 se estimó en ensayos Werstern blot empleando anticuerpos anti-HA. El análisis densitométrico de las bandas de hibridación obtenidas en cuatro réplicas independientes nos revelaron que los productos de BIRI que contenían mutaciones individuales $(\mathrm{mA}, \mathrm{mB}, \mathrm{mC}$ y $\mathrm{mD}$ ) acumulaban en el tejido infiltrado tanto como la secuencia silvestre (Figura 3.27C). Sin embargo los derivados de BIRl que contenían mutaciones en dos o tres de las secuencias de corte simultáneamente $(\mathrm{mCmD}$ y $\mathrm{mBmCmD})$ se acumulaban a mayores niveles en las hojas infiltradas que el control (Figura 3.27C). Estos resultados indican que los cambios simultáneos en todas las secuencias diana fueron suficientes para aliviar el corte del RNA mensajero e incrementar su acumulación y la de su proteína en las condiciones ensayadas. Estos experimentos parecen por tanto sugerir que el corte específico de secuencia en las posiciones identificadas a través del análisis del degradoma es fundamental para la regulación de $B I R l$. 
A

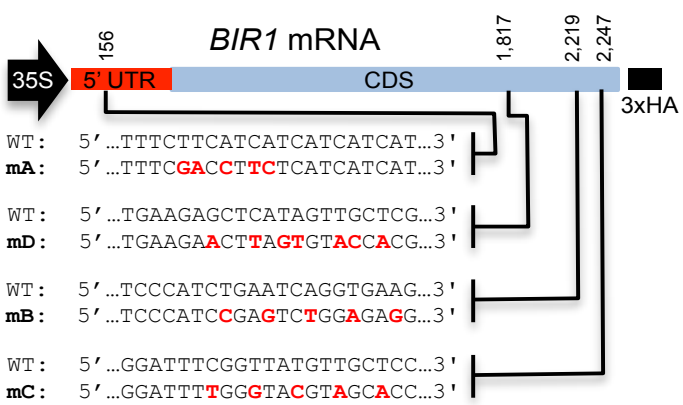

B
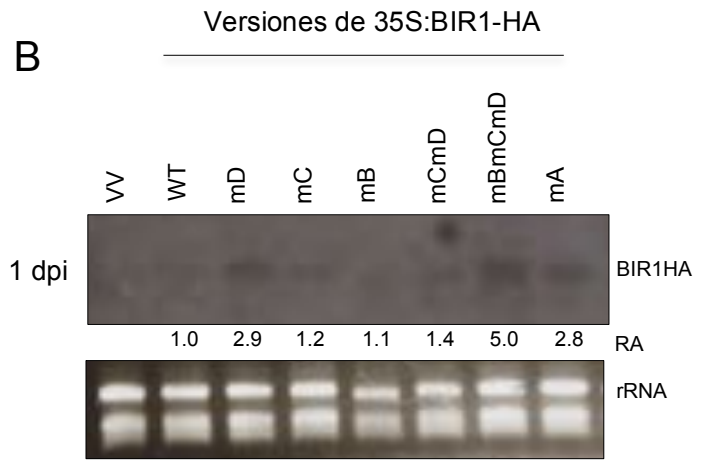

2 dpi
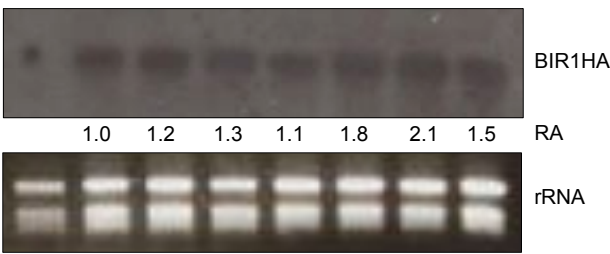

3 dpi
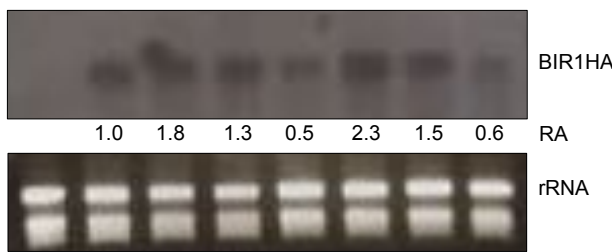

C

Acumulación relativa (\%) de proteína BIR1

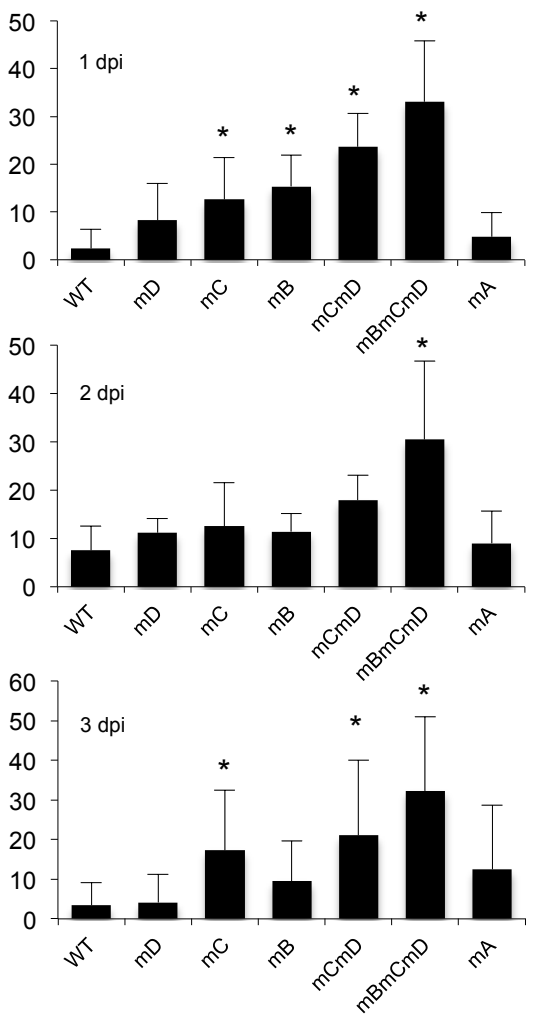

Figura 3.27. A) Representación esquemática de las construcciones empleadas para la expresión de las formas silvestre (WT) y mutantes (m) del gen BIRI bajo el promotor 35S. A, B, C y D representan los puntos de corte predichos en el análisis del degradoma. En rojo y negrita se indican las sustituciones de nucleótidos en el RNA mensajero de BIR1. B) Acumulación, mediante Northern blot, de RNA mensajero de BIRI silvestre (WT) y mutante $(\mathrm{mA}, \mathrm{mB}, \mathrm{mC}, \mathrm{mCmD}$ y $\mathrm{mBmCmD})$ en hojas agroinfiltradas con las construcciones indicadas en $\mathbf{A}$ ). Las muestras se recogieron a 1, 2 y 3 dpi y se analizaron con una sonda específica de BIR1 marcada radioactivamente. Como control se emplearon muestras infiltradas con un vector vacío $(\mathrm{VV})$. El nivel de acumulación relativa (RA) se obtuvo mediante el densitometrado de las bandas de hibridación en películas radiográficas y los valores se relativizaron respecto a la construcción silvestre (valor 1.0). C) Acumulación de proteína BIR1 silvestre (WT) y mutante (mA, mB, mC, mCmD y $\mathrm{mBmCmD}$ ), mediante análisis densitométrico de las bandas de hibridación obtenidas en un ensayo Western blot, en hojas agroinfiltradas con las construcciones indicadas en A). Las muestras se recogieron a 1, 2 y 3 dpi y las membranas se hibridaron con anticuerpo anti-HA. El gráfico muestra la intensidad media de las bandas y la SD de cinco réplicas biológicas. Las diferencias entre los valores y el control WT se consideraron significativas con $P<0,001\left(^{*}\right)$. 


\subsubsection{Caracterización del locus de MIR5658 en Arabidopsis}

Trabajos previos realizados en nuestro laboratorio con la herramienta computacional CleaveLand permitieron identificar un hipotético miRNA, ath-miR5658, como responsable potencial del corte endonucleolítico en el punto A durante la infección por TRV. La secuencia de corte correspondía precisamente con el nucleótido en posición 10 desde el extremo 5' del miRNA en la zona de apareamiento entre el miR5658 y la secuencia diana de BIR1, tal como se predice para las interacciones entre los miRNAs y sus dianas (Figura 3.28A). El análisis mediante 5'RACE de la región 5' UTR de BIRl y la secuenciación de los productos clonados correspondientes revelaron la existencia de dianas secundarias aguas abajo del sitio A dentro de esta región rica en TCA (Figura 3.28B). Curiosamente, encontramos que miR5658 mostraba cierta complementariedad en varias posiciones dentro esta región, lo cual podría explicar los cortes alternativos en las posiciones identificadas por 5'RACE (Figura 3.28B). A raíz de estos indicios diseñamos experimentos para determinar si miR5658 era un miRNA auténtico con capacidad para interaccionar funcionalmente con los transcritos de BIRl y mediar el corte específico de las secuencias dianas. 
A
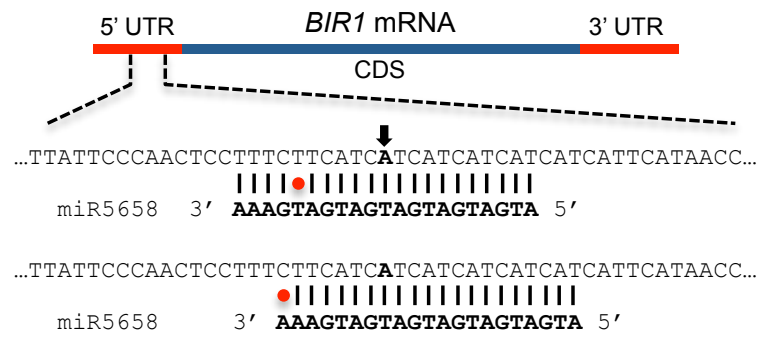
...TTATTCCCAACTCCTTTCTTCATCATCATCATCATCATCATTCATAACC.. - IIIIIIIIIIIIIIIIIIII
miR5658 3' AAAGTAGTAGTAGTAGTAGTA 5'

...TTATTCCCAACTCCTTTCTTCATCATCATCATCATCATCATTATAACC...

miR5658 3,

...TTATTCCCAACTCCTTTCTTCATCATCATCATCATCATCATCATAACC..

miR5658 3' AAAGTAGTAGTAGTAGTAGTA 5'

B

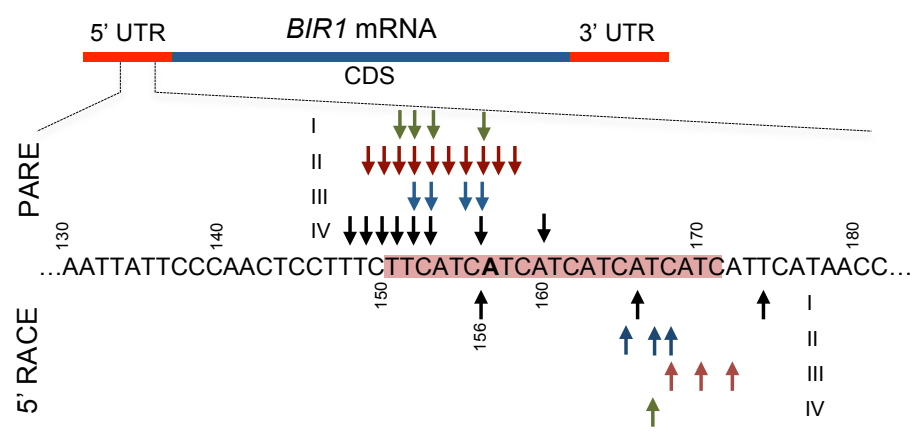

Figure 3.28. A) Esquema del apareamiento del miR5658 con la región que contiene la diana A en el transcrito de BIR1. Los puntos negros representan el apareamiento entre bases G-U mientras que los círculos rojos representan desapareamientos. La flecha indica el principal punto de corte detectado en la posición 156 por la secuenciación del degradoma. B) Esquema del mapa de corte de la región 5'UTR del RNA mensajero de BIR1. Las flechas indican los sitios de corte identificados mediante secuenciación PARE (arriba) y 5' RACE (abajo). Los números del I al IV indican las librerías del degradoma analizadas: I, hojas inoculadas control a los 14 dpi; II hojas inoculadas con TuMV a los 14 dpi; III, hojas inoculadas con TRV a los 8 dpi y IV, hojas inoculadas control a los 8 dpi.

Este supuesto miRNA deriva de un transcrito potencial con configuración antisentido (NAT) en el locus At4g39838 cuya función es desconocida. Este gen se superpone en gran parte con el gen $A t 4 g 39840$, que codifica una proteína de respuesta al estrés en la hebra opuesta (Figura 3.29). El miR5658 se identificó originalmente en plantas de Arabidopsis mediante secuenciación de la fracción de pequeños RNAs asociada a proteínas AGO y fue catalogado como miRNA en el registro de miRBase (Rajagopalan et al., 2006; Mi et al., 2008). Sin embargo, nosotros no hemos podido detectar el miR5658 en ensayos de hibridación de pequeños RNAs en plantas silvestres o en mutantes de silenciamiento de Arabidopsis empleando una sonda de oligonucleótidos complementaria al miR5658. 


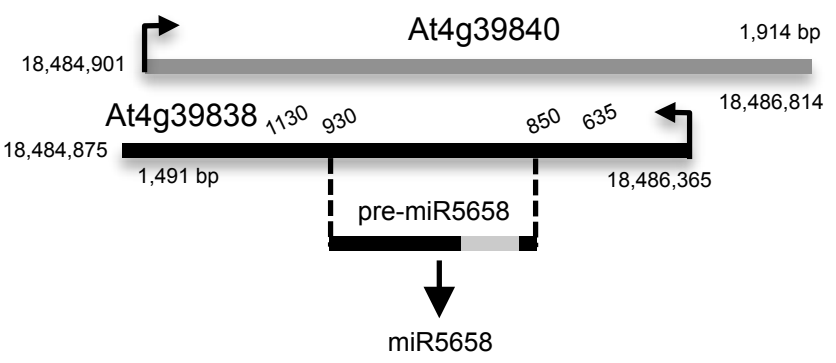

Figura 3.29. Representación esquemática del par antisentido formado por el locus At4g39838 que contiene el miR5658 y el locus At4g39840. Las flechas indican los puntos de inicio de la transcripción para ambos genes.

Tampoco fue posible identificar secuencias del miR5658 en experimentos de ultrasecuenciación de genotecas de pequeños RNAs generadas en nuestro laboratorio ni a través de la amplificación específica de amplicones de miR5658 en dichas genotecas. Si fue posible sin embargo detectar en plantas infectadas respecto a los controles inoculados con extracto de planta sana un ligero incremento en el número de lecturas de pequeños RNAs de ambas polaridades en la región donde At4g39838 y At4g39840 se superponen (Figura 3.30). Esta observación sugiere que los pequeños RNAs originados en este locus, incluyendo al miR5658, se originan a partir del procesamiento de intermediarios de RNA bicatenario, probablemente resultantes de la transcripción convergente de estos genes.
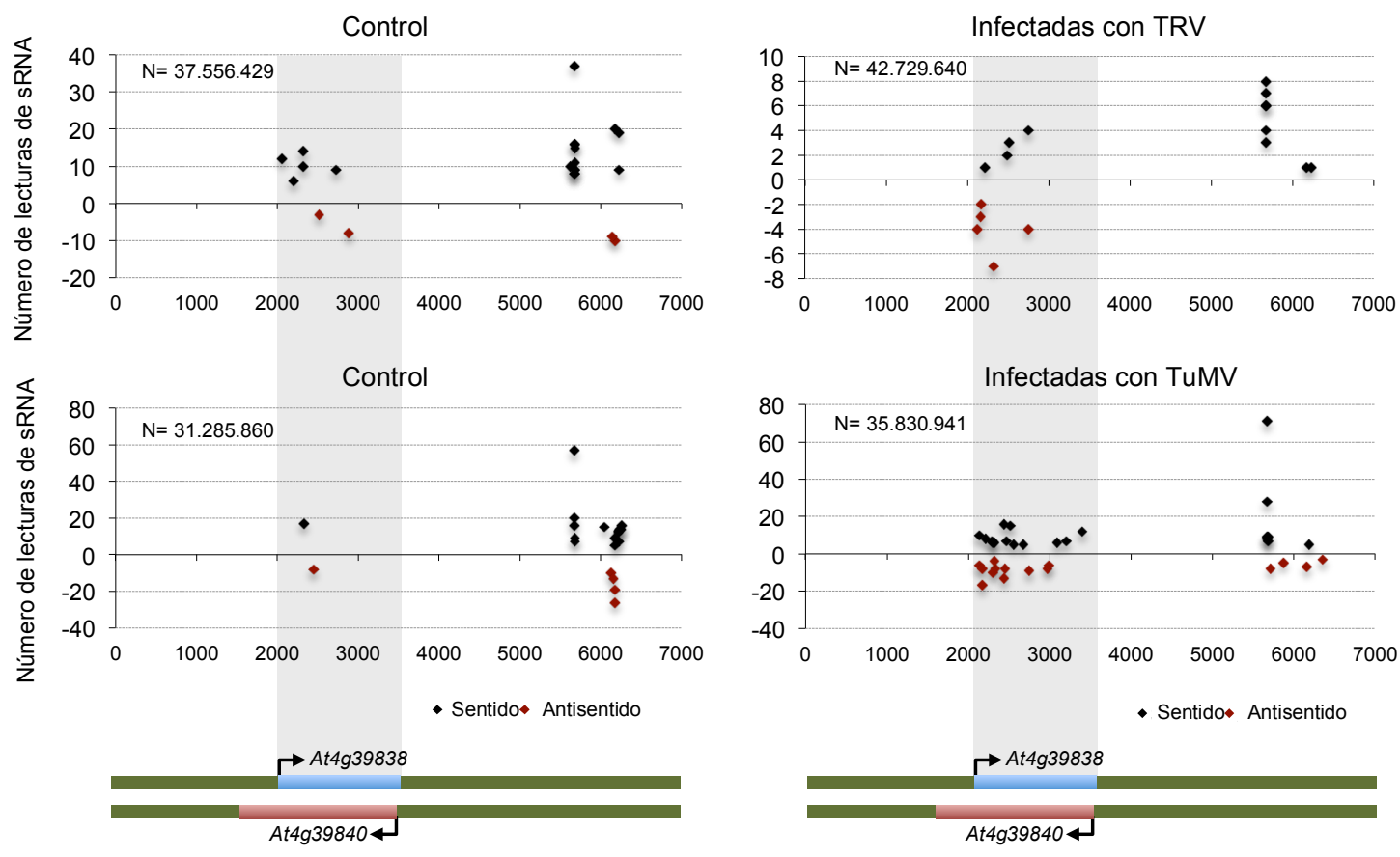

Figura 3.30. Distribución de las lecturas de sRNAs secuenciadas en hojas de roseta de Arabidopsis silvestres inoculadas con extracto de planta sana (control) o infectadas con TRV (arriba) o TuMV (abajo). La región sombreada señala la posición del locus At4g39838. Las especies de sRNAs sentido (puntos negros) y antisentido (puntos rojos) se representan como valores positivos y negativos en el eje Y, respectivamente. $\mathrm{N}$ representa el número total de secuencias filtradas. 


\subsubsection{Efecto del locus $M I R 5658$ en la regulación post-transcripcional de BIR1}

Para estudiar la función del locus que contiene el hipotético miR5658, genotipamos dos líneas de inserción de T-DNA (SALK_093172C y SALK_091507C) para el gen At4g39838 con inserciones localizadas aguas arriba de la secuencia predicha como precursora del miR5658 (Figura 3.31A). Mediante RT-PCR pudimos detectar sin embargo la presencia de transcritos que comprendían la región precursora de miR5658 en plantas homocigotas para ambas líneas, aunque a niveles ligeramente menores que en plantas silvestres (Figura 3.31B). Los resultados obtenidos por qRT-PCR mostraban idénticos niveles de acumulación de transcritos de BIRl en plantas sanas y plantas inoculadas con extracto de planta sana tanto en el fondo genético silvestre como en cada una de las líneas T-DNA (Figura 3.32A). Igualmente, observamos el mismo patrón de inducción de $B I R 1$ en hojas infectadas de los tres fondos genéticos a los 8 dpi (Figura 3.32A). De estos resultados se deduce que las líneas T-DNA analizadas deben retener funciones relacionadas con la hipotética actividad del miR5658. Además mediante qRTPCR observamos que TRV acumulaba a niveles similares en plantas silvestres y en las líneas T-DNA SALK_093172C y SALK_091507C (Figura 3.32B).

A

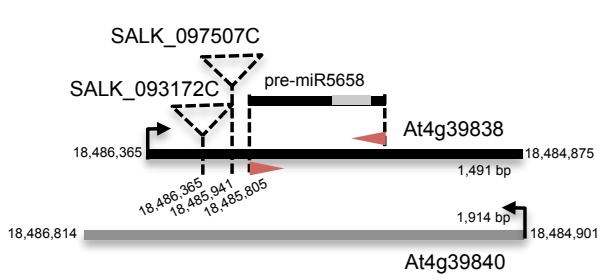

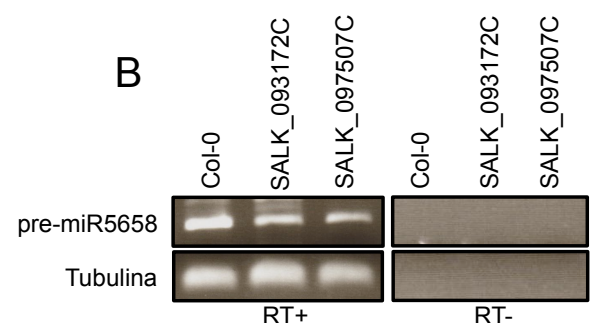

$\mathrm{RT}+$

RT-

Figura 3.31. A) Diagrama esquemático del locus At4g39838 en Arabidopsis. Las posiciones de inserción de los T-DNA de las líneas SALK_097507C y SALK_093172C están señalizadas con triángulos de puntos. Los sitios de inicio de la transcripción se indican con flechas negras. B) Análisis de RT-PCR de los transcritos del precursor del miR5658 en Arabidopsis silvestres (Col-0) y líneas de inserción T-DNA. El experimento se realizó con (RT+) y sin (RT-) transcriptasa inversa. El gen de la Tubulina se empleó como control interno. 
A

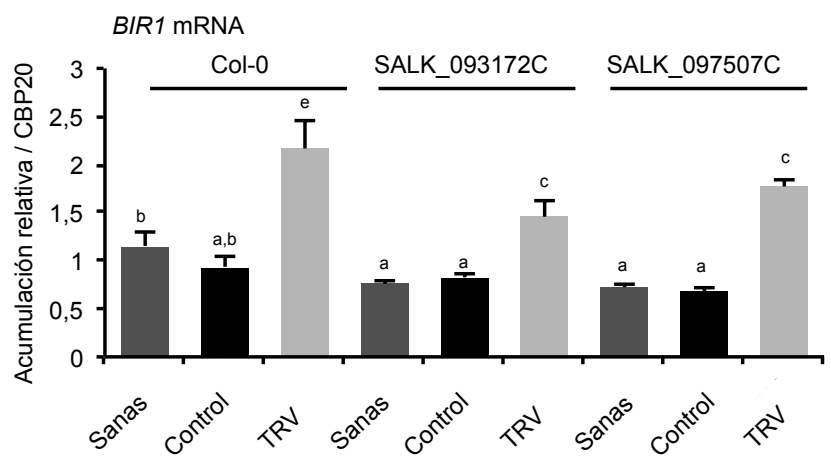

B

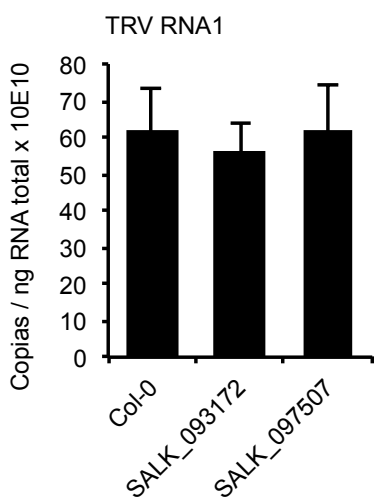

Figura 3.32. A) Acumulación relativa, mediante qRT-PCR, de transcritos de BIRI. B) Acumulación absoluta del RNA1 genómico de TRV. Las muestras analizadas proceden de hojas de roseta de Arabidopsis silvestres (Col-0) y líneas de inserción T-DNA no inoculadas (sanas), inoculadas con extracto de planta sana (control) o inoculadas con TRV. Las distintas letras indican diferencias estadísticamente significativas $(P<0,001)$.

A pesar de no poder detectar el miR5658 es posible que el locus At4g39838 influya en la expresión de BIRl a través de mecanismos dependientes de secuencia. Para comprobarlo generamos dos construcciones precursoras de miR5658 bajo el promotor constitutivo $35 \mathrm{~S}$. Una de ellas contenía la secuencia del precursor flanqueada por las siguientes 200 pares de bases mientras que en la otra la región que la flanquea se extendía hasta 500 pares bases (Figura 3.33). A continuación empleamos ensayos de expresión transitoria en $N$. benthamiana para co-expresar cada precursor de miR5658 y la construcción de $B I R 1$ silvestre descrita anteriormente. Mediante ensayos Western blot con anticuerpos frente al epítopo HA pudimos detectar una drástica reducción en la acumulación de la proteína BIR1 en los parches infiltrados con ambos precursores de miR5658 comparados con el vector vacío, que se empleó como control negativo (Figura 3.34A). Por el contario, el precursor miR5658 no tuvo efecto alguno sobre la acumulación de la proteína BIR1 cuando la construcción de BIRl carecía de la región 5'UTR (Figura 3.34A). Este resultado sugería que el efecto represivo del locus MIR5658 se dirigía hacia la región 5'UTR de BIR1. Los niveles de proteína BIR1 tampoco se vieron afectados con la co-expresión de miRNAs heterólogos (miR399, miR158 y miR171), independientemente de la presencia de la región 5'UTR de BIR1, sugiriendo que el efecto regulador del locus MIR5658 es específico de secuencia (Figura 3.34B). La co-expresión del precursor pre-miR5658 con la construcción BIR1 $\mathrm{mA}$ que contiene mutaciones en el punto de corte A en la región 5'UTR resultó en niveles de acumulación de proteína BIR1 menores que los observados en ausencia del precursor (Figura 3.34C). Este resultado sugiere que la regulación de BIRl dependiente del locus MIR5658 no está únicamente restringida a esta zona A de la región 5'UTR. Por último, cuando las construcciones precursoras de miR5658 se co-infiltraron con 
construcciones que contienen la secuencia de GFP sola o fusionada a la región 5'UTR de BIRl no observamos ningún efecto relevante en la acumulación de la proteína GFP respecto a lo observado en hojas infiltradas con vector vacío (Figura 3.34D). Estos resultados implican que el locus MIR5658 posee funciones reguladoras sobre BIR1 y que tanto la región 5'UTR como la secuencia codificadora de BIRl son requeridas para una regulación eficiente.

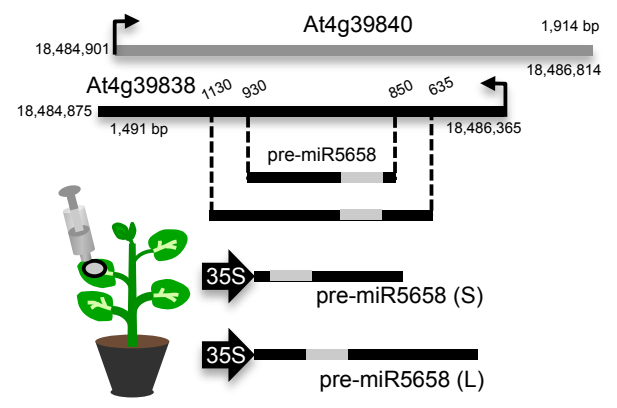

Figura 3.33. Representación esquemática de las secuencias precursoras del miR5658 en el locus At4g39838 empleadas en los ensayos de expresión transitoria. Se diseñaron dos construcciones bajo el promotor $35 \mathrm{~S}$ que contenían bien la región precursora con estructura secundaria (S) o la región estructurada más las secuencias (200 nts) que lo flanquean (L).

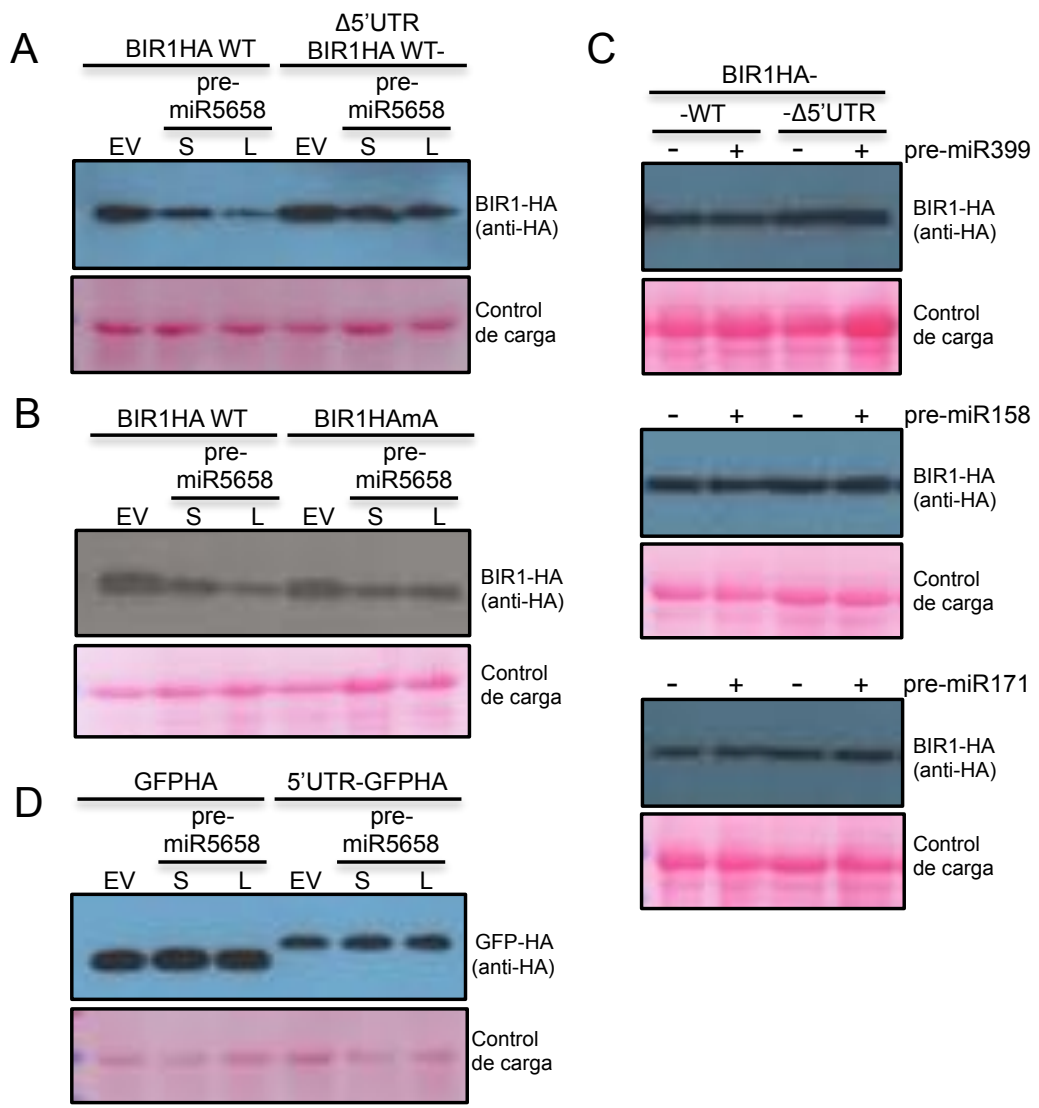

Figura 3.34. Determinación, mediante Western blot, de los niveles de proteína BIR1-HA (A, B y C) y GFP-HA (D) en presencia de precursores de miR5658 y de miRNA heterólogos (miR399, miR158, miR171). La construcción $\Delta 5$ 'UTR BIR1HA carece de región 5'UTR. Todas las construcciones se agroinfiltraron en $N$. benthamiana a una $\mathrm{DO}_{600}$ de 0,4 a excepción de las construcciones GFP-HA y 5'UTR (BIR1)-GFP-HA que se agroinfiltraron a una $\mathrm{DO}_{600}$ de 0,2. En todos los casos se ajustaron los cultivos a una $\mathrm{DO}_{600}$ final de 0,8 . La infiltración de las hojas con un vector vacío (VV) se usó como control. Las muestras se recogieron a 2 dpi y las membranas se incubaron en anticuerpo anti-HA. La membrana teñida con rojo Ponceau se muestra como control de carga. 


\subsubsection{Efecto del silenciamiento génico en la regulación post-transcripcional de BIR1}

La existencia de sitios de corte preferente en el RNA mensajero de BIRl es consistente con la actividad de endonucleasas guiadas por pequeños RNAs (Borges and Martienssen, 2015). El análisis de las genotecas de pequeños RNAs generadas en nuestro laboratorio revelaba la producción masiva de siRNAs en la región codificadora de BIRl en plantas infectadas con TRV pero no en plantas control (Figura 3.35A) Este hecho constituye un indicio sólido de que BIRl está sujeto a un silenciamiento posttranscripcional en respuesta a TRV. La acumulación diferencial de siRNAs derivados de BIRl también se observó en la ultrasecuenciación de genotecas de plantas inoculadas con TuMV comparado con los controles inoculados con extracto de planta sana (Figura 3.35B). Esto indica que el silenciamiento post-transcripcional de BIR1 no se circunscribe solamente a la infección con TRV. A partir de estas observaciones es posible especular que los siRNA derivados de BIRl podrían guiar el auto-silenciamiento de su RNA mensajero.

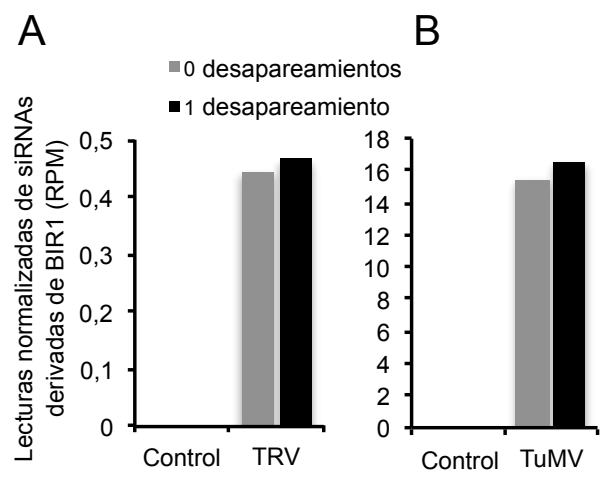

Figura 3.35. Comparación de la acumulación de siRNAs derivados de BIRl determinada por ultrasecuenciación entre plantas inoculadas con extracto de planta sana (control) y plantas infectadas con TRV (A) o TuMV (B). Se muestran los resultados de los alineamientos de secuencia empleando 0 ó 1 desapareamiento.

Si BIR1 experimenta silenciamiento post-transcripcional mediado por RNA deberíamos detectar un incremento de transcritos de BIRl en mutantes de Arabidopsis impedidos en esta ruta. Para comprobar esta hipótesis analizamos la expresión relativa de $B I R 1$ en mutantes de Arabidopsis defectivos en la biogénesis y función de pequeños RNAs. Cuando el ensayo se realizó en plantas control sin infectar los resultados de la qRT-PCR mostraban cierta variabilidad entre réplicas independientes si bien se detecta un ligero incremento $\mathrm{n}$ los niveles de transcritos de BIRl en algunos mutantes con defectos genéticos en enzimas DCL y RDR (Figura 3.36A) (Figura 3.36B). Estos resultados sugieren un control post-transcripcional de BIRl probablemente condicionado por factores ambientales. 
Cuando los transcritos de $B I R I$ se analizaron en plantas infectadas, observamos que BIRl se inducía en el doble mutante $d c l 2-1 d c l 3-1$ tanto como en las plantas silvestres (Figura 3.36A). Por el contrario los transcritos de BIR1 fueron significativamente abundantes en dcl2-1 dcl4-2, dcl3-1 dcl4-2 o dcl2-1 dcl3-1 dcl4-2 comparado con las plantas silvestres (Figura 3.36A). De este resultado se deduce que la función de DCL4 previene la acumulación excesiva de $B I R l$ en el tejido infectado. Igualmente los transcritos de BIRl fueron, en general, más abundantes en los mutantes $r d r 2-1 r d r 6-15$, rdr1-1 rdr6-15 y rdr1-1 rdr2 rdr6-15 que en las plantas silvestres (Figura 3.36B). Finalmente observamos que los niveles de transcritos de BIRl eran similares en planta silvestre inoculada con tampón y en mutantes ago1-27, mientras que durante la infección con TRV los transcritos de BIRl fueron mucho más abundantes en agol-27 que en plantas silvestres (Figura 3.36C). Estos resultados fueron similares a los observados en plantas infectadas con TuMV, confirmando que el silenciamiento posttranscripcional de BIRl se acentúa en respuesta a las infecciones con virus (Figura 3.36D). En vista de nuestros resultados podemos concluir que el silenciamiento posttranscripcional es un regulador de BIRl clave durante las infecciones virales. 

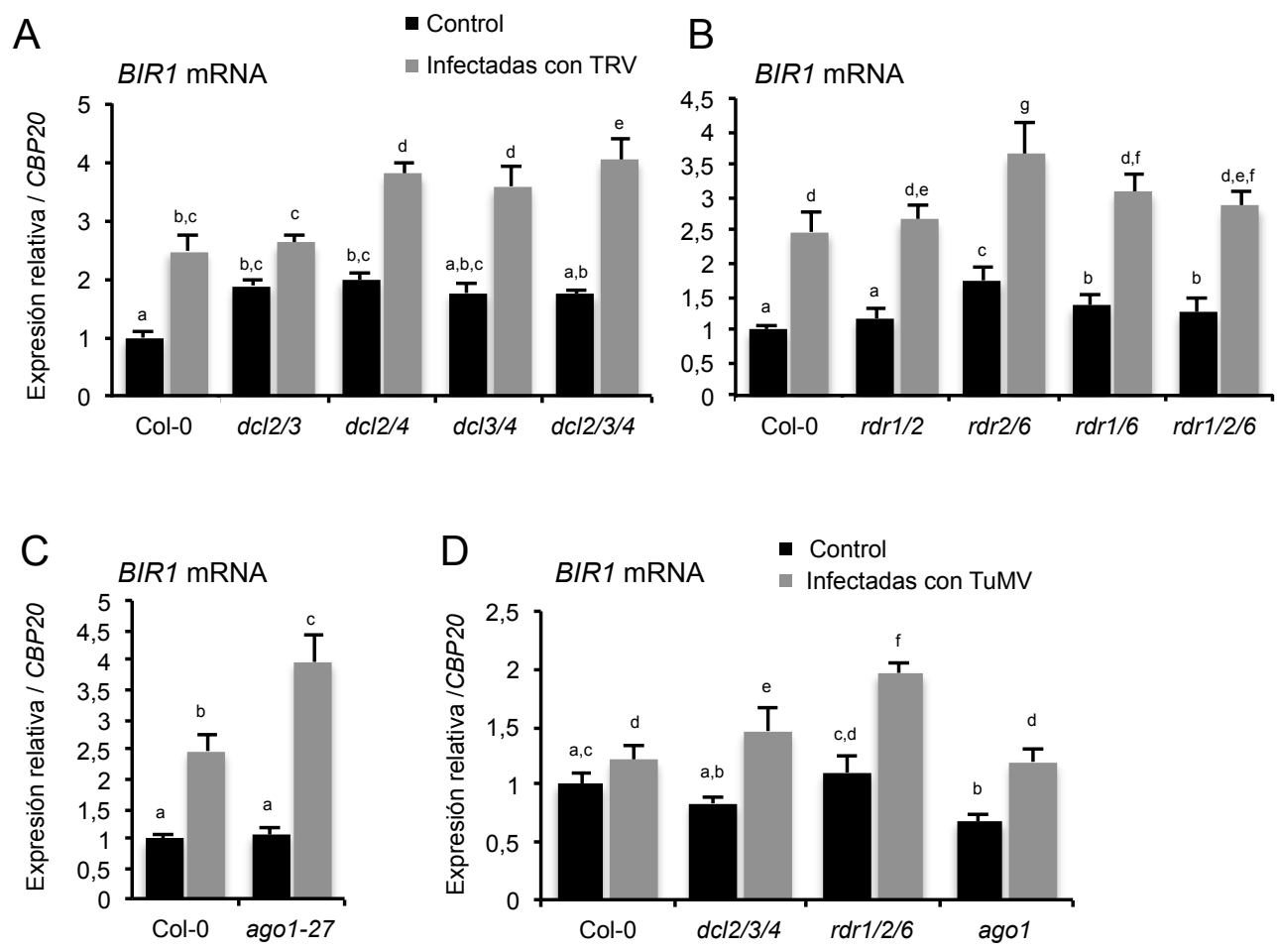

Figura 3.36. Acumulación relativa, mediante $q R T-P R C$, de transcritos de $B I R l$ en Arabidopsis silvestres (Col-0) y mutantes defectivas en el silenciamiento de RNA inoculadas con extracto de planta sana (control) o inoculadas con TRV (A, B, C) o TuMV (D). A) Análisis de mutantes defectivos en la biogénesis de siRNA (dcl2-1 dcl3-1 (dcl2/3), dcl2-1 dcl4-2 (dcl2/4), dcl3-1 dcl4-2 (dcl3/4) ó dcl2-1 dcl31 dcl4-2 (dcl2/3/4)). B) Análisis de mutantes defectivos en la biogénesis de siRNA secundarios $(r d r 1-1$ rdr2-1 (rdr1/2), rdr2-1 rdr6-15 (rdr2/6), rdr1-1 rdr6-15 (rdrl1/6) ó rdr1-1 rdr2-1 rdr6-15 (rdr1/2/6)). C) Análisis de mutantes defectivos en la función de $A G O 1$ (ago1-27). D) Análisis de mutantes defectivos en el silenciamiento de RNA (dcl2-1 dcl3-1 dcl4-2 (dcl2/3/4), rdr1-1 rdr2-1 rdr6-15 (rdr1/2/6) y ago1-27). Los valores se relativizaron respecto al genotipo silvestre control (valor 1.0). Las distintas letras indican diferencias estadísticamente significativas $(P<0,001)$.

\subsection{Relevancia biológica de la regulación de BIR1}

\subsubsection{Análisis de la función estabilizadora de BIR1 en un sistema heterólogo de expresión transitoria}

Trabajos anteriores de otros autores sugieren que la interacción de BIR1 con BAK1 contribuye a la estabilización de BAK1 (Gao et al., 2009; Ma et al., 2017). En línea con esta idea, la co-expresión del homólogo BIR3 y BAK1 en el sistema heterólogo de expresión transitoria en $N$. benthamiana resulta en una mayor acumulación de proteína BAK1 en la zona infiltrada (Imkampe et al., 2017). Para determinar si BIRl es capaz de aumentar la estabilidad de otras proteínas reprodujimos las condiciones experimentales descritas por (Imkampe et al., 2017) para analizar la acumulación de una proteína reportera GFP en presencia de BIR1. Al agroinfiltrar ambas construcciones en hojas de $N$. benthamiana observamos un incremento notable en la intensidad de la fluorescencia bajo luz ultravioleta en parches que contenían BIR1 respecto a los controles infiltrados 
con vector vacío (Figura 3.37A). Esta observación es coherente con lo observado en ensayos Western blot empleando anticuerpos frente al extremo N-terminal de la GFP donde se muestra un aumento significativo en la acumulación de proteína GFP en presencia de BIR1 respecto al control (Figura 3.37B). Este efecto es similar al observado cuando este sistema heterólogo se emplea para valorar la capacidad supresora de silenciamiento de ciertas proteínas (Martinez-Priego et al., 2008). De hecho la fluorescencia y la acumulación de proteína GFP en hojas infiltradas con BIR1 era equiparable a lo observado en presencia del supresor viral de silenciamiento HC-Pro (Figura 3.37A y 3.37B). Esto nos llevo a pensar que BIR1 podría también contribuir a estabilizar los transcritos de GFP. Sin embargo, los experimentos Northern blot con una sonda específica para la GFP mostraban que si bien los transcritos de GFP acumulaban ligeramente más en presencia de BIR1, la señal observada no era comparable a la obtenida con los transcritos detectados en la combinación de GFP y HC-Pro (Figura 3.37C). Estos datos sugieren que la capacidad de BIR1 para incrementar los niveles de proteínas a partir de construcciones co-infiltradas en hojas de $N$. benthamiana no parece deberse a un efecto inhibidor sobre la degradación de RNAs mensajeros. Nuestros resultados mostraban ausencia de fluorescencia en parches infiltrados con GFP, BIR1 y una construcción que producía un RNA bicatenario para la secuencia GFP (dsGFP) (Figura 3.37A). La ausencia de fluorescencia en la zona infiltrada, que ocurre incluso a dosis muy bajas de inductor $\left(\mathrm{DO}_{600}<0,001\right)$, coincide con niveles indetectables de proteína GFP en contraste con lo observado en presencia del supresor HC-Pro (Figura 3.37B). De acuerdo con estas observaciones BIR1 fue incapaz de estabilizar los transcritos de la construcción GFP, al contrario que HC-Pro (Figura 3.37C). De nuestros resultados podemos concluir que BIR1 potencia la síntesis y/o estabilidad de proteínas expresadas en el sistema heterólogo si bien esta propiedad no parece radicar en una actividad supresora de silenciamiento. 
A

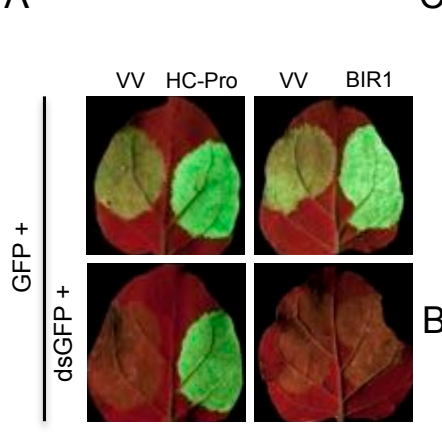

C

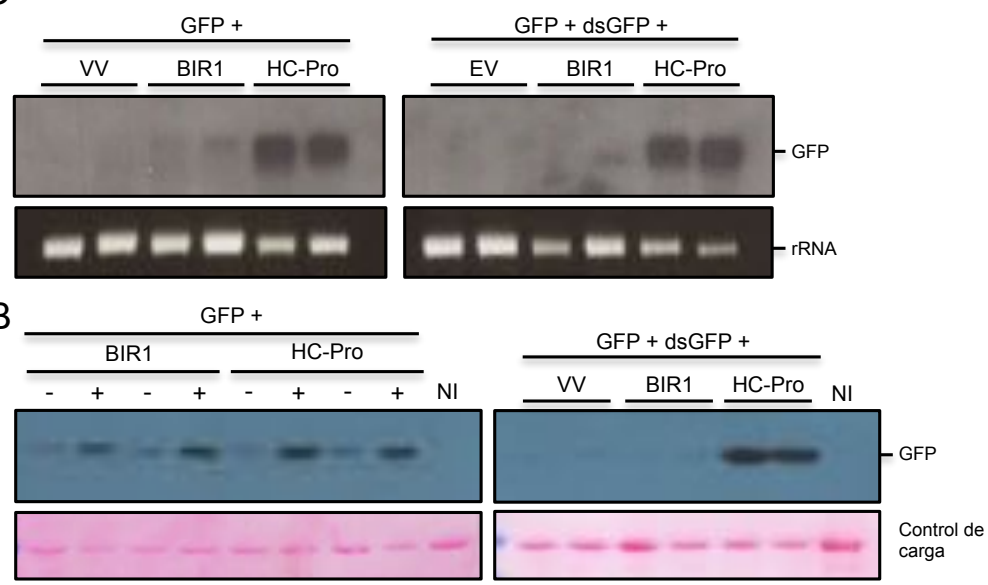

Figura 3.37. A) Fotografía bajo luz ultravioleta de la fluorescencia producida por la proteína GFP en hojas de $N$. benthamiana infiltradas con BIR1, con HC-Pro o con vector vacío (control). B) Determinación, mediante Western blot, de los niveles de proteína GFP empleando un anticuerpo antiGFP (N-terminal). Las membranas teñidas con rojo Ponceau se muestran como control de carga. C) Determinación, mediante Northern blot, de los niveles de transcrito de GFP empleando una sonda específica de GFP marcada radioactivamente. Las muestras analizadas proceden de parches de hoja de $N$. benthamiana infiltrados con GFP (izquierda) o GFP y dsGFP (derecha) en presencia de vector vacío (VV), BIR1 o a HC-Pro. Todas las construcciones se agroinfiltraron a una $\mathrm{DO}_{600}$ de 0,3 excepto la construcción dsGFP que se agroinfiltró a una $\mathrm{DO}_{600}$ de 0,01. En todas las construcciones se ajustó la $\mathrm{DO}_{600}$ final a 0,8 . Las muestras se recogieron a 2 dpi. La acumulación de rRNA se muestra como control de carga.

\subsubsection{Relevancia biológica de la regulación de BIR1: abordaje experimental}

Los resultados obtenidos hasta el momento demostraban que BIRl está sujeto a una doble regulación durante la infección por virus que implica la activación transcripcional dependiente de SA de su promotor y el silenciamiento post-transcripcional de sus RNA mensajeros. A partir de estas observaciones nos planteamos cual podría ser la relevancia biológica de dicha regulación en el contexto de la infección. Dado que BIRl se induce en presencia del virus y los mutantes birl-1 exhiben resistencia frente a TRV, es posible que su ganancia de función en el tejido infectado se asocie con un fenotipo de hipersusceptibilidad. Para contestar a esta pregunta empleamos dos abordajes experimentales complementarios destinados a sobreexpresar BIRl en la planta. Ambas estrategias se emplearon para expresar tanto la versión silvestre de BIRl como los derivados mutantes que contenían alteraciones en las secuencias de corte definidas por el análisis del degradoma.

\section{1) Expresión de BIRl en células infectadas mediada por TRV}

Esta aproximación se basa en el uso de TRV como vector viral para la expresión de genes exógenos (no virales) en planta. Para ello creamos una serie de vectores virales en los que el RNA2 de TRV se modificó genéticamente para albergar la secuencia 
codificadora de BIR1, incluida su región 5' UTR, fusionada en el extremo 3' al epítopo HA. La secuencia de BIRl se expresaba bajo el control del promotor de la replicasa del virus PEBV a través de un RNA subgenómico (Figura 3.38). Al igual que el resto de las proteínas virales, BIRl se traduce activamente en todas las células en las que TRV se replica.

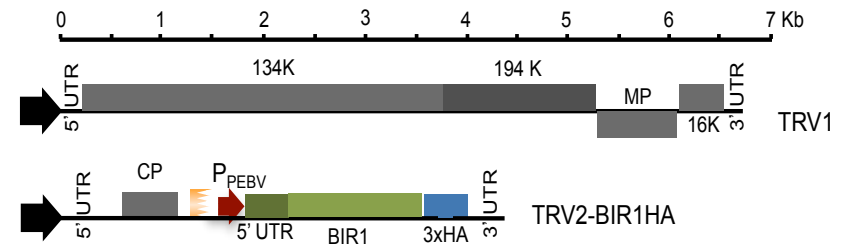

Figura 3.38. Diagrama representativo del clon infeccioso de TRV empleado para la expresión de BIRl-HA y sus variantes de secuencia. La secuencia codificadora de BIR1 incluyendo la región 5'UTR se insertó junto al promotor de la replicasa de PEBV en el pTRV2.

\section{2) Expresión inducible de BIR1 en plantas transgénicas de Arabidopsis}

Para caracterizar los efectos de la ganancia de función de BIRl fuera del contexto de la infección viral generamos plantas transgénicas de Arabidopsis que expresaban la secuencia codificante del gen BIRl, incluida la región 5' UTR, fusionada en su extremo C-terminal con el marcador fluorescente monomérico mCherry en un sistema inducible por DEX (Marques-Bueno et al., 2016) (Figura 3.39).

pIRN-BIR1 WT (2x35S::GVG-TE9::6xUAS-35Smini - BIR1-mCherry)

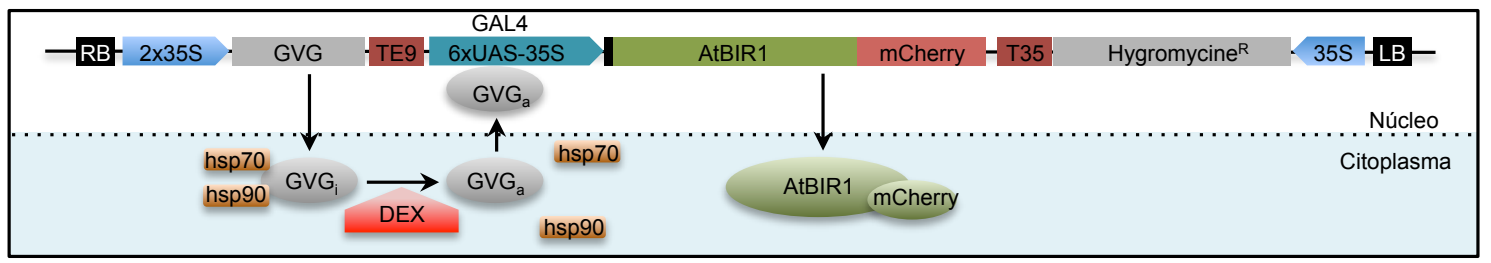

Figura 3.39. Esquema representativo de la construcción que expresa $B I R l$ conjugado con el reportero mCherry bajo un promotor inducible por DEX. La aplicación de la DEX convierte la proteína GVG a su forma activa, quedando liberada de las proteínas de choque térmico HSP70 y HSP90. GVG se une a la región promotora $35 \mathrm{~S}$ para activar la transcripción de la secuencia codificadora de la proteína BIR1mCherry.

\subsubsection{Expresión de BIR1 mediada por el vector viral TRV-BIR1}

\subsection{Ensayo de infectividad de vectores virales TRV-BIR1 en $N$. benthamiana}

Para determinar la infectividad de los vectores de TRV portadores de BIRI realizamos ensayos de agroinoculación en $N$. benthamiana y analizamos por qRT-PCR la acumulación viral en hojas superiores (no-infiltradas) usando como control de referencia el clon infeccioso TRV-GFP. Las muestras se analizaron a los 5 dpi dado que 
a ese tiempo podíamos observar fluorescencia derivada de la GFP en las hojas apicales más jóvenes. Los resultados obtenidos mostraban niveles comparables de acumulación viral en plantas infectadas con TRV-GFP y TRV-BIR1 WT (Figura 3.40). Además de la forma silvestre de $B I R 1$ se generaron vectores que contenían versiones mutadas para los sitios de degradación del RNA mensajero de BIRl. Así la construcción TRV-BIR1 $\mathrm{mBmCmD}$ portaba alteraciones en la secuencia de los sitios de corte $\mathrm{B}, \mathrm{C}$ y D, mientras que TRV-BIR1 mA1 presentaba mutaciones en el sitio A. Para este sitio de degradación se construyeron dos vectores adicionales denominados TRV-BIR1 mA2 y mA3 que portaban mutaciones en secuencias diana secundarias; una introducía dos tripletes en la posición 150 (TRV2-BIR1 mA2) y otra delecionaba tres aminoácidos en posición 169 (TRV2-BIR1 mA3) (Figura 3.41). El ensayo de infectividad en $N$. benthamiana mostró idénticos niveles de acumulación de RNA viral para cada una de las variantes analizadas (Figura 3.40). De estos ensayos concluimos que todas construcciones ensayadas eran infectivas en $N$. benthamiana acumulándose las formas replicativas del virus en hojas superiores a niveles comparables al control TRV-GFP. Ninguno de estos clones infecciosos provocó alteraciones morfológicas en el hospedador diferentes a las causadas por TRV-GFP.
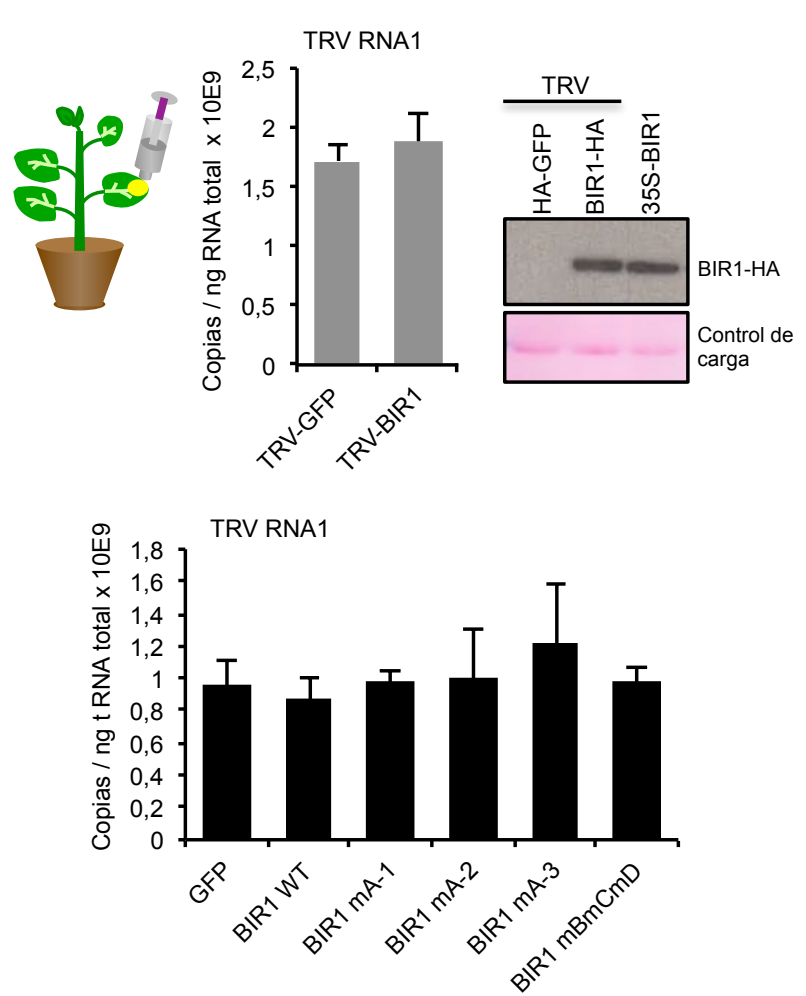

Figura 3.40. Acumulación, mediante qRT-PCR, de los transcritos de RNA1 de TRV en hojas superiores de $N$. benthamiana no agroinfiltradas. Determinación, mediante Western blot, de los niveles de proteína BIR1 empleando un anticuerpo anti-HA. Las membranas teñidas con rojo Ponceau se muestran como control de carga (arriba). La tercera y la cuarta hoja de la planta se agroinfiltraron a una $\mathrm{DO}_{600}$ final de 0,8 con el TRV1 y las distintas versiones de TRV2-BIR1 (WT, mA-1, mA-2, mA-3 y $\mathrm{mBmCmD}$ ). TRV2-GFP se usó como control. 


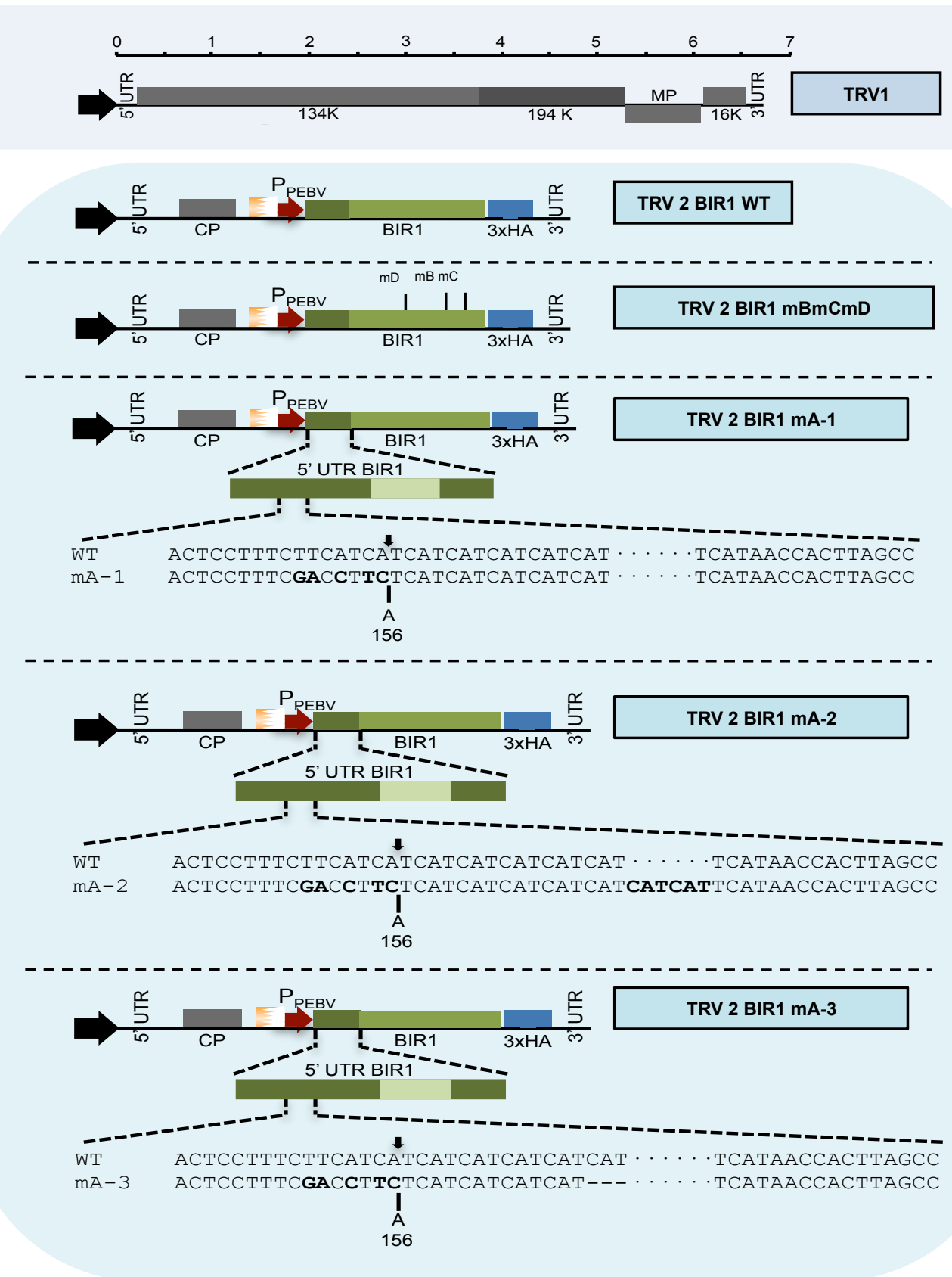

Figura 3.41. Diagrama esquemático de las construcción derivadas de TRV2 empleadas para la expresión de las distintas versiones de secuencia de BIRl con las mutaciones descritas en el apartado 3.5.2.1.1. La posición de los sitios de corte mutados $\mathrm{mB}, \mathrm{mC}$ y $\mathrm{mD}$ se muestra en el diagrama dentro de la región codificadora de BIR1. En el diagrama expandido se muestra la posición del sitio de corte A en posición 156.

De nuestros datos podemos inferir que el nivel de expresión de BIRl en $N$. benthamiana no compromete la capacidad infectiva del virus. Para comprobar esta idea analizamos el efecto local de BIRl sobre la acumulación de TRV-GFP o TuMV-GFP en parches infiltrados de $N$. benthamiana. Mediante ensayos Western blot analizamos la acumulación de proteína GFP usando anticuerpos frente a su extremo N-terminal como 
estimador de la abundancia de virus en la zona infiltrada. Los resultados obtenidos mostraban niveles comparables de GFP en parches infiltrados con BIRI o con vector vacío, usado como control del experimento (Figura 3.42). Así mismo, la proteína GFP se acumulaba igual tanto en presencia de la forma silvestre como de cada uno de los mutantes generados (Figura 3.42). Como era de esperar, la proteína BIR1 derivada de los transcritos mutantes $\mathrm{mCmD}$ y $\mathrm{mBmCmD}$ era significativamente más abundante en el parche infiltrado que el resto (Figura 3.42). De estas observaciones concluimos que la expresión transitoria de la proteína BIR1 de Arabidopsis en $N$. benthamiana no tiene aparentemente ningún efecto sobre la acumulación de TRV o TuMV en los parches infiltrados.

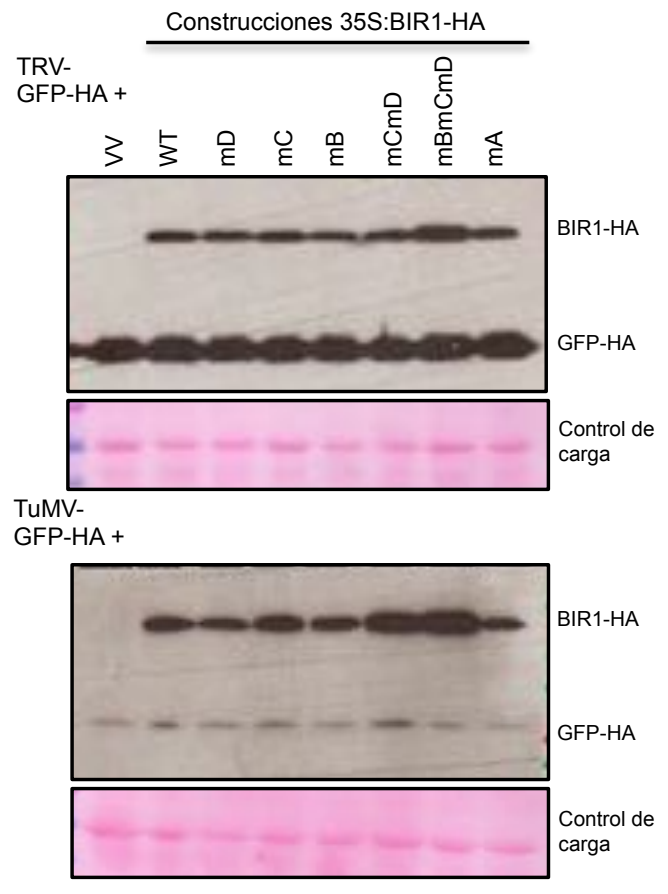

Figura 3.42. Determinación, mediante Western blot, de los niveles de acumulación de la proteína GFP-HA y BIR1-HA empleando anticuerpo anti-HA en expresión transitoria en hojas agroinfiltradas de $N$. benthamiana. Todas las construcciones se agroinfiltraron a una $\mathrm{DO}_{600}$ final de 0,8 . La infiltración del vector vacío (VV) sirvió como control. Las membranas teñidas con rojo Ponceau se muestran como control de carga.

\subsection{Efecto de las mutaciones en los puntos de corte sobre la expresión de} BIRI en plantas infectadas de $N$. benthamiana

Los ensayos de expresión transitoria de BIRl bajo el promotor constitutivo 35S sugerían que la combinación de mutaciones en los sitios B, C y D proporcionaba mayor estabilidad a los transcritos de BIRI facilitando la acumulación de proteína. Por el contrario, la mutación de la secuencia de corte A no conseguía estabilizar completamente el RNA mensajero de BIRl ni tampoco un incremento significativo en la acumulación de la proteína (ver apartado 3.4.2). Para corroborar esta observación en el contexto de una infección, analizamos el patrón de acumulación de proteína BIRl 
recombinante en plantas de $N$. benthamiana infectadas con cada uno de los clones infecciosos TRV-BIR1 descritos en la sección anterior. Las hojas superiores infectadas sistémicamente se recolectaron a los 4 dpi y se analizaron en ensayos de proteínas Western blot empleando anticuerpos frente al epítopo HA (Figura 3.43A). En conjunto, los resultados mostraban un grado de variabilidad intermuestral considerable. Sin embargo, el análisis densitométrico de las señales de hibridación de al menos 4 réplicas independientes mostraba un incremento significativo en la acumulación de proteína mutante BIR1 $\mathrm{mBmCmD}$ respecto al control de proteína BIR1 silvestre (WT) (Figura 3.43B). Por el contrario, no se apreciaban diferencias relevantes en la acumulación de proteínas mutantes BIR1 mA respecto al silvestre (Figura 3.43B). Estos datos corroboran nuestras observaciones previas poniendo de manifiesto la importancia de las secuencias B, C y D en la regulación post-transcripcional de BIRl también durante la infección.

A

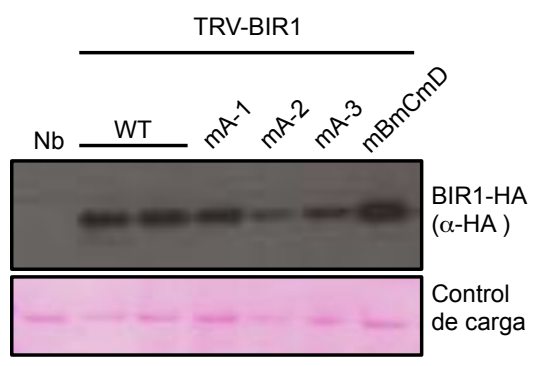

B

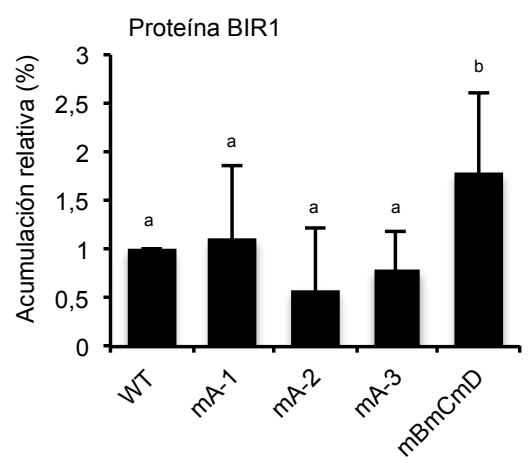

Figura 3.43. A) Determinación, mediante Western blot, de los niveles de acumulación de la proteína BIR1 silvestre (WT) y mutante $(\mathrm{mA} 1, \mathrm{~mA} 2, \mathrm{~mA} 3$ y $\mathrm{mBmCmD})$, empleando anticuerpo anti-HA. La membrana teñida con rojo Ponceau se muestra como control de carga. B) Acumulación de proteína BIR1 silvestre (WT) y mutante $(\mathrm{mA} 1, \mathrm{~mA} 2, \mathrm{~mA} 3$ y $\mathrm{mBmCmD})$, mediante análisis densitométrico de las bandas de hibridación obtenidas en ensayos Western blot empelando anticuerpo anti-HA. Los valores se relativizaron respecto a la proteína BIR1 WT (valor 1.0). El gráfico muestra la intensidad media de las bandas y la SD de cinco réplicas biológicas. Las distintas letras indican diferencias estadísticamente significativas $(P<0,001)$. Las muestras analizadas proceden de hojas de $N$. benthamiana agroinfiltradas a una $\mathrm{DO}_{600}$ final de 0,8 con el TRV1 y las distintas versiones de TRV2-BIR1 (WT, mA-1, mA-2, mA-3 y $\mathrm{mBmCmD}$ ). Las muestras se recogieron a $2 \mathrm{dpi}$.

Para estudiar el efecto regulador de la región 5'UTR de BIRl sobre la expresión de proteína generamos construcciones virales que portaban la secuencia codificadora de GFP precedida de la 5' UTR de BIRl en su forma silvestre o mutada (mA1). El análisis Western blot de hojas superiores no-inoculadas mostraba niveles de acumulación de proteína GFP ligeramente menores en plantas infectadas con el vector TRV-5'UTRGFP-HA que los alcanzados en plantas infectadas con el control TRV-GFP (Figura 3.44A). Sin embargo, el análisis densitométrico de las señales de hibridación mostraba 
que la mutación mA en la 5' UTR compromete la acumulación de proteína GFP en las hojas infectadas, lo que sugiere que la secuencia del sitio de corte A es determinante para la función de la región 5' UTR en la síntesis de proteína GFP (Figura 3.44B).

A

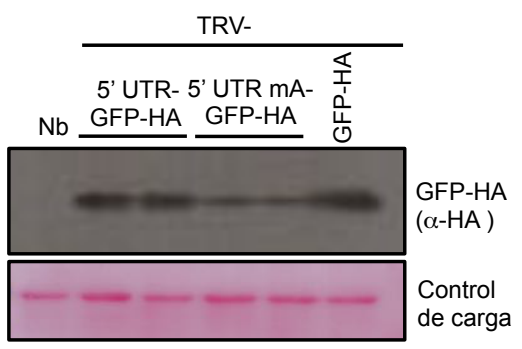

B

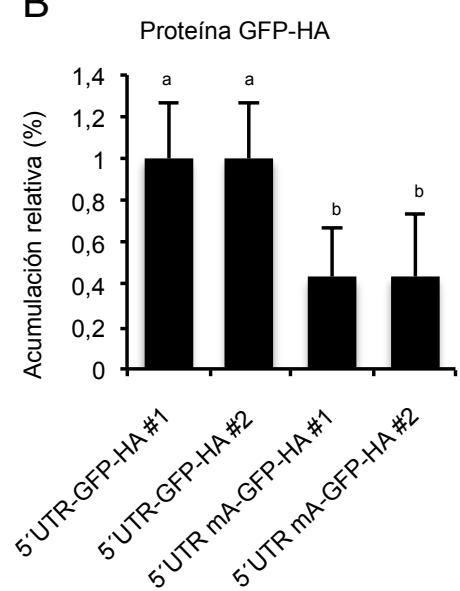

Figura 3.44. A) Determinación, mediante Western blot, de los niveles de acumulación de la proteína GFP-HA empleando un anticuerpo anti-HA. La membrana teñida con rojo Ponceau se muestra como control de carga. B) Acumulación de proteína GFP, mediante análisis densitométrico de las bandas de hibridación obtenidas en ensayos Western blot. Los valores se relativizaron respecto a la muestra infiltrada con la construcción TRV2-5'UTR-GFP-HA (valor 1.0). Las distintas letras indican diferencias estadísticamente significativas $(P<0,001)$. Las muestras proceden de hojas de $N$. benthamiana agroinfiltradas a una $\mathrm{DO}_{600}$ final de 0,8 con el TRV1 y el TRV2-5'UTR-GFP-HA en su versión silvestre o mutada (TRV2-5'UTRmA-GFP-HA). La construcción TRV-GFP se empleó como control positivo. Las muestras se recogieron a 2 dpi.

\subsection{Ensayo de infectividad de vectores virales TRV-BIR1 en Arabidopsis}

Para caracterizar los efectos de la sobreexpresión de BIRl en un contexto de infección viral inoculamos plántulas de Arabidopsis de tres semanas de edad con cada una de las construcciones virales TRV-BIR1 descritas en el apartado 3.5.2.1.1. Dado que no encontramos diferencias significativas en la acumulación de RNA viral en las hojas superiores de $N$. benthamiana entre las distintos vectores TRV-BIR1 y el control TRV-GFP empleamos el método tradicional de inoculación a partir de extracto de hoja infectada de $N$. benthamiana. A los 14 dpi observamos la aparición de fenotipos morfológicos en más del $80 \%$ de las plantas inoculadas con las distintas versiones de TRV-BIR1 (Figura 3.45A y B). Estos fenotipos no se apreciaban en plantas inoculadas con TRV-GFP ó con extracto de planta sana, cuya apariencia era idéntica a las plantas no tratadas (Figura 3.45A y B). Los distintos fenotipos observados consistían en enanismo, crecimiento aberrante, pérdida de dominancia apical, malformación de las hojas de la roseta y necrosis (Figura 3.45A y Tabla 1). 
A

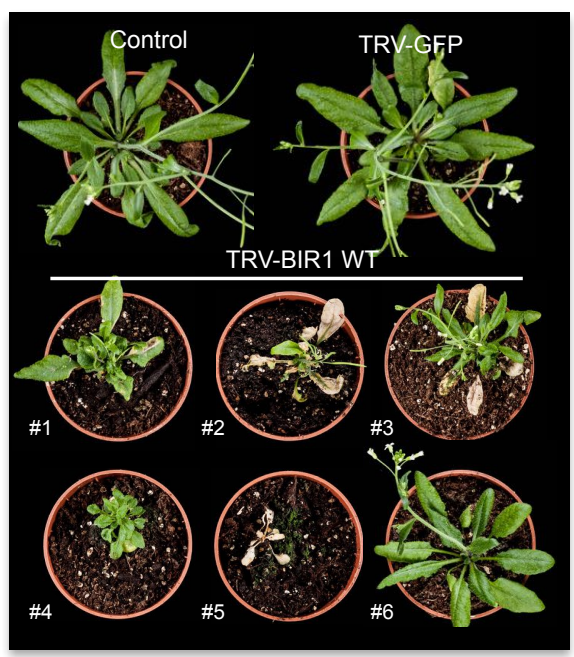

B

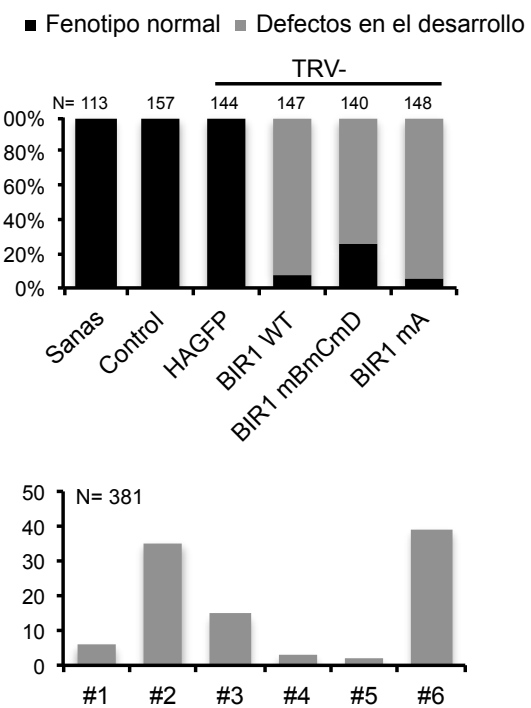

Figura 3.45. A) Fenotipos morfológicos en plantas de Arabidopsis inoculadas con extracto de planta sana (control) o con los vectores recombinantes TRV-GFP ó TRV-BIR1 WT. Las fotografías se tomaron a 14 dpi. Los fenotipos se clasificaron arbitrariamente en seis categorías según el tipo y la gravedad de las malformaciones (\#1 a \#6) (ver tabla 3.1). B) Distribución porcentual de fenotipos en plantas control no inoculadas o inoculadas con extracto de planta sana y en plantas infectadas con TRV-GFP y las distintas variantes derivadas de TRV-BIR1 (WT, $\mathrm{mA}, \mathrm{mBmCmD}$ ). $\mathrm{N}$ representa el número total de plantas analizadas.

\begin{tabular}{|c|c|}
\hline Fenotipo & Descripción \\
\hline$\# 1$ & $\begin{array}{l}\text { Pérdida de dominancia apical, enanismo, crecimiento aberrante y } \\
\text { malformación en las hojas de la roseta. }\end{array}$ \\
\hline \#2 & $\begin{array}{l}\text { Pérdida de dominancia apical, enanismo, crecimiento aberrante, } \\
\text { malformación en las hojas de la roseta y necrosis. }\end{array}$ \\
\hline$\# 3$ & $\begin{array}{l}\text { Enanismo, crecimiento aberrante, malformación en las hojas de la } \\
\text { roseta y necrosis. }\end{array}$ \\
\hline$\# 4$ & Enanismo extremo y pérdida de dominancia apical. \\
\hline \#5 & Necrosis masiva y muerte. \\
\hline$\# 6$ & Ligero retraso en el crecimiento. \\
\hline
\end{tabular}

Tabla 3.1. Descripción de los seis fenotipos morfológicos observados en plantas de Arabidopsis infectadas con TRV-BIR1 WT. 
Para facilitar en análisis de las muestras diferenciamos seis posibles fenotipos en función de la gravedad y del tipo de las lesiones (Tabla 3.1). Con el fin de determinar si la aparición de fenotipos morfológicos en plantas infectadas con TRV-BIR1 WT se correlacionaba con la sobreexpresión de BIR1 en tejido infectado, cuantificamos mediante qRT-PCR la acumulación de transcritos de BIRI en plantas individuales que mostraban cada uno de los fenotipos descritos. El análisis incluía plantas control no inoculadas y plantas infectadas con TRV-GFP. Los resultados obtenidos mostraron una acumulación de transcritos de BIRl por encima de los dos órdenes de magnitud en las plantas con fenotipos aberrantes extremos respecto a las plantas no inoculadas o infectadas con TRV-GFP (Figura 3.46A). Por el contrario, los transcritos de BIRl se acumulaban poco en las plantas que aun estando infectadas con TRV-BIR1 WT presentaban morfología silvestre o un ligero retraso en el crecimiento respecto al fenotipo silvestre (Figura 3.46A). Además, aquellos fenotipos que mostraron una mayor acumulación de transcritos de BIRl mostraron también una acumulación significativamente mayor de transcritos de los genes $P R 1$ y $P R 4$, lo que sugiere que la sobreexpresión de BIRl se asociaba a la inducción de genes de defensa (Figura 3.46A). 
A
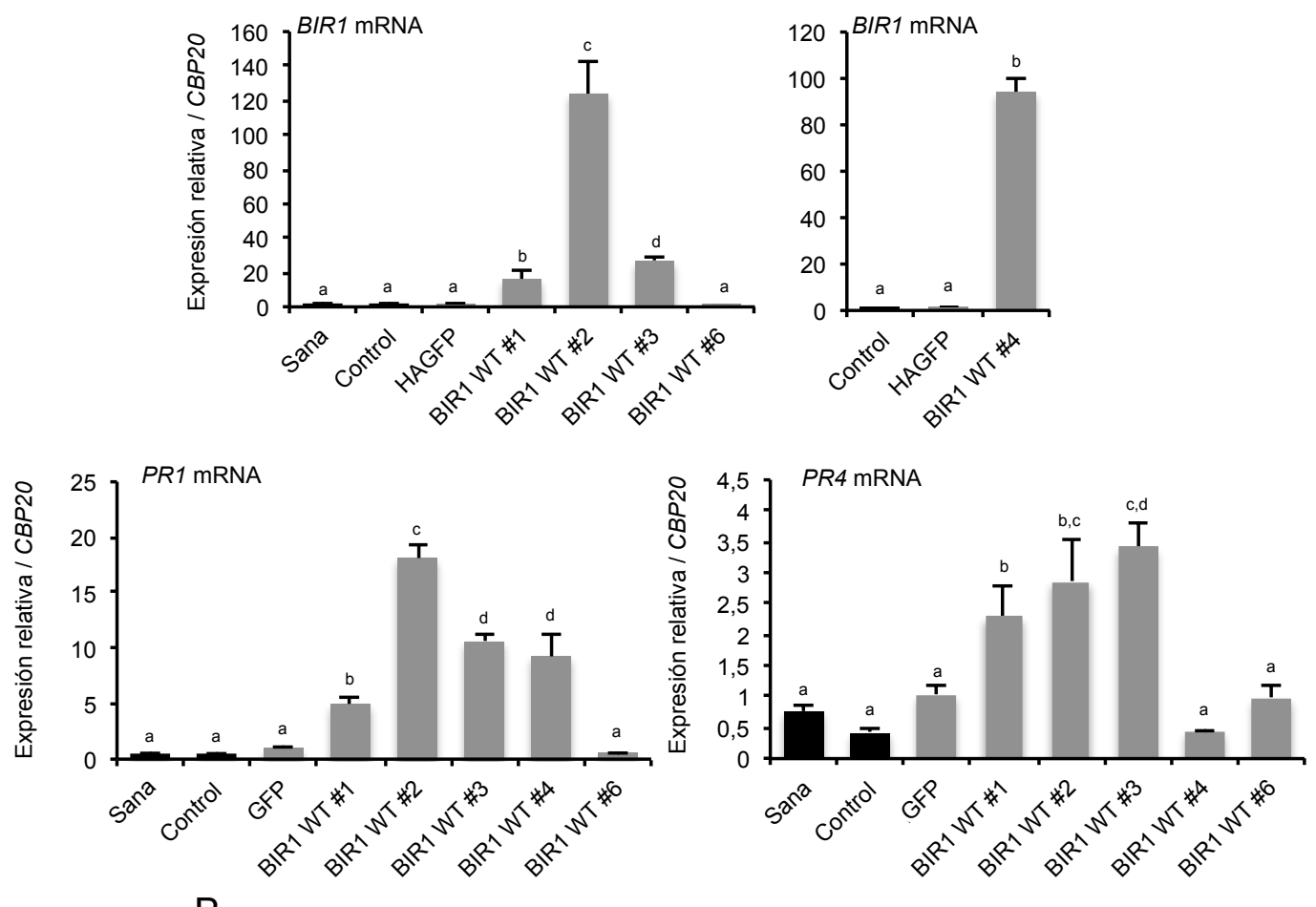

B
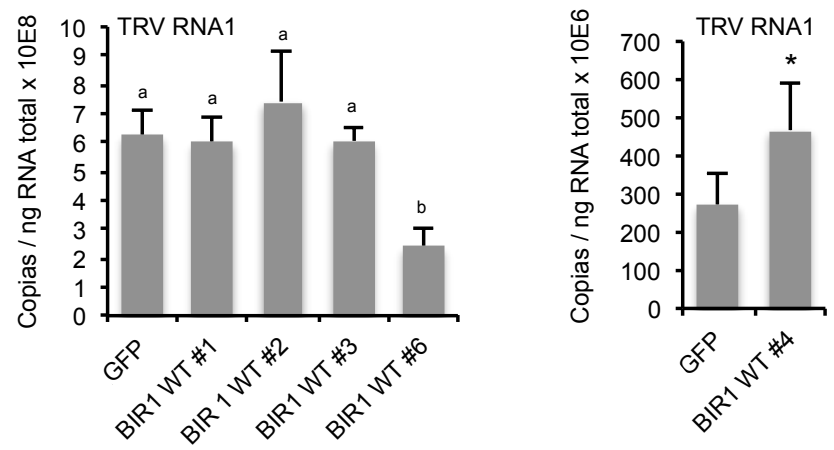

Figura 3.46. A) Acumulación relativa, mediante qRT-PCR, de los transcritos de $B I R 1, P R 1$ y $P R 4$ en plantas de Arabidopsis silvestres no inoculadas (sanas), inoculadas con extracto de planta sana (control) o infectadas con los vectores recombinantes TRV-GFP ó TRV-BIR1 WT. B) Acumulación del RNA1 genómico de TRV en plantas infectadas con TRV-BIR1 a los 14 dpi. Las plantas infectadas con TRVBIR1 se analizaron individualmente para cada fenotipo registrado (\#1, \#2, \#3, \#4, \#6). Las plantas con fenotipo \#5 no pudieron analizarse. Las distintas letras indican diferencias estadísticamente significativas $(P<0,001)$.

Idénticos resultados se obtuvieron cuando infectamos plantas de Arabidopsis con los vectores virales que contenían las versiones mutadas $\mathrm{mA}$ y $\mathrm{mBmCmD}$ de $B I R I$ (Figura 3.47A). En ambos casos se reprodujeron los mismos fenotipos que en las plantas infectadas con TRV-BIR1 WT y de igual modo las plantas con malformaciones graves acumulaban cantidades desproporcionadas de transcritos de BIRI respecto a las plantas control (Figura 3.47B). Cuando analizamos la acumulación de virus no fue posible establecer una correlación entre la acumulación de BIRl y TRV en las muestras 
analizadas (Bilateral Spearman correlation, $\rho=0,48, p=0,84$ ). Si bien la acumulación de RNA viral resultaba muy variable entre muestras, y ocasionalmente se veía reducida en plantas con deformaciones extremas, no parece que la sobreexpresión de $B I R l$ en si misma condicione la proliferación del virus en la planta (Figura 3.46B). Los resultados obtenidos demostraban que la sobreexpresión de $B I R 1$ en las células infectadas provoca graves malformaciones y defectos en el desarrollo y crecimiento de la planta. Por tanto, la regulación post-transcripcional de BIRl parece esencial para prevenir los efectos deletéreos asociados a su sobreexpresión.

A

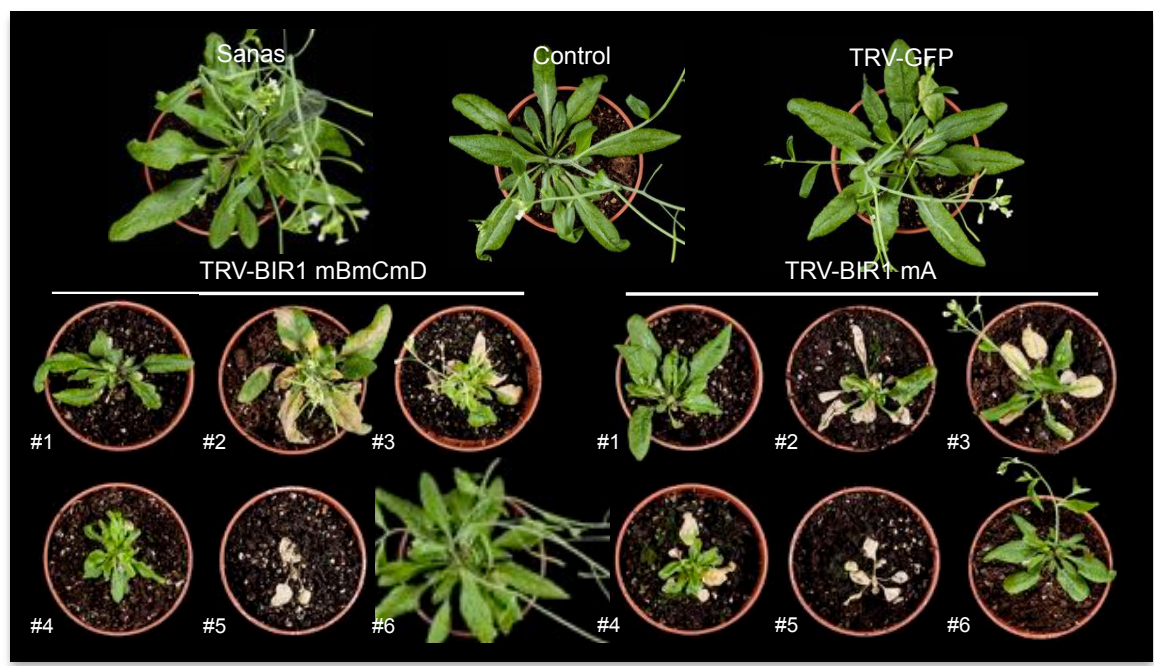

B
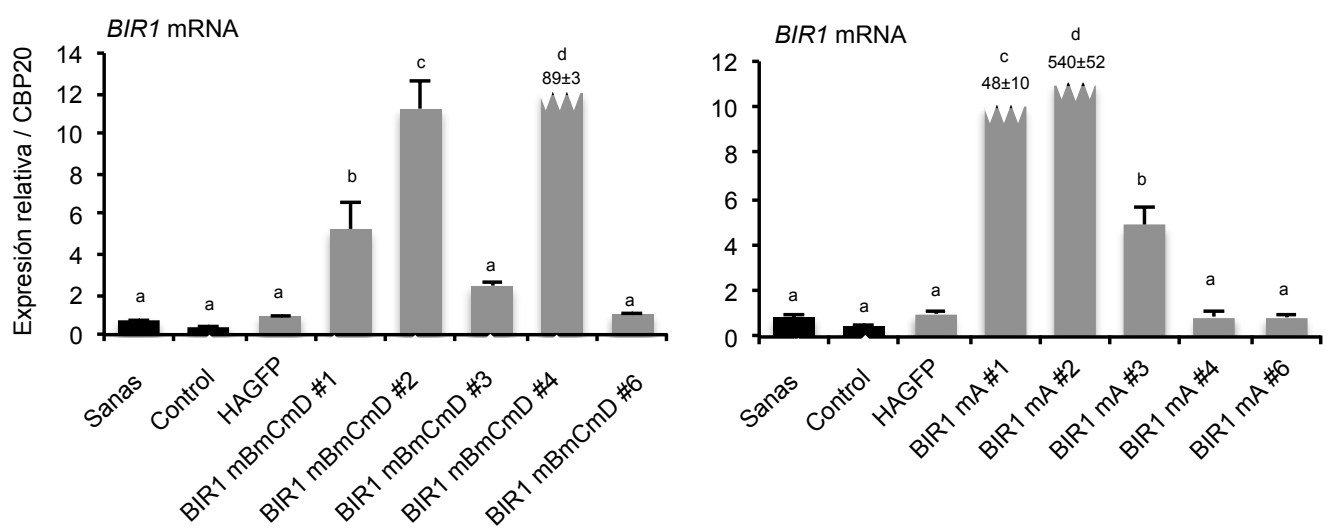

Figura 3.47. A) Fenotipos morfológicos en plantas de Arabidopsis inoculadas con extracto de planta sana (control) o con los vectores recombinantes TRV-GFP, TRV-BIR1 mA y TRV-BIR1 mBmCmD. Las fotografías se tomaron a $14 \mathrm{dpi}$. Los fenotipos se clasificaron arbitrariamente en seis categorías según el tipo y la gravedad de las malformaciones (\#1 a \#6) (ver tabla 3.1). B) Acumulación relativa, mediante qRT-PCR, de los transcritos de BIR1 en las plantas no inoculadas (sanas), inoculadas con extracto de planta sana (control) o infectadas con TRV-GFP, TRV-BIR1 mBmCmD ó TRV-BIR1 mA. Las plantas infectadas con se analizaron individualmente para cada fenotipo registrado (\#1, \#2, \#3, \#4, \#6). Las plantas con fenotipo \#5 no pudieron analizarse. Las distintas letras indican diferencias estadísticamente significativas, $P<0,05)$. 


\subsubsection{Expresión inducible de BIR1 en plantas transgénicas de Arabidopsis}

\subsection{Construcción de plantas transgénicas para BIR1 usando un sistema de expresión inducible}

Los resultados anteriores planteaban la cuestión de si los fenotipos morfológicos observados en las plantas infectadas con los vectores TRV-BIR1 se debían exclusivamente a la sobreexpresión de $B I R 1$ o, por el contrario, al efecto combinado de la sobreexpresión de BIRl y la infección viral. Para responder a esta pregunta generamos líneas transgénicas para la sobreexpresión de BIRl bajo el control de un promotor inducible por DEX (Marques-Bueno et al., 2016). Para ello se clonó la secuencia codificadora de BIRl precedida por la región 5' UTR en un vector binario GATEWAY que permitía fusionar la secuencia de BIRl en su extremo 3' con la secuencia codificadora de la proteína marcadora mCherry (Figura 3.39). Este abordaje se empleó tanto para la construcción silvestre de BIRl (WT) como para las variantes mutadas $\mathrm{mA}$ y $\mathrm{mBmCmD}$ descritas en el apartado 3.4.2.

Para comprobar la viabilidad de las construcciones generadas realizamos ensayos de expresión transitoria en $N$. benthamiana. Las construcciones se agroinfiltraron en células epidérmicas y al día siguiente se aplicó DEX por infiltración o pulverización de una solución $30 \mu \mathrm{M}$. Como control las plantas fueron tratadas con la misma solución sin DEX. A las $24 \mathrm{~h}$ del tratamiento con la hormona recogimos muestras del tejido y las analizamos por microscopía láser confocal empleando un microscopio LEICA TCS SP5. La observación de las muestras infiltradas con las construcciones silvestre y mutadas de BIRl permitió visualizar la fluorescencia derivada de la proteína de fusión BIR1-mCherry en hojas tratadas con DEX pero no en las hojas con el tratamiento control (Figura 3.48). La aplicación de la hormona por cualquiera de los dos métodos empleados fue igual de efectiva (Figura 3.48). 

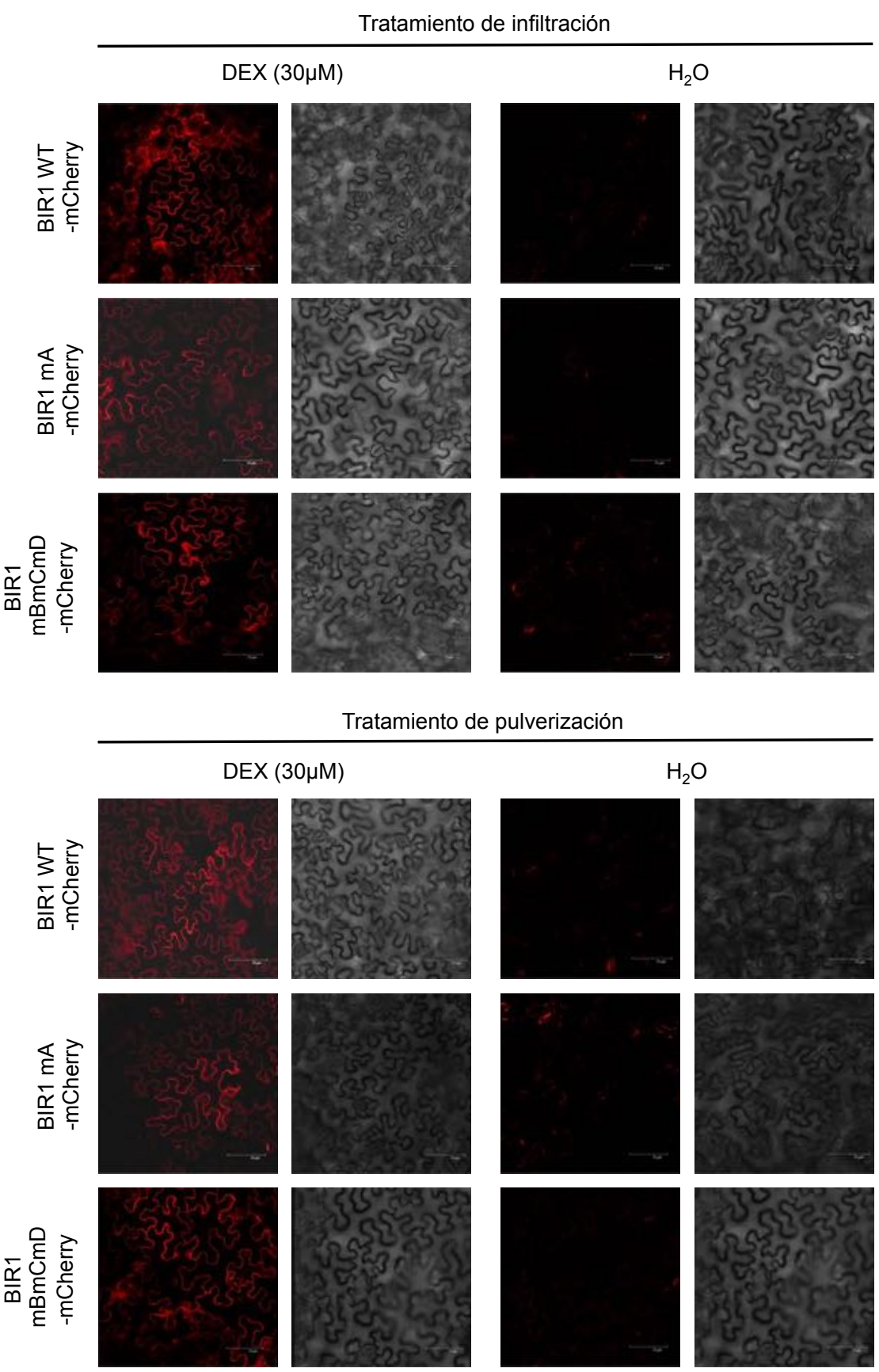

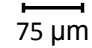

Figura 3.48. Expresión de proteína de fusión BIR1-mCherry bajo el promotor inducible con DEX en células epidérmicas de $N$. benthamiana. Las construcciones para las formas silvestre y mutada (mA y $\mathrm{mBmCmD}$ ) de BIR1 se agroinfiltraron a una $\mathrm{DO}_{600}$ final de 0,8 . Las imágenes se tomaron con un equipo de microscopía confocal Leica TCS SP2 AOBS con el objetivo de 40x de inmersión en aceite. El láser empleado fue de $561 \mathrm{~nm}$ DPSS para el fluoróforo mCherry. Las imágenes se procesaron con el programa ImageJ (NIH, versión $1.51 \mathrm{~h}$ ). 


\subsection{Caracterización de líneas sobreexpresoras de BIR1 en Arabidopsis}

Para cada una de las construcciones BIRl se seleccionaron al menos dos líneas homocigotas (T3) de inserción única para su posterior caracterización (líneas L5, L6 y L9 para BIR1 WT, L3 y L7 para BIR1 mBmCmD y L4 y L5 para BIR1 mA). Curiosamente, cuando las semillas transgénicas se germinaron en medio MS-MES en placa no observamos diferencias fenotípicas respecto al genotipo silvestre independientemente de la presencia de la hormona en el medio (Figura 3.49A) (Figura 3.49B). Tampoco observamos retraso en la germinación entre las semillas tratadas con DEX y las semillas control si bien el desarrollo fue ligeramente más lento en todas las plantas tratadas con DEX, incluidas las plantas de genotipo silvestre (Figura 3.49A) (Figura 3.49B). Ensayos Western blot empleando anticuerpos anti-mCherry mostraban que la proteína BIR1-mCherry transgénica se acumulaba significativamente en plantas tratadas con DEX pero no en las plantas control (Figura 3.49C). Mediante qRT-PCR observamos que las plantas transgénicas cultivadas en medio líquido (matraz) o sólido (placa) e inducidas con DEX producían niveles de transcritos de BIRI mayores que las plantas de fondo silvestre (Figura 3.49D). No obstante la expresión de BIRl variaba entre líneas. Las líneas silvestres L5 y L6 acumulaban aproximadamente 10 veces más transcritos de BIRl que las plantas no transgénicas mientras que la línea L9 acumulaba en torno a 25 veces más que el genotipo control (Figura 3.49D). Estos niveles de expresión difieren claramente de los niveles desproporcionados de acumulación de transcritos de BIRl detectados en plantas infectadas con las construcciones TRV-BIR1 WT. 
A
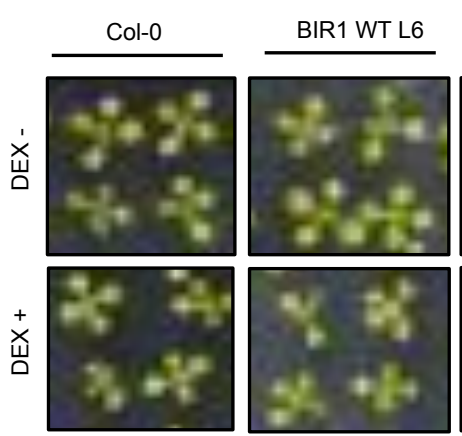

B

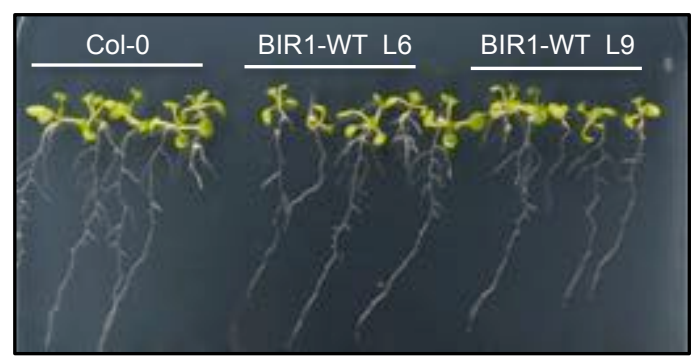

$\mathrm{D}$

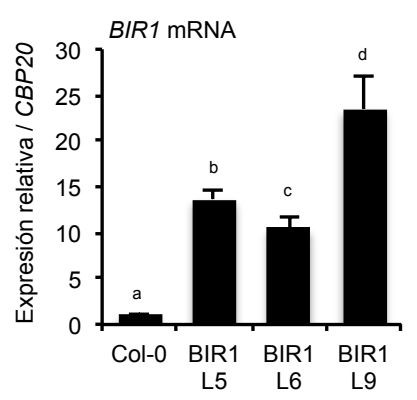

C
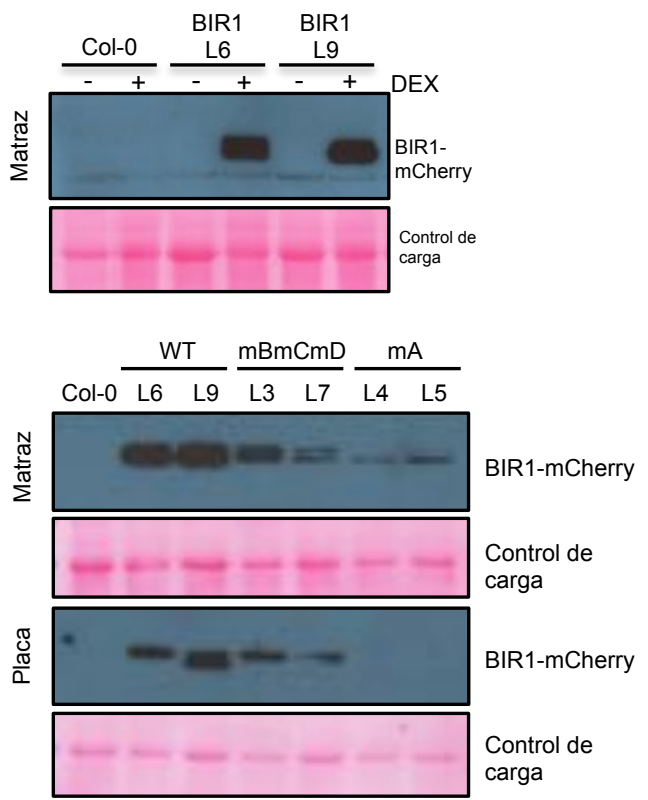

Figura 3.49. A) Plántulas de Arabidopsis silvestres (Col-0) y transgénicas BIR1 WT (L6 y L9) cultivadas en medio MS-MES en presencia y ausencia de DEX a los 7 días post-germinación. B) Plántulas de Arabidopsis silvestres (Col-0) y transgénicas BIR1 WT (L6 y L9) cultivadas en medio MS-MES tratadas con DEX a los 10 días post-germinación. C) Determinación, mediante Western blot, de los niveles de proteína BIR1-mCherry en Arabidopsis silvestres (Col-0) y transgénicas BIR1 WT (L6 y L9), BIR1 mBmCmD (L3 y L7) y BIR1 mA (L4 y L5) cultivadas en medio MS-MES líquido (matraz) o sólido (placa) en presencia $(+)$ y ausencia (-) de DEX. Se empleó un anticuerpo anti-mCherry. Las membranas teñidas con rojo Ponceau se muestran como control de carga. D) Acumulación relativa, mediante qRTPCR, de transcritos de BIR1 en Arabidopsis silvestres (Col-0) y en las líneas transgénicas BIR1 WT (L5, L6 y L9) cultivadas en medio MS-MES con DEX. Las distintas letras indican diferencias estadísticamente significativas $(P<0,001)$.

Dado que la pérdida de función en mutantes birl-1 se asocia con la expresión constitutiva de genes marcadores de defensa, quisimos investigar el efecto de la ganancia de función de BIRl sobre la expresión de genes de inmunidad en Arabidopsis. Para ello cultivamos plántulas de Arabidopsis en medio líquido durante 7 días en agitación a $70 \mathrm{rpm}$ tras los cuales añadimos DEX a una concentración de $30 \mu \mathrm{M}$. Los datos obtenidos por qRT-PCR mostraban una inducción significativa de PRl, PR4, $W R K Y 29$ y $P A D 3$ en la línea sobreexpresora L9, mientras que los valores de expresión relativa de estos marcadores en las líneas L5 y L6 eran, en general, más próximos a los 
de las plantas silvestres (Figura 3.50). Estos resultados sugieren que la activación de las respuestas de defensa es función del grado de acumulación de BIR1, de modo que solo las líneas con niveles altos de expresión de BIR1 experimentan cambios relevantes en la respuesta inmune.
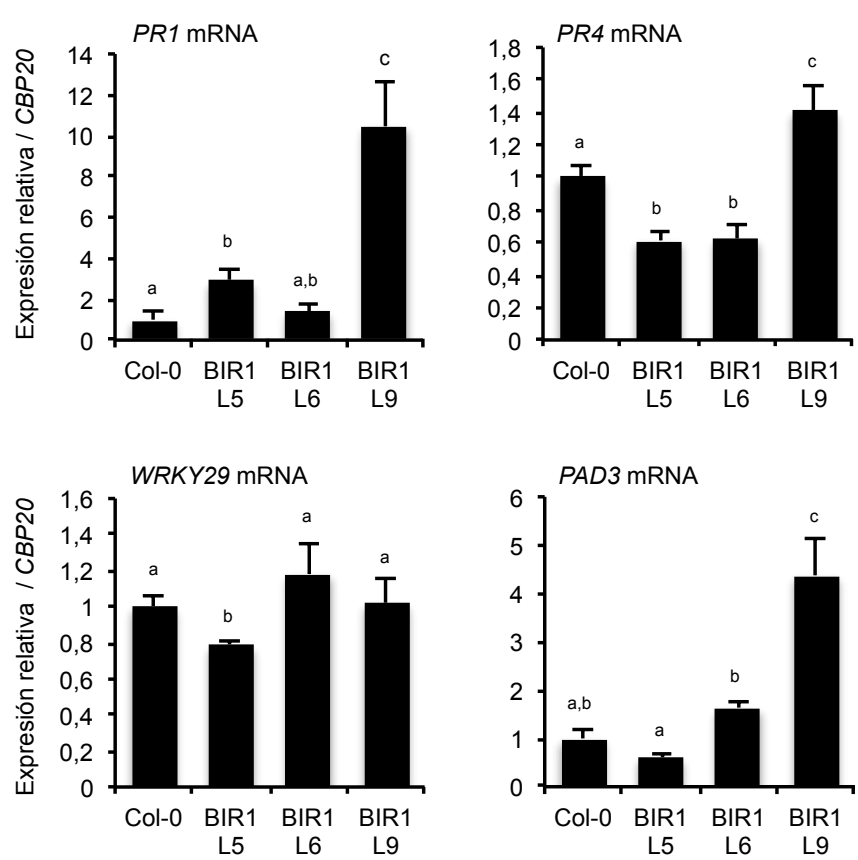

Figura 3.50. Acumulación relativa, mediante qRT-PCR, de transcritos de PR1, PR4, WRKY29 y PAD3. Las distintas letras indican diferencias estadísticamente significativas $(P<0,001)$. Las muestras analizadas proceden de Arabidopsis silvestres (Col-0) y de líneas transgénicas BIR1 WT (L5, L6 y L9) cultivadas en medio líquido en presencia $(+)$ o ausencia (-) de DEX.

Cuando analizamos el patrón de distribución de la proteína transgénica recombinante BIR1-mCherry por microscopia laser confocal en las líneas analizamos observamos una patrón coherente con la de proteínas de membrana, de acuerdo a lo observado anteriormente (Gao et al., 2009) (Figura 3.51). Como era esperable, este patrón era similar en plantas que expresaban tanto la forma nativa de BIRl como los dos mutantes analizados (mA y mBmCmD) (Figura 3.51). 

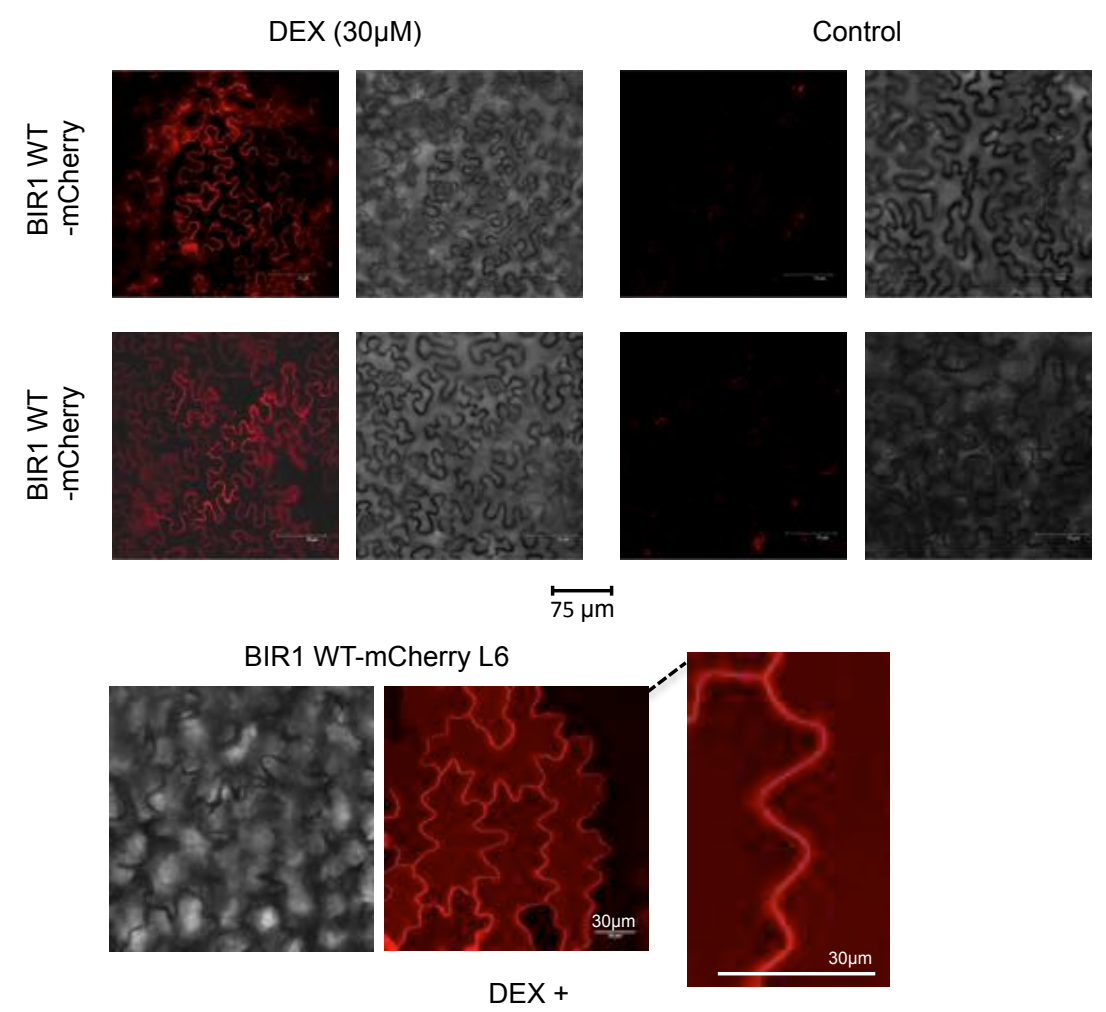

BIR1 mA-mCherry L4

BIR1 mBmCmD-mCherry L3
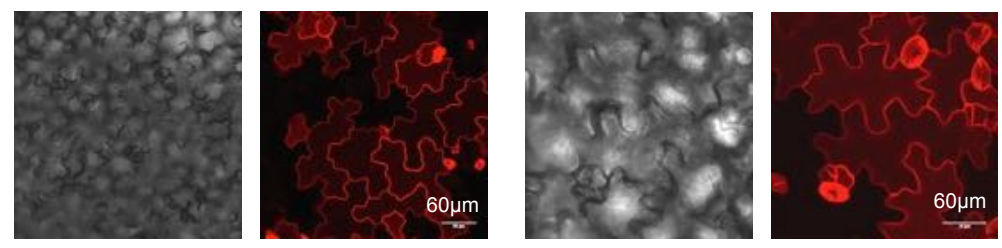

DEX +

DEX +

Figura 3.51. Expresión de proteína de fusión BIR1-mCherry bajo el promotor inducible con DEX en células epidérmicas de cotiledón de Arabidopsis para las líneas transgénicas BIR1 (WT, mA, mBmCmD) indicadas tratadas con DEX $30 \mu \mathrm{M}$ o con agua como control. Las imágenes se tomaron con un equipo de microscopía confocal Leica TCS SP2 AOBS con el objetivo de 40x de inmersión en aceite. El láser empleado fue de $561 \mathrm{~nm}$ DPSS para el fluoróforo mCherry. Las imágenes se procesaron con el programa ImageJ (NIH, versión 1.51h).

\subsection{Activación de la señalización inmune en plantas sobreexpresoras de BIRI}

La percepción del péptido bacteriano flagelina (flg22) por el receptor PRR FLAGELLIN SENSITIVE 2 (FLS2) activa las rutas de las MAP quinasas MEKKMKK4/5-MPK3/6 y MEKK1-MKK1/2-MPK4, que regulan positivamente la transcripción de genes de defensa a través de los factores de transcripción WRKY22/29 y WRKY25/33 (Asai et al., 2002; Nicaise et al., 2009). La pérdida de función de BIR1 en Arabidopsis compromete la activación de MAPK4 en respuesta a fgl22 (Gao et al., 2009). Esta vía de señalización regula negativamente la resistencia mediada por proteínas R en Arabidopsis (Gao et al., 2008; Macho and Zipfel, 2014). Para estudiar el efecto de la sobreexpresión de BIRl sobre la activación de MAP quinasas durante la 
respuesta inmune, tratamos las líneas para el transgén BIRl silvestre con el péptido flg22. Para ello cultivamos las plantas en medio líquido MS-MES con agitación y al cabo de una semana añadimos DEX a $30 \mu \mathrm{M}$ para inducir la síntesis de BIR1. Tras $24 \mathrm{~h}$ de inducción, añadimos fgl22 al medio a una concentración de $100 \mathrm{nM}$, mantuvimos en agitación y recogimos muestras a 10 y 20 min después del tratamiento. Como era de esperar, el tratamiento con flg22 activaba la acumulación de FRK1 en plantas silvestres y en menor mediada en las líneas L5 y L6 (Figura 3.52A) (Asai et al., 2002; He et al., 2006). Por el contrario, la línea L9 mostraba un sensibilidad extrema a flg22 como se deduce por la mayor acumulación de transcritos de FRK1 respecto a las tratadas con agua y al resto de genotipos analizados (Figura 3.52A). En consonancia con estos resultados, empleando ensayos Western blot con un anticuerpo específico frente a MAPK fosforiladas, pudimos detectar niveles más altos de activación de MPK3, MPK6 y MPK4/MPK11 en plantas de la línea L9 que en el control silvestre o que en las líneas transgénicas L5 y L6 (Figura 3.52B). No se observó acumulación de MAPK fosforiladas en las plantas tratadas con agua (Figura 3.52B). De estos resultados podemos inferir que la respuesta a flg22 es sensible a la sobreexpresión de BIRl.

A

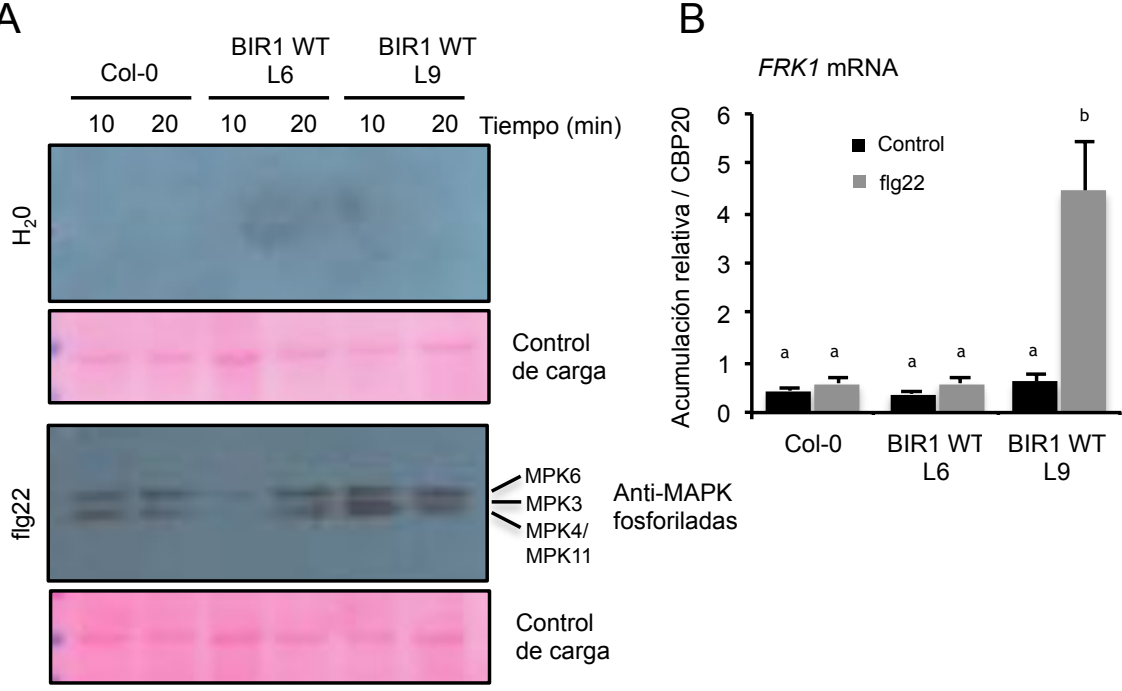

Figura 3.52. A) Acumulación relativa, mediante qRT-PCR, de transcritos de FRK1. Las distintas letras indican diferencias estadísticamente significativas $(P<0,001)$. B) Determinación, mediante Western blot, de los niveles de proteínas MAP kinasas fosforiladas empleando un anticuerpo anti-p44/42 MAPK. Las membranas teñidas con rojo Ponceau se muestran como control de carga. Las muestras analizadas proceden de plántulas de Arabidopsis de genotipo silvestre (Col-0) y de las líneas transgénicas BIR1 WT (L6 y L9) cultivadas en medio líquido en presencia de DEX. Las muestras se recolectaron a 10 y $20 \mathrm{~min}$ tras la aplicación de flg22 o de agua (control). 


\subsection{Estudio fenotípico de plantas transgénicas sobreexpresoras de BIRI}

Para determinar los efectos de la sobreexpresión de BIR1 en plantas cultivadas en sustrato sembramos semillas transgénicas de BIR1 WT de las líneas L6 y L9. A las tres semanas post-germinación iniciamos ciclos de pulverización con DEX a intervalos de $24 \mathrm{~h}$ durante una semana. Como controles del experimento se emplearon plantas no transgénicas así como plantas tratadas con agua. Entre seis y ocho días después de la primera aplicación de la hormona observamos la aparición de fenotipos extremos que recordaban a los observados en plantas infectadas que sobreexpresaban BIRl a través del vector viral TRV-BIR1 (Figura 3.53A). Aproximadamente el 75\% de las plantas de las líneas L6 y L9 tratadas con DEX mostraban alteraciones que afectaban en grado variable a la morfología y desarrollo de la planta (Figura 3.53B). Además las hojas de las líneas sobreexpresoras de BIRl exhibían muerte celular tras el tratamiento con DEX que no aparecía en las Arabidopsis silvestres o en las plantas transgénicas tratadas con agua (Figura 3.53C). Por el contrario, ni las plantas silvestres tratadas con DEX ni las líneas transgénicas tratadas con solución control (sin hormona) mostraron aberraciones en su fenotipo. Mediante ensayo Western blot pudimos verificar la acumulación significativa de proteína transgénica en aquellas plantas con fenotipos extremos (Figura 3.54A). Por el contrario, las plantas L6 y L9 que tras el tratamiento con la hormona se desarrollaban normalmente mostraban niveles indetectables de proteína transgénica (Figura 3.54A). Esto sugiere que la aparición de fenotipos morfológicos se encuentra ligada a la sobreacumulación de la proteína BIR1. Los resultados por qRT-PCR confirmaron que la sobreexpresión del transgén BIRl ocurría exclusivamente en las plantas tratadas con DEX y no en las plantas de genotipo silvestre o en las plantas transgénicas tratadas con agua (Figura 3.54B). El tratamiento periódico con la hormona facilitaba la acumulación de transcritos de BIRl en las líneas L6 y L9 a niveles de más dos ordenes de magnitud respecto a los obtenidos en cualquiera de los controles (Figura 3.54B). Los transcritos de BIRl se acumulaban en las líneas transgénicas L6 y L9 que presentaban un desarrollo normal al mismo nivel que en las plantas silvestres (Figura 3.54B). Estas observaciones contrastan con lo observado en plántulas transgénicas L6 y L9 cultivadas en medio MS, que mostraban fenotipos silvestres (Figura 3.49A y B) y niveles de acumulación de BIRl ligeramente por encima de las plantas control (Figura 3.50A). Nuestros nuevos datos apoyan la idea de que las alteraciones fenotípicas asociadas a la sobreexpresión de BIR1 son dependientes de dosis. Por otra parte, las manifestaciones fenotípicas observadas se deben a la sobreexpresión continuada de BIRl y no a su efecto combinado con la infección. 
A
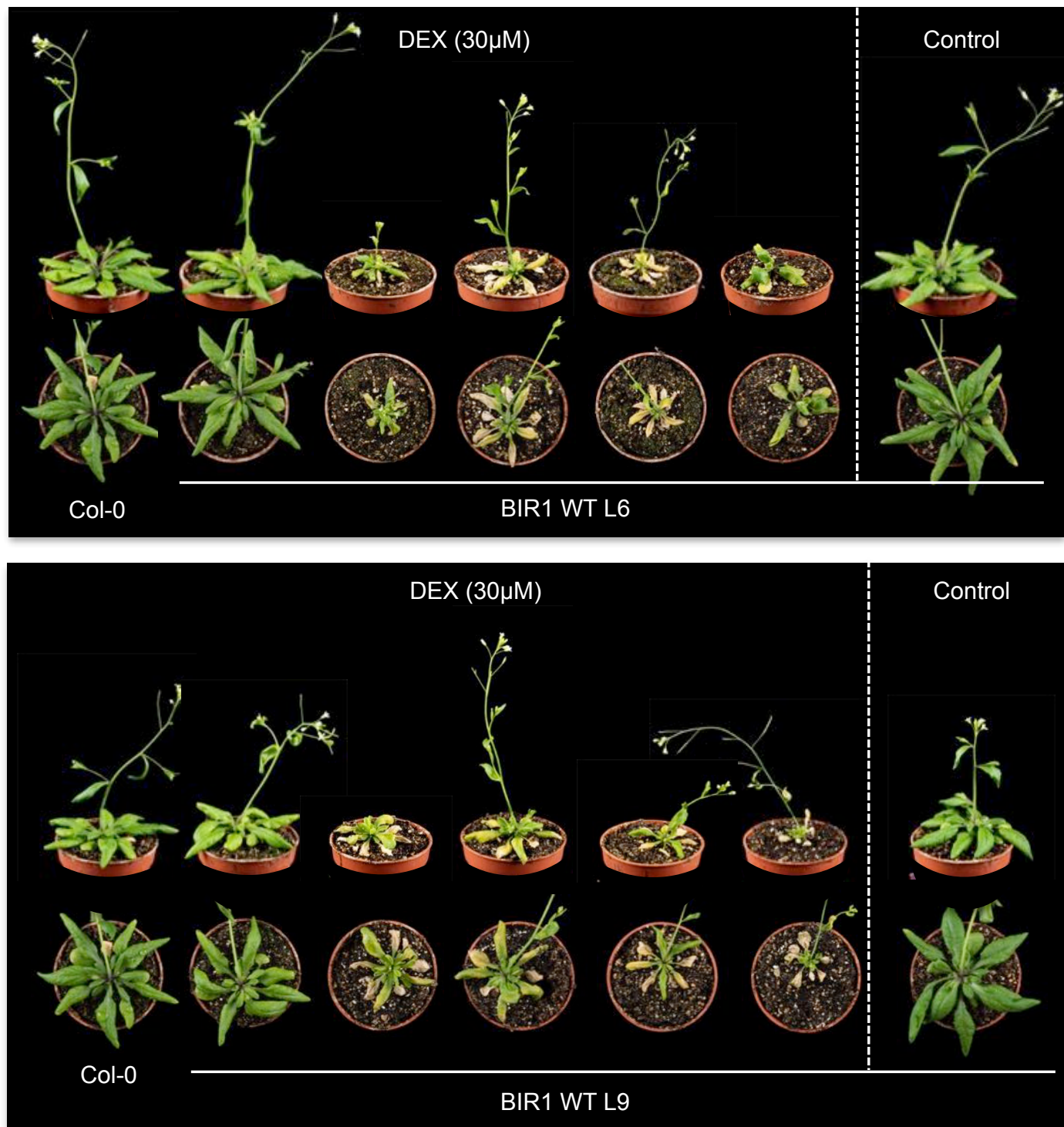

$\mathrm{B}$

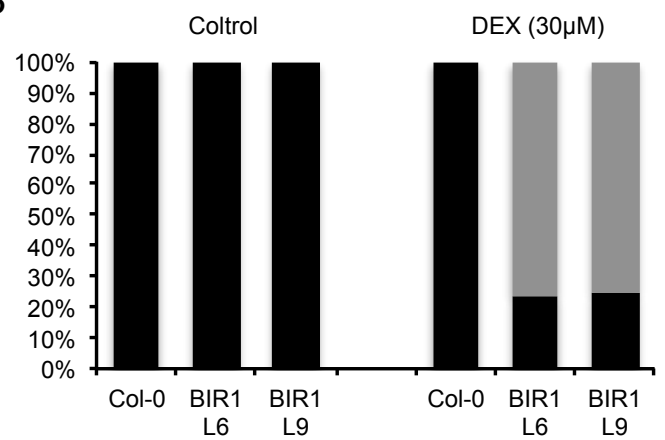

C

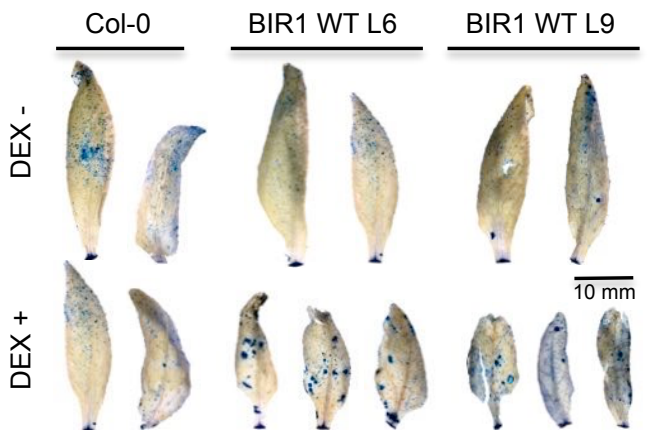

Figura 3.53. A) Fenotipos morfológicos en plantas silvestres de Arabidopsis (Col-0) y en las líneas transgénicas BIR1 WT (L6 y L9) a los 8 días de tratamiento con DEX. Las muestras control se trataron con agua. B) Distribución porcentual de fenotipos en plantas silvestres y en las líneas transgénicas BIR1 WT (L6 y L9) tras el tratamiento con DEX. C) Tinción de hojas de Arabidopsis silvestres (Col-0) y de las líneas transgénicas BIR1 WT (L6 y L9) con azul de tripano tratadas con o sin DEX. 
A continuación investigamos el estado inmunológico de las plantas sobreexpresoras empleando la qRT-PCR para cuantificar la acumulación de transcritos de genes de defensa. Los resultados del experimento demuestran que la sobreexpresión de BIRl en plantas con alteraciones fenotípicas se correlacionaba con altos niveles de transcritos para los genes PR1, PR4, PAD3 y WRK29 (Figura 3.54C). Por el contario, las plantas transgénicas L6 y L9 con desarrollo normal mostraban en general niveles de expresión para los genes de defensa comparables a los observados en plantas silvestres (Figura 3.54C). La regulación positiva de genes de defensa y de la muerte celular en las líneas L6 y L9 contradice la predicción de que la sobreexpresión de BIRl pudiera provocar la supresión inmunológica de la planta. Al contrario, las plantas sobreexpresoras muestran una activación constitutiva (en ausencia de patógenos) de muerte celular y de genes relacionados con diversas vías de resistencia en planta de forma similar a lo observado en mutantes de pérdida de función birl-1 (Gao et al., 2009). Por otra parte, nuestros resultados sugieren que la aparición de fenotipos morfológicos y la activación de las defensas de la planta depende del umbral de expresión de BIR1. 
A

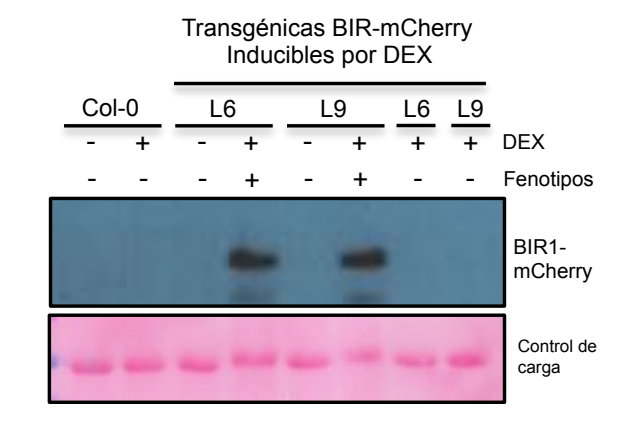

C
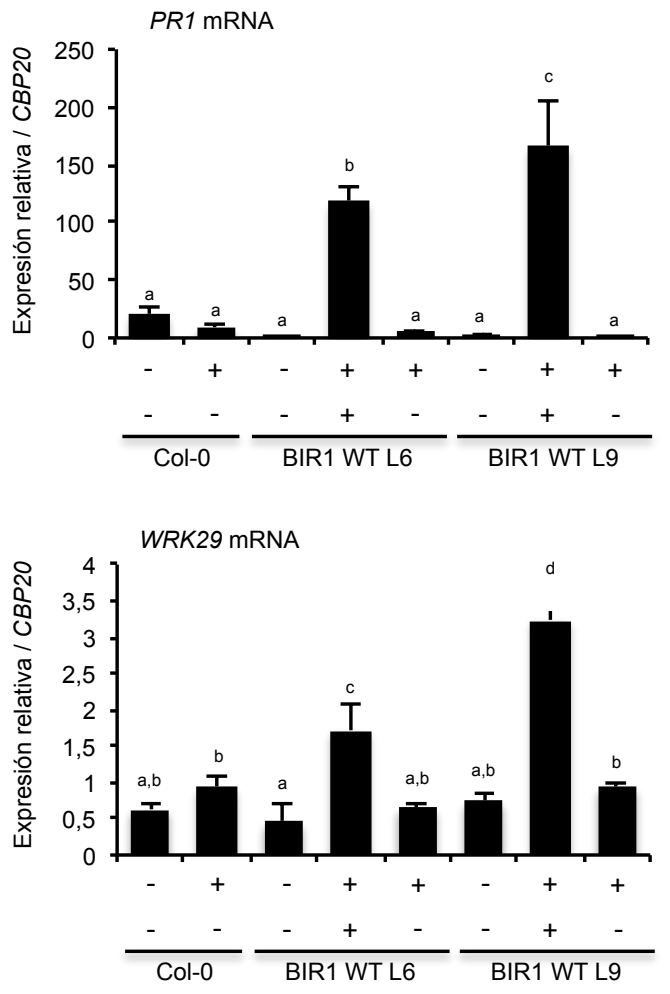

B
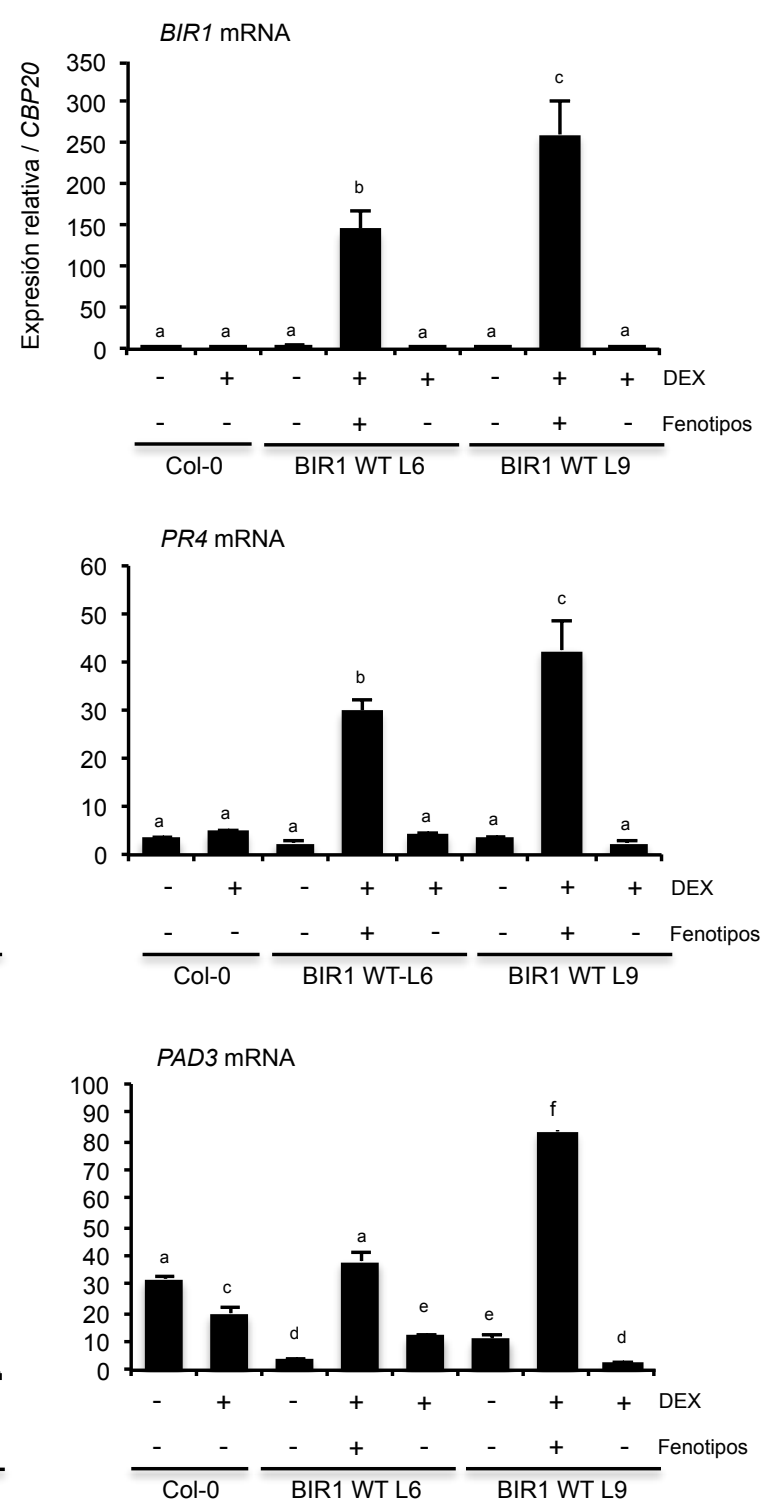

Figura 3.54. A) Determinación, mediante Western blot, de los niveles de proteína BIR1-mCherry, empleando anticuerpo anti-mCherry. La membrana teñida con rojo Ponceau se muestra como control de carga. B, C) Acumulación relativa, mediante qRT-PCR, de transcritos de BIRl (B) o de transcritos PRl, PR4, PAD3 y WRKY29 (C). Las muestras analizadas proceden de hojas de roseta de Arabidopsis de genotipo silvestre (Col-0) y de las líneas transgénicas BIR1 WT (L6 y L9) cultivadas en tierra. Se analizaron muestras tratadas con (+) o sin (-) DEX y muestras con fenotipos morfológicos (+) o fenotipo silvestre $(-)$. Las distintas letras indican diferencias estadísticamente significativas $(P<0,001)$. 


\subsection{Efecto de las dianas de degradación sobre la aparición de fenotipos morfológicos en plantas transgénicas sobreexpresoras de BIRI}

A continuación analizamos si las mutaciones sobre las dianas B, C o D afectaban a la aparición de fenotipos morfológicos aberrantes en plantas transgénicas sobreexpresoras de BIR1. Para ello cultivamos plantas de las líneas L3 y L7 para el transgén BIR1 mBmCmD. La líneas L6 y L9 de BIR1 WT y Arabidopsis silvestres se emplearon como controles. A las tres semanas post-germinación iniciamos ciclos de pulverización de DEX a intervalos de 24 h durante una semana. Como era de esperar, a los ocho días de comenzar el tratamiento observamos la aparición de fenotipos morfológicos en todas las líneas transgénicas tratadas con DEX (Figura 3.53A). Entre el $70 \%$ y el $80 \%$ de las plantas de las líneas L6 y L9 de BIR1 WT desarrollaron aberraciones fenotípicas mientras que en las líneas L3 y L7 de BIR1 mBmCmD el porcentaje de plantas con fenotipos morfológicos fue del 90\% (Figura 3.55A). Todas las plantas tratadas con solución control así como las Arabidopsis silvestres pulverizadas con DEX mostraron fenotipos normales. Mediante ensayo Western Blot verificamos que la proteína transgénica derivada de transcritos mutados se acumulaba a niveles similares a los de la proteína BIR1 derivada de transcritos silvestres (Figura 3.55B). Los resultados por qRT-PCR confirmaron que la acumulación de transcritos de BIRI en las dos líneas $\mathrm{mBmCmD}$ (L3 y L7) era equiparable al observado en la línea L6 de BIR1 WT, pero menor que el observado para la línea L9 (Figura 3.55C). Estos resultados sugieren que la alteración de los sitios de corte detectados en la región codificadora de BIR1 mediante análisis del degradoma no se asocia necesariamente con un mayor nivel de acumulación de transcritos o proteína BIR1 en Arabidopsis en la condiciones experimentales de nuestro ensayo. 
A

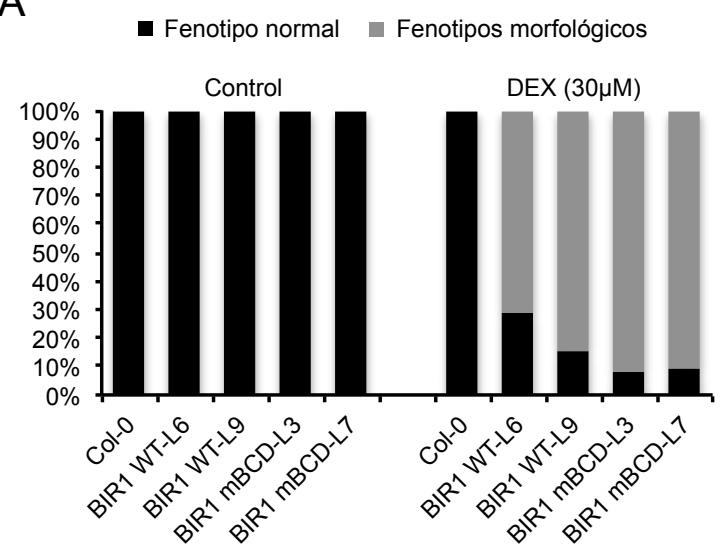

B
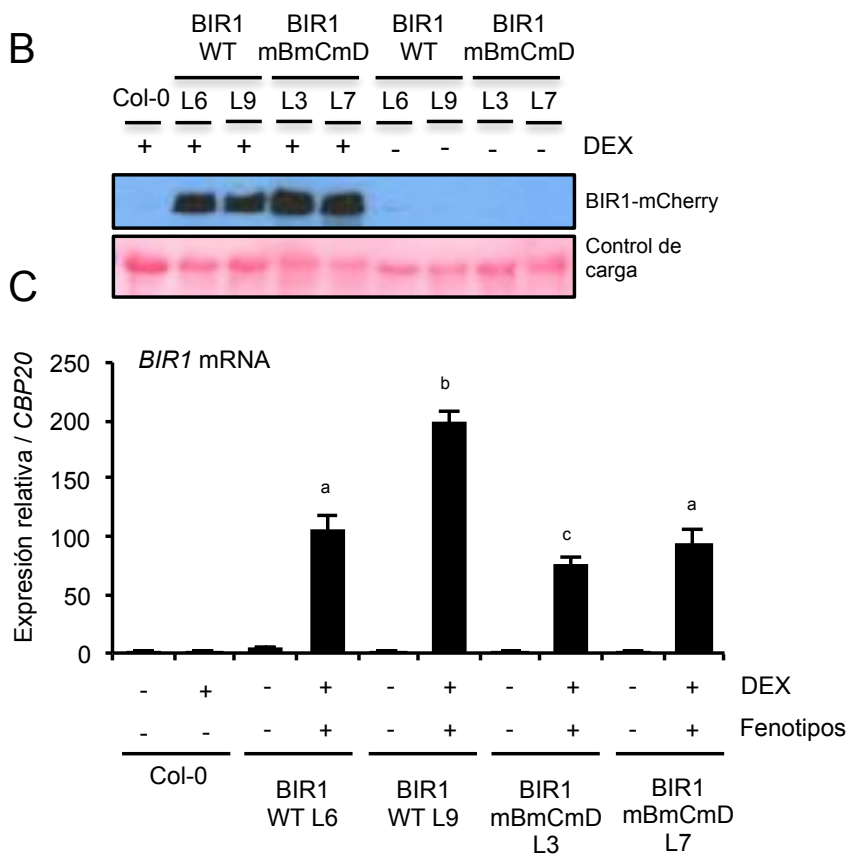

Figura 3.55. A) Distribución porcentual de fenotipos en plantas de genotipo silvestre (Col-0) y transgénicas BIR1 $\mathrm{mBmCmD}$ tras el tratamiento con DEX. Como control se analizaron las plantas tratadas con agua. B) Determinación, mediante Western blot, de los niveles de proteína BIR1mCherry empleando anticuerpo anti-mCherry. C) Acumulación relativa, mediante qRT-PCR, de transcritos de BIRI. Las muestras analizadas proceden de hojas de roseta de Arabidopsis de genotipo silvestre (Col-0) y de las líneas transgénicas BIR1 WT L6 y L9 y BIR1 mBmCmD L3 y L7 cultivadas en tierra. Se analizaron muestras tratadas con $(+)$ o sin (-) DEX y muestras con fenotipos aberrantes y $(+) \mathrm{o}$ fenotipo silvestre (-). Las distintas letras indican diferencias estadísticamente significativas $(P<0,01)$.

\subsection{Estudio de otros factores de susceptibilidad en Arabidopsis}

\subsubsection{Efecto de la infección de TRV sobre la expresión de genes inducibles por la oscuridad (DIN) en Arabidopsis}

Entre los genes cuya expresión se altera de forma significativa durante la infección por TRV pudimos identificar varios genes asociados a la senescencia catalogados como genes inducibles por la oscuridad ( $D I N$, del inglés dark inducible) (Fernandez-Calvino et al., 2014; Fernandez-Calvino et al., 2016). Los datos de expresión génica y las funciones predichas de los genes DIN de Arabidopsis deducidas de sus secuencias de aminoácidos se muestran en la Tabla 3.2. Para confirmar los datos de micromatrices reportados en (Fernandez-Calvino et al., 2014) relativos a la expresión de los genes DIN en plantas infectadas con TRV, realizamos qRT-PCR en un conjunto independiente de muestras. Los transcritos de DIN1 (At4g35770), DIN6 (At3g47340) y DIN11 
(At3g49620) eran particularmente abundantes en tejidos infectados con TRV en comparación con el control no infectado, y por ello fueron elegidos para su posterior análisis funcional (Figura 3.56).
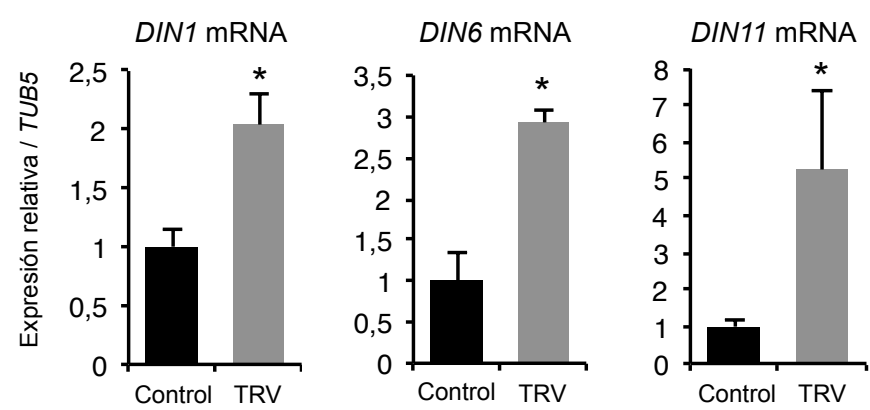

Figura 3.56. Acumulación relativa, mediante qRTPCR, de transcritos de los genes DIN1, DIN6 y DIN11 en hojas de roseta de Arabidopsis silvestres infectadas con TRV a 8 dpi. Los valores se relativizaron respecto a la muestra control inoculada con extracto de planta sana y las diferencias respecto a los valores de control se consideraron significativas con $P<0,001(*)$ o $P<0,05(\dagger)$.

\begin{tabular}{|c|c|c|c|c|c|}
\hline \multirow{2}{*}{ Gen } & \multirow{2}{*}{ AGI } & \multirow{2}{*}{ Descripción } & \multicolumn{3}{|c|}{ Fold change $\dagger$} \\
\hline & & & Hojas & Inflo. & Raíz \\
\hline DIN1 & At4g35770 & Senescence-associated gene 1 (SEN1) & $7,31^{* * *}$ & $4,75^{* * *}$ & $3,58^{* * *}$ \\
\hline DIN2 & At3g60140 & Beta-glucosidase 30, Senescence-associated gene 2 (SEN2) & 1,04 & $-0,98$ & 1,04 \\
\hline$D I N 3$ & At3g06850 & Dihydrolipoamide branched chain acyltransferase (BCE2) & 1,06 & $1,44^{*}$ & $1,86^{* * *}$ \\
\hline DIN4 & At3g13450 & Branched chain alpha-keto acid dehydrogenase E1 beta & $1,91^{* *}$ & $2,65^{* * *}$ & $1,5^{* *}$ \\
\hline DIN6 & At3g47340 & Glutamine-dependent asparagine synthase (ASN1) & $2,05^{* * *}$ & $3,011^{* * *}$ & $1,89^{* * * *}$ \\
\hline DIN9 & Atlg67070 & Phosphomannose isomerase 2 (PMI2) & $-0,96$ & $-0,97$ & 1,00 \\
\hline DIN10 & At5g20250 & Raffinose synthase 6 (RS6) & $-0,82$ & $4,5^{* * *}$ & $1,94^{* * *}$ \\
\hline DIN11 & At3g49620 & 2-oxoacid-dependent dioxygenase & $\mathrm{ND}+$ & ND & ND \\
\hline
\end{tabular}

$\dagger$ Los números en negrita indican diferencias significativas entre plantas control y plantas infectadas. $P$ valor $<$ $1 \times 10^{-12}(* * *), P<0.01(* *)$ ó $P<0.05(*)$ (Corrección de Bonferroni).

$\ddagger N D$, no detectado

Tabla 3.2. Cambios en la expression de genes inducibles por oscuridad DIN en hojas, inflorescencias y raices de Arabidopsis infectadas con TRV respecto a los controles sin infectar. Datos obtenidos de (Fernandez-Calvino et al., 2014) 


\subsubsection{Efecto de DIN11 sobre la susceptibilidad a TRV en Arabidopsis}

Para evaluar la contribución de DIN1, DIN6 y DIN11 a la infección por TRV, utilizamos líneas T-DNA de Arabidopsis de pérdida de función para estos genes con el fin de monitorizar la acumulación de virus. Los resultados obtenidos por qRT-PCR revelaban que TRV se acumulaba en mutantes $\operatorname{din} 1$ y $\operatorname{din} 6$ a los mismos niveles que en el fondo silvestre, lo que sugiere que ni DIN1 ni DIN6 desempeñan funciones relevantes en la susceptibilidad de Arabidopsis frente a TRV (Figura 3.57A). No fue posible sin embargo identificar líneas T-DNA para el gen DIN11. Por ello, para estudiar su contribución a la infección por TRV generamos plantas transgénicas de Arabidopsis que albergaban una construcción RNAi dirigida frente al gen DIN11 y seleccionamos dos líneas T3 homocigotas independientes (L10 y L21) para su análisis. En estas plantas, los niveles de transcripción de DIN11 se redujeron en más del $80 \%$ en comparación con los controles de genotipo silvestre, demostrando eficiencia en la inactivación del gen diana (Figura 3.57B). El silenciamiento de DIN11 en ambas líneas L10 y L21 se correlacionó con una reducción significativa en la acumulación de TRV en comparación con las plantas control a 5 y 8 dpi (Figura 3.57B). Curiosamente, los niveles de TRV medidos a 16 dpi fueron muy variables entre las distintas repeticiones independientes del experimento, lo que sugiere que el efecto de DIN11 sobre TRV pudiera restringirse a los primeros momentos de infección, en los que la proliferación del virus es particularmente dinámica. Para probar esta hipótesis, aislamos protoplastos de las hojas de la roseta de plantas silvestres y transgénicas RNAi de Arabidopsis y los sometimos a transfección con el vector infeccioso TRV1. Mediante qRT-PCR pudimos comprobar que la replicación viral estaba muy reducida en las líneas L10 y L21 a las 24 $\mathrm{h}$ después de la transfección (Figura 3.57C). Este resultado sugería que DIN11 pudiera representar un factor proviral clave para la correcta multiplicación de TRV en las etapas tempranas de la infección. 
A

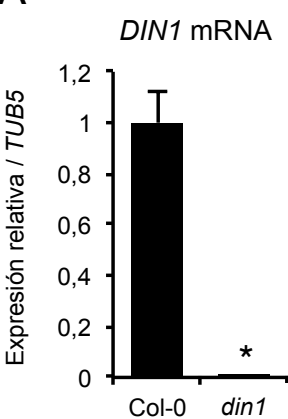

TRV RNA1

DIN6 mRNA

TRV RNA1
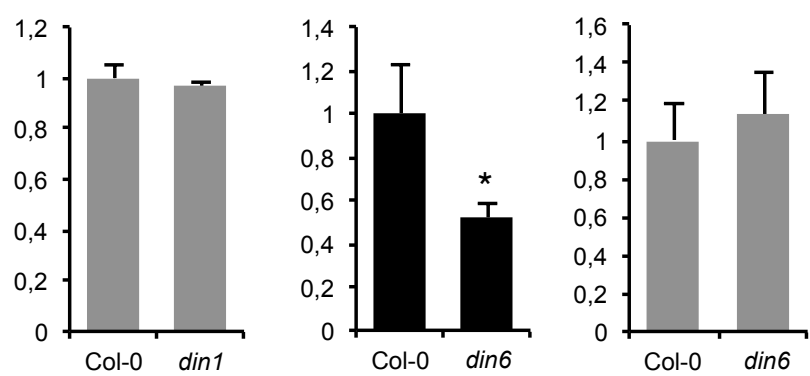

B

DIN11 mRNA

TRV RNA1 (5 dpi)

TRV RNA1 (8 dpi)
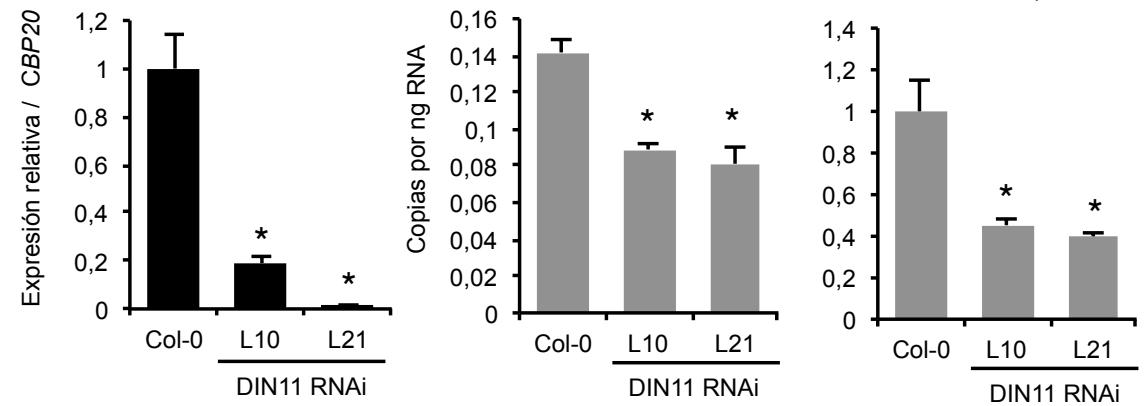

C

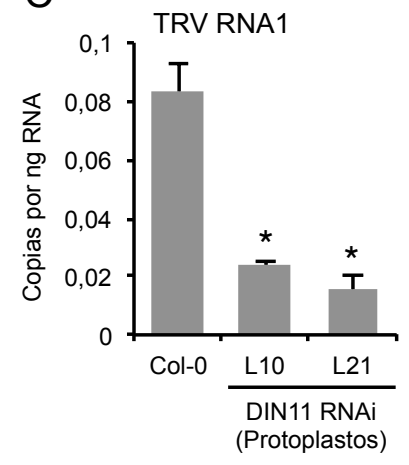

Figura 3.57. A) Acumulación, mediante qR-TPCR, de transcritos de DIN1 y DIN6 y de RNA1 genómico de TRV en hojas de Arabidopsis infectadas con TRV en plantas silvestres (Col-0) y en mutantes $\operatorname{din} 1$ y din6 a 8 dpi. B) Acumulación, mediante qRTPCR, de transcritos de DIN11 y del RNA genómico de TRV en hojas de Arabidopsis infectadas con TRV de plantas silvestres (Col-0) o en líneas RNAi-DIN11 (L10 y L21) a 5 (cuantificación absoluta) y 8 (cuantificación relativa) dpi. C) Acumulación, mediante qRTPCR del RNA genómico de TRV en protoplastos de Arabidopsis silvestres (Col-0) o en líneas RNAiDIN11 (L10 y L21) 24 h después de la transfección. Las diferencias se consideraron significativas con $P<0,001$ (*). 



\section{DISCUSIÓN}

\subsection{Activación de la respuesta inmune dependiente de BIR1 durante las infecciones virales}

El silenciamiento génico es un mecanismo clave en la regulación de la expresión de genes endógenos de la planta. En nuestro laboratorio hemos identificado y validado por métodos experimentales diversos genes de Arabidopsis cuyos RNA mensajeros presentan patrones de degradación consistentes con procesos de corte mediados por sRNAs. Algunos de estos transcritos de RNA se degradan de forma selectiva y exclusiva durante una infección viral, lo que apoya la idea de que los virus disparan una regulación post-transcripcional de transcritos endógenos (Cao et al., 2014). Entre los genes de respuesta a virus que son sometidos a degradación selectiva de sus RNAs mensajeros identificamos al represor inmune BIRl. Este gen se induce en respuesta a la infección con TRV y TuMV y su pérdida de función en el mutante birl-1 se asocia con resistencia antiviral, lo que sugiere $B I R l$ desempeña un papel importante durante la infección por virus. BIR1 es un regulador negativo de varias rutas de resistencia en las que BAK1 y SOBIR1 actúan de forma conjunta (Gao et al., 2009; Dominguez-Ferreras et al., 2015; Liu et al., 2016). Nuestros resultados indican que las infecciones virales inducen la expresión de SOBIR1, y que la mutación sobir1-12 causa un sutil descenso en la acumulación viral en Arabidopsis. En contraste, los transcritos de BAKl disminuyen en plantas infectadas con TRV y TuMV y los mutantes bak1-5, que están afectados en la respuesta PTI pero no en la señalización con brasinosteroides (Chinchilla et al., 2007; Heese et al., 2007; Schwessinger et al., 2011), son más susceptibles a la infección por TRV y otros virus (Korner et al., 2013). Esto confirma la existencia de una interacción dinámica entre los virus de plantas y la inmunidad basal que es controlada aguas arriba de las cascadas de señalización por el par BIR1/BAK1. Si bien BAK1, y probablemente SOBIR1, son determinantes en el control de la proliferación viral, su relación de interdependencia con BIR1 durante la respuesta de defensa antiviral necesita ser estudiada con mayor profundidad.

\subsection{BIR1, SA y resistencia antiviral frente a TRV}

Estudios previos mostraron que la mutación birl-1 se asocia con muerte celular, elevados niveles de SA y expresión constitutiva de genes de defensa dependientes de SA (Gao et al., 2009). Este hecho sugiere que el SA pudiera mediar una respuesta inmune frente a TRV en este mutante, de modo que los bajos niveles de acumulación de TRV en birl-1 podría ser una consecuencia de la inducción constitutiva de las defensas 
en este mutante. Sin embargo, las plantas con altos niveles de expresión de BIR1 no mostraban un fenotipo de resistencia antiviral frente a TRV, aun cuando estas plantas también mostraban muerte celular y activación constitutiva de genes de defensa. Este hecho evidencia que las vías de defensa que son comunes a la pérdida de función de BIR1 y a su sobreexpresión son irrelevantes en la estrategia defensiva de la planta frente a TRV.

En algunas interacciones compatibles entre plantas y virus se ha observado que el tratamiento exógeno con SA o la sobreexpresión de genes implicados en su biosíntesis son capaces de potenciar respuestas antivirales que pueden afectar a la replicación viral, a la acumulación de proteína de la cápsida y al movimiento sistémico del virus (Chivasa et al., 1997; Mayers et al., 2005; Ishihara et al., 2008; Qi et al., 2018). Sin embargo, nuestros experimentos demostraron que si bien el tratamiento de las plantas con SA sirvió para activar la expresión de genes de defensa, no fue suficiente para comprometer la acumulación de TRV. También se observó una resistencia a TRV en el doble mutante birl-1 sobir 1-1, en el cual tanto la muerte celular como la expresión constitutiva de genes de defensa dependientes de SA se encuentran inhibidas parcialmente por la mutación sobirl-1 (Gao et al., 2009). Estos resultados sugieren que la resistencia frente a TRV en el mutante bir1-1 no se debía a una activación constitutiva de las defensas mediadas por SA (Gao et al., 2009). Curiosamente, la pérdida de función de ICS1 en los mutantes sid2-2 se correlaciona con una disminución en la susceptibilidad viral, lo que sugiere que el SA pudiera actuar como factor proviral facilitando la acumulación de TRV en el tejido infectado. Por el contrario, NPR1 si pudiera desempeñar una función antiviral importante independiente de SA, como se deduce del fenotipo de hipersusceptibilidad en plantas npr 1-1. Más allá de nuestras observaciones, no podemos descartar la posibilidad de que otras vías de señalización inmune independientes de SA que se activan en plantas birl-1 (por ejemplo, rutas de resistencia mediadas por NDR1, PAD4 o EDS1) puedan participar activamente en el fenotipo antiviral en este mutante (Gao et al., 2009).

\subsection{SA y su función como activador de la expresión de BIR1 en infecciones virales}

El SA se ha descrito como molécula señalizadora en la regulación de la expresión y función de varios (co)receptores inmunes relacionados con PAMPs (Loake and Grant, 2007; Tateda et al., 2014). En esta tesis hemos demostrado que la activación transcripcional de $B I R I$ es dependiente de SA, y que probablemente la inducción de $B I R l$ en respuesta a la infección es una consecuencia de los niveles elevados de $\mathrm{SA}$ en los tejidos infectados. Esta afirmación se fundamenta en el hecho de que la activación de BIRl asociada al virus está inhibida parcialmente en mutantes defectivos en la 
biogénesis (sid2-2) y señalización (npr 1-1) del SA. De ello se deduce además que la activación por SA de BIRl en plantas infectadas es dependiente del coregulador transcripcional NPR1 (Wu et al., 2012). El análisis de la secuencia de la región promotora de BIRl reveló varios motivos de unión de factores de transcripción (FT) relacionados con rutas de señalización de defensa inducidas por SA y por otras hormonas como ácido jasmónico (JA) y etileno (ET). Al igual que lo observado con el SA, el análisis del contenido de hormonas mediante GC-TOF-MS reveló un incremento gradual de JA en tejidos infectados a lo largo del tiempo (Figura 4.1). Esto sugiere que el control transcripcional de $B I R I$ durante la respuesta antiviral pudiera estar mediado por factores de transcripción como WRKYs, bHLHs, AP2/ERF y EIN3. Curiosamente, observamos que el gen RAP2.4 que contiene AP2 se encontraba inducido significativamente durante la infección por TRV. De igual forma, observamos lugares de unión para MYB y FT con homeodominio en la región promotora de BIRl que podrían ser reconocidos por los FT ATMYB15, ATMYB77 (MYB FT) y EDT1.

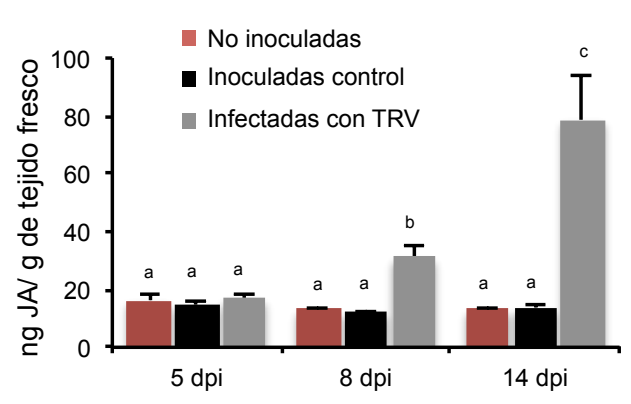

\begin{abstract}
Figura 4.1. Acumulación de la hormona JA en hojas de roseta de Arabidopsis silvestres (Col-0) no inoculadas, inoculadas con extracto de planta sana (control) o con TRV a los 5, 8 y 14 dpi. Las distintas letras indican diferencias estadísticamente significativas, $P<0,001$.
\end{abstract}

\title{
4.4. EI silenciamiento génico como elemento clave en la regulación de BIRI
}

La función de BIRl como represor de varias rutas de señalización inmune es crítica para entender cómo las plantas evitan la activación constitutiva de las defensas y de las respuestas tipo PTI y ETI en ausencia de patógenos (Gao et al., 2009). A pesar de su función esencial en la homeostasis de célula, los mecanismos que regulaban BIR1 eran desconocidos en el momento de iniciar esta tesis. Nuestros experimentos demuestran que el mecanismo RdDM es clave en la regulación transcripcional de BIRl en condiciones normales de crecimiento y desarrollo. En Arabidopsis, los siRNAs de 24 nts dirigen la metilación del DNA en regiones homólogas del genoma (Matzke and Mosher, 2014). La acumulación de siRNAs que encontramos aguas arriba del punto de inicio de transcripción de $B I R 1$ se correlaciona con una amplia metilación de citosinas en esta región. Asimismo, la transcripción de BIRl se induce en los mutantes afectados en la actividad de la metiltransferasa DRM2, requerida para el establecimiento inicial de la metilación de las citosinas en todos los contextos de secuencia, así como del mantenimiento de la metilación asimétrica CHH (Cao and Jacobsen, 2002; Cao et al., 
2003). También encontramos un incremento en la acumulación de transcritos de BIRI en los mutantes nrpel y ago4, en los cuales la metilación del promotor de BIRl se reducía drásticamente. Además, comprobamos que Pol V transcribía aguas arriba de $B I R 1$ ya que pudimos detectar los transcritos de esta región y que estos desaparecían en los mutantes nrpel. De este modo, nuestros resultados encajan en el modelo de metilación RdDM y sugieren que los transcritos de Pol V unen los complejos siRNAAGO4 y guían a DRM2 en la metilación del promotor de BIRl (Wierzbicki et al., 2009; Lahmy et al., 2016). Cuando analizamos los niveles de expresión de BIRl en mutantes defectivos en la biogénesis de siRNAs primarios y secundarios, observamos en alguna de las réplicas biológicas analizadas un cierto incremento en la acumulación de transcritos de BIRI respecto al fondo silvestre. Estos datos sugerían que, en ausencia de patógeno y en determinadas circunstancias, el silenciamiento post-transcripcional podría ajustar de forma condicional los niveles de transcritos de BIRl y complementar los efectos de la regulación transcripcional dependiente de RdDM.

\subsection{Silenciamiento génico y regulación de BIR1 durante la infección viral}

Varios estudios han demostrado que la metilación del DNA reprime la expresión de ciertos genes de resistencia en ausencia de patógenos, mientras que la infección por patógenos microbianos se asocia con proceso dinámico de desmetilación que favorece su inducción (Dowen et al., 2012; Yu et al., 2013). Curiosamente nuestros experimentos demuestran que la inducción transcripcional de BIRl en respuesta a la infección por TRV es independiente del estado de metilación de su promotor. Esta afirmación se sustenta en tres observaciones: 1) la infección por TRV no afectaba a la producción de siRNAs de 24 nts en la región promotora de $B I R 1,2)$ los niveles de citosinas metiladas en el promotor de $B I R l$ en plantas infectadas eran comparables a lo observado en plantas control, y 3) la inducción de BIRl en presencia de TRV era independiente del estado de metilación de la planta. De la misma manera, evidencias similares demuestran que el SA activa la transcripción de BIRl durante la infección sin interferir con su regulación epigenética.

Mientras que el silenciamiento transcripcional parece representar un mecanismo basal constitutivo de regulación de $B I R 1$, el silenciamiento post-transcripcional adquiere una dimensión esencial en plantas infectadas ya que refuerza la acción del silenciamiento epigenético eliminando el exceso de transcritos producidos en respuesta al virus. De esta manera, la infección se asocia con la producción de siRNAs de cadena positiva y negativa en la región codificadora de BIRl y con la sobreacumulación de transcritos de $B I R l$ en plantas mutantes con defectos genéticos en la ruta de biosíntesis y función de siRNAs. La formación de siRNAs de BIRl en plantas infectadas con TRV 
o TuMV recuerda a los vasiRNAs asociados a virus descritos con anterioridad (Cao et al., 2014). Los vasiRNAs se generan desde múltiples genes del huésped durante la activación del silenciamiento antiviral (Cao et al., 2014). Se piensa que estos vasiRNAs pueden dirigir el silenciamiento de los genes de los que proceden, al igual que los siRNAs de BIRl podrían guiar el autosilenciamiento de los transcritos de BIRl. Los requerimientos genéticos para la biogénesis de siRNA procedentes de BIRl así como su función parecen diferir sin embargo de la ruta genética de los vasiRNAs, la cual depende principalmente de DCL4, RDR1 y AGO2 (Cao et al., 2014). Según nuestros datos es posible que a la biogénesis y función de vasiRNA durante la infección contribuyan varias rutas complementarias que incluyan RDR6 y AGO1. Curiosamente, la supresión del silenciamiento mediada por TRV no fue suficiente para evitar el silenciamiento de BIRI (Martinez-Priego et al., 2008; Fernandez-Calvino et al., 2016b).

\subsection{Procesamiento endonucleolítico de transcritos de BIRI}

El silenciamiento post-transcripcional opera por medio del procesamiento endonucleolítico de los RNA mensajeros y de la inhibición de su traducción. Es esperable por tanto que el silencimiento de BIRl genere perfiles de degradación diferentes en plantas sanas e infectadas. De acuerdo con esta premisa, el análisis del degradoma mostraba un incremento sustancial de RNAs degradados de BIRI en plantas infectadas respecto a las plantas control y definía varios sitios o secuencias de corte preferente a lo largo del RNA mensajero (referidos como A, B, C y D). En nuestros ensayos de expresión transitoria en plantas de $N$. benthamiana observamos que las formas derivadas de $B I R 1$ que portaban mutaciones simultáneas en las posiciones $\mathrm{B}, \mathrm{C}$ y $\mathrm{D}$ producían transcritos y proteínas que eran más estables que los derivados del gen $B I R 1$ silvestre. Esto sugiere que dichas secuencias de corte parece ser relevantes en la regulación post-transcripcional de BIRl. No obstante, el mecanismo molecular que subyace a dicha regulación es desconocido.

Si los siRNAs derivados de BIRl regulan en cis la degradación de sus RNAs mensajeros, el predominio de ciertos sitios de corte en el degradoma podría estar reflejando preferencias de secuencia de los complejos AGO, como aquellas relacionadas con las características estructurales del RNA diana (Overhoff et al., 2005). En este supuesto, las mutaciones en el RNA diana podrían alterar su estructura secundaria y entorpecer el acceso y la actividad de los complejos AGO-siRNA. No obstante, otros escenarios de regulación son posibles. Por ejemplo, los cortes del RNA mensajero de BIRl se concentran cerca del extremo 3' de la región codificadora, a 13 (sitio C) y 40 (sitio B) nts aguas arriba del codón de terminación. Este patrón se asemeja a la acumulación de intermediarios truncados de RNA debido a la interrupción ribosómica 
durante la terminación de la traducción asociada al proceso de decaimiento cotraduccional de RNA mensajero (en inglés co-translational mRNA decay) (Hou et al., 2016; Yu et al., 2016). Los sitios B y C se encuentran separados por 28 nts y la huella de un ribosoma ocupa de 28 a 29 nts sobre el RNA mensajero (Pelechano et al., 2015). Esto sugiere que los sitios B y C se encuentran separados por una distancia igual al fragmento cubierto por un ribosoma. Es por lo tanto posible que el ribosoma pausado en el codón de terminación proteja al RNA mensajero de BIRl de la degradación cotraduccional en sentido 5'-3' y permita la acumulación de intermediarios de degradación cuyos extremos $5^{\prime}$ corresponderían con las posiciones B y C. Esta hipótesis sin embargo no explica cómo mutaciones sinónimas dentro de estos puntos de corte incrementan la estabilidad del RNA mensajero. Además, no podemos excluir explicaciones alternativas como la actividad de otras endonucleasas específicas de secuencia en el tejido infectado.

\subsection{Caracterización del locus MIR5658 y su efecto sobre la regulación post- transcripcional de $B I R 1$}

Cuando comparamos las lecturas del degradoma de BIRl con las secuencias de miRNAs de Arabidopsis depositadas en miRBase, identificamos una alta complementariedad de bases entre el miR5658 y la región 5' UTR del transcrito de BIRl donde se ubica el sitio de corte A. Es más, este sitio de corte se localizaba en posición 11 desde el extremo 5' del miR5658 en la región de complementariedad con el $B I R 1$, de acuerdo a lo esperado si el miRNA guiara el procesamiento en esta posición. Curiosamente pudimos identificar sitios de cortes secundarios en secuencias flanqueantes a la secuencia de corte A que además presentaban un alto grado de complementariedad con el miR5658. Estos resultados sugerían que el miR5658 pudiera ser responsable de la digestión del RNA mensajero de BIRl en cualquiera de estas posiciones. Sin embargo, aunque el miR5658 se ha anotado en la miRBase como un nuevo miRNA, nuestros resultados cuestionan que se trate de un auténtico miRNA de acuerdo a los criterios definidos para los miRNAs de plantas (Meyers et al., 2008). La predicción de la estructura secundaria del RNA precursor que contiene el miR5658 lo sitúa en un tallo de la horquilla con alto grado de complementariedad $(\Delta \mathrm{G}$ inicial $=$ $36.90 \mathrm{kcal} / \mathrm{mol}$ ). Sin embargo, el miR5658 apenas es detectable en bases de datos generadas empleando tecnologías de ultrasecuenciación y no hay confirmación de la existencia de su cadena "estrella" (del inglés star strand) (Arabidopsis Next-Gen Sequence

DBs; https://mpss.danforthcenter.org/web/php/pages/mirAbundances.php?SITE=at_sRNA). De la misma forma, no ha sido posible detectar este miRNA ni en genotecas de sRNAs generadas en nuestro laboratorio ni en el tejido vegetal empleando diversas técnicas 
analíticas de gran sensibilidad. Tampoco fue posible detectar el miR5658 en parches de hoja de $N$. benthamiana que expresaban distintas versiones de la secuencia precursora del locus MIR5658. Por el contrario, la secuenciación de sRNAs en plantas infectadas con virus confirmó la producción de siRNAs de polaridad positiva y negativa en otras posiciones dentro del gen At4g39838 que contiene el miR5658. Este hecho parece indicar que el miR5658 no es un miRNA canónico resultante del procesamiento de un RNA precursor estructurado sino que forma parte de una población más grande de siRNAs resultantes del procesamiento de intermediarios de dsRNA formados en este locus. Estos intermediarios pudieran ser el resultado de la transcripción convergente de At4g39840 y At4g39838.

Para nuestra sorpresa, descubrimos que los RNA precursores que contienen el miR5658 comprometen la expresión de BIRl en ensayos de expresión transitoria en $N$. benthamiana. Este efecto resultó ser específico de secuencia y requerir tanto la región 5'UTR de BIRl como su secuencia codificadora. Desconocemos las bases moleculares de esta regulación pero existen varias posibilidades. En primer lugar, es posible que miRNAs similares a miR5658 u otras especies de RNAs no codificantes más largos derivados de la región superpuesta del par NAT At4g39840/At4g39838 interaccionen funcionalmente con cualquiera de los sitios de unión del miR5658 localizados en la región 5'UTR y estimulen la producción secundaria de siRNAs aguas abajo de los sitios de corte de BIRl (Howell et al., 2007; Katiyar-Agarwal et al., 2007). También puede ocurrir que siRNAs secundarios (por ejemplo, vasiRNAs) producidos en diferentes loci en respuesta a las infecciones virales actúen en trans y dirijan el corte de los transcritos de BIR1. A este respecto, pudimos identificar en nuestras genotecas de sRNAs un siRNA que compartía complementariedad de secuencia casi perfecta con el sitio de corte A en la región 5'UTR de BIRl (Figura 4.2A). Este siRNA muestra una identidad de secuencia del 100\% con cinco genes de Arabidopsis (Figura 4.2B), de los cuales el gen Basic Region/Leucine zipper motif 60 (bZIP60, Atlg42990) produce grandes cantidades de siRNAs en respuesta a la infección con TRV o TuMV (Figura 4.2B y C). 
A

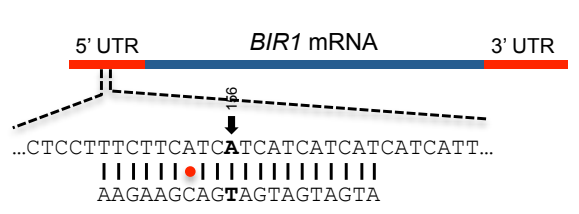

C
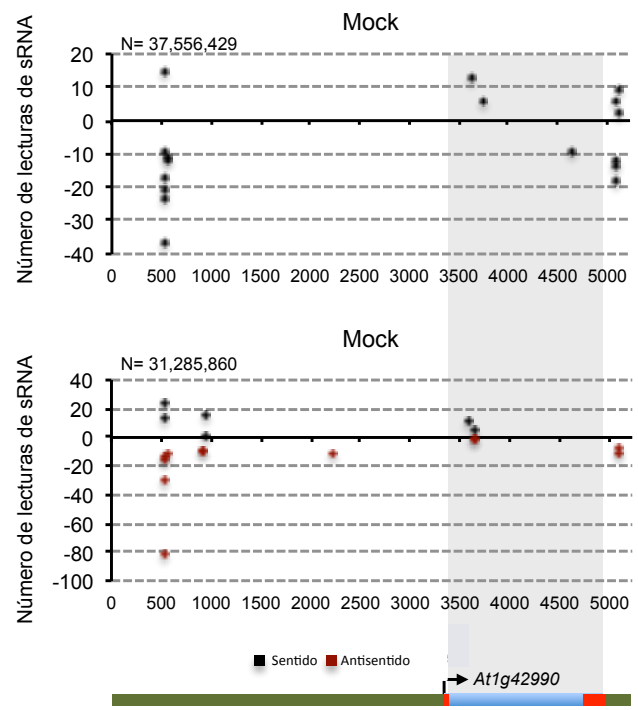

B

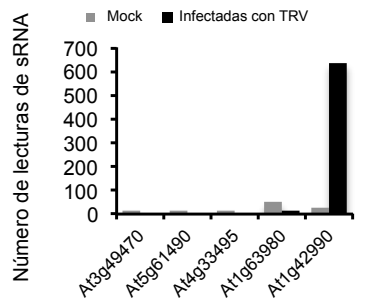

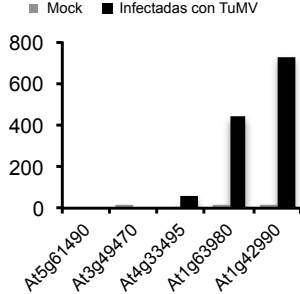

Infectadas con TRV

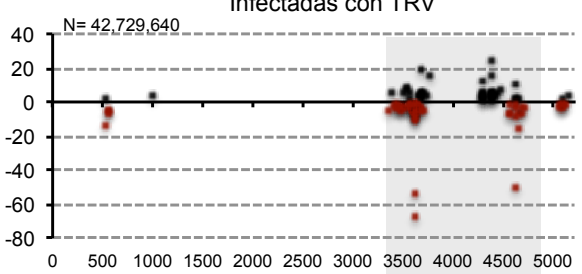

Infectadas con TuMV

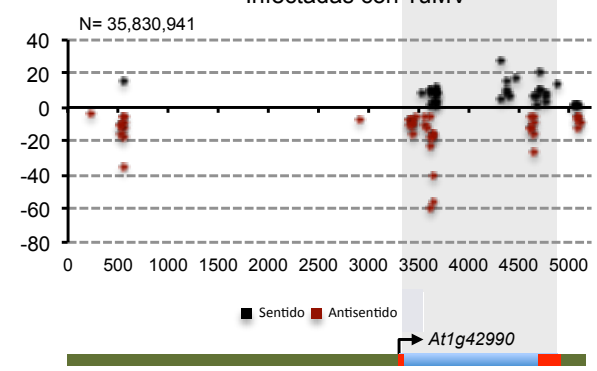

Figura 4.2. Identificación de siRNAs con que potencial para interaccionar con $B I R l$ en Arabidopsis. A) Representación esquemática de un siRNA candidato que interacciona con BIR1 en la región que contiene el sitio de corte A definido por degradoma. El siRNA se identificó a través de secuenciación de sRNA. Los desapareamientos se muestran como puntos rojos. Una flecha indica el principal punto de corte A en la posición 156. B) Identificación de los genes de Arabidopsis de los que podría derivarse el siRNA candidato ya producción de siRNAs asociados a virus en los loci identificados en plantas inoculadas con los virus TRV (izquierda) y TuMV (derecha) y con extracto de planta sana (control). C) Distribución de los siRNA derivados de At1g42990 en hojas de roseta de Arabidopsis inoculadas con extracto de planta sana (control) o infectadas con TRV (arriba) o TuMV (abajo). La región sombreada indica la posición del locus Atlg42990. Se representan las especies de siRNA sentido (puntos negros) y antisentido (puntos rojos) como valores positivos y negrativos en el eje $\mathrm{Y}$, respectivamente. $\mathrm{N}$ indica el número total de lecturas de secuenciación filtradas.

\subsection{Relevancia biológica de la regulación de BIRI}

La sobreexpresión de BIRl provoca fenotipos autoinmunes similares a los observados en los mutantes birl-1 y que se manifiestan en forma de muerte celular, inducción constitutiva de las defensas y la consecuente aparición de alteraciones morfológicas de diversa gravedad. Parece por tanto evidente que una regulación bien calibrada de los niveles de BIR1 resulta indispensable para que pueda ejercer un control adecuado de la respuesta inmune. De nuestros resultados no es posible inferir el mecanismo preciso responsable de este fenotipo autoinmune pero ya que BIR1 es una RLK activa, su sobreexpresión podría interferir con la función de otras RLKs implicadas en programas de defensa o desarrollo. Por otra parte, la sobreproducción de 
BIR1 podría bien afectar a la regulación negativa de sus parejas correceptoras o promover interacciones inapropiadas con otras proteínas (co)receptoras que resulte en la activación de la resistencia (Prelich, 2012; Rodriguez et al., 2016). Por ejemplo, altas dosis de BIR1 podrían bloquear la función de su interactor BAK1 en regulación de la muerte celular dependiente de SOBIR1 (Liu et al., 2016).

El análisis de expresión de BIRl en mutantes de Arabidopsis con defectos genéticos en la metilación del DNA o en la biogénesis y función de siRNAs revelaba incrementos significativos en los niveles de acumulación de transcritos de BIR1 que sin embargo no se asociaban con fenotipos autoinmunes. Este decubrimiento tiene dos importantes implicaciones. En primer lugar se podría inferir que el silenciamiento por RNA desempeña un papel secundario en el control de la expresión de BIRl y que deben existir otros mecanismos reguladores, desconocidos aun, que mantengan BIRl por debajo de niveles perjudiciales para la eficacia biológica de la planta. Sin embargo, la pérdida de función de uno o varios genes no implica necesariamente la inhibición completa de la ruta de silenciamiento (Bouche et al., 2006). Es más, los mutantes empleados en este estudio estaban afectados bien en la ruta RdDM o en el silenciamiento post-transcripcional pero no en ambas. Por tanto, es probable que en cualquiera de estos mutantes, aun en condiciones subóptimas, el silenciamiento pueda ejercer un control efectivo sobre BIRl evitando que alcance niveles de expresión deletereos. La segunda implicación es que los fenotipos aberrantes asociados a la inducción de BIRl son probablemente dependientes de dósis. En nuestros experimentos, las plantas transgénicas sobreexpresoras de BIRl con aberraciones en su desarrollo producían transcritos de $B I R l$ más de dos órdenes de magnitud por encima de lo observado en las plantas control. Por el contrario, las plántulas de esas mismas líneas transgénicas presentaban un desarrollo normal cuando se cultivaban en placas con medio MS-DEX. Curiosamente estas plantas acumulaban entre 10 y 20 veces más transcritos de BIRl que los fondos silvestres en estas condiciones experimentales. Esto supone una expresion de BIR1 al menos un orden de magnitud inferior a la de las plantas cultivadas en sustrato. Además, como era de esperar, la acumulación de genes de defensa no se veía alterada de forma significativa en las plantas transgénicas (líneas 5 y 6) germinadas en placas. Tan sólo la línea 9 producía $B I R 1$ a unos niveles que inducían un incremento moderado de expresión de $P R 1, P R 4$ y $P A D 3$, pero que resultaba insuficiente para perturbar el desarrollo y la morfología de la planta. De forma similar, un mecanismo dependiente de dosis explicaría por qué los mutantes de silenciamiento, en los que el incremento de BIRl es también discreto, muestran fenotipos normales. Excepcionalmente, el triple mutante $d d c$ presenta defectos en su desarrollo (Chan et al., 2006) y activación constitutiva de genes de defensa (Dowen et al., 2012), pero este fenotipo es probablemente el resultado de la desregulación 
transcripcional de genes de desarrollo controlados via RdDM en este mutante, y no la consecuencia de los niveles de expresión de BIRl.

$B I R 1$ pertenece a la familia génica $B I R$, con cuatro miembros de los cuales BIR2 y BIR3 funcionan también como reguladores negativos de la inmunidad mediada por BAK1 (Halter et al., 2014; Imkampe et al., 2017). La sobreexpresión transgénica de BIR3 en Arabidopsis también produce fenotipos morfológicos dependientes de dosis (Imkampe et al., 2017). En un estudio previo, Arabidopsis transgénicas que expresaban BIRl bajo el promotor constitutivo $35 \mathrm{~S}$ mostraban una morfología y desarrollo normal y las respuestas PTI no estaban aparentemente afectadas, lo cual sugiere que el transgen BIRl se expresaba a niveles no deletéreos en esas condiciones experimentales (Liu et al., 2016).

\subsection{Modelo de regulación de BIR1}

En conclusión nuestros resultados demuestran que los virus de plantas inician una respuesta inmune basal que implica la activación dependiente de SA del represor inmune BIRl. BIRl actúa como un regulador negativo de la defensa antiviral en Arabidopsis. El mecanismo preciso de esta respuesta antiviral no ha podido ser precisado si bien parece ser independiente de la muerte celular y las defensas mediadas por SA y SOBIR1. Tanto la pérdida de función de BIRl como su sobreexpresión provocan procesos autoinmunes en la planta. Por ello, la regulación de BIRl dentro de un umbral de expresión óptimo es esencial para evitar la activación constitutiva de respuestas defensivas deletéreas para la planta. En este escenario, el silenciamiento por RNA porporciona dos barreras de regulación complementarias: la transcripcional y la post-transcripcional. Durante la infeccion, cuando BIRI se activa transcripcionalmente, ambas previenen, por sí mismas o en conjunto con otros mecanismos reguladores, la sobreacumulación de BIRl por encima de su umbral óptimo de expresión (Figura 4.3A y B). Con estos resultados desvelamos u mecanismo novedoso que regula la homeostasis de BIRl y que puede ser común a otros componentes de la inmunidad vegetal. 


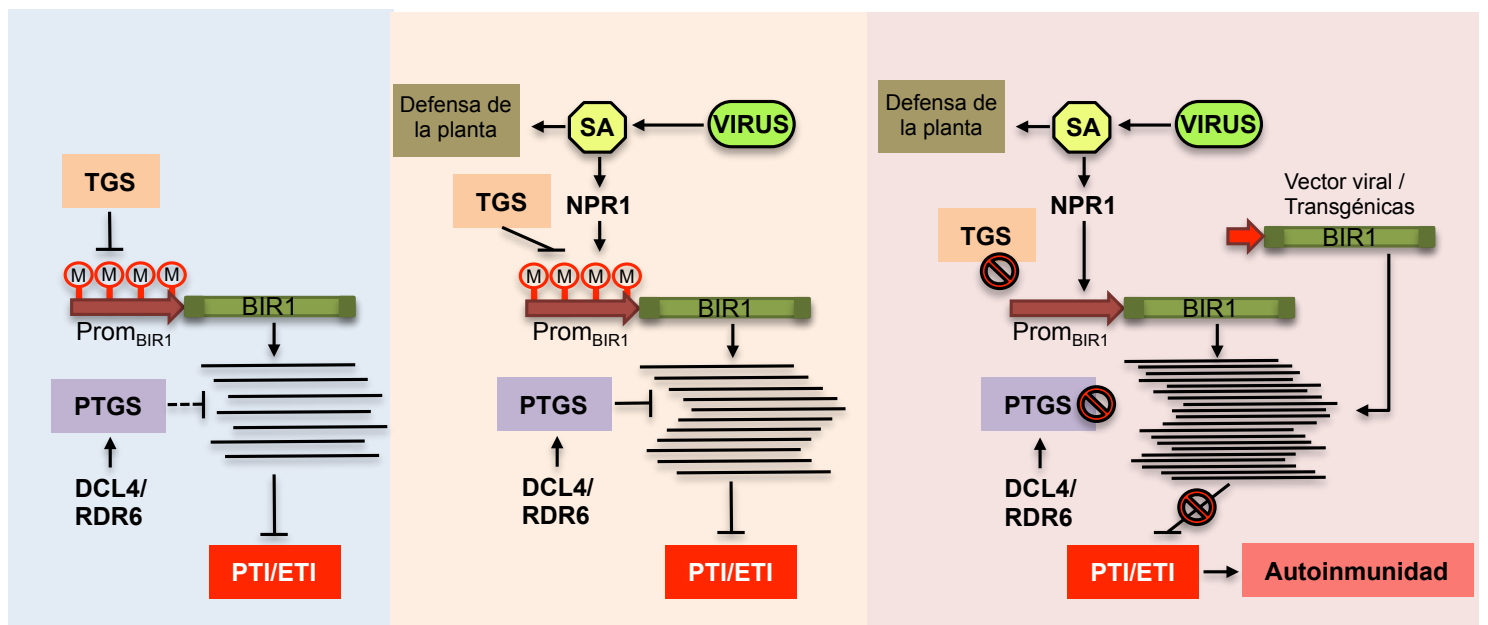

B

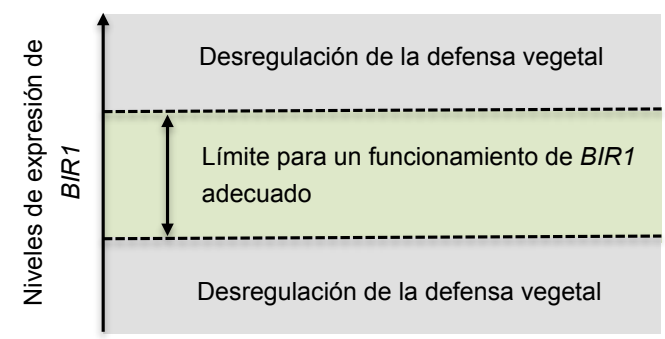

Figura 4.3. Modelo de regulación de BIR1. A) El silenciamiento génico transcripcional (TGS) y posttranscripcional (PTGS) cooperan, entre sí o en conjunto con otros mecanismos, para regular los niveles de expresión de BIRI tanto en ausencia de patógeno como en plantas infectadas con virus. Los virus de plantas inducen la acumulación de SA que activa la expresión de BIR1 de forma dependiente de NPR1 así como otras respuestas defensivas. La alteración del silenciamiento génico (TGS y PTGS) o la sobreexpresión transgénica de BIR1 provocan unos niveles de BIR1 en la planta que pueden comprometer funcionamiento y causar un fenotipo de autoinmunidad. B) Los niveles de expresión de BIR1 deben de mantenerse dentro de unos límites funcionales más allá de los cuales la inmunidad vegetal resulta afectada apareciendo graves problemas en el desarrollo y muerte celular.

\subsection{Inducción de genes $D I N$ y su efecto en la infección viral.}

En nuestro estudio hemos demostrado que TRV induce respuestas genéticas similares a las activadas durante la senescencia. La infección por TRV en Arabidopsis cursa en ausencia de manifestaciones morfológicas de enfermedad, por lo que la activación de los genes de senescencia ocurre de forma independiente al síndrome de senescencia. En conjunto, los genes DIN se activan en hojas senescentes, así como en hojas sometidas a estímulos que normalmente conducen a la senescencia, como la oscuridad, la carencia de fosfato o carbono, las heridas o el tratamiento con inhibidores de la fotosíntesis (Fujiki et al., 2001 1861). Los genes DIN también se regulan positivamente durante las respuestas incitadas por patógenos fúngicos y bacterianos, o durante el tratamiento con señales químicas inductoras de defensa (Schenk et al., 2005 
1848). Por lo tanto, parece razonable anticipar que los genes DIN son parte de las respuestas que utilizan las células para enfrentar el estrés que es común a la senescencia y a las infecciones por patógenos. En este contexto, la función de los genes $D I N$, como la de muchos otros genes inducibles por estrés, sigue siendo desconocida.

En esta tesis hemos estudiado el efecto de DIN1, DIN6 y DIN11 sobre la susceptibilidad de las plantas a la infección por virus. Nuestros resultados indican que estos tres genes se inducen en Arabidopsis en respuesta a TRV. Sus homólogos en $N$. benthamiana (NRIP1, ASN y DIN11) también se acumulan a niveles significativamente mayores en hojas infectadas con TRV o PVX, lo que sugiere que la inducción de genes $D I N$ probablemente representa una respuesta común a diferentes virus en diferentes especies hospedadoras (Fernandez-Calvino et al., 2016a). En N. benthamiana NRIP1, el homólogo de DIN1, se requiere para la resistencia mediada por el gen $N$ frente a TMV (Caplan et al., 2008; Fernandez-Calvino et al., 2016a). Sin embargo, nuestros datos indicaron que DIN1 es aparentemente irrelevante para la infección por virus en Arabidopsis. Esto concuerda con lo observado en infecciones con microbios bacterianos y fúngicos, aun cuando DIN1 se induce durante la defensa de Arabidopsis contra estos patógenos (Oh et al., 1996; Schenk et al., 2005). La pérdida de función de DIN6 tampoco tuvo una influencia relevante en la infección por TRV, al igual que lo observado durante la defensa basal y la resistencia contra la infección bacteriana y por oomycetos en Arabidopsis (Hwang et al., 2011). Por el contrario, la inactivación del homólogo de DIN6 en $N$. benthamiana sí que afecta de forma negativa la replicación de TRV y PVX en esta especie (Fernandez-Calvino et al., 2016a). Nuestros ensayos de infección en protoplastos de líneas RNAi frente a DIN11 mostraron niveles reducidos de acumulación de TRV, lo que sugiere que DIN11 contribuye a la susceptibilidad del virus en Arabidopsis en las etapas iniciales de la infección. Este fenotipo de resistencia no se correlaciona con la inducción de los genes de defensa $P R 1$ y $P D F 1.2$, aunque es posible que otros componentes de la respuesta inmune se activen en ausencia de DIN11 (Fernandez-Calvino et al., 2016a). Como alternativa, DIN11 pudiera actuar como factor proviral en la susceptibilidad viral facilitando la proliferación de TRV independientemente de la activación de las defensas. DIN11 codifica una proteína similar a las dioxigenasas de plantas que utilizan 2-oxoglutarato como cosustrato (Prescott and John, 1996; Fujiki et al., 2001). Por tanto, la inducción de DIN11 en plantas infectadas con virus podría estar relacionada con la desaminación de glutamato a 2-oxoglutarato por la enzima GDH, un componente de las respuestas de senescencia y defensa de las plantas que está regulado positivamente en plantas de Arabidopsis infectadas (Masclaux-Daubresse et al., 2006; Pageau et al., 2006; Fernandez-Calvino et al., 2014). Sin embargo, la función precisa de DIN11 y la manera en que su actividad influye en el desarrollo de la infección son aspectos aún desconocidos. 
5. CONCLUSIONES 



\section{CONCLUSIONES}

I. BIRl desempeña un papel importante en el control de las respuestas de defensas asociadas a la resistencia antiviral en Arabidopsis.

II. La expresión de BIRl está sujeta a una estricta regulación que garantiza un control apropiado de la respuesta inmune evitando la activación constitutiva de procesos autoinmunes.

Estas conclusiones se fundamentan en los siguientes hitos:

I. BIRl es un regulador negativo de la resistencia antiviral en Arabidopsis, que opera independientemente de la vía de defensa mediada por el ácido salicílico.

II. BIRl se activa a nivel transcripcional en respuesta a la infección viral por un mecanismo dependiente de ácido salicílico a través del receptor NPR1.

III. BIRl ha de regularse estrictamente dentro de unos límites funcionales óptimos que garanticen un control apropiado de la respuesta inmune y eviten la aparición de fenotipos autoinmunes.

IV. El silenciamiento génico constituye una matriz reguladora esencial en la homeostasis de BIR1, controlando su expresión a nivel transcripcional de forma constitutiva mediante la metilación de su secuencia promotora y a nivel post-transcripcional promoviendo la degradación de sus RNA mensajeros.

V. La regulación post-transcripcional de $B I R l$ es condicional e importante para eliminar el exceso de transcritos de BIRl producidos en respuesta a la infección.

VI. El procesamiento endonucleolítico de los RNAs mensajeros de BIRl es específico de secuencia y podría relacionarse con la actividad del miR5658 y/o con la formación de siRNAs asociados a la infección viral.

VII. DIN11 es un factor de susceptibilidad en Arabidopsis que facilita la proliferación viral en etapas tempranas de la infección. 

6. BIBLIOGRAFÍA 



\section{BIBLIOGRAFÍA}

Addo-Quaye, C., Miller, W., and Axtell, M.J. (2009). CleaveLand: a pipeline for using degradome data to find cleaved small RNA targets. Bioinformatics 25, 130-131.

Addo-Quaye, C., Eshoo, T.W., Bartel, D.P., and Axtell, M.J. (2008). Endogenous siRNA and miRNA targets identified by sequencing of the Arabidopsis degradome. Curr Biol 18, 758-762.

Adenot, X., Elmayan, T., Lauressergues, D., Boutet, S., Bouche, N., Gasciolli, V., and Vaucheret, H. (2006). DRB4-dependent TAS3 trans-acting siRNAs control leaf morphology through AGO7. Curr Biol 16, 927-932.

Allen, E., Xie, Z., Gustafson, A.M., and Carrington, J.C. (2005). microRNA-directed phasing during trans-acting siRNA biogenesis in plants. Cell 121, 207-221.

Allen, E., Xie, Z., Gustafson, A.M., Sung, G.H., Spatafora, J.W., and Carrington, J.C. (2004). Evolution of microRNA genes by inverted duplication of target gene sequences in Arabidopsis thaliana. Nat Genet 36, 1282-1290.

Asai, S., and Shirasu, K. (2015). Plant cells under siege: plant immune system versus pathogen effectors. Curr Opin Plant Biol 28, 1-8.

Asai, T., Tena, G., Plotnikova, J., Willmann, M.R., Chiu, W.L., Gomez-Gomez, L., Boller, T., Ausubel, F.M., and Sheen, J. (2002). MAP kinase signalling cascade in Arabidopsis innate immunity. Nature 415, 977-983.

Axtell, M.J., Jan, C., Rajagopalan, R., and Bartel, D.P. (2006). A two-hit trigger for siRNA biogenesis in plants. Cell 127, 565-577.

Baulcombe, D. (2004). RNA silencing in plants. Nature 431, 356-363.

Baumberger, N., and Baulcombe, D.C. (2005). Arabidopsis ARGONAUTE1 is an RNA Slicer that selectively recruits microRNAs and short interfering RNAs. Proc Natl Acad Sci U S A 102, 11928-11933.

Blevins, T., Rajeswaran, R., Shivaprasad, P.V., Beknazariants, D., Si-Ammour, A., Park, H.S., Vazquez, F., Robertson, D., Meins, F., Jr., Hohn, T., and Pooggin, M.M. (2006). Four plant Dicers mediate viral small RNA biogenesis and DNA virus induced silencing. Nucleic Acids Res 34, 6233-6246.

Boccara, M., Sarazin, A., Thiebeauld, O., Jay, F., Voinnet, O., Navarro, L., and Colot, V. (2014). The Arabidopsis miR472-RDR6 silencing pathway modulates PAMP- and effector-triggered immunity through the post-transcriptional control of disease resistance genes. PLoS Pathog 10, e1003883.

Bohmdorfer, G., Rowley, M.J., Kucinski, J., Zhu, Y., Amies, I., and Wierzbicki, A.T. (2014). RNA-directed DNA methylation requires stepwise binding of silencing factors to long non-coding RNA. Plant J 79, 181-191.

Bohmdorfer, G., Sethuraman, S., Rowley, M.J., Krzyszton, M., Rothi, M.H., Bouzit, L., and Wierzbicki, A.T. (2016). Long non-coding RNA produced by RNA polymerase $\mathrm{V}$ determines boundaries of heterochromatin. Elife $\mathbf{5}$.

Boller, T., and Felix, G. (2009). A renaissance of elicitors: perception of microbeassociated molecular patterns and danger signals by pattern-recognition receptors. Annu Rev Plant Biol 60, 379-406.

Bolouri Moghaddam, M.R., and Van den Ende, W. (2012). Sugars and plant innate immunity. J Exp Bot 63, 3989-3998.

Borges, F., and Martienssen, R.A. (2015). The expanding world of small RNAs in plants. Nat Rev Mol Cell Biol 16, 727-741. 
Borsani, O., Zhu, J., Verslues, P.E., Sunkar, R., and Zhu, J.K. (2005). Endogenous siRNAs derived from a pair of natural cis-antisense transcripts regulate salt tolerance in Arabidopsis. Cell 123, 1279-1291.

Bouche, N., Lauressergues, D., Gasciolli, V., and Vaucheret, H. (2006). An antagonistic function for Arabidopsis DCL2 in development and a new function for DCL4 in generating viral siRNAs. Embo J 25, 3347-3356.

Breen, S., Williams, S.J., Outram, M., Kobe, B., and Solomon, P.S. (2017). Emerging Insights into the Functions of Pathogenesis-Related Protein 1. Trends Plant Sci 22, 871-879.

Brodersen, P., and Voinnet, O. (2006). The diversity of RNA silencing pathways in plants. Trends Genet 22, 268-280.

Brodersen, P., Sakvarelidze-Achard, L., Bruun-Rasmussen, M., Dunoyer, P., Yamamoto, Y.Y., Sieburth, L., and Voinnet, O. (2008). Widespread translational inhibition by plant miRNAs and siRNAs. Science 320, 1185-1190.

Brosseau, C., El Oirdi, M., Adurogbangba, A., Ma, X., and Moffett, P. (2016). Antiviral Defense Involves AGO4 in an Arabidopsis-Potexvirus Interaction. Mol Plant Microbe Interact 29, 878-888.

Buchanan-Wollaston, V., Earl, S., Harrison, E., Mathas, E., Navabpour, S., Page, T., and Pink, D. (2003). The molecular analysis of leaf senescence--a genomics approach. Plant Biotechnol J 1, 3-22.

Buchanan-Wollaston, V., Page, T., Harrison, E., Breeze, E., Lim, P.O., Nam, H.G., Lin, J.F., Wu, S.H., Swidzinski, J., Ishizaki, K., and Leaver, C.J. (2005). Comparative transcriptome analysis reveals significant differences in gene expression and signalling pathways between developmental and dark/starvationinduced senescence in Arabidopsis. Plant J 42, 567-585.

Burgyan, J. (2008). Role of silencing suppressor proteins. Methods Mol Biol 451, 6979.

Burgyan, J., and Havelda, Z. (2011). Viral suppressors of RNA silencing. Trends Plant Sci 16, 265-272.

Butt, A., Mousley, C., Morris, K., Beynon, J., Can, C., Holub, E., Greenberg, J.T., and Buchanan-Wollaston, V. (1998). Differential expression of a senescenceenhanced metallothionein gene in Arabidopsis in response to isolates of Peronospora parasitica and Pseudomonas syringae. Plant J 16, 209-221.

Cao, M., Du, P., Wang, X., Yu, Y.Q., Qiu, Y.H., Li, W., Gal-On, A., Zhou, C., Li, Y., and Ding, S.W. (2014). Virus infection triggers widespread silencing of host genes by a distinct class of endogenous siRNAs in Arabidopsis. Proc Natl Acad Sci U S A 111, 14613-14618.

Cao, X., and Jacobsen, S.E. (2002). Role of the arabidopsis DRM methyltransferases in de novo DNA methylation and gene silencing. Curr Biol 12, 1138-1144.

Cao, X., Aufsatz, W., Zilberman, D., Mette, M.F., Huang, M.S., Matzke, M., and Jacobsen, S.E. (2003). Role of the DRM and CMT3 methyltransferases in RNA-directed DNA methylation. Curr Biol 13, 2212-2217.

Caplan, J.L., Mamillapalli, P., Burch-Smith, T.M., Czymmek, K., and DineshKumar, S.P. (2008). Chloroplastic protein NRIP1 mediates innate immune receptor recognition of a viral effector. Cell 132, 449-462.

Carbonell, A., and Carrington, J.C. (2015). Antiviral roles of plant ARGONAUTES. Curr Opin Plant Biol 27, 111-117.

Carbonell, A., Fahlgren, N., Mitchell, S., Cox, K.L., Jr., Mockler, T.C., and Carrington, J.C. (2015). Highly Specific Gene Silencing in a Monocot Species by Artificial MicroRNAs Derived From Chimeric MIRNA Precursors. Plant J. 
Carbonell, A., Fahlgren, N., Garcia-Ruiz, H., Gilbert, K.B., Montgomery, T.A., Nguyen, T., Cuperus, J.T., and Carrington, J.C. (2012). Functional analysis of three Arabidopsis ARGONAUTES using slicer-defective mutants. Plant Cell 24, 3613-3629.

Cerutti, H., and Casas-Mollano, J.A. (2006). On the origin and functions of RNAmediated silencing: from protists to man. Curr Genet 50, 81-99.

Chan, S.W., Henderson, I.R., Zhang, X., Shah, G., Chien, J.S., and Jacobsen, S.E. (2006). RNAi, DRD1, and histone methylation actively target developmentally important non-CG DNA methylation in arabidopsis. PLoS Genet 2, e83.

Chapman, E.J., and Carrington, J.C. (2007). Specialization and evolution of endogenous small RNA pathways. Nat Rev Genet 8, 884-896.

Chen, H.M., Chen, L.T., Patel, K., Li, Y.H., Baulcombe, D.C., and Wu, S.H. (2010). 22-Nucleotide RNAs trigger secondary siRNA biogenesis in plants. Proc Natl Acad Sci U S A 107, 15269-15274.

Chen, Z., Zheng, Z., Huang, J., Lai, Z., and Fan, B. (2009). Biosynthesis of salicylic acid in plants. Plant Signal Behav 4, 493-496.

Chinchilla, D., Shan, L., He, P., de Vries, S., and Kemmerling, B. (2009). One for all: the receptor-associated kinase BAK1. Trends Plant Sci 14, 535-541.

Chinchilla, D., Zipfel, C., Robatzek, S., Kemmerling, B., Nurnberger, T., Jones, J.D., Felix, G., and Boller, T. (2007). A flagellin-induced complex of the receptor FLS2 and BAK1 initiates plant defence. Nature 448, 497-500.

Chisholm, S.T., Mahajan, S.K., Whitham, S.A., Yamamoto, M.L., and Carrington, J.C. (2000). Cloning of the Arabidopsis RTM1 gene, which controls restriction of long-distance movement of tobacco etch virus. Proc Natl Acad Sci U S A 97, 489-494.

Chivasa, S., Murphy, A.M., Naylor, M., and Carr, J.P. (1997). Salicylic Acid Interferes with Tobacco Mosaic Virus Replication via a Novel Salicylhydroxamic Acid-Sensitive Mechanism. Plant Cell 9, 547-557.

Christie, M., Brosnan, C.A., Rothnagel, J.A., and Carroll, B.J. (2011). RNA decay and RNA silencing in plants: competition or collaboration? Front Plant Sci 2, 99.

Clough, S.J., and Bent, A.F. (1998). Floral dip: a simplified method for Agrobacterium-mediated transformation of Arabidopsis thaliana. Plant J 16, 735-743.

Coll, N.S., Epple, P., and Dangl, J.L. (2011). Programmed cell death in the plant immune system. Cell Death Differ 18, 1247-1256.

Creasey, K.M., Zhai, J., Borges, F., Van Ex, F., Regulski, M., Meyers, B.C., and Martienssen, R.A. (2014). miRNAs trigger widespread epigenetically activated siRNAs from transposons in Arabidopsis. Nature 508, 411-415.

Curaba, J., and Chen, X. (2008). Biochemical activities of Arabidopsis RNAdependent RNA polymerase 6. J Biol Chem 283, 3059-3066.

Dangl, J.L., and Jones, J.D. (2001). Plant pathogens and integrated defence responses to infection. Nature 411, 826-833.

de Ronde, D., Butterbach, P., and Kormelink, R. (2014). Dominant resistance against plant viruses. Front Plant Sci 5, 307.

Deleris, A., Gallego-Bartolome, J., Bao, J., Kasschau, K.D., Carrington, J.C., and Voinnet, O. (2006). Hierarchical action and inhibition of plant Dicer-like proteins in antiviral defense. Science 313, 68-71.

Ding, S.-W., and Voinnet, O. (2007). Antiviral immunity directed by small RNAs. Cell 130, 413-426. 
Ding, S.W. (2010). RNA-based antiviral immunity. Nat Rev Immunol 10, 632-644.

Dominguez-Ferreras, A., Kiss-Papp, M., Jehle, A.K., Felix, G., and Chinchilla, D. (2015). An Overdose of the Arabidopsis Coreceptor BRASSINOSTEROID INSENSITIVE1-ASSOCIATED RECEPTOR KINASE1 or Its Ectodomain Causes Autoimmunity in a SUPPRESSOR OF BIR1-1-Dependent Manner. Plant Physiol 168, 1106-1121.

Donaire, L., Pedrola, L., de la Rosa, R., and Llave, C. (2011). High-Throughput Sequencing of RNA Silencing-Associated Small RNAs in Olive (Olea europaea L.). PLoS ONE 6, e27916.

Donaire, L., Barajas, D., Martinez-Garcia, B., Martinez-Priego, L., Pagan, I., and Llave, C. (2008). Structural and genetic requirements for the biogenesis of tobacco rattle virus-derived small interfering RNAs. J Virol 82, 5167-5177.

Dowen, R.H., Pelizzola, M., Schmitz, R.J., Lister, R., Dowen, J.M., Nery, J.R., Dixon, J.E., and Ecker, J.R. (2012). Widespread dynamic DNA methylation in response to biotic stress. Proc Natl Acad Sci U S A 109, E2183-2191.

Duan, C.G., Zhang, H., Tang, K., Zhu, X., Qian, W., Hou, Y.J., Wang, B., Lang, Z., Zhao, Y., Wang, X., Wang, P., Zhou, J., Liang, G., Liu, N., Wang, C., and Zhu, J.K. (2015). Specific but interdependent functions for Arabidopsis AGO4 and AGO6 in RNA-directed DNA methylation. EMBO J 34, 581-592.

Dunoyer, P., and Voinnet, O. (2005). The complex interplay between plant viruses and host RNA-silencing pathways. Curr Opin Plant Biol 8, 415-423.

Dunoyer, P., Schott, G., Himber, C., Meyer, D., Takeda, A., Carrington, J.C., and Voinnet, O. (2010a). Small RNA duplexes function as mobile silencing signals between plant cells. Science 328, 912-916.

Dunoyer, P., Brosnan, C.A., Schott, G., Wang, Y., Jay, F., Alioua, A., Himber, C., and Voinnet, O. (2010b). An endogenous, systemic RNAi pathway in plants. Embo J 29, 1699-1712.

Durrant, W.E., and Dong, X. (2004). Systemic acquired resistance. Annu Rev Phytopathol 42, 185-209.

Eamens, A., Wang, M.B., Smith, N.A., and Waterhouse, P.M. (2008). RNA silencing in plants: yesterday, today, and tomorrow. Plant Physiol 147, 456-468.

Elbashir, S.M., Martinez, J., Patkaniowska, A., Lendeckel, W., and Tuschl, T. (2001). Functional anatomy of siRNAs for mediating efficient RNAi in Drosophila melanogaster embryo lysate. Embo J 20, 6877-6888.

Elena, S.F., Fraile, A., and Garcia-Arenal, F. (2014). Evolution and emergence of plant viruses. Adv Virus Res 88, 161-191.

Espinoza, C., Medina, C., Somerville, S., and Arce-Johnson, P. (2007). Senescenceassociated genes induced during compatible viral interactions with grapevine and Arabidopsis. J Exp Bot 58, 3197-3212.

Falk, A., Feys, B.J., Frost, L.N., Jones, J.D., Daniels, M.J., and Parker, J.E. (1999). EDS1, an essential component of $\mathrm{R}$ gene-mediated disease resistance in Arabidopsis has homology to eukaryotic lipases. Proc Natl Acad Sci U S A 96, 3292-3297.

Fang, X., and Qi, Y. (2016). RNAi in Plants: An Argonaute-Centered View. Plant Cell 28, 272-285.

Fei, Q., Li, P., Teng, C., and Meyers, B.C. (2015). Secondary siRNAs from Medicago NB-LRRs modulated via miRNA-target interactions and their abundances. Plant J 83, 451-465.

Fernandez-Calvino, L., Guzman-Benito, I., Del Toro, F.J., Donaire, L., CastroSanz, A.B., Ruiz-Ferrer, V., and Llave, C. (2016a). Activation of senescence- 
associated Dark-inducible (DIN) genes during infection contributes to enhanced susceptibility to plant viruses. Mol Plant Pathol 17, 3-15.

Fernandez-Calvino, L., Martinez-Priego, L., Szabo, E.Z., Guzman-Benito, I., Gonzalez, I., Canto, T., Lakatos, L., and Llave, C. (2016b). Tobacco rattle virus $16 \mathrm{~K}$ silencing suppressor binds ARGONAUTE 4 and inhibits formation of RNA silencing complexes. J Gen Virol 97, 246-257.

Fernandez-Calvino, L., Osorio, S., Hernandez, M.L., Hamada, I.B., Del Toro, F.J., Donaire, L., Yu, A., Bustos, R., Fernie, A.R., Martinez-Rivas, J.M., and Llave, C. (2014). Virus-Induced Alterations in Primary Metabolism Modulate Susceptibility to Tobacco rattle virus in Arabidopsis. Plant Physiol 166, 18211838.

Finnegan, E.J., and Dennis, E.S. (1993). Isolation and identification by sequence homology of a putative cytosine methyltransferase from Arabidopsis thaliana. Nucleic Acids Res 21, 2383-2388.

Finnegan, E.J., and Kovac, K.A. (2000). Plant DNA methyltransferases. Plant Mol Biol 43, 189-201.

Franco-Zorrilla, J.M., Lopez-Vidriero, I., Carrasco, J.L., Godoy, M., Vera, P., and Solano, R. (2014). DNA-binding specificities of plant transcription factors and their potential to define target genes. Proc Natl Acad Sci U S A 111, 2367-2372.

Franco-Zorrilla, J.M., Del Toro, F.J., Godoy, M., Pérez-Pérez, J., López-Vidriero, I., Oliveros, J.C., García-Casado, G., Llave, C., and Solano, R. (2009). Genome-wide identification of small RNA targets based on target enrichment and microarray hybridizations. Plant J 59, 840-850.

Fujiki, Y., Yoshikawa, Y., Sato, T., Inada, N., Ito, M., Nishida, I., and Watanabe, A. (2001). Dark-inducible genes from Arabidopsis thaliana are associated with leaf senescence and repressed by sugars. Physiol Plant 111, 345-352.

Fujiki, Y., Nakagawa, Y., Furumoto, T., Yoshida, S., Biswal, B., Ito, M., Watanabe, A., and Nishida, I. (2005). Response to darkness of late-responsive dark-inducible genes is positively regulated by leaf age and negatively regulated by calmodulin-antagonist-sensitive signalling in Arabidopsis thaliana. Plant Cell Physiol 46, 1741-1746.

Fukudome, A., and Fukuhara, T. (2017). Plant dicer-like proteins: double-stranded RNA-cleaving enzymes for small RNA biogenesis. J Plant Res 130, 33-44.

Gao, M., Liu, J., Bi, D., Zhang, Z., Cheng, F., Chen, S., and Zhang, Y. (2008). MEKK1, MKK1/MKK2 and MPK4 function together in a mitogen-activated protein kinase cascade to regulate innate immunity in plants. Cell Res 18, 11901198.

Gao, M., Wang, X., Wang, D., Xu, F., Ding, X., Zhang, Z., Bi, D., Cheng, Y.T., Chen, S., Li, X., and Zhang, Y. (2009). Regulation of cell death and innate immunity by two receptor-like kinases in Arabidopsis. Cell Host Microbe 6, 3444.

Garcia, J.A., and Pallas, V. (2015). Viral factors involved in plant pathogenesis. Curr Opin Virol 11, 21-30.

Garcia-Ruiz, H. (2018). Susceptibility Genes to Plant Viruses. Viruses 10.

Garcia-Ruiz, H., Takeda, A., Chapman, E.J., Sullivan, C.M., Fahlgren, N., Brempelis, K.J., and Carrington, J.C. (2010). Arabidopsis RNA-Dependent RNA Polymerases and Dicer-Like Proteins in Antiviral Defense and Small Interfering RNA Biogenesis during Turnip Mosaic Virus Infection. Plant Cell 22, 481-496. 
Garcia-Ruiz, H., Carbonell, A., Hoyer, J.S., Fahlgren, N., Gilbert, K.B., Takeda, A., Giampetruzzi, A., Garcia Ruiz, M.T., McGinn, M.G., Lowery, N., Martinez Baladejo, M.T., and Carrington, J.C. (2015). Roles and Programming of Arabidopsis ARGONAUTE Proteins during Turnip Mosaic Virus Infection. PLoS Pathog 11, e1004755.

Gepstein, S., Sabehi, G., Carp, M.J., Hajouj, T., Nesher, M.F., Yariv, I., Dor, C., and Bassani, M. (2003). Large-scale identification of leaf senescenceassociated genes. Plant J 36, 629-642.

German, M.A., Luo, S., Schroth, G., Meyers, B.C., and Green, P.J. (2009). Construction of Parallel Analysis of RNA Ends (PARE) libraries for the study of cleaved miRNA targets and the RNA degradome. Nat Protoc 4, 356-362.

German, M.A., Pillay, M., Jeong, D.H., Hetawal, A., Luo, S., Janardhanan, P., Kannan, V., Rymarquis, L.A., Nobuta, K., German, R., De Paoli, E., Lu, C., Schroth, G., Meyers, B.C., and Green, P.J. (2008). Global identification of microRNA-target RNA pairs by parallel analysis of RNA ends. Nat Biotechnol 26, 941-946.

Giner, A., Lakatos, L., Garcia-Chapa, M., Lopez-Moya, J.J., and Burgyan, J. (2010). Viral protein inhibits RISC activity by argonaute binding through conserved WG/GW motifs. PLoS Pathog 6, e1000996.

Gohlke, J., Scholz, C.J., Kneitz, S., Weber, D., Fuchs, J., Hedrich, R., and Deeken, R. (2013). DNA methylation mediated control of gene expression is critical for development of crown gall tumors. PLoS Genet 9, e1003267.

Gouveia, B.C., Calil, I.P., Machado, J.P., Santos, A.A., and Fontes, E.P. (2016). Immune Receptors and Co-receptors in Antiviral Innate Immunity in Plants. Front Microbiol 7, 2139.

Goytia, E., Fernandez-Calvino, L., Martinez-Garcia, B., Lopez-Abella, D., and Lopez-Moya, J.J. (2006). Production of plum pox virus HC-Pro functionally active for aphid transmission in a transient-expression system. J Gen Virol 87, 3413-3423.

Guevara-Morato, M.A., de Lacoba, M.G., Garcia-Luque, I., and Serra, M.T. (2010). Characterization of a pathogenesis-related protein 4 (PR-4) induced in Capsicum chinense L3 plants with dual RNase and DNase activities. J Exp Bot 61, 3259-3271.

Guo, Q., Liu, Q., Smith, N.A., Liang, G., and Wang, M.B. (2016). RNA Silencing in Plants: Mechanisms, Technologies and Applications in Horticultural Crops. Curr Genomics 17, 476-489.

Gururani, M.A., Venkatesh, J., Upadhyaya, C.P., Nookaraju, A., Pandey, S.K., and Park, S.W. (2012). Plant disease resistance genes: Current status and future directions. Physiological and Molecular Plant Pathology 78, 51-65.

Halter, T., Imkampe, J., Blaum, B.S., Stehle, T., and Kemmerling, B. (2014a). BIR2 affects complex formation of BAK1 with ligand binding receptors in plant defense. Plant Signal Behav 9.

Halter, T., Imkampe, J., Mazzotta, S., Wierzba, M., Postel, S., Bucherl, C., Kiefer, C., Stahl, M., Chinchilla, D., Wang, X., Nurnberger, T., Zipfel, C., Clouse, S., Borst, J.W., Boeren, S., de Vries, S.C., Tax, F., and Kemmerling, B. (2014b). The leucine-rich repeat receptor kinase BIR2 is a negative regulator of BAK1 in plant immunity. Curr Biol 24, 134-143.

Hamberg, M., Sanz, A., Rodriguez, M.J., Calvo, A.P., and Castresana, C. (2003). Activation of the fatty acid alpha-dioxygenase pathway during bacterial 
infection of tobacco leaves. Formation of oxylipins protecting against cell death. J Biol Chem 278, 51796-51805.

Hammond-Kosack, K.E., and Jones, J.D. (1997). Plant Disease Resistance Genes. Annu Rev Plant Physiol Plant Mol Biol 48, 575-607.

Harvey, J.J., Lewsey, M.G., Patel, K., Westwood, J., Heimstadt, S., Carr, J.P., and Baulcombe, D.C. (2011). An antiviral defense role of AGO2 in plants. PLoS ONE 6, e14639.

Havecker, E.R., Wallbridge, L.M., Hardcastle, T.J., Bush, M.S., Kelly, K.A., Dunn, R.M., Schwach, F., Doonan, J.H., and Baulcombe, D.C. (2010). The Arabidopsis RNA-Directed DNA Methylation Argonautes Functionally Diverge Based on Their Expression and Interaction with Target Loci. Plant Cell.

He, K., Gou, X., Yuan, T., Lin, H., Asami, T., Yoshida, S., Russell, S.D., and Li, J. (2007). BAK1 and BKK1 regulate brassinosteroid-dependent growth and brassinosteroid-independent cell-death pathways. Curr Biol 17, 1109-1115.

He, P., Shan, L., Lin, N.C., Martin, G.B., Kemmerling, B., Nurnberger, T., and Sheen, J. (2006). Specific bacterial suppressors of MAMP signaling upstream of MAPKKK in Arabidopsis innate immunity. Cell 125, 563-575.

He, X.J., Hsu, Y.F., Pontes, O., Zhu, J., Lu, J., Bressan, R.A., Pikaard, C., Wang, C.S., and Zhu, J.K. (2009). NRPD4, a protein related to the RPB4 subunit of RNA polymerase II, is a component of RNA polymerases IV and V and is required for RNA-directed DNA methylation. Genes Dev 23, 318-330.

Heaton, N.S., and Randall, G. (2011). Multifaceted roles for lipids in viral infection. Trends Microbiol 19, 368-375.

Heese, A., Hann, D.R., Gimenez-Ibanez, S., Jones, A.M., He, K., Li, J., Schroeder, J.I., Peck, S.C., and Rathjen, J.P. (2007). The receptor-like kinase SERK3/BAK1 is a central regulator of innate immunity in plants. Proc Natl Acad Sci U S A 104, 12217-12222.

Heinlein, M. (2015). Plant virus replication and movement. Virology 479-480, 657671.

Herbers, K., Takahata, Y., Melzer, M., Mock, H.P., Hajirezaei, M., and Sonnewald, U. (2000). Regulation of carbohydrate partitioning during the interaction of potato virus Y with tobacco. Mol Plant Pathol 1, 51-59.

Ho, S.N., Hunt, H.D., Horton, R.M., Pullen, J.K., and Pease, L.R. (1989). Sitedirected mutagenesis by overlap extension using the polymerase chain reaction. Gene 77, 51-59.

Hou, C.Y., Lee, W.C., Chou, H.C., Chen, A.P., Chou, S.J., and Chen, H.M. (2016). Global Analysis of Truncated RNA Ends Reveals New Insights into Ribosome Stalling in Plants. Plant Cell 28, 2398-2416.

Howell, M.D., Fahlgren, N., Chapman, E.J., Cumbie, J.S., Sullivan, C.M., Givan, S.A., Kasschau, K.D., and Carrington, J.C. (2007). Genome-Wide Analysis of the RNA-DEPENDENT RNA POLYMERASE6/DICER-LIKE4 Pathway in Arabidopsis Reveals Dependency on miRNA- and tasiRNA-Directed Targeting. Plant Cell 19, 926-942.

Hull, R., Covey, S.N., and Maule, A.J. (1987). Structure and replication of caulimovirus genomes. J Cell Sci Suppl 7, 213-229.

Hutvagner, G., and Simard, M.J. (2008). Argonaute proteins: key players in RNA silencing. Nat Rev Mol Cell Biol 9, 22-32.

Hwang, I.S., An, S.H., and Hwang, B.K. (2011). Pepper asparagine synthetase 1 (CaAS1) is required for plant nitrogen assimilation and defense responses to microbial pathogens. Plant J 67, 749-762. 
Imkampe, J., Halter, T., Huang, S., Schulze, S., Mazzotta, S., Schmidt, N., Manstretta, R., Postel, S., Wierzba, M., Yang, Y., van Dongen, W., Stahl, M., Zipfel, C., Goshe, M.B., Clouse, S., de Vries, S.C., Tax, F., Wang, X., and Kemmerling, B. (2017). The Arabidopsis Leucine-Rich Repeat Receptor Kinase BIR3 Negatively Regulates BAK1 Receptor Complex Formation and Stabilizes BAK1. Plant Cell 29, 2285-2303.

Ishihara, T., Sekine, K.T., Hase, S., Kanayama, Y., Seo, S., Ohashi, Y., Kusano, T., Shibata, D., Shah, J., and Takahashi, H. (2008). Overexpression of the Arabidopsis thaliana EDS5 gene enhances resistance to viruses. Plant biology 10, 451-461.

Jefferson, R.A., Kavanagh, T.A., and Bevan, M.W. (1987). GUS fusions: betaglucuronidase as a sensitive and versatile gene fusion marker in higher plants. EMBO J 6, 3901-3907.

Ji, L., Liu, X., Yan, J., Wang, W., Yumul, R.E., Kim, Y.J., Dinh, T.T., Liu, J., Cui, X., Zheng, B., Agarwal, M., Liu, C., Cao, X., Tang, G., and Chen, X. (2011). ARGONAUTE10 and ARGONAUTE1 regulate the termination of floral stem cells through two microRNAs in Arabidopsis. PLoS Genet 7, e1001358.

Jinek, M., and Doudna, J.A. (2009). A three-dimensional view of the molecular machinery of RNA interference. Nature 457, 405-412.

Jirage, D., Tootle, T.L., Reuber, T.L., Frost, L.N., Feys, B.J., Parker, J.E., Ausubel, F.M., and Glazebrook, J. (1999). Arabidopsis thaliana PAD4 encodes a lipaselike gene that is important for salicylic acid signaling. Proc Natl Acad Sci U S A 96, 13583-13588.

Johansen, L.K., and Carrington, J.C. (2001). Silencing on the spot. Induction and suppression of RNA silencing in the Agrobacterium-mediated transient expression system. Plant Physiol 126, 930-938.

Jones, J.D., and Dangl, J.L. (2006). The plant immune system. Nature 444, 323-329.

Jones, J.D., Shlumukov, L., Carland, F., English, J., Scofield, S.R., Bishop, G.J., and Harrison, K. (1992). Effective vectors for transformation, expression of heterologous genes, and assaying transposon excision in transgenic plants. Transgenic Res 1, 285-297.

Karimi, M., Inze, D., and Depicker, A. (2002). GATEWAY vectors for Agrobacterium-mediated plant transformation. Trends Plant Sci 7, 193-195.

Kasschau, K.D., Fahlgren, N., Chapman, E.J., Sullivan, C.M., Cumbie, J.S., Givan, S.A., and Carrington, J.C. (2007). Genome-Wide Profiling and Analysis of Arabidopsis siRNAs. PLoS Biol 5, e57.

Katiyar-Agarwal, S., Gao, S., Vivian-Smith, A., and Jin, H. (2007). A novel class of bacteria-induced small RNAs in Arabidopsis. Genes Dev 21, 3123-3134.

Katiyar-Agarwal, S., Morgan, R., Dahlbeck, D., Borsani, O., Villegas, A., Jr., Zhu, J.K., Staskawicz, B.J., and Jin, H. (2006). A pathogen-inducible endogenous siRNA in plant immunity. Proc Natl Acad Sci U S A 103, 18002-18007.

Kemmerling, B., and Nurnberger, T. (2008). Brassinosteroid-independent functions of the BRI1-associated kinase BAK1/SERK3. Plant Signal Behav 3, 116-118.

Kemmerling, B., Schwedt, A., Rodriguez, P., Mazzotta, S., Frank, M., Qamar, S.A., Mengiste, T., Betsuyaku, S., Parker, J.E., Mussig, C., Thomma, B.P., Albrecht, C., de Vries, S.C., Hirt, H., and Nurnberger, T. (2007). The BRI1associated kinase 1, BAK1, has a brassinolide-independent role in plant celldeath control. Curr Biol 17, 1116-1122.

Kim, V.N. (2008). Sorting out small RNAs. Cell 133, 25-26. 
Kinkema, M., Fan, W., and Dong, X. (2000). Nuclear localization of NPR1 is required for activation of PR gene expression. Plant Cell 12, 2339-2350.

Korner, C.J., Klauser, D., Niehl, A., Dominguez-Ferreras, A., Chinchilla, D., Boller, T., Heinlein, M., and Hann, D.R. (2013). The immunity regulator BAK1 contributes to resistance against diverse RNA viruses. Mol Plant Microbe Interact 26, 1271-1280.

Lahmy, S., Pontier, D., Bies-Etheve, N., Laudie, M., Feng, S., Jobet, E., Hale, C.J., Cooke, R., Hakimi, M.A., Angelov, D., Jacobsen, S.E., and Lagrange, T. (2016). Evidence for ARGONAUTE4-DNA interactions in RNA-directed DNA methylation in plants. Genes Dev 30, 2565-2570.

Lam, H.M., Peng, S.S., and Coruzzi, G.M. (1994). Metabolic regulation of the gene encoding glutamine-dependent asparagine synthetase in Arabidopsis thaliana. Plant Physiol 106, 1347-1357.

Law, J.A., and Jacobsen, S.E. (2010). Establishing, maintaining and modifying DNA methylation patterns in plants and animals. Nat Rev Genet 11, 204-220.

Leibman, D., Kravchik, M., Wolf, D., Haviv, S., Weissberg, M., Ophir, R., Paris, H.S., Palukaitis, P., Ding, S.W., Gaba, V., and Gal-On, A. (2018). Differential expression of cucumber RNA-dependent RNA polymerase 1 genes during antiviral defence and resistance. Mol Plant Pathol 19, 300-312.

Lellis, A.D., Kasschau, K.D., Whitham, S.A., and Carrington, J.C. (2002). Loss-ofsusceptibility mutants of Arabidopsis thaliana reveal an essential role for eIF(iso)4E during potyvirus infection. Curr Biol 12, 1046-1051.

Li, F., Pignatta, D., Bendix, C., Brunkard, J.O., Cohn, M.M., Tung, J., Sun, H., Kumar, P., and Baker, B. (2012). MicroRNA regulation of plant innate immune receptors. Proc Natl Acad Sci U S A 109, 1790-1795.

Li, H.W., Lucy, A.P., Guo, H.S., Li, W.X., Ji, L.H., Wong, S.M., and Ding, S.W. (1999). Strong host resistance targeted against a viral suppressor of the plant gene silencing defence mechanism. EMBO J 18, 2683-2691.

Li, J., Wen, J., Lease, K.A., Doke, J.T., Tax, F.E., and Walker, J.C. (2002). BAK1, an Arabidopsis LRR receptor-like protein kinase, interacts with BRI1 and modulates brassinosteroid signaling. Cell 110, 213-222.

Li, X., Kapos, P., and Zhang, Y. (2015). NLRs in plants. Curr Opin Immunol 32, 114121.

Li, Y., Zhang, Q., Zhang, J., Wu, L., Qi, Y., and Zhou, J.M. (2010). Identification of microRNAs involved in pathogen-associated molecular pattern-triggered plant innate immunity. Plant Physiol 152, 2222-2231.

Liebrand, T.W., van den Burg, H.A., and Joosten, M.H. (2014). Two for all: receptor-associated kinases SOBIR1 and BAK1. Trends Plant Sci 19, 123-132.

Lim, P.O., and Nam, H.G. (2005). The molecular and genetic control of leaf senescence and longevity in Arabidopsis. Curr Top Dev Biol 67, 49-83.

Lin, J.F., and Wu, S.H. (2004). Molecular events in senescing Arabidopsis leaves. Plant J 39, 612-628.

Lindroth, A.M., Cao, X., Jackson, J.P., Zilberman, D., McCallum, C.M., Henikoff, S., and Jacobsen, S.E. (2001). Requirement of CHROMOMETHYLASE3 for maintenance of CpXpG methylation. Science 292, 2077-2080.

Liu, Q., and Paroo, Z. (2010). Biochemical principles of small RNA pathways. Annu Rev Biochem 79, 295-319.

Liu, Q., Feng, Y., and Zhu, Z. (2009). Dicer-like (DCL) proteins in plants. Funct Integr Genomics 9, 277-286. 
Liu, W., Duttke, S.H., Hetzel, J., Groth, M., Feng, S., Gallego-Bartolome, J., Zhong, Z., Kuo, H.Y., Wang, Z., Zhai, J., Chory, J., and Jacobsen, S.E. (2018). RNA-directed DNA methylation involves co-transcriptional smallRNA-guided slicing of polymerase V transcripts in Arabidopsis. Nat Plants 4, 181-188.

Liu, Y., Schiff, M., Marathe, R., and Dinesh-Kumar, S.P. (2002). Tobacco Rar1, EDS1 and NPR1/NIM1 like genes are required for N-mediated resistance to tobacco mosaic virus. Plant J 30, 415-429.

Liu, Y., Huang, X., Li, M., He, P., and Zhang, Y. (2016). Loss-of-function of Arabidopsis receptor-like kinase BIR1 activates cell death and defense responses mediated by BAK1 and SOBIR1. New Phytol 212, 637-645.

Livak, K.J., and Schmittgen, T.D. (2001). Analysis of relative gene expression data using real-time quantitative PCR and the 2(-Delta Delta C(T)) Method. Methods 25, 402-408.

Llave, C. (2010). Virus-derived small interfering RNAs at the core of plant-virus interactions. Trends Plant Sci 15, 701-707.

Llave, C. (2016). Dynamic cross-talk between host primary metabolism and viruses during infections in plants. Curr Opin Virol 19, 50-55.

Llave, C., Xie, Z., Kasschau, K.D., and Carrington, J.C. (2002a). Cleavage of Scarecrow-like mRNA targets directed by a class of Arabidopsis miRNA. Science 297, 2053-2056.

Llave, C., Kasschau, K.D., Rector, M.A., and Carrington, J.C. (2002b). Endogenous and silencing-associated small RNAs in plants. Plant Cell 14, 1605-1619.

Loake, G., and Grant, M. (2007). Salicylic acid in plant defence--the players and protagonists. Curr Opin Plant Biol 10, 466-472.

Lopez, A., Ramirez, V., Garcia-Andrade, J., Flors, V., and Vera, P. (2011). The RNA silencing enzyme RNA polymerase $\mathrm{v}$ is required for plant immunity. PLoS Genet 7, e1002434.

Love, A.J., Yun, B.W., Laval, V., Loake, G.J., and Milner, J.J. (2005). Cauliflower mosaic virus, a compatible pathogen of Arabidopsis, engages three distinct defense-signaling pathways and activates rapid systemic generation of reactive oxygen species. Plant Physiol 139, 935-948.

Ma, C., Liu, Y., Bai, B., Han, Z., Tang, J., Zhang, H., Yaghmaiean, H., Zhang, Y., and Chai, J. (2017). Structural basis for BIR1-mediated negative regulation of plant immunity. Cell Res 27, 1521-1524.

Macho, A.P., and Zipfel, C. (2014). Plant PRRs and the activation of innate immune signaling. Mol Cell 54, 263-272.

MacRae, I.J., Zhou, K., and Doudna, J.A. (2007). Structural determinants of RNA recognition and cleavage by Dicer. Nat Struct Mol Biol 14, 934-940.

Macrae, I.J., Li, F., Zhou, K., Cande, W.Z., and Doudna, J.A. (2006). Structure of Dicer and mechanistic implications for RNAi. Cold Spring Harb Symp Quant Biol 71, 73-80.

Makeyev, E.V., and Bamford, D.H. (2002). Cellular RNA-dependent RNA polymerase involved in posttranscriptional gene silencing has two distinct activity modes. Mol Cell 10, 1417-1427.

Mallory, A., and Vaucheret, H. (2010). Form, function, and regulation of ARGONAUTE proteins. Plant Cell 22, 3879-3889.

Mandadi, K.K., and Scholthof, K.B. (2013). Plant immune responses against viruses: how does a virus cause disease? Plant Cell 25, 1489-1505. 
Margis, R., Fusaro, A.F., Smith, N.A., Curtin, S.J., Watson, J.M., Finnegan, E.J., and Waterhouse, P.M. (2006). The evolution and diversification of Dicers in plants. FEBS Lett 580, 2442-2450.

Marques-Bueno, M.D.M., Morao, A.K., Cayrel, A., Platre, M.P., Barberon, M., Caillieux, E., Colot, V., Jaillais, Y., Roudier, F., and Vert, G. (2016). A versatile Multisite Gateway-compatible promoter and transgenic line collection for cell type-specific functional genomics in Arabidopsis. Plant J 85, 320-333.

Martinez, G., Castellano, M., Tortosa, M., Pallas, V., and Gomez, G. (2014). A pathogenic non-coding RNA induces changes in dynamic DNA methylation of ribosomal RNA genes in host plants. Nucleic Acids Res 42, 1553-1562.

Martinez-Priego, L., Donaire, L., Barajas, D., and Llave, C. (2008). Silencing suppressor activity of the Tobacco rattle virus-encoded $16-\mathrm{kDa}$ protein and interference with endogenous small RNA-guided regulatory pathways. Virology 376, 346-356.

Masclaux, C., Valadier, M.H., Brugiere, N., Morot-Gaudry, J.F., and Hirel, B. (2000). Characterization of the sink/source transition in tobacco ( Nicotiana tabacum L.) shoots in relation to nitrogen management and leaf senescence. Planta 211, 510-518.

Masclaux-Daubresse, C., Reisdorf-Cren, M., Pageau, K., Lelandais, M., Grandjean, O., Kronenberger, J., Valadier, M.H., Feraud, M., Jouglet, T., and Suzuki, A. (2006). Glutamine synthetase-glutamate synthase pathway and glutamate dehydrogenase play distinct roles in the sink-source nitrogen cycle in tobacco. Plant Physiol 140, 444-456.

Matzke, M., Kanno, T., Huettel, B., Daxinger, L., and Matzke, A.J. (2007). Targets of RNA-directed DNA methylation. Curr Opin Plant Biol 10, 512-519.

Matzke, M., Kanno, T., Daxinger, L., Huettel, B., and Matzke, A.J. (2009). RNAmediated chromatin-based silencing in plants. Curr Opin Cell Biol 21, 367-376.

Matzke, M.A., and Mosher, R.A. (2014). RNA-directed DNA methylation: an epigenetic pathway of increasing complexity. Nat Rev Genet 15, 394-408.

Matzke, M.A., Kanno, T., and Matzke, A.J. (2015). RNA-Directed DNA Methylation: The Evolution of a Complex Epigenetic Pathway in Flowering Plants. Annu Rev Plant Biol 66, 243-267.

Maule, A., Leh, V., and Lederer, C. (2002). The dialogue between viruses and hosts in compatible interactions. Curr Opin Plant Biol 5, 279-284.

Mayers, C.N., Lee, K.C., Moore, C.A., Wong, S.M., and Carr, J.P. (2005). Salicylic acid-induced resistance to Cucumber mosaic virus in squash and Arabidopsis thaliana: contrasting mechanisms of induction and antiviral action. Mol Plant Microbe Interact 18, 428-434.

Medina-Rivera, A., Defrance, M., Sand, O., Herrmann, C., Castro-Mondragon, J.A., Delerce, J., Jaeger, S., Blanchet, C., Vincens, P., Caron, C., Staines, D.M., Contreras-Moreira, B., Artufel, M., Charbonnier-Khamvongsa, L., Hernandez, C., Thieffry, D., Thomas-Chollier, M., and van Helden, J. (2015). RSAT 2015: Regulatory Sequence Analysis Tools. Nucleic Acids Res 43, W50-56.

Meister, G. (2013). Argonaute proteins: functional insights and emerging roles. Nat Rev Genet 14, 447-459.

Meyers, B.C., Kozik, A., Griego, A., Kuang, H., and Michelmore, R.W. (2003). Genome-wide analysis of NBS-LRR-encoding genes in Arabidopsis. Plant Cell 15, 809-834. 
Meyers, B.C., Axtell, M.J., Bartel, B., Bartel, D.P., Baulcombe, D., Bowman, J.L., Cao, X., Carrington, J.C., Chen, X., Green, P.J., Griffiths-Jones, S., Jacobsen, S.E., Mallory, A.C., Martienssen, R.A., Poethig, R.S., Qi, Y., Vaucheret, H., Voinnet, O., Watanabe, Y., Weigel, D., and Zhu, J.-K. (2008). Criteria for annotation of plant MicroRNAs. Plant Cell 20, 3186-3190.

Mi, S., Cai, T., Hu, Y., Chen, Y., Hodges, E., Ni, F., Wu, L., Li, S., Zhou, H., Long, C., Chen, S., Hannon, G.J., and Qi, Y. (2008). Sorting of small RNAs into Arabidopsis argonaute complexes is directed by the $5^{\prime}$ terminal nucleotide. Cell 133, 116-127.

Mlotshwa, S., Pruss, G.J., and Vance, V. (2008). Small RNAs in viral infection and host defense. Trends Plant Sci 13, 375-382.

Moazed, D. (2009). Small RNAs in transcriptional gene silencing and genome defence. Nature 457, 413-420.

Moffett, P. (2009). Mechanisms of Recognition in Dominant R Gene Mediated Resistance. Advances in Virus Research 75, 1-33.

Moissiard, G., and Voinnet, O. (2006). RNA silencing of host transcripts by cauliflower mosaic virus requires coordinated action of the four Arabidopsis Dicer-like proteins. Proc Natl Acad Sci U S A 103, 19593-19598.

Molnar, A., Melnyk, C.W., Bassett, A., Hardcastle, T.J., Dunn, R., and Baulcombe, D.C. (2010). Small silencing RNAs in plants are mobile and direct epigenetic modification in recipient cells. Science 328, 872-875.

Montgomery, T.A., Howell, M.D., Cuperus, J.T., Li, D., Hansen, J.E., Alexander, A.L., Chapman, E.J., Fahlgren, N., Allen, E., and Carrington, J.C. (2008a). Specificity of ARGONAUTE7-miR390 interaction and dual functionality in TAS3 trans-acting siRNA formation. Cell 133, 128-141.

Montgomery, T.A., Yoo, S.J., Fahlgren, N., Gilbert, S.D., Howell, M.D., Sullivan, C.M., Alexander, A., Nguyen, G., Allen, E., Ahn, J.H., and Carrington, J.C. (2008b). AGO1-miR173 complex initiates phased siRNA formation in plants. Proc Natl Acad Sci U S A 105, 20055-20062.

Morel, J.B., Godon, C., Mourrain, P., Beclin, C., Boutet, S., Feuerbach, F., Proux, F., and Vaucheret, H. (2002). Fertile hypomorphic ARGONAUTE (ago1) mutants impaired in post-transcriptional gene silencing and virus resistance. Plant Cell 14, 629-639.

Mosher, R.A., Schwach, F., Studholme, D., and Baulcombe, D.C. (2008). PolIVb influences RNA-directed DNA methylation independently of its role in siRNA biogenesis. Proc Natl Acad Sci U S A 105, 3145-3150.

Nakahara, K.S., and Masuta, C. (2014). Interaction between viral RNA silencing suppressors and host factors in plant immunity. Curr Opin Plant Biol 20, 88-95.

Nam, K.H., and Li, J. (2002). BRI1/BAK1, a receptor kinase pair mediating brassinosteroid signaling. Cell 110, 203-212.

Navarro, L., Dunoyer, P., Jay, F., Arnold, B., Dharmasiri, N., Estelle, M., Voinnet, O., and Jones, J.D. (2006). A plant miRNA contributes to antibacterial resistance by repressing auxin signaling. Science 312, 436-439.

Nicaise, V., and Candresse, T. (2017). Plum pox virus capsid protein suppresses plant pathogen-associated molecular pattern (PAMP)-triggered immunity. Mol Plant Pathol 18, 878-886.

Nicaise, V., Roux, M., and Zipfel, C. (2009). Recent advances in PAMP-triggered immunity against bacteria: pattern recognition receptors watch over and raise the alarm. Plant Physiol 150, 1638-1647. 
Obregon, P., Martin, R., Sanz, A., and Castresana, C. (2001). Activation of defencerelated genes during senescence: a correlation between gene expression and cellular damage. Plant Mol Biol 46, 67-77.

Oh, S.A., Lee, S.Y., Chung, I.K., Lee, C.H., and Nam, H.G. (1996). A senescenceassociated gene of Arabidopsis thaliana is distinctively regulated during natural and artificially induced leaf senescence. Plant Mol Biol 30, 739-754.

Ouyang, S., Park, G., Atamian, H.S., Han, C.S., Stajich, J.E., Kaloshian, I., and Borkovich, K.A. (2014). MicroRNAs suppress NB domain genes in tomato that confer resistance to Fusarium oxysporum. PLoS Pathog 10, e1004464.

Overhoff, M., Alken, M., Far, R.K., Lemaitre, M., Lebleu, B., Sczakiel, G., and Robbins, I. (2005). Local RNA target structure influences siRNA efficacy: a systematic global analysis. J Mol Biol 348, 871-881.

Pageau, K., Reisdorf-Cren, M., Morot-Gaudry, J.F., and Masclaux-Daubresse, C. (2006). The two senescence-related markers, GS1 (cytosolic glutamine synthetase) and GDH (glutamate dehydrogenase), involved in nitrogen mobilization, are differentially regulated during pathogen attack and by stress hormones and reactive oxygen species in Nicotiana tabacum L. leaves. J Exp Bot 57, 547-557.

Park, C.J., Caddell, D.F., and Ronald, P.C. (2012). Protein phosphorylation in plant immunity: insights into the regulation of pattern recognition receptor-mediated signaling. Front Plant Sci 3, 177.

Park, M.Y., Wu, G., Gonzalez-Sulser, A., Vaucheret, H., and Poethig, R.S. (2005). Nuclear processing and export of microRNAs in Arabidopsis. Proc Natl Acad Sci U S A 102, 3691-3696.

Patterson, K., Molloy, L., Qu, W., and Clark, S. (2011). DNA methylation: bisulphite modification and analysis. J Vis Exp.

Pelechano, V., Wei, W., and Steinmetz, L.M. (2015). Widespread Co-translational RNA Decay Reveals Ribosome Dynamics. Cell 161, 1400-1412.

Pontier, D., Gan, S., Amasino, R.M., Roby, D., and Lam, E. (1999). Markers for hypersensitive response and senescence show distinct patterns of expression. Plant Mol Biol 39, 1243-1255.

Potter, S., Uknes, S., Lawton, K., Winter, A.M., Chandler, D., DiMaio, J., Novitzky, R., Ward, E., and Ryals, J. (1993). Regulation of a hevein-like gene in Arabidopsis. Mol Plant Microbe Interact 6, 680-685.

Prelich, G. (2012). Gene overexpression: uses, mechanisms, and interpretation. Genetics 190, 841-854.

Prescott, A.G., and John, P. (1996). DIOXYGENASES: Molecular Structure and Role in Plant Metabolism. Annu Rev Plant Physiol Plant Mol Biol 47, 245-271.

Qi, G., Chen, J., Chang, M., Chen, H., Hall, K., Korin, J., Liu, F., Wang, D., and Fu, Z.Q. (2018). Pandemonium Breaks Out: Disruption of Salicylic AcidMediated Defense by Plant Pathogens. Mol Plant 11, 1427-1439.

Qi, Y., Denli, A.M., and Hannon, G.J. (2005). Biochemical specialization within Arabidopsis RNA silencing pathways. Mol Cell 19, 421-428.

Qi, Y., He, X., Wang, X.J., Kohany, O., Jurka, J., and Hannon, G.J. (2006). Distinct catalytic and non-catalytic roles of ARGONAUTE4 in RNA-directed DNA methylation. Nature 443, 1008-1012.

Qu, F., Ye, X., and Morris, T.J. (2008). Arabidopsis DRB4, AGO1, AGO7, and RDR6 participate in a DCL4-initiated antiviral RNA silencing pathway negatively regulated by DCL1. Proc Natl Acad Sci U S A 105, 14732-14737. 
Quirino, B.F., Normanly, J., and Amasino, R.M. (1999). Diverse range of gene activity during Arabidopsis thaliana leaf senescence includes pathogenindependent induction of defense-related genes. Plant Mol Biol 40, 267-278.

Quirino, B.F., Reiter, W.D., and Amasino, R.D. (2001). One of two tandem Arabidopsis genes homologous to monosaccharide transporters is senescenceassociated. Plant Mol Biol 46, 447-457.

Quirino, B.F., Noh, Y.S., Himelblau, E., and Amasino, R.M. (2000). Molecular aspects of leaf senescence. Trends Plant Sci 5, 278-282.

Raja, P., Sanville, B.C., Buchmann, R.C., and Bisaro, D.M. (2008). Viral Genome Methylation as an Epigenetic Defense against Geminiviruses ,. J. Virol. 82, 8997-9007.

Rajagopalan, R., Vaucheret, H., Trejo, J., and Bartel, D.P. (2006). A diverse and evolutionarily fluid set of microRNAs in Arabidopsis thaliana. Genes Dev 20, 3407-3425.

Ramachandran, V., and Chen, X. (2008). Degradation of microRNAs by a family of exoribonucleases in Arabidopsis. Science 321, 1490-1492.

Ritzenthaler, C. (2005). Resistance to plant viruses: old issue, news answers? Curr Opin Biotechnol 16, 118-122.

Rodriguez, E., El Ghoul, H., Mundy, J., and Petersen, M. (2016). Making sense of plant autoimmunity and 'negative regulators'. FEBS J 283, 1385-1391.

Ruiz-Ferrer, V., and Voinnet, O. (2007). Viral suppression of RNA silencing: 2b wins the Golden Fleece by defeating Argonaute. Bioessays 29, 319-323.

Ruiz-Ferrer, V., and Voinnet, O. (2009). Roles of plant small RNAs in biotic stress responses. Annu Rev Plant Biol 60, 485-510.

Schenk, P.M., Kazan, K., Rusu, A.G., Manners, J.M., and Maclean, D.J. (2005). The SEN1 gene of Arabidopsis is regulated by signals that link plant defence responses and senescence. Plant Physiol Biochem 43, 997-1005.

Schiebel, W., Pelissier, T., Riedel, L., Thalmeir, S., Schiebel, R., Kempe, D., Lottspeich, F., Sänger, H.L., and Wassenegger, M. (1998). Isolation of an RNA-directed RNA polymerase-specific cDNA clone from tomato. Plant Cell 10, 2087-2101.

Schippers, J.H., Nunes-Nesi, A., Apetrei, R., Hille, J., Fernie, A.R., and Dijkwel, P.P. (2008). The Arabidopsis onset of leaf death5 mutation of quinolinate synthase affects nicotinamide adenine dinucleotide biosynthesis and causes early ageing. Plant Cell 20, 2909-2925.

Schwessinger, B., Roux, M., Kadota, Y., Ntoukakis, V., Sklenar, J., Jones, A., and Zipfel, C. (2011). Phosphorylation-dependent differential regulation of plant growth, cell death, and innate immunity by the regulatory receptor-like kinase BAK1. PLoS Genet 7, e1002046.

Shalitin, D., and Wolf, S. (2000). Cucumber mosaic virus infection affects sugar transport in melon plants. Plant Physiol 123, 597-604.

Shan, L., He, P., Li, J., Heese, A., Peck, S.C., Nurnberger, T., Martin, G.B., and Sheen, J. (2008). Bacterial effectors target the common signaling partner BAK1 to disrupt multiple MAMP receptor-signaling complexes and impede plant immunity. Cell Host Microbe 4, 17-27.

Shivaprasad, P.V., Chen, H.M., Patel, K., Bond, D.M., Santos, B.A., and Baulcombe, D.C. (2012). A microRNA superfamily regulates nucleotide binding site-leucine-rich repeats and other mRNAs. Plant Cell 24, 859-874.

Soosaar, J.L., Burch-Smith, T.M., and Dinesh-Kumar, S.P. (2005). Mechanisms of plant resistance to viruses. Nat Rev Microbiol 3, 789-798. 
Stael, S., Kmiecik, P., Willems, P., Van Der Kelen, K., Coll, N.S., Teige, M., and Van Breusegem, F. (2015). Plant innate immunity--sunny side up? Trends Plant Sci 20, 3-11.

Strange, R.N., and Scott, P.R. (2005). Plant disease: a threat to global food security. Annu Rev Phytopathol 43, 83-116.

Stroud, H., Greenberg, M.V., Feng, S., Bernatavichute, Y.V., and Jacobsen, S.E. (2013). Comprehensive analysis of silencing mutants reveals complex regulation of the Arabidopsis methylome. Cell 152, 352-364.

Stroud, H., Do, T., Du, J., Zhong, X., Feng, S., Johnson, L., Patel, D.J., and Jacobsen, S.E. (2014). Non-CG methylation patterns shape the epigenetic landscape in Arabidopsis. Nat Struct Mol Biol 21, 64-72.

Sun, T., Zhang, Q., Gao, M., and Zhang, Y. (2014). Regulation of SOBIR1 accumulation and activation of defense responses in bir1-1 by specific components of ER quality control. Plant J 77, 748-756.

Tateda, C., Zhang, Z., Shrestha, J., Jelenska, J., Chinchilla, D., and Greenberg, J.T. (2014). Salicylic acid regulates Arabidopsis microbial pattern receptor kinase levels and signaling. Plant Cell 26, 4171-4187.

Tena, G., Boudsocq, M., and Sheen, J. (2011). Protein kinase signaling networks in plant innate immunity. Curr Opin Plant Biol 14, 519-529.

Tolia, N.H., and Joshua-Tor, L. (2007). Slicer and the argonautes. Nat Chem Biol 3, 36-43.

Torres, M.A., and Dangl, J.L. (2005). Functions of the respiratory burst oxidase in biotic interactions, abiotic stress and development. Curr Opin Plant Biol 8, 397403.

Truniger, V., and Aranda, M.A. (2009). Recessive resistance to plant viruses. Adv Virus Res 75, 119-159.

Vallarino, J.G., and Osorio, S. (2016). Simultaneous Determination of Plant Hormones by GC-TOF-MS. Methods Mol Biol 1363, 229-237.

van Loon, L.C., Rep, M., and Pieterse, C.M. (2006). Significance of inducible defense-related proteins in infected plants. Annu Rev Phytopathol 44, 135-162.

Vaucheret, H. (2008). Plant ARGONAUTES. Trends Plant Sci 13, 350-358.

Vazquez, F., Vaucheret, H., Rajagopalan, R., Lepers, C., Gasciolli, V., Mallory, A.C., Hilbert, J.L., Bartel, D.P., and Crete, P. (2004). Endogenous transacting siRNAs regulate the accumulation of Arabidopsis mRNAs. Mol Cell 16, 69-79.

Voinnet, O. (2005). Induction and suppression of RNA silencing: insights from viral infections. Nat Rev Genet 6, 206-220.

Voinnet, O., Pinto, Y.M., and Baulcombe, D.C. (1999). Suppression of gene silencing: a general strategy used by diverse DNA and RNA viruses of plants. Proc Natl Acad Sci U S A 96, 14147-14152.

Walters, D.R. (2003). Polyamines and plant disease. Phytochemistry 64, 97-107.

Wang, B., Yang, X., Wang, Y., Xie, Y., and Zhou, X. (2018). Tomato Yellow Leaf Curl Virus V2 Interacts with Host Histone Deacetylase 6 To Suppress Methylation-Mediated Transcriptional Gene Silencing in Plants. J Virol 92.

Wang, H., Buckley, K.J., Yang, X., Buchmann, R.C., and Bisaro, D.M. (2005). Adenosine kinase inhibition and suppression of RNA silencing by geminivirus AL2 and L2 proteins. J Virol 79, 7410-7418.

Wang, L.Y., Lin, S.S., Hung, T.H., Li, T.K., Lin, N.C., and Shen, T.L. (2012). Multiple domains of the tobacco mosaic virus p126 protein can independently 
suppress local and systemic RNA silencing. Mol Plant Microbe Interact 25, 648657.

Wang, X.-B., Wu, Q., Ito, T., Cillo, F., Li, W.-X., Chen, X., Yu, J.-L., and Ding, S.W. (2010). RNAi-mediated viral immunity requires amplification of virusderived siRNAs in Arabidopsis thaliana. Proc Natl Acad Sci USA 107, 484-489.

Wassenegger, M., and Krczal, G. (2006). Nomenclature and functions of RNAdirected RNA polymerases. Trends Plant Sci 11, 142-151.

Weaver, L.M., Gan, S., Quirino, B., and Amasino, R.M. (1998). A comparison of the expression patterns of several senescence-associated genes in response to stress and hormone treatment. Plant Mol Biol 37, 455-469.

Weirauch, M.T., Yang, A., Albu, M., Cote, A.G., Montenegro-Montero, A., Drewe, P., Najafabadi, H.S., Lambert, S.A., Mann, I., Cook, K., Zheng, H., Goity, A., van Bakel, H., Lozano, J.C., Galli, M., Lewsey, M.G., Huang, E., Mukherjee, T., Chen, X., Reece-Hoyes, J.S., Govindarajan, S., Shaulsky, G., Walhout, A.J.M., Bouget, F.Y., Ratsch, G., Larrondo, L.F., Ecker, J.R., and Hughes, T.R. (2014). Determination and inference of eukaryotic transcription factor sequence specificity. Cell 158, 1431-1443.

Whitham, S.A., and Wang, Y. (2004). Roles for host factors in plant viral pathogenicity. Curr Opin Plant Biol 7, 365-371.

Whitham, S.A., Quan, S., Chang, H.S., Cooper, B., Estes, B., Zhu, T., Wang, X., and Hou, Y.M. (2003). Diverse RNA viruses elicit the expression of common sets of genes in susceptible Arabidopsis thaliana plants. Plant J 33, 271-283.

Wierzba, M.P., and Tax, F.E. (2016). An Allelic Series of bak1 Mutations Differentially Alter birl Cell Death, Immune Response, Growth, and Root Development Phenotypes in Arabidopsis thaliana. Genetics 202, 689-702.

Wierzbicki, A.T., Ream, T.S., Haag, J.R., and Pikaard, C.S. (2009). RNA polymerase V transcription guides ARGONAUTE4 to chromatin. Nat Genet 41, 630-634.

Wierzbicki, A.T., Cocklin, R., Mayampurath, A., Lister, R., Rowley, M.J., Gregory, B.D., Ecker, J.R., Tang, H., and Pikaard, C.S. (2012). Spatial and functional relationships among Pol V-associated loci, Pol IV-dependent siRNAs, and cytosine methylation in the Arabidopsis epigenome. Genes Dev 26, 18251836.

Wildermuth, M.C., Dewdney, J., Wu, G., and Ausubel, F.M. (2001). Isochorismate synthase is required to synthesize salicylic acid for plant defence. Nature 414, 562-565.

Willmann, M.R., Endres, M.W., Cook, R.T., and Gregory, B.D. (2011). The Functions of RNA-Dependent RNA Polymerases in Arabidopsis. Arabidopsis Book 9, e0146.

Wise, R.P., Moscou, M.J., Bogdanove, A.J., and Whitham, S.A. (2007). Transcript Profiling in Host-Pathogen Interactions. Annu Rev Phytopathol 45, 329-369.

Wu, G., Park, M.Y., Conway, S.R., Wang, J.W., Weigel, D., and Poethig, R.S. (2009). The sequential action of miR156 and miR172 regulates developmental timing in Arabidopsis. Cell 138, 750-759.

Wu, L., Zhou, H., Zhang, Q., Zhang, J., Ni, F., Liu, C., and Qi, Y. (2010). DNA methylation mediated by a microRNA pathway. Mol Cell 38, 465-475.

Wu, Y., Zhang, D., Chu, J.Y., Boyle, P., Wang, Y., Brindle, I.D., De Luca, V., and Despres, C. (2012). The Arabidopsis NPR1 protein is a receptor for the plant defense hormone salicylic acid. Cell Rep 1, 639-647. 
Xie, M., and Yu, B. (2015). siRNA-directed DNA Methylation in Plants. Curr Genomics 16, 23-31.

Xie, Z., and Qi, X. (2008). Diverse small RNA-directed silencing pathways in plants. Biochim Biophys Acta 1779, 720-724.

Xie, Z., Allen, E., Fahlgren, N., Calamar, A., Givan, S.A., and Carrington, J.C. (2005). Expression of Arabidopsis MIRNA Genes. Plant Physiol.

Xie, Z., Johansen, L.K., Gustafson, A.M., Kasschau, K.D., Lellis, A.D., Zilberman, D., Jacobsen, S.E., and Carrington, J.C. (2004). Genetic and functional diversification of small RNA pathways in plants. PLoS Biol 2, E104.

Yamasaki, T., and Cerutti, H. (2017). Cooperative processing of primary miRNAs by DUS16 and DCL3 in the unicellular green alga Chlamydomonas reinhardtii. Commun Integr Biol 10, e1280208.

Ye, R., Chen, Z., Lian, B., Rowley, M.J., Xia, N., Chai, J., Li, Y., He, X.J., Wierzbicki, A.T., and Qi, Y. (2016). A Dicer-Independent Route for Biogenesis of siRNAs that Direct DNA Methylation in Arabidopsis. Mol Cell 61, 222-235.

Yi, H., and Richards, E.J. (2007). A cluster of disease resistance genes in Arabidopsis is coordinately regulated by transcriptional activation and RNA silencing. Plant Cell 19, 2929-2939.

Yoo, S.D., Cho, Y.H., and Sheen, J. (2007). Arabidopsis mesophyll protoplasts: a versatile cell system for transient gene expression analysis. Nat Protoc 2, 15651572.

Yoshikawa, M. (2013). Biogenesis of trans-acting siRNAs, endogenous secondary siRNAs in plants. Genes Genet Syst 88, 77-84.

Yoshikawa, M., Peragine, A., Park, M.Y., and Poethig, R.S. (2005). A pathway for the biogenesis of trans-acting siRNAs in Arabidopsis. Genes Dev 19, 21642175.

Yu, A., Lepere, G., Jay, F., Wang, J., Bapaume, L., Wang, Y., Abraham, A.L., Penterman, J., Fischer, R.L., Voinnet, O., and Navarro, L. (2013). Dynamics and biological relevance of DNA demethylation in Arabidopsis antibacterial defense. Proc Natl Acad Sci U S A 110, 2389-2394.

Yu, D., Chen, C., and Chen, Z. (2001). Evidence for an important role of WRKY DNA binding proteins in the regulation of NPR1 gene expression. Plant Cell 13, 1527-1540.

Yu, X., Willmann, M.R., Anderson, S.J., and Gregory, B.D. (2016). Genome-Wide Mapping of Uncapped and Cleaved Transcripts Reveals a Role for the Nuclear mRNA Cap-Binding Complex in Cotranslational RNA Decay in Arabidopsis. Plant Cell 28, 2385-2397.

Zamore, P.D., Tuschl, T., Sharp, P.A., and Bartel, D.P. (2000). RNAi: doublestranded RNA directs the ATP-dependent cleavage of mRNA at 21 to 23 nucleotide intervals. Cell 101, 25-33.

Zemach, A., Kim, M.Y., Hsieh, P.H., Coleman-Derr, D., Eshed-Williams, L., Thao, K., Harmer, S.L., and Zilberman, D. (2013). The Arabidopsis nucleosome remodeler DDM1 allows DNA methyltransferases to access H1-containing heterochromatin. Cell 153, 193-205.

Zhai, J., Jeong, D.H., De Paoli, E., Park, S., Rosen, B.D., Li, Y., Gonzalez, A.J., Yan, Z., Kitto, S.L., Grusak, M.A., Jackson, S.A., Stacey, G., Cook, D.R., Green, P.J., Sherrier, D.J., and Meyers, B.C. (2011). MicroRNAs as master regulators of the plant NB-LRR defense gene family via the production of phased, trans-acting siRNAs. Genes Dev 25, 2540-2553. 
Zhang, W., Fraiture, M., Kolb, D., Loffelhardt, B., Desaki, Y., Boutrot, F.F., Tor, M., Zipfel, C., Gust, A.A., and Brunner, F. (2013). Arabidopsis receptor-like protein30 and receptor-like kinase suppressor of BIR1-1/EVERSHED mediate innate immunity to necrotrophic fungi. Plant Cell 25, 4227-4241.

Zheng, X., Zhu, J., Kapoor, A., and Zhu, J.K. (2007). Role of Arabidopsis AGO6 in siRNA accumulation, DNA methylation and transcriptional gene silencing. Embo J 26, 1691-1701.

Zhong, X., Hale, C.J., Law, J.A., Johnson, L.M., Feng, S., Tu, A., and Jacobsen, S.E. (2012). DDR complex facilitates global association of RNA polymerase V to promoters and evolutionarily young transposons. Nat Struct Mol Biol 19, 870-875.

Zhong, X., Du, J., Hale, C.J., Gallego-Bartolome, J., Feng, S., Vashisht, A.A., Chory, J., Wohlschlegel, J.A., Patel, D.J., and Jacobsen, S.E. (2014). Molecular mechanism of action of plant DRM de novo DNA methyltransferases. Cell 157, 1050-1060.

Zhu, H., Hu, F., Wang, R., Zhou, X., Sze, S.H., Liou, L.W., Barefoot, A., Dickman, M., and Zhang, X. (2011). Arabidopsis Argonaute10 specifically sequesters miR166/165 to regulate shoot apical meristem development. Cell 145, 242-256.

Zilberman, D., Cao, X., and Jacobsen, S.E. (2003). ARGONAUTE4 control of locusspecific siRNA accumulation and DNA and histone methylation. Science 299, 716-719.

Zimmermann, P., Hirsch-Hoffmann, M., Hennig, L., and Gruissem, W. (2004). GENEVESTIGATOR. Arabidopsis microarray database and analysis toolbox. Plant Physiol 136, 2621-2632.

Zipfel, C. (2009). Early molecular events in PAMP-triggered immunity. Curr Opin Plant Biol 12, 414-420.

Zvereva, A.S., and Pooggin, M.M. (2012). Silencing and innate immunity in plant defense against viral and non-viral pathogens. Viruses 4, 2578-2597. 
